UNIVERSIDAD AUTONOMA METROPOLITANA UNIDAD IZTAPALAPA

DIVISION DE CIENCIAS SOCIALES Y HUMANIDADES

DEPARTAMENTO DE ANTROPOLOGIA

\title{
RITUAL, IDENTIDAD Y PROCESOS ETNICOS ENTRE LOS NAHUAS DE LA SIERRA DE ZONGOLICA, VERACRUZ.
}

\author{
Maria Teresa Rodriguez López \\ Tesis de Doctorado en Ciencias Antropológicas
}

Director: Dr. Enzo Segre Malagoli

Asesor: Dr. Alan R. Sandstrom

Asesor: Dr. Carlos Garma Navarro

mat. 94351169

octubre de 2000. 
RITUAL, IDENTIDAD Y PROCESOS ETNICOS ENTRE LOS NAHUAS

DE LA SIERRA DE ZONGOLICA, VERACRUZ.

Introducción

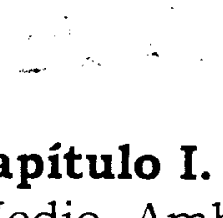

Integración Regional, Medio Ambiente y Apropiación del Territorio

\section{Capitulo II.}

El Sistema de Cargos y la Comunidad Indigena

\section{Capitulo III.}

El Calendario Festivo. Limites y Continuidades del Tiempo

Ritual 68

\section{Capitulo IV.}

Las Fiestas de Mayordomía: Reproducción de un Circuito Múltiple de Intercambios 108

\section{Capitulo V.}

El Universo de los Nahuas: Visión del Mundo y Procesos Sincréticos 148

\section{Capitulo VI.}

Ideologia Etnica, Mediaciones Culturales y Diversidad Religiosa

$$
\text { Comentarios Finales } 215
$$

Apéndice 


\section{AGRADECIMIENTOS.}

Durante el desarrollo de este trabajo conté con la cuidadosa asesoria del doctor Enzo Segre Malagoli, profesor del Departamento de Antropologia de la Universidad Autónoma Metropolitana, a quien agradezco sus valiosas aportaciones y su dedicación e interés permanentes.

Agradezco la lectura y comentarios al texto del Dr. Alan R. Sandstrom, profesor del Departamento de Antropologia de Indiana University-Purdue University y del Dr. Carlos Garma Navarro, profesor del Departamento de Antropología de la Universidad Autónoma Metropolitana.

Mi investigación se benefició asi mismo, de las condiciones y el ambiente de trabajo del CIESAS-Golfo, donde me desempeño como investigadora desde 1994. Recibi una beca del Consejo Nacional de Ciencia y Tecnologia de noviembre de 1994 a abril de 1999 y del Sistema Nacional de Investigadores a partir del mes de julio de 1998.

Por último, deseo expresar $\mathrm{mi}$ reconocimiento a las familias Ixmatlahua Montalvo y Hernández Ayohua, por su amistad y hospitalidad incondicionales durante mis estancias en la sierra de Zongolica. 


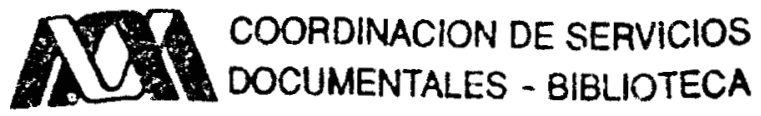

\section{INTRODUCCION.}

En este trabajo se abordan una serie de aspectos que han sido tema de controversia en la etnografia de México: el peso de las prácticas y simbolos rituales en los patrones de organización social de los pueblos indigenas de tradición mesoamericana. La cuestión resulta de interés si consideramos que los estudios etnográficos de varias décadas han interpretado a los sistemas de cargos como la estructura desde la cual se ha manifestado la especificidad de la comunidad indigena, propiciando sistemas de relaciones basados en formas de reciprocidad e integración jerárquica. Por otra parte, en trabajos recientes se ha reconocido que la comunidad indigena actual presenta una serie de contradicciones; en muchos casos se encuentra fragmentada y es inconsistente con la idea de la estabilidad y el equilibrio. No obstante, en las siguientes páginas planteo que el contexto del pueblo o comunidad indígena, como campo de relaciones, nos permite aún acercarnos a la realidad etnográfica del presente, a la complejidad de los procesos locales y regionales.

Se tocan aqui cuestiones relacionadas con los procesos de resistencia, persistencia y diferenciación en un municipio indígena con población de habla náhuatl. Mi objetivo ha sido elaborar una descripción etnográfica con un enfoque microscópico, a partir de observaciones, entrevistas abiertas y participación en un gran número de fiestas, eventos comunitarios y rutinas domésticas. Me interesaba indagar acerca de las formas en que ciertos elementos del sistema ceremonial de los nahuas son conservados, mientras otros se incorporan y otros más se excluyen, concibiendo el sistema local en palabras de Levi-Strauss (1964) como un conjunto de elecciones significativas. Consideré importante descubrir las pautas ideales del comportamiento ritual de los nahuas con el fin de poder lograr también una consideración dinámica de su sociedad actual, según el planteamiento de Leach (1976: 26) en el sentido de que "mientras que los modelos conceptuales de la sociedad son necesariamente modelos de los sistemas en equilibrio, las verdaderas sociedades no pueden estar en equilibrio".

Se presenta pues en las siguientes páginas una aproximación a la cosmovisión, ritualidad festiva y estructura social de un pueblo nahua de la sierra de Zongolica, porción de la Sierra Madre Oriental ubicada en el centro-oeste del estado de Veracruz. He elaborado una descripción del sistema de cargos religiosos bajo el cual se organiza el ciclo ceremonial de los nahuas; bajo el interés fundamental de relacionar tales prácticas con la lógica de la organización comunal en un contexto de profundas transformaciones regionales. Para ello, he intentado captar los sistemas de convenciones representados en las actividades y 
simbolos rituales del calendario ceremonial, a través de un registro empirico de las prácticas festivas y las formas en que se instituyen en la organización comunal. Considero que ésta puede ser una manera de acercarse a la comprensión del campo de las relaciones que se activan cuando estructuras de pequeña escala interactúan con estructuras de gran tamaño y se abre una contradicción entre la tradición y la innovación (Segre, 1994).

En el inicio de la investigación, partí de mis impresiones -producto de anteriores estancias entre los nahuas de la sierra de Zongolica- acerca de que las organizaciones locales basadas en el sistema de cargos religiosos continúan teniendo hoy en día un papel central en las dinámicas sociopoliticas de las localidades indigenas de la sierra. No obstante, mis inquietudes también incluian la consideración de que este sistema comenzaba a perder parte de sus alcances y atribuciones socioculturales, resultado de una serie de eventos que estaban en creciente contradicción con la ideologia de prestigio basada en la edad y en la distribución de bienes de consumo ritual. Me propuse, por lo tanto, entender hasta qué punto la realización de los rituales religiosos en torno al sistema de cargos continúa construyendo y reproduciendo el sentido comunitario entre los nahuas, considerando, como señala Adams (1995), que actualmente la mayoria de los grupos étnicos opera dentro de las presiones y bajo el impacto de acontecimientos que se generan a partir de los intereses globales de cada Estado-nación.

A partir de los años cincuenta del siglo $\mathrm{XX}$, se realizaron numerosos estudios que centraron su atención en el papel de las jerarquias civico religiosas y/o sistemas de cargos religiosos, en la reproducción social de la comunidad indigena de México y Centroamérica. A pesar de las diferencias en los enfoques e interpretaciones, se plantearon una serie de puntos en común, especialmente en cuanto a sus atribuciones en la delimitación de las fronteras comunitarias, en su capacidad para posibilitar la reproducción de la comunidad como unidad corporativa, reforzar la identidad local y constituir una fuente de prestigio individual. En sintesis, el estudio de esta institución dio lugar a que se le interpretara como el elemento que definia a la comunidad india (Cancian, 1989; Aguirre Beltrán, 1973; Dehouve, 1976; Wolf, 1986, entre otros).

No obstante, si partimos del hecho de que en el contexto actual es imposible sostener la concepción de la comunidad indigena como un espacio autónomo, aislado y estable, resulta de interés indagar si es congruente la interpretación de los sistema de cargos religiosos con los atributos arriba señalados. Mi hipótesis es que éste sistema, entre los nahuas contemporáneos, no representa el vehículo exclusivo en la definición de la comunidad y en el establecimiento de sus límites hacia el exterior, y que se manifiesta además, un decremento del poder y las funciones de los cargueros en la vida pública y politica. Por otra parte, me interesa también documentar cómo una estructura comunal coexiste en el seno 
de una sociedad clasista, asi como entender las formas en que las transformaciones culturales afectan directamente al comunalismo, partiendo de la hipótesis de que en Atlahuilco la realización del ciclo anual de fiestas ha constituido una forma de organización cuya dinámica ha permitido la interacción entre las distintas agrupaciones residenciales.

Si bien se ha señalado que el sistema de cargos representa un punto nodal en el mantenimiento de la identidades locales, mi interés en este trabajo es demostrar que ésta es una forma, pero no la única, por medio de la cual se mantiene el control sobre el espacio propio en momentos de agudas transformaciones sociales. Es decir, pretendo abordar el sistema de cargos implementado por los nahuas, más como un proceso que como una categoria, como lo sugieren Chance y Taylor (1987), y aportar información acerca de las maneras en que los sistemas de cargos se adecúan a distintos contextos espaciales y temporales. En este sentido, trato de argumentar que las interpretaciones que privilegiaron una posición -como sus funciones niveladoras, redistributivas o estratificadoras- no resultan útiles hoy en dia para explicar la complejidad del fenómeno. Desde esta perspectiva, mi intención es abordar la ritualidad festiva de los nahuas no como meras supervivencias de una institución que se ha mantenido a lo largo del tiempo, sino en su papel activo en la dinámica social, el cual es expresión de las relaciones y conflictos y se manifiesta en variados niveles de significación. Por ello, me detengo en tratar de señalar la relevancia del calendario ceremonial en la organización del espacio, en la adscripción territorial y en las identidades locales.

Dado que ninguna institución puede entenderse independientemente de su contexto histórico, regional y cultural, he tratado de aportar los elementos que enmarquen el escenario en el cual se desarrollan los eventos relativos a la vida ceremonial de los nahuas en el presente. Por otra parte, hago referencia a las concepciones que ligan su cosmovisión actual con una tradición que hunde sus raices en el pasado mesoamericano, puesto que las ideas y elementos que provenientes de los dos sistemas conceptuales -el cristiano y el nahua- se han influido reciprocamente. Ambos están presentes en las prácticas de los oficios, en los rituales agrarios y de purificación, y sus principios ordenan tanto el medio natural como el social.

Mi acercamiento a la región de Zongolica data de casi dos décadas, en el curso de las cuales he desarrollado interés hacia distintas temáticas. Ello me ha permitido apreciar transformaciones y continuidades en el modo de vida de los pueblos de la sierra y mantener relaciones de amistad con habitantes de diferentes puntos del área, a quienes me unen importantes experiencias personales como antropóloga de campo.

El material empirico aqui presentado corresponde básicamente al municipio de 
Atlahuilco, donde se manifiesta con vitalidad la transmisión del idioma náhuatl como lengua materna y el sistema de cargos religiosos como uno de los principales vehiculos para la organización social comunal. Se toma el municipio de Atlahuilco como un modelo etnográfico de estructura comunitaria para el resto de los pueblos de la parte alta de la Sierra de Zongolica, conocida localmente como "zona fria", considerando que la discusión en torno a los casos de localidades o poblaciones determinadas convierte a éstas en unidades operacionales en el estudio de la región entera, puesto que el fin es centrarse en el proceso más que en la dimensión sincrónica de la estructura comunitaria (Nutini y Bell, 1989).

Para este trabajo en particular, realicé temporadas de trabajo de campo entre 1995 y 1998, durante diferentes estaciones del año, en periodos de tres a seis semanas con la finalidad de presenciar la mayor parte del calendario ceremonial y laboral de los pobladores de Atlahuilco. Durante este tiempo residi principalmente en la cabecera del municipio, sin embargo, me desplazaba continuamente al resto de las localidades, especialmente en los casos en que se realizaban allí los rituales domésticos relacionados con las fiestas de mayordomia.

Me estableci en el seno de una familia bilingüe, residente de la cabecera municipal, participando de su posición estratégica en la localidad, producto de su competencia tanto en el ámbito cultural de los nahuas como en el mundo mestizo. Ello me permitió llevar a efecto mi trabajo de observación contando con su interpretación en los casos en que no alcanzaba a comprender determinados asuntos debido a mi limitado conocimiento del náhuatl, el cual consiste básicamente en cierto grado de competencia pasiva. No obstante, en la mayoria de los contextos, logré establecer comunicación verbal con los habitantes, dado que si bien la gran mayoria son nahuablantes, casi todos presentan algún grado de dominio del castellano.

En numerosas oportunidades pude asistir como parte de la comitiva familiar a distintos eventos en que se concertaban apadrinamientos, peticiones de mujeres, funerales, bodas y entrega o recibimiento de cargos religiosos a los que los miembros de la familia frecuentemente eran invitados. Sin embargo, no fue ésta la única vía de acercamiento a la vida ceremonial de los nahuas. Realicé también entrevistas dirigidas y continuas visitas a los funcionarios religiosos en turno y presencié por mi cuenta los elaborados preparativos para las fiestas y banquetes relacionados con la rotación de los cargos religiosos.

En todo momento conté con el apoyo de las autoridades civiles y religiosas, quienes se mostraron dispuestos a responder a mis preguntas y a proporcionar datos en los casos en que lo solicité. Dicha disposición habria sido de suma utilidad en caso de que se contara con un archivo municipal conformado por un 
acervo de cierta profundidad histórica, pero puesto que no fue éste el caso, mi reconstrucción de los acontecimientos que consideré relevantes para este trabajo se basan únicamente en entrevistas y en la lectura de otras fuentes de consulta.

Las interpretaciones aqui vertidas son producto también de mi acercamiento previo a la región, por lo tanto es dificil precisar el peso de mi experiencia anterior en las formulaciones que se generaron para la presentación de este texto en particular, si bien la mayor parte del material etnográfico relacionado con el sistema de cargos y el ciclo ceremonial data de mis observaciones más recientes. Especialmente en el apartado referente a las agrupaciones residenciales y la dinámica espacial del municipio, me apoyé en la información sistematizada para trabajos anteriores ${ }^{1}$, mismos que me permitieron establecer ciertas tendencias en relación al ciclo de desarrollo del grupo doméstico y la dinámica de las relaciones entre las distintas instancias municipales.

El alfabeto aplicado en este trabajo para la escritura de palabras en lengua náhuatl se basa en la propuesta desarrollada por el lingüista Andrés Hasler, investigador del CIESAS-Golfo, la cual es puesta en práctica por el Instituto Nacional de Educación para Adultos (INEA) y el Consejo Nacional de Fomento Educativo (CONAFE) en los materiales aplicados en la región de Zongolica. Esta propuesta es utilizada también en los cursos de esta lengua que se imparten en la Facultad de Antropologia de la Universidad Veracruzana y por la Iglesia Católica en la Diócesis de Orizaba. Sin embargo, en las citas referidas en el texto se respeta la ortografia utilizada por los autores.

\footnotetext{
Rodríguez, María Teresa. 1993. Grupos Domésticos y Organización Ceremonial en Atlahuilco, Veracruz. Xalapa. CIESAS-Golfo. (mcS.).

- 1995. "Estrategias de subsistencia y patrones residenciales: transformaciones en la organización doméstica de un pueblo nahua del centro de Veracruz", en: Romero y Jiménez (coords.), pp. 53-65.
} 


\section{CAPITULO I}

\section{INTEGRACION REGIONAL, MEDIO AMBIENTE Y APROPIACION DEL TERRITORIO.}

\section{a) El habitat serrano.}

El área ocupada por los nahuas de la sierra de Zongolica, se conforma por cuerpos de montañas que constituyen parte de la Sierra Madre Oriental. Los nahuas habitan en catorce municipios, todos de muy reducida extensión; ocupan en conjunto aproximadamente 980 kilómetros cuadrados. En el valle de Orizaba otros poblados nahuas, pertenecientes a los municipios de Rafael Delgado, Ixhuatlancillo, Tenejapa y Tlilapan evidencian que de antaño, la amplia zona del planialto veracruzano que conecta a las montañas de la Sierra Madre con las costas del Golfo, estuvo habitada por población de habla náhuatl.

La vertiente occidental de la sierra desemboca en el valle de Tehuacán, donde también se extiende una amplia franja de poblados en los cuales la vitalidad del idioma náhuatl se manifiesta en distintos grados. Sin embargo, es posible hablar de los nahuas de Zongolica, de forma más o menos especifica y sin temor a incurrir en una división artificial. Tanto la configuración ecológica del espacio, tan claramente contrastado, como una evidente unidad en patrones culturales, dialectales y de poblamiento, justifican de entrada esta delimitación, misma que ha sido aplicada por distintos investigadores.

La sierra de Zongolica se encuentra integrada por diversos paisajes naturales, en concordancia con un gradiente altitudinal que va de los 500 a los 2500 metros sobre el nivel del mar. Esta variación ambiental también se relaciona con la historia de uso del suelo que han implementado sus habitantes. Mientras que en algunas áreas de la parte alta de la sierra existen zonas boscosas, densamente pobladas de coniferas y encinales, en otras se encuentran amplios espacios afectados por el sistema de roza, tumba y quema y el pastoreo, aunque combinadas con manchones de bosque. En otras áreas, el paisaje se ha transformado en un páramo desforestado, utilizado en labores agricolas y ampliamente susceptible de erosión (Boege, 1991).

En las partes bajas de la sierra, cañadas, estrechos valles, nacimientos de agua, oquedades y barrancas conforman un paisaje húmedo y exuberante que permite un uso más diverso del suelo: milpas, frutales y cafetales reverdecen en torno a los poblados establecidos en el fondo de profundas pendientes o en las estribaciones de las elevaciones montañosas. En las partes altas, un entorno 
agroforestal, dispuesto en cordilleras y laderas, acoge conjuntos de viviendas dispersas, establecidas en los lomerios, elevaciones y pendiente, en coronados en invierno por una espesa y húmeda neblina.

Se accede a la sierra de Zongolica a través de una importante ruta carretera que comunica al Golfo de México con el altiplano central del pais. La autopista que atraviesa por el corredor industrial de la zona de Córdoba y Orizaba, en el centro del estado de Veracruz, sube hasta las cumbres de Maltrata, elevaciones vecinas de la serrania zongoliqueña. Una vez en la ciudad de Orizaba, el viajero se adentra a la sierra de Zongolica, por medio de un camino mal pavimentado, estrecho y empinado que asciende bordeando los cerros a lo largo de 38 kilómetros hasta la ciudad de Zongolica.

Los pueblos de la sierra se comunican entre si mediante una red de caminos de terraceria que fue iniciada hacia mediados de los años ochenta. Actualmente es posible llegar en vehiculo hasta todas las cabeceras municipales; al interior de cada municipio los habitantes se esfuerzan por conectar sus congregaciones y rancherias mediante caminos transitables, lo cual han logrado sólo parcialmente. Desde hace una década, la mayoria de los poblados nahuas han visto llegar la energia eléctrica alumbrando sus viviendas, y expandirse relativamente algunos servicios asistenciales y educativos.

Si bien la zona industrial de Córdoba-Orizaba constituye un importante polo de desarrollo en la franja central de Veracruz apenas se atravieza la línea imaginaria que separa el valle de Orizaba del ascenso a la serrania, se percibe un agudo contraste: el dinamismo de esta zona, la vida urbana y el intenso comercio desaparecen a unos cuantos kilómetros para dar cabida a una sucesión de poblados y rancherias dispersos en las montañas. Campos cultivados con la coa, que dejan al descubierto un suelo rocoso de delgada capa fértil, laderas humeantes por la quema, manchones de coniferas y bosque mesófilo de montaña, rodean las agrupaciones de viviendas de madera y pisos de tierra que en su mayoria componen los poblados nahuas. Pronto aparece el pueblo de Tequila, señalando el inicio del ascenso hacia la Cumbre de Reyes, el punto más alto de la ruta Orizaba-Zongolica. El pueblo de Zongolica aparecerá en una hoya rodeada de pronunciadas elevaciones -entre ellas el Acontécatl- que dan la impresión de encajonar a un apretado poblado que se extiende hasta donde le es posible, por las pendientes y cañadas que lo circundan. El trazo urbano de Zongolica contrasta notablemente con el resto de las cabeceras municipales serranas, en las cuales el asentamiento más congregado se reduce casi siempre a unos cuantos metros, donde se ubican las oficinas del ayuntamiento, el templo católico, las aulas escolares y algunos modestos establecimientos comerciales.

De la carretera Orizaba-Zongolica se desprenden otras rutas de acceso, más recientes y de dificil acceso que comunican a los municipios nahuas a partir de los pueblos de Tequila -hacia las partes más altas y frias en dirección suroeste- y 
de Zongolica, de donde se desprenden caminos que llevan hacia el sureste para atravesar la sierra y bajar por las cañadas que desembocan en las planicies cañeras de Tezonapa, vecinas a la sierra mazateca de Oaxaca. Esta zona se conoce localmente como la "tierra caliente", tlaletotonik, y recibe jornaleros de los pueblos de "la tierra fria", tlalesesekya, quienes, en las pendientes de la zona de transición se emplean en los cafetales, pero sobre todo, en las cálidas llanuras veracruzanas del centro del estado durante las temporadas de zafra.

El gradiente latitudinal genera una notable diversidad ambiental en un espacio geográfico relativamente reducido; en términos locales, esta diversidad da lugar a su clasificación en dos amplias categorias: "tierra fria", en la cual se inscriben la mayor parte de los municipios de la sierra, y "tierra caliente", que se refiere a casi todo el municipio de Zongolica y a una pequeña extensión de Mixtla y Texhuacan. En esta última se encuentran selvas medias subperennifolias, plantas de café sombreadas por frutales y árboles maderables y los cultivos asociados a la milpa (maiz, frijol y calabaza).

En los pueblos de las partes altas, los encinos (quercus crassifolias) proveen de leña para las cocinas y el consumo regional, y los ocotes (pinus patula) e ilites (cedronella mexicana) proporcionan los tablones para las viviendas y la materia prima para los carpinteros de Soledad Atzompa, Atlahuilco, Xoxocotla y Tlaquilpa. En estas áreas se practica una agricultura apenas para autoconsumo, con frugales cosechas anuales y en terrenos de extremo minifundismo. De ahi que los nahuas de la parte alta, se dediquen obligadamente a otras actividades además de la agricultura en sus propias parcelas: se emplean como jornaleros agricolas, aserradores, carpinteros, vendedores ambulantes, carboneros 0 empleados en la industria de la construcción.

Durante la mayor parte del año, la humedad permea el ambiente en toda la sierra, ya sea con los intensos y prolongados aguaceros de verano o bajo las espesas nieblas del otoño y el invierno. Sólo durante los meses de primavera, el sol reseca la tierra y los arroyos en espera de las lluvias de junio. Iniciada esta época, numerosos arroyos, manantiales y riachuelos atraviesan cumbres y pendientes. Ortiz (1991) identificó tres conjuntos de unidades ambientales, en la parte alta de la sierra, en las cuales se combina en distintos grados el uso del bosque con la agricultura de ladera, y en la cual existen incluso áreas totalmente desforestadas.

En la zona norte se localiza la más importante masa forestal y un tipo de agricultura en terrazas; esta área incluye territorios de los municipios de Soledad Atzompa, Tlaquilpa y Atlahuilco. El paisaje es accidentado, con depresiones profundas y altitudes que oscilan entre los 1500 y los 2400 metros sobre el nivel del mar. En cuanto al suelo, Ortiz señala que es de textura arcillosa y pobre en materia orgánica. Las precipitaciones pluviales son intensas a lo largo de todo el año; la temperatura promedio es de 17.6 grados centígrados, 
con inviernos rigurosos y veranos que no exceden los 22 grados centigrados (op. cit.: 14).

El uso del suelo se dedica a la explotación forestal, a las milpas combinadas con cultivos de invierno (haba, chicharo y lenteja), así como a algunos frutales para consumo local, principalmente ciruela y durazno; los rendimientos en los cultivos son pobres y no satisfacen las demandas de la población, en especial en cuanto al maiz se refiere.

El siguiente conjunto de unidades ambientales se compone de cerros y laderas amplias dispuestos en cordilleras y altitudes que varian de los 1800 a los 3200 metros sobre el nivel del mar. Las pronunciadas pendientes tienen suelos profundos, pobres en materia orgánica, de texturas que van de migajón arcilloso y migajón arcillo-arenoso. Este paisaje está compuesto por bosques de coniferas de las mismas especies mencionadas, pero con áreas totalmente desforestadas, en las que el manejo pecuario adquiere cierta importancia. En este mosaico se presenta mayor diversidad clmática; se localizan áreas húmedas, templadas subhúmedas y secas. La temperatura promedio anual oscila entre los 13.6 a los 17.4 grados centígrados, con un gradiente de humedad de mayor a menor en dirección este-oeste. Las precipitaciones pluviales van de los $1151.9 \mathrm{~mm}$. hasta los $723.7 \mathrm{~mm}$. con heladas en invierno (op.cit: 15). En esta área la agricultura de maiz y productos de invierno se combina con frutales caducifolios, con una producción de bajo rendimiento debido a la composición de los suelos. La cría de ovicaprinos y ganaderia de traspatio es frecuente en las áreas más desforestadas.

El tercer conjunto de unidades ambientales de la "tierra fria" de la sierra, se conforma por cerros altos y amplios, lomerios, hondonadas y barrancas profundas con altitudes de 1000 a 2400 metros sobre el nivel del mar. Según Ortiz (op.cit.: 13) los suelos son profundos, con un ph ácido, con texturas arcillosas y estructuras de bloques subangulares. La vegetación está conformada por un bosque de transición, compuesto por pinos y encinos; en este conjunto se encuentran también áreas totalmente desforestadas, especialmente en el municipio de Tehuipango y en una parte de Astacinga. Predomina aqui la actividad agricola con manejo de terrazas para el cultivo de maíz, cebada, lenteja y haba. La desforestación y pobreza de los suelos y el uso intensivo de los mismos, ha generado la existencia de áreas totalmente improductivas. La cria de ganado menor ha representado una alternativa ante las dificultades provocadas por la erosión y el uso inmoderado de los recursos forestales.

En sintesis, en relación al bosque, se encuentran en la sierra de Zongolica una diversidad de estadios sucesionales: masas densas de encinares en estado arbustivo, bosques de encino y pino en estado de maduración, acahuales y áreas totalmente desforestadas (la extensión más importante de bosque se localiza en los municipios de Soledad Atzompa, Atlahuilco y Tlaquilpa). EL cultivo de maiz 
en las laderas de la sierra, se realiza bajo el sistema de roza-tumba y quema; tecnologia que ha generado problemas ambientales debido a las necesidades de intensificación en su aplicación, abreviando los periodos de descanso y la rotación de las parcelas. (Boege, op. cit.: 50-58)

Estas caracteristicas ambientales, asi como las formas de aprovechamiento y acceso a los recursos, han dado lugar a la implementación de diversas estrategias de subsistencia por parte de los pobladores de la zona fria de la sierra: la agricultura de autoconsumo, asociada a la explotación del bosque para la producción de carbón, tablones y muebles rústicos, el trabajo a jornal en las plantaciones de los cañaverales de Córdoba y Tezonapa y en los cafetales de la región de Huatusco, en las planicies costeras y en la zona de transición de la franja central de la entidad veracruzana, y la ocupación en la industria de la construcción en el sector informal de las ciudades medias.

La sierra de Zongolica constituye una zona económicamente empobrecida; aun cuando existen estratificaciones y diversidades socioeconómicas, la mayoria de sus municipios son catalogados en situación de pobreza extrema; algunos de éstos -Tehuipango, Mixtla y Astacinga- ocupan los primeros lugares en cuanto al indice de marginalidad en todo el pais (CONAPO, 1993). De acuerdo a las cifras proporcionadas por el INEGI (1995), la población nahuahablante en la sierra, representa el 72.21 por ciento de la población total de los catorce municipios que integran la región.

Desde tiempos de la colonia, los pueblos de Tequila y Zongolica han sido puntos de intermediación de productos serranos, donde se han concentrado algunos capitales a partir del cultivo y comercialización del café, en Zongolica, y de la madera y el transporte público en Tequila. La ubicación de estos dos pueblos, al pie de la carretera que conduce a la ciudad de Orizaba, propició su consolidación como los lugares estratégicos para el mercadeo y el acaparamiento a nivel regional, asi como el surgimiento de grupos de poder local que durante décadas han influido en el comportamiento politico y económico de gran parte de la sierra.

Sin embargo, la reciente apertura de caminos y medios de transporte público que actualmente facilitan la comunicación de las cabeceras municipales con las ciudades de Orizaba, Córdoba y Ciudad Mendoza, está dando lugar a una paulatina pérdida de la importancia de los pueblos de Zongolica y Tequila como puntos neurálgicos en el desarrollo político y económico de la sierra. Los habitantes de los pueblos de la zona fria tienden ahora hacia una mayor autonomia en la toma de decisiones relacionadas con la comercialización de sus productos, en la gestión pública y en la búsqueda de las opciones más adecuadas para su propio beneficio. No obstante, Zongolica y Tequila continúan siendo puntos importantes como puertas de entrada al resto de los poblados serranos y como los lugares donde se concentra el núcleo más significativo de 
mestizos hispanohablantes, quienes son aún frecuentemente notables acaparadores y comerciantes.

Una nueva estratificación, acelerada por los cambios estructurales recientes por los que atraviesa la región, hace difícil hoy en dia presuponer una correspondencia entre diferencias socioeconómicas y oposiciones culturales: se encuentran tanto familias indígenas en ascenso económico como mestizos cuyo poder ha venido decayendo en los últimos lustros.

En los siguientes apartados de este capitulo me interesa señalar el proceso de conformación de la sierra de Zongolica como una región cuya configuración socioeconómica estuvo determinada por la dinámica colonial que inició con el arribo de los primeros españoles a las tierras serranas hacia mediados del siglo XVI. Planteo lo que considero los principales acontecimientos que dieron lugar a su conformación y composición actuales, a la luz de los datos disponibles. Parto del supuesto de que aún cuando las regiones son sistemas contingentes cuya organización y limites se renegocian constantemente, pueden ser suceptibles de representación (Hoffman y Salmerón, 1997: 17).

Tal y como sucedió en otras áreas de Mesoamérica, para los nahuas de Zongolica, las formas de apropiación de su entorno fueron profundamente influidas por la condición de subalternidad. La apropiación del espacio y la construcción del actual territorio de los nahuas, han sido procesos estrechamente ligados a la dinámica del orden colonial. Los habitantes de la sierra protagonizaron una lucha continua y prolongada por recuperar aquellas fracciones de su territorio que fueron apropiadas por los mercedados y hacendados españoles.

Considero relevante analizar bajo qué condiciones se han construido las lealtades y normas de acción colectivas que se afirman en los distintos ámbitos de pertenencia: el residencial, el comunitario y el regional, con el fin de abordar más adelante los aspectos relacionados con la organización contemporánea de los nahuas de Zongolica, estrechamente ligada a la actualización de un complejo ceremonial aún vigente.

\section{b) Los pobladores de Tzongoliuhcan y sus origenes ètnicos.}

De acuerdo a lo que se narra en la Historia Tolteca-Chichimeca, el grupo étnico nonoualca sojuzgó y dominó a la población asentada en la serrania de Zongolica a partir del siglo XII y hasta el siglo XVI. La Historia ToltecaChichimeca narra la invasión del Valle de Tehuacán y sus alrededores por el grupo étnico nonoalca-chichimeca, el cual sojuzgó a los pueblos ahí establecidos, fundando señoríos o cacicazgos que tres siglos más tarde cayeron vencidos por la Confederación Azteca. Según la traducción e interpretación de esta fuente, realizada por Kirchhoff, Odena y Reyes Garcia (1976), los nonoualca formaban 
parte de un pueblo mayor que junto con los tolteca se habia establecido en Tollan hacia el año 865 de nuestra era. Los tolteca mantenian subordinados a los nonoalca, quienes se mantenian como cazadores, recolectores y mercenarios, según la interpretación de Aguirre Beltrán acerca de este mismo documento. $(1986,20)$. Florescano (1997: 101) senala que al grupo tolteca- chichimeca que arribó a Tula procedente de las tierras norteñas, se unieron los nonoualca quienes estaban vinculados a la antigua cultura de Teotihuacan. La unión de estos grupos daria origen a la esplendorosa ciudad de Tula.

Esta idea de Florescano se contrapone con la posición de Aguirre Beltrán en el sentido de que los nonoualca procedian de un estadio cultural menos desarrollado y que por ello se mantuvieron subordinados a los tolteca; atribuye incluso la salida de los nonoualca de Tula a una exigencia de parte de los tolteca para que aquellos adquirieran el modo de vida sedentario. Florescano por su parte, afirma que según otra versión de la fundación de Tula basada en estudios arqueológicos recientes, en el siglo VIII las tribus norteñas de cazadores y recolectores invadieron las tierras fértiles aledañas al rio Lerma, donde encontraron a los nonoualca, vinculados al antiguo reino de Teotihuacan con quienes fundaron un nuevo estado. Es decir, en esta interpretación, los tolteca aparecen como los chichimecas cazadores recolectores que se integraron a una población de antigua tradición teotihuacana, los nonoualca.

Por mi parte, me adhiero a la posición de Aguirre Beltrán respecto a la procedencia y destino de los nonoualca, puesto que es acorde a lo que se narra en la Historia Tolteca-Chichimeca. Según esta fuente, los nonoualca se enemistaron con los tolteca, cuando un miembro de la nobleza tolteca, llamado Uemac, solicitó a los nonoalca le entregaran una mujer de caderas anchas, de una determinada medida. Aguirre Beltrán interpreta esta petición como una solicitud de parte de los tolteca para que los nonoualca abandonaran su rol de cazadores y asumieran la vida sedentaria de agricultores. La mujer de caderas anchas simboliza a la diosa de la tierra que rige las actividades ligadas a la agricultura (op. cit.: 40). Según la Historia Tolteca-Chichimeca, los nonoualca intentaron satisfacer esta demanda, pero la mujeres ofrecidas a Uemac fueron rechazadas reiteradamente por éste. De esta manera, se agudizó el conflicto entre los tolteca y sus subordinados nonoualca, quienes después de sacrificar a Uemac emprendieron su peregrinaje hacia el Este.

A la destrucción de Tollan, hacia el año 2 calli (en 1168), se habia consumado pues la separación de los tolteca y los nonoualca. Estos últimos peregrinaron en la búsqueda de un nuevo establecimiento, guiados por el tlatoani Xelhua y el tlamacazqui Atecatl, dirigiéndose al Valle de Tehuacán (op.cit.: 20-21). En este sitio se dividieron en tres subgrupos tribales para conquistar territorios en Cozcatlán, Teotitlán, Nanahuaticpac, Nextepec, Mazatlán, Tzoncoliuhcan y Tehuacán, donde establecieron cacicazgos y señorios sobre los pueblos ahi ubicados de antiguo: popolocas, mazatecas, chochos y posiblemente mixtecas. 
Imponen la lengua nahua, la cultura tolteca, sus deidades y sus formas de organización. En Tehuacán florece una ciudad comercial y se finca una actividad agricola altamente productiva, centro urbano que junto con Teotitlán, se configura en un próspero señorio cuyo poder declina hacia mediados del siglo $\mathrm{XV}$, cuando los guerreros mexicas dominan la región.

El lingüista Andrés Hasler (1996) plantea la hipótesis de que quizás antes de la llegada de los nonoualca se hablaba un dialecto nahua del este en algunas áreas de la región Tehuacán-Zongolica. Atribuye la variación dialectal entre los habitantes de la región a la sobreposición histórica de distintos dialectos nahuas: a) uno pre-nonoalca que corresponderia al nahua del este que llega a las costas del Golfo como lo señala Aguirre Beltrán, b) se impone después el nahua-nonoalca con el arribo de los nonoalca-chichimeca procedentes de Tula, c) y por último, el náhuatl de influencia tardia procedente del altiplano central en los tiempos de la dominación azteca, durante el periodo inmediatamente anterior a la conquista.

Según Aguirre Beltrán (1992) hacia principios del siglo XVI, se asentaban en Veracruz, pueblos de distinta formación lingüistica: del grupo yuto-azteca, del grupo macro-mayance y del grupo macro-otomangue. Los de lengua nahua tenian ya más de cinco siglos de habitar en el Bajo Papaloapan, mucho tiempo antes de que los mexicas ocuparan el Valle de México. Los nahuats que llegaron a la costa han sido identificados con los tolteca, los fundadores de Tula, quienes en su peregrinar llegaron hasta la costa del Golfo, pulverizándose en señorios numerosos y cuyo núcleo principal se habia establecido en los valles y eminencias de la sierra de Tuztla. Estos nahuats se diferenciaron de las tribus que llegaron más tarde a la meseta central; aunque pertenecieron al mismo tronco lingüistico, no usaban el fonema $\underline{\boldsymbol{t}}$ que caracterizó al náhuatl del altiplano central.

El autor señala que la tribu se dividió en Tula y una parte de ella emigró hasta Yucatán entre los siglos X y XI de nuestra era, de ahi que en todo el territorio entre Tula y el Mayab se encontraran islotes con población de habla nahua. La hoya del Papaloapan estaba unida con el Altiplano por el istmo Tzoncoliuhcan Ahuilizapan- Quauhtochco (Zongolica- Orizaba- Huatusco). Según el mito, Quetzalcoátl descendió en el Pico de Orizaba, muy cerca de la sierra de Zongolica (op.cit.: 12).

Las fuentes coloniales más antiguas referentes a la sierra de Zongolica, ubican a sus pobladores, los nonoalca-chichimeca- como hablantes de la lengua mexicana-nonoualca, implicando esta denominación un grado de variación dialectal con respecto al náhuatl del Altiplano. (Memoria de doctrinas de clérigos, 1565, cit. en Aguirre Beltrán, 1986: 33). Se supone pues que era nahuablante el grupo que arribó a este territorio ya ocupado, aunque no se sabe con certeza si era ésta su lengua original, o si fue adoptada del contacto con los 
tolteca. Aguirre Beltrán supone que los nonoualca-chichimeca sufrieron la pérdida del idioma antiguo y adquirieron el habla de los tolteca.

Hacia el siglo XVI, esta lengua se hablaba en distintos puntos de la vasta zona ocupada por los nonoualcas: el Valle de Puebla, la sierra de Zongolica, el Valle de Orizaba y las planicies de la zona de Córdoba-Omealca, en lugares como: Cozcatlán, Tehuacán, Zongolica, Cuetlaxca, Orizaba, Coscomatepec, Alpatlahua, Quimixtlán, Chichiquila, y Teoixhuacan. Aguirre Beltrản señala que la adopción de esta lengua por parte de los antiguos residentes de estos territorios siguió posiblemente un mismo patrón de politica lingüistica: el nahuatizar a los pueblos sometidos (op. cit.: 56). Este proceso de nahuatización, sin embargo, no fue homogéneo en toda la zon invadida por los nonoualca: en el señorio de Teotitlán, hacia el siglo XVI, la mayoria de sus pobladores aún hablaban el mazateca y sólo los dirigentes habian adoptado el náhuatl como lengua franca (aún hoy en dia, existen hablantes de mazateca en esta zona).

De manera que los grupos étnicos mazateca, popoloca, mixteca y otomi fueron los residentes de la sierra de Zongolica antes de ser sujetos por los nonoualca, donde los chalchiucalca-tzongoliuhque fundaron cacicazgos o señorios que posteriormente sucumbieron a la dominación azteca (op. cit.: 59). Como portadores de la cultura tolteca, los nonoualca no constituian ya simples bandas merodeadoras; estaban organizados como tribu, eran agricultores y se establecieron como señores de las poblaciones del valle de Tehuacán y de la sierra de Zongolica.

\section{c) Las mercedes y haciendas en la sierra de Zongolica.}

Según la interpretación de Aguirre Beltrán (1986) y Luis Reyes (1963), los pueblos de Zongolica y del Valle de Tehuacán ayudaron a la labor de conquista emprendida por Hernán Cortés, contribuyendo con guerreros al sitio y destrucción de la Gran Tenochtitlan. Los pipiltin, una vez acatada la dominación de los extranjeros, fueron ratificados en su estatus adscrito, al tiempo que se inició la asignación de encomenderos. Los pueblos de la Sierra de Zongolica habian quedado divididos en dos Repúblicas de Indios, cuyas cabeceras fueron los pueblos de Zongolica y Tequila.

Para Zongolica, fueron encomenderos Pedro de Sepúlveda, vecino de Puebla de los Angeles y su hija, mientras que Tequila aparece como pueblo sujeto a la Corona desde temprana época. Ambas Repúblicas pertenecieron a la alcaldía mayor de La Antigua Veracruz, integrando el partido de Zongolica. Su extensión correspondia a la misma del señorio o cacicato indígena prehispánico e incluia a los poblados serranos como sus estancias o pueblos sujetos. (Aguirre Beltrán, op. cit.: 22-61). Más tarde, algunos de éstos pasaron a ser también cabeceras de República de Naturales, como Astacinga (que fuera uno de los asientos principales de la pastoria que mantuvieron los jesuitas en la sierra de Zongolica) 
y Atlahuilco (formado por las estancias de Zacamilola y Quechulingo, hoy en día congregaciones del municipio de Atlahuilco).

Aguirre Beltrán apunta que quizás cada uno de los pueblos sujetos del partido de Zongolica, estaba dividido en tres barrios o calpultin, apoyándose en la evidencia de que en muchos pueblos de la sierra existe una organización por barrios; en algunos casos, como en Tehuipango, Mixtla y Reyes, la designación de los mismos conserva nombres como Mizcoatl, Ticoma y Tecpilpa, forma mítica de llamar a las tres piedras del fogón asociadas a deidades prehispánicas relacionadas con el dios del fuego (op. cit.: 69).

Aguirre Beltrán encontró datos relativos a las Repúblicas de Naturales de Tequila y Zongolica en fuentes de primera mano (1986). En el Libro de Tasaciones, en el que aparecen las actas de la Audiencia de México, se presentan las tasaciones impuestas a la República de Tequila de los años 1565 y 1570, asignadas a 406 tributarios residentes en sus siete estancias. En la Memoria de Doctrinas de Clérigos, se encuentra la lista de las estancias o pueblos sujetos que integraron a cada una de las dos Repúblicas de indios con cabecera en Tequila y Zongolica (a Zongolica correspondieron catorce estancias, mientras que a Tequila sólo ocho). La mayor parte de las estancias senaladas constituyen sitios identificables hoy en dia, aunque no siempre coinciden con los pueblos más importantes de la sierra. En algunos casos, dos o más estancias quedaron integradas en la posterior conformación municipal, como en el caso de Atzingo y Texhuacan que hoy pertenecen al municipio de Texhuacan; Atlanca y Los Reyes que quedaron como parte del territorio municipal de Los Reyes, y Zacamilola y Quechulingo que se ubican en lo que hoy es el municipio de Atlahuilco.

Para los años treinta del siglo XVI, los franciscanos incursionaron por primera vez en el Valle de Tehuacán y la Sierra de Zongolica, con la misión de evangelizar a la población indigena. Se establecieron en el pueblo de Zongolica, al que le dieron el nombre de San Francisco, santo patrono de su orden misionera, pero no fundaron ningún monasterio en el cacicazgo; decidieron hacerlo en Tehuacán, el cual quedó terminado hacia finales del siglo XVI (Aguirre Beltrán, op.cit.: 23). Los franciscanos fueron reemplazados por el clero secular en 1561, dependiente del obispado de Tlaxcala. Sin embargo, la difícil orografia de la Sierra impidió a los clérigos realizar una efectiva labor evangelizadora; se establecieron en los pueblos de Zongolica y Tequila, con escasas posibilidades de visitar con cierta frecuencia a las estancias o pueblos sujetos.

Hacia los últimos años del siglo XVI la Corona Española habia distribuido las tierras de Zongolica en mercedes reales, las cuales fueron dedicadas casi exclusivamente a la cria de especies menores. En 1592 se concedieron a vecinos de la ciudad de México veinte mercedes en las tierras serranas; las que quedaron, tres años después, en manos de Gil Avila de Montemayor. Al morir éste, en 1627, Juan del Castillo, por entonces alguacil mayor del pueblo y 
provincia de Tehuacán, compra dichas tierras y funda una hacienda de cabras en la sierra de Zongolica, la que donaria más tarde, en 1655, a la Sagrada Compañia de Jesús.

Durante prolongadas etapas del periodo colonial, los indigenas de la sierra de Zongolica lucharon por la recuperación de las tierras que se distribuyeron en mercedes reales desde temprana época. Se otorgaron veintitrés mercedes en distintos sitios que actualmente se ubican en los municipios de Tequila, Tlaquilpa, Texhuacan, Reyes, Zongolica, Atlahuilco y Tehuipango, mismas que serian cedidas más tarde a la Compañia de Jesús, institución que las administraria hasta antes de su expulsión en 1767. En el transcurso del periodo en que esta Compañia reguló la vida económica de la hacienda de cabras, la población indigena intentó la recuperación de sus tierras mediante litigios y demandas, lucha que continuaria hasta el siguiente siglo. Como resultado de sus movilizaciones, en 1713 los indios lograron que la Corona les devolviera sus tierras, pero sólo temporalmente: cuatro años después se le restituyen a la Compañia de Jesús, en cuyas manos permanecieron hasta 1767, año en que los jesuitas fueron expulsados de España y sus territorios conquistados.

Los jesuitas agregaron esta hacienda ganadera de la serrania zongoliqueña, a una de dimensiones mayores que tenia su matriz en el planialto poblano. Este complejo de hatos ganaderos, requeria de un buen número de pastores encargados de dirigir la trashumancia de cabras y ovejas entre cañadas y agostaderos. Dicho movimiento propició una apertura de rutas de comunicación entre el valle de Tehuacán, la Sierra de Zongolica, la Sierra Negra de Puebla y otros puntos, llegando incluso a conectarse con los estados de Oaxaca y Guerrero (Aguirre Beltrán, op. cit.: 208; Mouat, 1980).

Andrés Hasler (1996) sostiene que estos pastores introdujeron una variante del náhuatl procedente del occidente, distinta al nahuatl- nonoalca que se habla y se hablaba entonces en la serrania de Zongolica. Hasler ha detectado algunos puntos de la ruta Tehuacán-Zongolica donde aún se encuentra esta variante dialectal proveniente de los pastores. Los pastores fundaron ranchos en diversos puntos de la sierra, instalaciones sencillas destinadas a una permanencia temporal, en tanto los pastos reverdecian de nuevo en el planialto poblano. Los jesuitas fundaron dos pastorias en la zona fria de la sierra de Zongolica, en Xoxocotla y en Astacinga (hoy en dia cabeceras municipales) y otra más en la tierra templada, muy cerca del actual pueblo de Zongolica, en un sitio que aún se conoce como "La Compañia", espacio muy verde y bien provisto de agua.

En estos lugares, los pastores convivieron en términos de vecindad con los indios, quienes no tuvieron más remedio que aceptar el uso pastoril desconocido para ellos- que los mercedados daban a los terrenos aledaños a sus tierras recién reducidas y expropiadas. Aún cuando las autoridades coloniales alegaban otorgar mercedes en los terrenos no utilizados por los indios y que no 
les causaban perjuicios, en realidad se veia severamente restringido su acceso al entorno inmediato, a sus viviendas y campos de cultivo, impidiendo la utilización libre del territorio.

Una vez que los jesuitas se vieron obligados a abandonar sus posesiones, las ubicadas en la sierra de Zongolica fueron expropiadas por la Corona y vendidas al Marqués de Selva Nevada, terrateniente de Orizaba. A los pueblos indios se asignaron unicamente 600 varas del fundo legal para su establecimiento y se les prohibió enajenar dichas tierras. Se pretendia que con esta extensión -medida a los cuatro vientos a partir de la iglesia del pueblo- fuera suficiente para garantizar la sobrevivencia de los indios, sin embargo, una sola estancia de ganado mayor concedida a españoles cubria una legua cuadrada (Florescano, 1986: 43). En las tierras asignadas, los indios establecieron sus viviendas, sus solares y campos de cultivo individuales; reservaron casi siempre una extensión para uso colectivo, destinada al aprovisionamiento de leña, de materiales para construcción de las viviendas y de productos de recolección. Hasta hoy, algunos pueblos de la sierra de Zongolica, conservan este modelo de ocupación del espacio o reminiscencias muy claras del mismo.

Los funcionarios españoles que por entonces se aventuraban a incursionar por la serranía con la finalidad de conocer cómo vivian los pobladores a quienes cobraban tributos y se afanaban por congregar, encontraban que los indigenas, dispersos entre el monte y sus tierras de cultivo, tenian enormes dificultades para cultivar y cosechar en cañadas y terrenos rocosos, bajo condiciones de pobreza y carencia de alimentos. Los indios argumentaban la propiedad sobre los terrenos en disputa y además su imposibilidad de congregarse en las 600 varas que estipulaba la Corona. Ya entonces, a principios del siglo XVIII, gran parte de ellos emigraba de manera temporal o permanente hacia los trapiches de Córdoba, en la bocasierra, donde conseguian trabajo asalariado que ayudaba a mitigar un poco el hambre. (Aguirre Beltrán, op. cit.: 215).

Hacia fines del siglo XVIII, indios de la sierra disputaban incesantemente con los propietarios de la gran hacienda. En el Archivo Notarial de Orizaba y en el Archivo Municipal de Zongolica, Aguirre Beltrán encontró documentos que ilustran la contienda por la tierra que libraron los habitantes de Tequila, San Andrés Mixtla, San Juan Texhuacan y Los Reyes, argumentando que los marqueses de Selva Nevada habian usurpado tierras de su propiedad. Los indios de éstos y otros lugares fueron entonces notificados de su obligación de pagar arrendamiento por los terrenos concedidos para sus cultivos de maiz, o bien de agradecer se les permitiera el acceso a un terreno en el cual cultivar. Se les constriñe a ajustarse a las 600 varas que les corresponden, y a reconocer que la Marquesa de la Selva Nevada es la única y auténtica propietaria de sus tierras (Aguirre Beltrán, op. cit.: 232).

En la sierra de Zongolica, la politica de administración colonial fincada sobre la 
base de favorecer las mercedes y el desarrollo de las haciendas, se veria radicalmente transformada con el auge del cultivo del tabaco. En 1765 las autoridades coloniales establecieron que la sierra, así como las áreas circundantes del valle de Orizaba, integrarian el Real Estanco del Tabaco, zona restringida para el cultivo de este producto. Se alteró asi el sistema de la hacienda ganadera sostenida a través de las mercedes, para dar lugar a la entrada del tabaco, cultivo comercial que acabaria por introducir una forma de aprovechamiento basada en el modo de producción capitalista. (Aguirre Beltrán, op. cit.: 213).

Los cambios políticos en España a la invasión napoleónica y el posterior levantamiento de los criollos en la Nueva España, habrian de poner en compás de espera el prolongado litigio de los indios de la sierra de Zongolica en pos de la recuperación de sus tierras. Con el triunfo de la república, las condiciones se vuelven favorables a los indios, cuyo litigio interrumpido se retoma bajo la mirada de las ideas liberales. Para 1824 es propietario de la hacienda de cabras un teniente coronel llamado Aniceto José de Benavides, vecino del estado de Puebla. Aguirre Beltrán encuentra en el Archivo Municipal de Zongolica que cuando este propietario intenta introducir su ganado trashumante por Tlaquilpa rumbo a las pastorias de Astacinga, los indios provocaron la muerte de más de dos mil trescientas cabezas de ganado, actitud abiertamente beligerante ante los impedimentos para recuperar la posesión de sus tierras.

\section{d) El azúcar y el tabaco: la mano de obra indigena en los cultivos de las tierras templadas.}

Mientras todo aquello acontecia en el entorno serrano, en el valle de Orizaba, zona templada y pródiga en lluvias y humedad, se desencadenaban una serie de eventos que influirian decisivamente en la vida de los pueblos indios de la sierra. En el año 1542, el virrey Antonio de Mendoza fundó ahi un ingenio para la producción de azúcar; la humedad y ubicación de este lugar permitían una fecunda producción de caña, para cuyo procesamiento se requirió de la mano de obra de esclavos negros e indigenas.

Habitantes de los pueblos vecinos al valle de Orizaba, entre ellos Zongolica, acudian regularmente a trabajar en el ingenio, al igual que un contingente de esclavos negros. Es de este ingenio de donde escapa el famoso cimarrón Yanga, quien una vez libre, se estableció en la sierra de Zongolica para cometer desde ahi asaltos y correrias en la ruta México-Veracruz (Aguirre Beltrán, 1995: 23-27). Además del trabajo en el ingenio, indigenas nahuas de la sierra fueron obligados a colaborar en la construcción del convento de la concepción de Nuestra Señora en Tehuacán, el cual se concluyó en el año 1586 (Aguirre Beltrán, 1986: 23).

En 1690 se benefició a otro español como noble del Valle de Orizaba con el titulo de Marqués del Valle de la Colina, quien estableció potreros, molinos y criaderos 
de bestias de carga y de ganado vacuno. Este marquesado tendria que enfrentar durante sucesivos lustros, frecuentes litigios con terceros y con pueblos aledaños que reclamaban la posesión de determinadas extensiones que le habian sido asignadas. Los marqueses del Valle de la Colina impulsaron el cultivo de maiz y de tabaco; la producción, manufactura y distribución de tabaco se encontró entonces en asombroso auge e influyó considerablemente en el crecimiento y brillo de la ciudad de Orizaba, donde proliferaron entonces construcciones señoriales y expresiones de alcurnia entre la población criolla y española. (Aguirre Beltrán, op. cit.: 79)

En 1765 se designó a la región Córdoba -Orizaba, incluyendo las zonas de Huatusco y Zongolica, como el Real Estanco del Tabaco, es decir, el área restringida para la siembra de dicha planta. La Real Renta del Tabaco cerró entonces los establecimientos y campos de cultivo de este producto dispersos por la Nueva España para establecer centros fijos de manufactura en México, Orizaba y otras ciudades y privilegiar la región con la exclusividad de la siembra de tabaco.

Las tierras del piedemonte de la Sierra de Zongolica, fueron arrendadas a cosecheros de Orizaba para la siembra de tabaco, puesto que habian sido expropiadas por la Real Hacienda al ser expulsados los jesuitas que las usufructuaban, y aún no habian sido adquiridas por el marqués de la Selva Nevada. Los grandes propietarios de la zona tambiên fraccionaron sus tierras en ranchos para la siembra del tabaco, de modo que la serrania zongoliqueña y el Valle de Orizaba quedaron unidos mediante las fincas tabacaleras por un corredor agrícola y comercial. (Aguirre Beltrán, op.cit.: 83),

Los rancheros fueron los encargados de cuidar y mantener los cultivos de tabaco contratando jornaleros, en su mayoria indigenas de las localidades de la Sierra. Además de administrar y supervisar los cultivos, se encargaban de proporcionar la tierra, arrendándola a los nobles propietarios o a las comunidades indigenas. Aguirre Beltrán encuentra que en la zona de Orizaba estos rancheros eran mayoritariamente mestizos o pardos, mientras que en Córdoba eran mulatos. La clase noble asentada en las villas de Orizaba y Córdoba que permitió e impulsó el acaparamiento de las tierras de los indios por parte de los hacendados, cambiaria de posición en el momento en que se establece el Real Estanco del Tabaco, al inclinarse hacia esta manera fácil y rápida de acumular capital. Es entonces cuando el pueblo de Zongolica queda establecido como una villa donde se concentran además de indios, "gente de razón".

Al finalizar el siglo XIX se clausura el cultivo del tabaco. Otro aromático vendria a sustituir este cultivo comercial a fines del siglo XIX y principios del siglo XX en el piedemonte de la serranía zongoliqueña: el café. 


\section{e) Los pueblos de la sierra tras la disolución del régimen colonial.}

Al consumarse la independización de la Nueva España, la hacienda de cabras que abarcaba los municipios de las partes altas de la sierra, se encontraba en manos del coronel Aniceto José de Benavides, quien se vió obligado entonces a vender sus tierras a los ayuntamientos que integraron el cantón de Zongolica. Se instauraron los ilustres ayuntamientos y los alcaldes de Texhuacan, Zongolica, Mixtla, Coetzala, Tehuipango y Tlaquilpa, presentaron expedientes que los acreditaban con derecho a la posesión de determinadas extensiones de tierras. $\mathrm{El}$ coronel Benavides accede a venderlas bajo un convenio en el cual se establece que tendrá derecho al tránsito y pastos de su ganado. El convenio se firma el 27 de enero de 1824 según consta en el Archivo Municipal de Zongolica; en él se establece además que las tierras se venden a los pueblos de indios de acuerdo con las últimas leyes.

Se firma una escritura de compra-venta con los pueblos de Zongolica, Texhuacan, Reyes, Mixtla y Coetzala, cuya extensión total se valúa en 12 mil pesos que le son liquidados al teniente Benavides. De este modo, apenas instaurada la república, en 1824, los habitantes de Texhuacan, Zongolica, Reyes y Mixtla, adquieren las escrituras que legitiman su propiedad. Magdalena, Atlahuilco, Tlaquilpa, Tenejapa, Astacinga, Tehuipango y Atzompa lo hacen más tarde, al comprar a la heredera del coronel Benavides en 1848. Autoridades municipales de algunos de estos ayuntamientos conservan los documentos originales de esta transacción, entre ellos Atlahuilco, Texhuacan y Astacinga.

A partir de entonces se implementa un tipo de acceso a la tierra que permite que todo jefe de familia disponga de una fracción de terreno para construir su vivienda y para cultivar lo necesario para la manutención de su grupo familiar. Se estableció la cooperación de siete pesos por cada jefe de familia, con derecho a tres fanegas de tierras útiles y seis en los parajes lejanos. Si alguien deseaba adquirir una extensión mayor podia hacerlo cubriendo la tarifa estipulada por el ayuntamiento. A medida que se formaban nuevas familias, éstas podian solicitar al ayuntamiento la extensión para su solar y adquirir terrenos para su cultivo, tomados de una porción reservada para estos fines y para usos de beneficio colectivo.

Mientras que las haciendas de las partes bajas y templadas de la sierra se fraccionaban en terrenos ejidales, con el paso del tiempo, la parte alta quedó distribuida en minifundios de propiedad privada; cada jefe de familia adquirió terrenos de acuerdo a sus posibilidades y en algunos lugares ello propició la concentración de amplios territorios.

Hacia finales del siglo XIX la introducción del café transformaria la dinámica económica de las pueblos de la sierra. En las primeras décadas del siglo XX se habia convertido en el cultivo principal para los habitantes de las cañadas y 
zonas bajas y templadas ubicadas en altitudes de entre los 500 y los 1500 metros sobre el nivel del mar, en territorios de los municipios de Zongolica, Mixtla, Texhuacan, Los Reyes y Magdalena.

El proceso de privatización de la tierra después de instaurada la República, desencadenó el acaparamiento de las mejores tierras, especialmente en las zonas templadas, cuyas condiciones fisicas permitian un aprovechamiento agricola redituable. En los pueblos de las partes altas sus habitantes dedicaron sus terrenos a la milpa, en condiciones sumamente desventajosas en términos de tecnologia y condiciones del suelo. Gran parte de estos campesinos pobres, comenzaron entonces a emplearse en las plantaciones de café administradas por mestizos que establecieron haciendas en las barrancas, pequeños valles y cañadas como las de Xochitla y Coyametla. Hacia 1850 existian 23 haciendas en manos de mestizos, casi todas en las áreas templadas y cálidas de la sierra; a finales del siglo XIX la mayoria de ellas se dedicaba ya al cultivo del café. (Early, 1982: 49). A la par que la demanda de este aromático crecia en los Estados Unidos, se iniciaba en México un desarrollo capitalista impulsado por Porfirio Diaz a través del apoyo a compañias extranjeras. No faltaron norteamericanos que invirtieron en Zongolica adquiriendo maquinaria y estableciendo beneficios del grano de manera más eficiente y rápida que mediante la tecnologia rudimentaria del mortero.

Al triunfo de la Revolución Mexicana, el 80 por ciento de los campesinos del municipio de Zongolica carecía de tierras, mientras que el 3 por ciento poseía el 80 por ciento de las propiedades (Early, op. cit.: 54-59). La Reforma Agraria expropió las grandes haciendas de la región y las empresas con capital extranjero, y en su lugar se establecieron ejidos y pequeñas propiedades minifundistas. La mayoria de los ejidos se establecieron en la tierra templada que corresponde hoy al municipio de Zongolica, donde habia proliferado el cultivo del café; si bien estos ejidos quedaron en manos de campesinos indigenas, se habia establecido ahi un sector de población mestiza en la región, el que arribó a la par que el cultivo del tabaco y se acrecentó más tarde para la explotación del café. A través de los ejidos y de la pequeña propiedad se impuso un sistema parcelario minifundista, con una producción diversificada de cultivos de autoconsumo y cafetales en las áreas templadas de la sierra.

Durante este proceso, las mejores tierras permanecieron en manos de rancheros mestizos. Early considera que la economia de las localidades de la zona templada -según su investigación de campo realizada a mediados de los años setenta- se basaba de un 50 a un 75 por ciento en la economia del café. En la zona fria predominaba, mientras tanto, una economia basada en agricultura de subsistencia, trabajo asalariado y una incipiente explotación de los recursos del bosque.

En los pueblos de la parte alta de la sierra se localizan aún hoy en día, los 
terrenos menos fértiles; sus habitantes continúan proveyendo de mano de obra a las fincas cafetaleras y cañeras de las estribaciones de la serrania y de las planicies cálidas del centro del estado de Veracruz. La población de la zona templada de la sierra, correspondiente en su mayor parte al municipio de Zongolica, ha combinado los cultivos de subsistencia con el café, producto comercial que no obstante los altibajos en los precios del mercado, ha generado una economia en cierta medida más dinámica y menos dependiente del trabajo asalariado que lo que ocurre en la parte alta de la sierra.

\section{f) Los pueblos nahuas de hoy.}

A partir de la segunda mitad del siglo XVIII, cuando los empresarios del tabaco y de las haciendas azucareras del valle del Orizaba reclutaron mano de obra entre la población indigena, se estableció la dinámica de relaciones entre los habitantes de las partes altas y las plantaciones de las tierras templadas y cálidas de la zona de transición, asi como de las planicies del centro de la entidad veracruzana. Los indigenas de la tierra fria han aportado desde entonces su fuerza de trabajo en los cultivos comerciales de las llanuras y vertientes costeras de la Sierra Madre Oriental.

Desde mediados de los años ochenta, habitantes de los municipios de la zona fria, carpinteros, carboneros y vendedores de éstos y otros productos forestales, incursionan en las ciudades del centro del estado de Veracruz y del sureste del pais, en la búsqueda de ingresos alternos a los proporcionados por las actividades agricolas. Hay quienes se establecen en los centros urbanos de forma definitiva dentro del sector informal.

Estos campos de actividad en los cuales los nahuas se desempeñan fuera de sus lugares de origen, han sido los vehículos de referencia para su identificación dentro de un sistema de relaciones asimétrico. De este modo se ha conformado el nivel de identificación más general: el ser macehual. Ser macehual implica dos condiciones, la de hablante de náhuatl y la de campesino pobre. Cuando una persona originaria de un pueblo de la sierra, hablante de náhuatl y de familia campesina adopta ciertos patrones de aculturación, se considera que pierde su calidad de macehual (Hasler, 1996:19-22).

En los pueblos de la parte alta de la sierra se considera que los cafetales proporcionan condiciones menos seguras que las plantaciones de caña. Los cafetales más próximos se ubican en la franja de la sierra ubicada hacia el sureste, tierra húmeda y cálida, zona de transición entre la montaña y las planicies cañeras de Córdoba y Tezonapa y de las costas del Golfo de México. Es un ámbito preñado de profundas cañadas, nacimientos de agua, pobre en infraestructura caminera y húmedo en exceso. El trabajo en las plantaciones, si bien implica un cierto nivel de contraste con la población de habla castellana, 
permite la reagrupación entre miembros del mismo grupo y la implementación de nexos normativos y marcos simbólicos de referencia, que casi siempre implican una vuelta al lugar de origen y una defensa reciproca en el seno de un entorno hostil.

El oficio de venta ambulante en la ciudad, especialmente de productos de carpinteria requiere de una movilización con rumbo incierto y durante un periodo indeterminado de tiempo, a ciudades localizadas en un rango geográfico que puede abarcar desde el centro hasta el sureste del pais. Durante estos viajes, carpinteros de Atlehuaya, Tepexititla, Quechulingo y Zacamilola congregaciones de Atlahuilco- recorren las calles de las ciudades con su producción de uno o dos meses de trabajo -generalmente sillas y mesas- hasta agotar la mercancia. Mientras tanto, el grupo familiar espera su regreso, sin saber cuánto tiempo pueden tardar ni el lugar en que se encuentran. Sólo se tiene la certeza de que volverán con suficiente dinero para solventar los gastos más apremiantes, producir de nuevo mercancia y volver a partir. Generalmente los jóvenes vendedores que se aventuran en estos viajes, lo hacen en compañía de uno, dos o más compañeros, familiares o vecinos que también trasladan sus productos. De este modo, se comparten gastos, experiencias y ayuda mutua.

El espacio regional constituye una unidad territorial significante en las interacciones entre las localidades y el entorno extraregional, representando una forma de intermediación que trasciende las divisiones intrarregionales. El manejo de este marco común de referencia constituye una instancia de identificación que se manifiesta en el uso de una misma lengua, un territorio compartido y una serie de elementos que configuran lo que podria llamarse una región cultural. Se conocen con precisión las rutas de acceso a cada pueblo, las devociones locales, los hábitos y productos especificos de cada uno de ellos, los modismos idiomáticos, los detalles de la indumentaria. La utilización física del entorno implica un manejo del espacio que responde a una serie de subdivisiones, cuya expresión minima es el paraje o grupo residencial.

Los nahuas tienen una visión del espacio regional signada por mitos de origen y lugares sagrados que posibilitan su aprehensión simbólica. Por lo menos desde la colonia, existieron rutas de arriería y de mercadeo que comunicaron a los pueblos de la sierra de Zongolica entre si. De este modo, así como existe un conocimiento del ámbito regional a partir de las rutas de arrieria, del comercio intinerante de los productos artesanales, de la milpa o del bosque, la mitologia regional y las devociones locales denotan los ámbitos significativos en el seno de la región en su conjunto. De ahí que, tal y como en cada pueblo o municipio existe un complejo ceremonial encaminado a sostener un ciclo ritual anual, cuyo eje es el santo tutelar, en el nivel regional se reproduce este esquema a través de la celebración de los santos patronos de cada pueblo. Es decir, se expresa una simetria en la relación entre: 
- cada mayordomo/ un santo (correspondiente al ciclo ceremonial de un pueblo o muncipio), y

- cada pueblo/un santo patrono (correspondiente al ciclo ceremonial de la región).

De la misma forma en que los habitantes de cada municipio descargan la celebración de las fiestas menos importantes en el mayordomo responsable y su comitiva, y son las fiestas de renovación del centro ceremonial los espacios vigentes de cohesión y de conjunto, en el contexto regional se considera que son las fiestas de San Pedro Tequila y de San Francisco Zongolica, las que se ubican en lo alto de la jerarquia; celebraciones que convocan a un gran número de participantes procedentes de distintos puntos de la sierra. En ambos niveles el ciclo es responsabilidad del conjunto: en el pueblo, los habitantes se reparten el compromiso de festejar a cada uno de los santos del ciclo ceremonial, mientras que en el nivel regional, cada pueblo festeja a su santo tutelar beneficiándose de ello los habitantes de todo el territorio.

Los pueblos de Zongolica y Tequila son puntos geográficos de confluencia para la realización de intercambios simbólicos y materiales entre los habitantes de la serrania. Sistemas de mercadeo, redes de parentesco ritual, apropiación fisica del territorio y devoción a los santos tutelares, se convierten en los vehiculos culturales y sociales que sustentan esta oposición socioterritorial al interior de la región nahua.

Las celebraciones festivas de la región entera refieren un ciclo mitológico que presupone la formación de cada pueblo, ciclo que se refiere a hazañas míticas que justifican la adscripción hacia la tutela de determinado santo patrono. Esta geografía mítica pone de relieve tanto los contrastes ecológicos y las transformaciones del entorno, como una imagen del cosmos regida por una sucesión de fiestas en honor de las divinidades. Permite a los pobladores manifestar su adscripción hacia una de las dos partes del territorio a través de las actividades ceremoniales, bajo una estructura piramidal en cuya base se encuentran los rituales domésticos (Galinier, 1990: 42-43). En el centro de esta estructura se ubican aquellas fiestas dedicadas al sostenimiento del ciclo ritual comunitario y en la cúspide, la parroquia o santuario regional con San Francisco o San Pedro a la cabeza.

Por lo tanto, la mayoria de los habitantes de la sierra, además de participar en el sostenimiento del ciclo ritual de su pueblo o municipio, participa en este complejo ceremonial amplio, en cuya cima se localiza el culto a las dos figuras principales del ciclo ceremonial regional: San Francisco, Santo Patrono de Zongolica y San Pedro, Santo Patrono de Tequila. De modo que, así como en el ciclo ritual de Atlahuilco, el pueblo entero se responsabiliza del sostenimiento del culto a las imágenes de su calendario, mediante la distribución entre sus 
habitantes del financiamiento y organización de cada una de las fiestas, los nahuas de la sierra de Zongolica se benefician en conjunto de las festividades que cada pueblo organiza para su santo patrono, organizándose para ello en dos grandes subdivisiones.

En casi todos los pueblos de la sierra de Zongolica, el santo patrono habitó antes en el punto más alto del municipio; en Atlahuilco este punto fue Atlehuaya, congregación enclavada en los limites con el municipio de Soledad Atzompa. En Zongolica, se supone que el pueblo estuvo ubicado antes en una de las pronunciadas elevaciones que circundan el valle donde hoy se encajona, el cerro de Tecuapa. (Aguirre Beltrán, 1986: 83). Según Galinier (op. cit.: 112), es muy antigua entre los pueblos mesoamericanos, la idea de que todo espacio habitado mantiene correspondencias simbólicas con un punto ceremonial situado en un punto elevado.

Entre los nahuas, estas concepciones hacen referencia a una metáfora cósmica de la oposición arriba/abajo: Tlaltikpatl, la superficie terrestre, madre nutricia de los agricultores, y Tlalokan, el señor de la tierra, protector de los animales y de la vegetación silvestre. Acordes con este esquema, los pueblos de la zona fría ubican su lugar en la superficie, la parte alta y benéfica del universo, desde la cual clasifican el entorno como en una especie de circulos concéntricos. En esta clasificación, las cañadas húmedas y profundas de la tierra caliente constituyen un espacio temido, digno de todas las reservas y receptáculo de ofrendas en los días de la Santa Cruz, ceremonia de petición de lluvias y de bendición de los nacimientos de agua. 
POBLACION DE LA SIERRA DE ZONGOLICA.

$\begin{array}{lcc}\text { MUNICIPIO } & \text { POBLACION TOTAL } & \text { HABLANTES DE NAHUATL } \\ & 5240 & 4247 \\ \text { ASTACINGA } & 7292 & 6055 \\ \text { ATLAHUILCO } & 1893 & 5477 \\ \text { MAGDALENA } & 7201 & 1538 \\ \text { MIXTLA } & 12682 & 6071 \\ \text { RAFAEL DELGADO } & 3609 & 2994 \\ \text { LOS REYES } & 1777 & 1446 \\ \text { TENEJAPA } & 14801 & 12384 \\ \text { SOLEDAD ATZOMPA } & 15844 & 12876 \\ \text { TEHUIPANGO } & 10676 & 8414 \\ \text { TEQUILA } & 4077 & 2746 \\ \text { TEXHUACAN } & 5444 & 4537 \\ \text { TLAQUILPA } & 4212 & 797 \\ \text { XOXOCOTLA } & 35615 & 24559 \\ \text { ZONGOLICA } & & 94141 \quad(72.21 \%) \\ \text { TOTAL } & 130363 & \end{array}$

Fuente: INEGI, Conteo de Población. 1995. Estado de Veracruz.

\section{g) La conformación del espacio municipal de Atlahuico.}

El municipio de Atlahuilco se compone de un territorio de aproximadamente 60 kilómetros cuadrados, extensión adquirida mediante compra a quien fuera la última propietaria de la hacienda de cabras, la heredera del teniente coronel Aniceto José de Benavides. Actualmente el municipio se integra por las localidades de Atlahuilco, Zacamilola, -hasta ahora el de mayor número de habitantes- Quechulingo, Atlehuaya, Tepexititla, Tambola, Atetecoxko, y una serie de pequeñas agrupaciones residenciales asentadas en parajes dispersos por el reducido pero abrupto territorio.

Como ha sido costumbre desde que se adquirió la extensión que conforma el municipio, el presidente municipal en turno guarda celosamente las escrituras originales que legitiman la propiedad del territorio. Los amarillentos papeles, con la paleografia de mediados del siglo pasado, establecen con detalle los puntos en los que se colocaron las mojoneras para señalar las colindancias con 
los terrenos de Tlaquilpa, Soledad Atzompa, Los Reyes y Tequila. En dicho documento, con fecha de 1847, se estipula que Matilde Benavides, hija de Aniceto José de Benavides, vende a los pueblos de Tequila, Atlahuilco y Atlanca, los terrenos que aún conserva en sus manos por un precio de $\$ 6700$, los cuales se cubren de la siguiente manera: a Tequila le corresponde liquidar $\$ 5400$, a Atlahuilco $\$ 1000$ y a Atlanca $\$ 300$.

En la Historia Tolteca-Chichimeca se menciona un lugar llamado Atlahuimolco, paso de la peregrinación nonoualca-chichimeca en su tránsito hacia la serrania de Zongolica. En este lugar, Xelhuan, tlatoani de los nonoualca haizo penitencia y venció a los residentes de aquel lugar, enemistándose con ellos por la posesión del artefacto adivinatorio llamado atlahuimolli (Aguirre Beltrán, 1986: 65). La tradición oral asigna el origen del nombre de la localidad al hecho de que se encontraba ahi un nacimiento de agua, el cual emanaba de una cueva oscura. Para obtener el líquido de dicha oquedad era necesario alumbrarse, lo cual explica según los lugareños, la formación del topónimo, conformado por las partículas atl, agua y tlahuilli, luz. Aguirre Beltrán señala la posibilidad de que este topónimo haga referencia al proceso adivinatorio que consiste en descifrar las imágenes que se reflejan en el agua a la luz de una vela o candela, aún en uso en distintos puntos del área mesoamericana (ibid.).

Hacia fines del siglo XVI, Quechulinco (hoy Quechulingo) y Zacamillullan (hoy Zacamilola), fungen como pueblos sujetos de la República de Naturales con cabecera en Tequila. No se tienen noticias de que el pueblo de Atlahuilco, bajo ese nombre o alguno similar, existiera como estancia o pueblo sujeto de la República de Tequila. Los testimonios y la información disponible hacen suponer que el asentamiento actual, cabecera del municipio, fue fundado en el periodo inmediatamente posterior al establecimiento de la República Mexicana. Para entonces se encontraba ya construido el templo de Atlahuilco, considerado "capilla", puesto que fue asignado a la jurisdicción de la parroquia con cabecera en Tequila. Durante los primeros años de la Colonia, de 1530 a 1561, la evangelización en la sierra de Zongolica estuvo a cargo de la orden de los franciscanos. Los frailes fueron tempranamente reemplazados por el clero secular perteneciente al obispado de Tlaxcala, y durante todo el siglo XVI, el cura asignado a esta zona residia en Tequila y en Zongolica, desde donde ejercia su labor (Aguirre Beltrán, op. cit.: 24). Correspondia a este párroco suministrar los servicios religiosos a las apartadas poblaciones de Zacamilola, Quechulingo, Atlehuaya y Tepexititla.

Aparentemente el templo de Atlahuilco (en cuya campana de bronce se encuentra grabada la fecha de 1892), fue construido una vez que desaparecieron las Repüblicas de Naturales. Se eligió para su construcción el valle donde se ubican también las oficinas del ayuntamiento, el cementerio y la Capilla del Calvario. Antes de este momento, no existian viviendas en el angosto valle que 
hoy da forma al poblado de Atlahuilco; las familias indigenas se encontraban dispersas en parajes y agrupaciones residenciales ubicadas en los lomerios, cañadas y elevaciones, en alturas de 1800 a 2000 metros sobre el nivel del mar. Al establecerse el municipio libre con cabecera municipal en el valle de Atlahuilco, las autoridades indigenas del nuevo ayuntamiento se vieron obligadas a residir durante el tiempo de su gestión en el nuevo asentamiento.

Todo hace suponer que antes de este evento, el poblado principal era Zacamilola, localidad que hasta hoy concentra un mayor número de habitantes que la propia cabecera municipal; este asentamiento aparece registrado en la Memoria de Doctrinas de clérigos (cit. en Aguirre Beltrán, 1986: 92), documento que aporta información acerca de los partidos que hacia el siglo XVI conformaban el Obispado de Tlaxcala, y al cual pertenecieron en aquellos años las provincias de San Francisco Zongolica y San Pedro Tequila. En dicho documento se establece que la cabecera de San Pedro Tequila tiene ocho estancias, entre éstas, Los Reyes de Zacamillullan y San Francisco Quechulingo, y que ambas distan dos leguas de la cabecera.

Hoy en dia, el templo de Atlahuilco continúa adscrito a la parroquia de Tequila, y como en tiempos de la colonia, es ahi donde reside el párroco que atiende a una serie de localidades, entre otras, las pertenecientes a este municipio. Existen cuatro parroquias más en la sierra de Zongolica, cuyas cabeceras se ubican en los pueblos de Zongolica, Texhuacan, Tlaquilpa y Tehuipango.

El templo de Tequila, dedicado al apóstol San Pedro, se construyó sobre una elevación desde la cual se aprecian los lomerios, depresiones y pendientes en los que se asientan las viviendas de los barrios y parajes del pueblo. El resto de edificaciones que se ubican en el centro del poblado, una plazuela rodeada de comercios y las viviendas de las familias acomodadas, constituye el único espacio plano y con un patrón de asentamiento urbano. El establecimiento en este lugar de población criolla y mestiza durante el periodo revolucionario, a principios de siglo, habria de influir en su progresiva conformación como un punto importante de mercadeo, de acaparamiento de productos agrícolas y forestales, y de control politico y económico sobre las poblaciones ubicadas en la ruta Tequila-Tehuipango.

Georgette Sousstelle, en su trabajo publicado en 1958, señalaba que en Tequila resultaba -como hoy- fácilmente distinguible "el centro" del resto del pueblo, conocido como Teopantitlan, tal y como en Atlahuilco se denomina al espacio donde se encuentra el templo, los comercios, las escuelas y las oficinas del ayuntamiento. La investigadora francesa señaló que en aquel momento, el centro de Tequila constituía un punto importante para una serie de poblados contiguos, incluido Atlahuilco, en los cuales no se presentaba gran movimiento a menos que se lleve a cabo una celebración religiosa. (Sousstelle, 1958: 5-7). 
El poblado de Zacamilola, hoy congregación del municipio de Atlahuilco fue, como mencionaba lineas arriba, un asentamiento precolonial; al igual que el resto de las localidades de Atlahuilco la totalidad de sus habitantes es nahuahablante. Zacamilola se ubicó, desde tiempo atrás, en un lugar estratégico: en el cruce de caminos de herradura que atravesaban la sierra, en dirección a los distintos puntos cardinales. Es decir, en la ruta que comunica a los poblados serranos de sur a norte, desde Tehuipango y atravesando por San Juan Texhuacan, Tequila y Tenejapa hasta llegar a la ciudad de Orizaba; por otra parte, era también un punto estratégico para acceder de manera relativamente directa hacia el municipio de Soledad Atzompa, la otra ruta de salida hacia el valle de Orizaba, pasando por Ciudad Mendoza, asi como para comunicar al pueblo de Los Reyes con el de San Juan Texhuacan y el de Tlaquilpa.

Atlahuilco como pueblo, se funda pues hacia mediados del siglo pasado. Una vez configurado como ayuntamiento se conforma como centro político, administrativo y religioso del territorio municipal. Es en esa época cuando arriba a la naciente localidad un hombre mestizo procedente de Tlaquilpa, llamado Guadalupe Montalvo y casado con Apolonia Arellano, también de Tlaquilpa. Fundan en el valle casi despoblado entonces, una pastoria de ganado caprino, asi como una tienda y posta del camino para quienes transitaban por la ruta Tequipango-Tequila. Don Guadalupe trajo consigo peones, pastores, arrieros y cocineras indigenas de Tlaquilpa.

Con el paso de los años procreó en Atlahuilco cinco hijos, al mismo tiempo que se apropió paulatinamente de parte de los terrenos más fértiles del valle, que por entonces nadie cultivaba. Construyó una amplia casa de madera a un costado del templo, en el punto central del nuevo municipio pero donde aún no habia una sola vivienda. Aunque ésta fue una construcción modesta, -según testimonios de sus descendientes- contrastaba notablemente con la típica vivienda indigena de aquella época: agrupaciones residenciales dispuestas de forma dispersa, levantadas con los troncos y varas arrancados al bosque y techos de zacate silvestre.

Proliferaron en ese tiempo -en el valle- los rebaños de cabras, la cría de cerdos, de aves de corral y perros de caza pertenecientes a los inmigrantes. Para entonces, existia ya una red de relaciones entre los pobladores mestizos establecidos en algunas de las nuevas cabeceras municipales, y en las antiguas cabeceras de las Repúblicas de Indios, Zongolica y Tequila. Se dice que las familias de mestizos llegaron durante la época de las luchas de la Revolución Mexicana hacia principios de siglo, cuando pobladores del piedemonte poblano y del valle de Tehuacan, huyendo de las huestes revolucionarias, se establecieron en algunos de los entonces remotos poblados serranos. Se trató, sin embargo, de una moderada inmigración que no afectó por igual a todos los pueblos de la sierra; mientras que en Astacinga, Mixtla, Tehuipango y Soledad Atzompa, no 
existió prácticamente inmigración mestiza alguna, en Texhuacan se aprecia la influencia cultural y demográfica de un contingente de poblanos procedentes de la Sierra Negra y del Valle de Tehuacán, mientras que en Atlahuilco y Tlaquilpa, sólo una $o$ dos familias inmigrantes influyeron en su conformación sociodemográfica.

En el municipio de Zongolica, ubicado en la zona de transición entre la tierra fria y la tierra caliente, se manifestó un proceso distinto. Como se señalaba páginas atrás, el auge del tabaco y posteriormente del café en esta zona, propició la incursion de rancheros mestizos que fundaron pequeñas localidades enclavadas en las barrancas de Atzinco y Coyametla. Se perfiló un tipo de producción comercial en determinados puntos del municipio, influido por la afluencia de mestizos, aún cuando en términos numéricos predominara la población de habla nahua. Estas particularidades de las localidades zongoliqueñas, le sugirieron a Daniel K. Early su caracterización como "comunidades abiertas", aplicando la terminologia de Wolf (Early, 1982: 29-32).

Pobladores de Atlahuilco narran que Don Guadalupe Montalvo y otros hombres mestizos de la zona, se reunian para salir a los montes y realizar la caceria de los animales silvestres que aún se encontraban con facilidad: venados, coyotes y otras especies menores que casi han desaparecido hoy en dia. Estas relaciones permitian a los advenedizos mestizos afianzar paulatinamente su control sobre los recursos estratégicos de la sierra, implementar el pequeño comercio y la intermediación de los productos locales, y desarrollar estrategias para controlar económica y políticamente a la población indigena.

Si bien durante la primera generación de los descendientes de don Guadalupe, los hijos en edad casadera escogieron su cónyuge de entre las familias mestizas establecidas en Atlahuilco y los pueblos vecinos, al paso de dos generaciones ello ya no fue posible y se volvieron frecuentes las uniones con hombres y mujeres nahuas. Los inmigrados no indios adoptaron gran parte de los patrones culturales locales, aprendieron la lengua, los hábitos y conocimientos del entorno, aunque siempre ubicados en la parte central del pueblo y en las esferas locales de poder.

El pueblo de Zongolica se habia ya constituido, como herencia de la colonia, como el enclave mestizo más importante en la sierra, y a partir de la introducción del café habia logrado aprovechar en su beneficio, las condiciones poco favorables para que los campesinos nahuas de las tierras templadas procesaran y comercializaran por sí mismos este producto. En el resto de los pueblos de la zona fria, las familias de inmigrantes mestizos se establecieron como comerciantes e intermediarios de los productos que los indigenas traian de las rancherias. Intercambiaban animales de corral y productos de la milpa y del bosque a cambio de objetos y enseres de primera necesidad, de fabricación industrial o de importación regional (velas, azúcar, sal, jabón, petróleo, etc.). 
En Atlahuilco la familia Montalvo estableció, además de los rebaños y cría de animales de granja, una de las primeras tiendas y horno de pan ubicados en la zona fria. Asi mismo, los corredores de la casa de madera se convirtieron en posada para los caminantes, arrieros y pastores que atravesaban la sierra, desembocando en el plan que les anunciaba la proximidad del pueblo de Tequila y en consecuencia, del valle de Orizaba. De ahi que durante algún tiempo, -como hasta la fecha en cierta medida- Atlahuilco se convirtió en un punto donde se "atajaba" a los indigenas procedentes de las localidades y parajes de Zacamilola, Tepexititla, Atetecoxko, Atlehuaya, Tambola y Quechulingo, quienes a menudo dejaban ahi sus mercancias (madera, flores, leña, hongos, quelites y fruta) antes de llegar al tianguis dominical de Tequila.

Don Guadalupe Montalvo aprovechó también su llegada como secretario municipal -en aquel tiempo reservado a hombres mestizos que dominaran la lengua castellana y su escritura- para insertarse en la naciente estructura del poder político local. Percibió la importancia de instalarse en un punto obligado de paso hacia Tequila, ya fuera transitando desde un pueblo tan remoto como Tehuipango, o de los parajes y rancherias circundantes. Su emigración de Tlaquilpa le evitó la confrontación directa y la competencia con otra familia criolla que fincaba ahí una prosperidad notable y creciente.

Don Guadalupe Montalvo fundaria pues el pueblo de Atlahuilco como un espacio residencial. Antes de su llegada, las viviendas indigenas se encontraban dispersas, organizadas en parajes y ubicadas en lomerios y rancherias, más cerca o más lejos del valle donde se estableció la cabecera municipal. Dos generaciones después, Atlahuilco se convertia en el asentamiento de varias familias mestizas con su descendencia: don Guadalupe y doña Apolonia procrearon un hijo varón, Severo, y cuatro hijas, Leonor, Amelia, Amada y Teodora, las cuales contrajeron matrimonio con hombres mestizos de fuera de la localidad y emigraron de Atlahuilco. Severo casó con una mujer de Zongolica, también mestiza, de nombre Bernarda Sáenz, quien vino a vivir al pueblo de su marido.

Sin embargo, ya los descendientes de esta pareja, se insertaron en las redes locales y en la cultura indigena contrayendo matrimonio con hombres y mujeres nahuas. Fueron dos hombres y dos mujeres que se unieron a personas de origen local, de lengua y cultura indigena, con quienes se establecieron en los alrededores de la casa paterna, en el centro del pueblo. Las mujeres siguieron el modelo de residencia virilocal y se trasladaron al paraje o pueblo de su marido. Una de ellas, doña Reina Montalvo, se estableció en Atetecoxko al casarse con un hombre de dicha localidad (hoy Departamento del municipio de Atlahuilco). Vivió durante varios años en el seno de aquella familia nahua; aprendió el idioma con fluidez, la tecnología doméstica y agricola, y al cabo de poco tiempo, habia acumulado un bagaje importante de conocimientos de etnobotánica y 
prácticas curativas que la llevarian a convertirse en una reconocida curandera y partera, experta en el manejo de ambos códigos culturales.

Uno de los hijos varones de don Guadalupe y doña Apolonia, el menor, se quedó a vivir en la casa de sus padres, donde aún reside su viuda -una mujer nahuacon algunos de sus hijos y nietos. El resto fundaron sus hogares en el mismo espacio central del pueblo, donde también se ubicó la primera escuela primaria del municipio y la sede del ayuntamiento, que sería conocida por la población indigena como "la opicina", aunque desde entonces ya funcionaba el referente religioso como el marcador de dicho espacio: Teopantitla, término con el que hasta hoy los habitantes de Atlahuilco denominan a la cabecera municipal.

Los nexos parentales de la familia Montalvo, Sáenz y Arellano atraerian a algunos personajes más, también de origen mestizo, que se establecieron en el pueblo mezclándose con la población local, pero consolidando con su ubicación y la de su descendencia en el valle, el pueblo-cabecera como un conglomerado cada vez más visible. Establecerian ahí pequeños negocios como panaderias o tendajones, al tiempo que se involucraban en las labores agricolas y las actividades ligadas a la utilización del bosque como la elaboración e intermediación de carbón y tablas. El dominio del idioma castellano y la posición de intermediación cultural fueron factores que propiciaron su consolidación temporal como clase politica.

Durante algunas décadas, hacia mediados del siglo veinte, los hombres pertenecientes a esta élite mestiza se sucedieron en las puestos públicos sin descuidar sus nexos parentales y de compadrazgo con la población indigena, y aprovechando su ubicación sociocultural para encaminarse al mismo tiempo en la carrera magisterial. Los pobladores nahuas, habituados a establecerse cerca de los campos de cultivo, permanecian mientras tanto en los parajes y elevaciones circundantes, algunas más cerca del valle, otras allende dos o más horas de camino por la montaña.

De este modo, con el correr del siglo, la localidad fue creciendo a lo largo del camino, hasta quedar casi poblada de viviendas con campos contiguos y hacer casi desaparecer la separación entre Atlahuilco-cabecera y parajes como Atlahuilapa o Tlalxitla. Durante algún tiempo se generó cierta rivalidad entre distintas facciones, especialmente de las familias del centro con los habitantes de Atlahuilapa, barrio o paraje de la cabecera y asiento de un pequeño grupo de familias que también competia por espacios en el ámbito politico y económico local.

Es preciso señalar, sin embargo, que este sector de población se incorporaba a un entorno social, que desde tiempo atrás habia desarrollado sus propias formas de organización y de control del territorio y sus recursos. Las alianzas matrimoniales, las relaciones de parentesco ritual y la participación en el 
sistema de cargos religiosos fueron formas de insertarse en las redes locales y de afianzar su posición en el seno de una sociedad netamente indígena. La tradición oral asigna a doña Apolonia Arellano el haber sido la primera en organizar una mayordomia para San Martin, el santo patrono de Atlahuilco, cuya imagen fue traida de Amatlán de los Reyes, estado de Puebla. Según esta versión, la familia Montalvo Arellano habria sido la fundadora de la mayordomia de San Martin, y durante los primeros años de devoción a esta imagen fueron miembros de la parentela quienes se hicieron cargo de celebrar su fiesta.

Al interior del pueblo-cabecera que se formaba y crecia conforme el siglo avanzaba, se fue perfilando un tipo de distribución del poder que se fincaba en las alianzas con las familias poderosas de los distintos puntos de la ruta TequilaTlaquilpa y que se conectaba con el polo de poder politico más importante a nivel regional, los capitales cafetaleros que crecian en el pueblo de Zongolica y dominaban la producción y el comercio de la zona templada y parte de la zona fría. Una de las descendientes de la familia Montalvo me narró la violencia que hacia mediados de este siglo se desató en Atlahuilco, como consecuencia de las rivalidades entre distintas facciones, integradas básicamente por familias de mestizos que competian por ganar espacios de poder y de control politico. Estas pugnas, generaron fuertes enfrentamientos, una generación después de la llegada de los Arellano, que en ocasiones culminaron en asesinatos.

La inserción en la esfera de poder local por parte de los mestizos implicaria también una participación activa y destacada en el ámbito ceremonial, el cual se encontraba hasta entonces estrechamente imbricado con el ejercicio politico. Si bien no se trataba de un sistema de cargos alternante (entre un puesto civil y uno religioso), la participación en el campo de las relaciones de parentesco ritual y el sistema de mayordomias, proporcionaba un estatus útil para acceder a un puesto político.

Esta situación pudo sostenerse durante varias décadas, en tanto los pobladores del resto de localidades del municipio aún se mantenian fisicamente aislados, en condiciones de supervivencia altamente dificiles. Esta condición de aislamiento y marginalidad de la mayoria de los habitantes de Atlahuilco, facilitó la emergencia y consolidación de este grupo de mestizos bilingües como los principales actores de la vida politico-administrativa del municipio.

Según testimonios de habitantes Atlahuilco, antes de estos acontecimientos funcionaba un Consejo de Ancianos, el cual designaba tanto a las autoridades civiles como a las religiosas. Se manifestaba una clara herencia del gobierno colonial en la que perduraban aún funcionarios menores de la administración prehispánica como los topiles y tequitlahtos que aún hoy en día ejercen funciones en Atlahuilco y otros pueblos de la sierra de Zongolica. Tanto los funcionarios de puestos del cabildo, como los patrocinadores de las fiestas religiosas, asumian su cargo como una forma de servicio obligatorio hacia su 
pueblo. Los "principales" o Consejo de Ancianos tenian la atribución de sancionar a los elegidos que se resistieran a asumir su responsabilidad, recluyéndolos en la cárcel hasta que se aceptara "el compromiso".

De este modo, el control politico y económico local de Atlahuilco antes en manos de los propios indigenas -especialmente de Zacamilola, el asentamiento mayoritario- se vio debilitado con la presencia de los inmigrantes mestizos y su descendencia, quienes se apropiaron del mismo por lo menos durante dos generaciones. Sin embargo, llegaria el momento en que la familia Montalvo Arellano veria su decadencia económica. A la muerte de los abuelos fundadores, sus descendientes, inmersos en las rencillas y disputas locales y bajo las condiciones resultantes de la Revolución Mexicana que afectaron a los hacendados y grandes propietarios, perdieron parte de sus prebendas y propiedades.

Distintas localidades del municipio solicitaron dotaciones ejidales, pero dado que la mayor parte de los terrenos estaban siendo usufructuados como pequeñas propiedades, solamente se asignaron 70 hectáreas de dotación, mismas que se otorgaron a la congregación de Zacamilola y se utilizaron durante algún tiempo como ejido colectivo. Más tarde, los ejidatarios consideraron conveniente el usufructo de este terreno de manera individual y decidieron fraccionar el terreno entre los derechosos; la utilización de los recursos forestales de dicha extensión habia llegado a convertirse en fuente de conflictos.

Aún después del fin de su auge económico, el núcleo de población mestiza de Atlahuilco, con estrechos y crecientes vinculos de parentesco y compadrazgo con indigenas de distintas localidades del municipio, habria de seguir teniendo un papel importante en la politica local. Los descendientes de la familia Montalvo Arellano se habian consolidado como el sector más instruido en el pueblo, en términos de sus posibilidades de intermediación cultural. Habian realizado uniones matrimoniales con hombres $\mathrm{y}$ mujeres indigenas y procreado hijos bilingües, configurando asi paulatinamente, tal vez sin proponérselo, lo que llegaria a ser en las dos últimas generaciones el grupo de "los maestros". Siendo competentes en la escritura y profesores en las escuelas regionales o locales, se encontraron posibilitados para sacar provecho de ciertos niveles de participación política partidista y del pequeño comercio.

Mientras tanto, al tiempo que gran parte de la población indigena del territorio municipal se mantenia en las elevaciones de los alrededores, aún boscosas y poco accesibles, el centro del pueblo veía llegar paulatinamente a familias indigenas que no encontraban espacios disponibles en los parajes, o bien que buscaban acceder a las ventajas que proporcionaba la cercania del camino, de las escuelas y de los mercados. 


\section{h) La dinámica espacial del municipio .}

Como señala Medina (1996: 7) la homologación de la categoria de comunidad con la de municipio, como lo propusiera Sol Tax (1937) en su trabajo acerca de los sistemas de cargos en Guatemala, no resulta viable en una gran cantidad de contextos indígenas de México. Sin embargo, me propongo señalar que la dinámica espacial de Atlahuilco responde en términos generales al municipio como referente fundamental de la identidad comunitaria. La dimensión espacial o unidad de análisis ha sido tema substancial en los estudios sobre sistemas de cargos, sin embargo, esta perspectiva no siempre ha considerado la complejidad de las situaciones en que se reproduce la comunidad indigena.

Esta temática se refiere pues a aspectos insuficientemente tratados en los estudios sobre la organización social de los pueblos indigenas contemporáneos: las unidades de intermediación social entre los hogares y las unidades sociales más amplias. Me interesa acercarme a esta dinámica en el escenario de la zona fria de la sierra de Zongolica, como una serie de estructuras formales ligadas en un continuum de escenarios de acción social. (Sandstrom, 1996).

En este apartado, me propongo presentar una aproximación a las relaciones que operan entre las distintas instancias territoriales del municipio de Atlahuilco, las cuales se asumen como locales desde el punto de vista émico, es decir, como pertenecientes a una unidad de territorio, un pueblo, concepto que refiere para los nahuas la adscripción a dos puntos de referencia comunes a todos sus pobladores: el municipio y el santo patrono. Estas relaciones proveen de bases para un tipo particular de unidad entre sus miembros, una identidad (Adams, 1995: 52). Se trata de instancias socioespaciales que operan como diferentes segmentos y al mismo tiempo mantienen una dimensión local que los unifica, representando una forma de intermediación entre los grupos domésticos y las estructuras regionales y nacionales (Sandstrom, 1996).

Uno de los aspectos relevantes de estas unidades es que integran un nivel de organización social con otro (Mulhare, 1996: 93), lo cual constituye un elemento en la definición de la identidad local y en la vida politica y ceremonial. Por otra parte, cada subdivisión, constituye una unidad socialmente incompleta, distintiva caracteristica según Cancian, de esta forma social, puesto que parte considerable de la vida pública de sus miembros trasciende las fronteras de las mismas, por ejemplo en relación a los matrimonios y al desempeño en los cargos civiles y los religiosos (Cancian, 1996: 215). Este tipo de agrupaciones han sido conceptualizadas en los estudios etnográficos como parajes, barrios, snaés, grupos de ojo de agua, linajes, grupos de descendencia, segmentos, subcomunidades o subdivisiones; mientras que las instancias oficiales las 
estrategias en beneficio de los habitantes de cada instancia socioespacial, y en ocasiones se transforman, proporcionando la apariencia de una pérdida de coherencia interna y de difuminación de fronteras claras (Sandstrom, op. cit.: 161-162).

De acuerdo con Mulhare (op. cit.), este tipo de segmentos sociales son simultáneamente una alianza institucionalizada de hogares o grupos domésticos y una subdivisión formal en la comunidad, en el seno de un orden jerárquico verticalmente integrado. Pero aún cuando hoy en dia existe una diversidad de criterios para la delimitación de estos segmentos, a través de distintas vias se asegura que los grupos domésticos del conjunto social se encuentren incorporados en un mismo sistema.

Como Mulhare apunta, la lógica de este sistema de subdivisiones trasciende las categorias convencionales de parentesco, de territorialidad y de política. De hecho la membresia a uno de estos segmentos no se adquiere a partir de un solo criterio, como podria ser el de parentesco. Antes bien, se combinan distintos principios de organización, en diferentes proporciones, que dependen de las prácticas locales: parentesco, tenencia de la tierra, lugar de nacimiento, intereses comunes, etc. La rotación de tareas y cargos civiles y religiosos, los sistemas de ayuda mutua y la unión e identificación de sus miembros frente al resto de la comunidad, propician una autonomia que trasciende en la competencia en favor de la propia subdivisión (op. cit.: 94-98).

Es conveniente destacar la importancia de esta instancia socioespacial que Cancian (1996: 216) llama "de mediación", puesto que representa una unidad ' intermedia en las relaciones entre los hogares, la comunidad y el espacio regional: las relaciones con el mundo exterior son canalizadas a través de los residentes que tienen cierto poder y estatus adentro del caserio. Hoy en día resulta de interés partir de los modelos y descripciones desarrolladas en torno a este punto, para comprender de qué manera evolucionan estos parajes y las causas y efectos de esta evolución. El asunto es relevante si recordamos que, como se ha argumentado, este tipo de agrupaciones residenciales han tenido un papel fundamental para la organización social de las comunidades indias de Mesoamérica, especialmente en el sistema de organización ceremonial, el cual en muchos casos parte de esta estructura.

El pueblo-cabecera de Atlahuilco se ubica en la ruta Tequila-Tehuipango, camino de terraceria que iniciando en Tequila, toca las cabeceras municipales de Atlahuilco, Tlaquilpa, Astacinga y Tehuipango. Se asienta en un angosto valle, el único espacio plano -de dimensiones significativas- dentro del territorio municipal. La organización y distribución de sus asentamientos evocan una perspectiva inversa a la de un panopticon, y similar a la de un anfiteatro, cuyo centro es el valle, punto de confluencia del conjunto de pequeñas localidades que lo rodean. Los caseríos y congregaciones ubicadas en este espacio municipal, 
compuesto casi totalmente por elevaciones, lomerios y cañadas, se distribuyen hacia arriba de la cabecera. Alejarse de ella para trasladarse a cualquier otro punto del municipio, implica ascender, a veces penosamente, y encontrar mirando hacia abajo- el plan en el que destaca la cúpula del templo, la cancha de futbol rodeada de una docena de aulas escolares, el cementerio y las oficinas del ayuntamiento. Desde el centro del valle se percibe nitidamente el papel de este poblado como punto de confluencia de los residentes de las cumbres y elevaciones.

Existen en el municipio 28 subáreas o subdivisiones, cada una con un nombre especifico, cuyo número de habitantes oscila entre 60 y 350 , con excepción del pueblo-cabecera, donde residen 800 personas y la congregación Zacamilola, donde habitan 880 . Es decir, casi el 80 por ciento de la población se encuentra distribuida en asentamientos pequeños, pero claramente delimitados. Aún dentro de éstos, existe una toponimia que enfatiza las subdivisiones internas considerando los sitios de ubicación de cada una de las unidades domésticas. Además de depender administrativamente del pueblo-cabecera, en términos generales la mayoria de los habitantes de estas localidades participan simultáneamente dentro del ciclo ceremonial, cuyo centro de organización es el templo principal, ubicado en la cabecera municipal.

Localidades del municipio de Atlahuilco:

Atlahuilco

Abaloma

Acultzinapa

Atetekochko

Atezoc

Atlahuilapa

Atlehuaya

Cuautlamanca

Macuilquila

Ocotempa

Ocotlalapa

Ocotlamanca

Quchulingo

El Rincón

Tambola
Tepexititla

Terrero

Tikonka

Tlalmorado

Tlaxcantitla

Tlalxitla

Uitziquiapa

Vista Hermosa

Xibtla

Xochitepec

Zacamilola

Zacatla

Zacatlamanca

Zihuateo

Una caracteristica de esta organización en pequeñas localidades es la de ser unidades socialmente incompletas. Este sistema de agregación implica que algunos aspectos de la vida social del paraje se realicen en el nivel de organización siguiente. Por ejemplo: Tambola, paraje integrado por ocho grupos domésticos, recurre a Tepexititla, congregación que cuenta con alrededor de 35 
grupos familiares, para conseguir un acceso a los primeros años de la educación escolar para sus hijos. Pero los egresados del tercer año de primaria deben trasladarse a Atlahuilco, el pueblo cabecera para concluir la primaria, y en su caso, ingresar a la Telesecundaria. Si desean continuar con sus estudios se trasladarán al vecino pueblo de Tequila, a unos cuantos kilómetros de distancia.

Según testimonios de habitantes de la cabecera, hasta hace cuatro o cinco décadas, la organización del municipio de Atlahuilco se ajustaba al tipo de organización del modelo del centro-cabecera casi como un "pueblo vacio", y los parajes o segmentos como unidades sociales que mediaban la relación entre los hogares y la comunidad representada por el municipio (Cancian, op. cit.: 216). Los varones adultos de los segmentos prestaban servicio al municipio, en forma de "faenas" o "tequio", segun dispusieran las autoridades municipales, pero también asumian los cargos civiles y religiosos de acuerdo a las designaciones del grupo de principales o Consejo de Ancianos. Cuando era necesario, los responsables de asumir estas obligaciones, concebidas como servicio al pueblo, permanecian en la cabecera del municipio, donde contaban con un espacio para su residencia temporal que podia ser una habitación ubicada a un costado de la iglesia, el local de la comandancia o bien una vivienda de muros de madera y techo de zacate, construida por el interesado para permanecer en el pueblo el tiempo requerido. Poco a poco se volvió común levantar casas en el centro del pueblo, las cuales se utilizaban también como almacenes de granos, carbón o madera cuando los propietarios debian trasladar estas mercancias hacia fuera el pueblo. Algunas familias se ubicaron en este espacio con la pretensión de encontrarse más cerca de los servicios que éste proporcionaba.

No obstante que pareciera que no existen reglas fijas en cuanto a los patrones de residencialidad, aquí como en otros puntos de Mesoamérica, el grupo doméstico constituye una estructura latente en acción. El concepto "casa", propuesto por Sandstrom (1997) para los nahuas del norte de Veracruz, puede ser útil también para comprender el tipo de residencialidad de los nahuas de la zona fria de la sierra de Zongolica.

Este concepto implica la conjunción de aspectos materiales e inmateriales: la casa es el nexo entre las actividades que desarrollan personas que pueden o no ser parientes, puesto que es una agrupación que se basa tanto en el parentesco por descendencia como por afinidad. La casa tiene atributos contradictorios: se basa en la descendencia y en la afinidad, la endogamia y la exogamia operan a distintos niveles, los principios patrilineales y matrilineales se encuentran presentes. Sin embargo, la naturaleza social y politica de la casa, neutraliza estas contradicciones: la propiedad común de la tierra y de la casa provee de la motivación para que sus miembros se esfuercen por sostenerla a través de las generaciones.

Me interesa señalar, por tanto, que en el caso de los nahuas de Atlahuilco, 
aparece la dimensión que caracteriza a "the house societies" según LeviStrauss (cit. en Sandstrom, op. cit.: 19): una membresia dual: filiación y residencia, una confluencia de oposiciones. Esta caracteristica de esta unidad social posibilita que un grupo de personas que pueden ser o no parientes, compartan el interés común en la propiedad del espacio residencial, e interactúen entre si y hacia fuera como si fueran parientes (ibid.) El recién llegado al grupo familiar se inserta en los roles del mismo asumiendo categorias de parentesco: si es una nuera, será considerada como hermana por parte de sus cuñadas y cuñados y como hija por parte de sus suegros. Ello se presta a confusión cuando -en Atlahuilco- al preguntársele a una mujer cuál es su relación de parentesco con la madre de su marido, con quien comparte la residencia ella responde: "es mi mamá". Sin embargo, el marido de esta mujer se referirá a los padres de ella como ""suedros", dado que éstos habitan en otro sitio residencial.

Arizpe señaló que entre los nahuas de la sierra de Puebla, en la zona de Cuetzalan, "la familia como categoria basada exclusivamente en lazos de parentesco no juega ningún papel dentro de la estructura social" (1973: 156). Incluso afirma que la identidad social individual se gesta en el grupo de residencia. Una persona pasa a ser reconocida socialmente como "el yerno de" o "la nuera de" en el momento en que asume una residencialidad en el sitio de su cónyuge, reconocimiento que se sobrepone al de su grupo de orientación.

El resultado más evidente de este tipo de agrupaciones residenciales, es un sistema toponímico que permite diferenciar cada uno de los niveles de adscripción residencial, bajo un esquema de circulos concéntricos en el cual la casa o espacio residencial es la unidad minima. Por ejemplo, el sitio de un grupo doméstico -ya sea familia extensa residencial o familia extensa no residencial, siguiendo la terminologia de Nutini- ${ }^{1}$ recibe el nombre de Manzanostla, (lugar donde hay manzanas), dicho sitio se ubica a su vez en el paraje llamado Xibtla, del poblado de Zacamilola, congregación perteneciente al municipio de Atlahuilco.

Según Sandstorm, quien describe un sistema similar entre los nahuas de la Huasteca Veracruzana, lo relevante de este sistema de toponimia es que permite que parientes y no parientes se identifiquen por un mismo topónimo, el de su espacio residencial, permitiendo de este modo incorporar en una misma categoria de roles sociales a los miembros de la casa. Es decir se trata de la utilización de un lenguaje de parentesco para crear grupos sólo parcialmente basados en el parentesco (op. cit.: 22). En el sostenimiento de los vinculos entre los miembros del grupo residencial, resulta mucho más relevante la colaboración

\footnotetext{
Nutini denomina Eamilia extensa residencial al conjunto de dos o más tamilias nucleares que comparten residencia y consumo, y familia extensa no residencial a dos o más Eamilias nucleares que establecen grupos domésticos independientes dentro de la vecindad, relcionadas por lazos de consanguinidad y/0 afinidad $y$ que coupan un área residencial bien definida. (1974, 344).
} 
en el trabajo con miras a la manutención conjunta de la casa, que los lazos mismos de parentesco. Según Sandstrom, entre los nahuas de la Huasteca Veracruzana, las actividades productivas generan vinculos mucho más fuertes que aquellos basados en grupos de descendencia.

En Atlahuilco, el ciclo de desarrollo del grupo doméstico generalmente incluye una etapa de residencia patrilocal por la linea masculina, durante los primeros años de vida conyugal, etapa durante la cual se prolonga la tutela patriarcal hacia la joven pareja. Después de un periodo variable de tiempo, ésta construye su techo y fogón en un espacio cedido por el padre del cónyuge para tales fines, generalmente en las inmediaciones de la casa paterna, o en un solar contiguo (Rodriguez, 1993 y 1995b.) "Hacer lumbre aparte" es una expresión común entre los nahuas serranos para denominar esta etapa de fisión del grupo doméstico. Este hecho no siempre implica el dejar de compartir el resto de un espacio donde se ubican puntos de acceso común: el baño, el huerto, el jardin de plantas condimenticias, alimenticias, rituales y medicinales, el lavadero y los corrales de animales de crianza.

Este complejo conforma un tipo de residencia patrivecinal donde conviven la pareja de mayor edad con su prole aún sin descendencia y los hijos varones con sus respectivas descendencias. Se asume que el hijo menor o "xocoyote", permanecerá en la casa de los padres, aún con su prole, y heredará su solar y menaje de casa cuando ellos mueran. Cada nueva pareja que se conforma recibe generalmente un espacio para construir su vivienda, la cual le es cedida por el padre del cónyuge, asi como una fracción de terreno para cultivar, cuya extensión, calidad y ubicación depende de las posibilidades del padre del cónyuge. Existen sin embargo casos de uxorilocalidad y numerosas excepciones en cuanto a la tendencia de la residencia indefinida del hijo menor en la casa paterna (Rodriguez, 1993). En este sentido, me parece acertada la posición de Taggart (1975: 347), quien señala que determinados tipos de desviaciones en cuanto al comportamiento ideal de las familias extendidas es una condición permanente de las mismas, pero en ciertos casos, pueden estar relacionadas con factores vinculados a cambios socioculturales rápidos.

Es frecuente que en las áreas centrales de las cabeceras municipales predominen las viviendas separadas de los campos de cultivo, mientras que en los parajes y rancherias las unidades residenciales se establecen en contigüidad a las parcelas y extensiones boscosas. Según mi observación, en el centro del pueblo-cabecera de Atlahuilco se presentan casos de neolocalidad sin haber pasado por periodos de residencia en la casa paterna, mientras que en los parajes no se presenta este tipo de residencialidad y los periodos en el espacio patrilocal tienden a ser más prolongados (ibid.).

La mayoria de las viviendas son construcciones de madera, con piso de tierra apisonada y techo a dos aguas (de zacate, tejamanil, lámina o teja de barro 
cocido). Aunque las familias mestizas cuentan con estufa de gas, toda la población utiliza cocinas de humo, con fogones a ras del suelo en los parajes más alejados del centro, o ubicado en braceros cuadrados rellenos de tierra y de aproximadamente un metro de altura. Casi siempre se cuenta además con otra habitación más amplia, que se denomina santohkalli (casa de los santos), la cual se usa como dormitorio, adoratorio y almacén del maiz cosechado.

Sin embargo, en algunos hogares se dispone de una sola habitación, en la que se cocina y se duerme, aunque se considera deseable contar con un santohkalli, espacio destinado también a la recepción de los invitados en los compromisos de carácter ceremonial. Aún cuando no exista el adoratorio expresamente construido para las ceremonias relativas a las mayordomias y al ciclo de vida, cada hogar cuenta con un pequeño altar donde se colocan algunas imágenes de santos, presencia indispensable en el hogar. En este altar se guardan los granos de mazorca que se utilizarán para sembrar en el siguiente ciclo agricola, hierbas medicinales, huevos, copal y otros enseres de uso ceremonial.

La constucción del santohkalli generalmente ocurre después de algunos años en que se realizó el proceso de fisión del grupo doméstico, es decir, que se hizo "lumbre aparte". Durante la fase inicial de la vida como familia nuclear, la nueva pareja construirá una única habitación. La presencia de un sólo santohkalli en el espacio patrivecinal simboliza la permanencia del vinculo de producción y consumo con el resto de los miembros de la unidad residencial. Contar con un santohkalli propio representa la conclusión de un periodo en el ciclo de desarrollo del grupo doméstico y al mismo tiempo, la adquisición de un estatus social que se expresa mediante la celebración de una fiesta de mayordomia. La fiesta de mayordomia es también una forma de sacralizar el espacio doméstico recièn construido, de ofrendar el esfuerzo de su instalación a las entidades sagradas que protegerán, a cambio, a sus moradores.

Las distintas fases del ritual del matrimonio en Altahuilco, constituyen un marcador simbólico de las etapas por las que atraviesa la pareja desde el momento en que se inicia su vida conyugal. Se lleva a cabo una primera celebración en el momento en que la joven abandona la casa paterna para irse a vivir al sitio de los padres del marido. En esta ceremonia el grupo doméstico del novio entrega a sus suegros una serie de obsequios (fruta, pan, chocolate, licor, cerveza, azúcar y refrescos) y ofrece un banquete y un baile en el hogar paterno de la muchacha. Años después se realiza la boda propiamente dicha, ante el registro civil y la iglesia, cuando la nueva familia se ha consolidado económica y socialmente, cuenta ya con varios hijos $y$ se ha independizado del grupo doméstico del varón.

En algunos casos, la fase de residencia en la forma de familia extendida aglutina a más de una nuera con sus hijos y su cónyuge, y permanece hasta el momento en que se considere pertinente. Es frecuente que la pareja de mayor edad 
controle y distribuya el ingreso aportado por cada miembro del grupo doméstico y se tome la atribución de decidir en qué momento cada uno de sus hijos debe establecerse de manera independiente. Se maximiza de este modo el aprovechamiento de la fuerza de trabajo de los miembros del grupo doméstico. Sin embargo resulta una opción temporal, que cederá el espacio sucesivamente a los miembros más jóvenes y su respectiva descendencia. La pareja de mayor edad nunca estará sola; alguno de los hijos casados -generalmente el menorpermanecerá indefinidamente en la casa paterna hasta el deceso de los padres, heredando su solar y menaje de casa. Actualmente, en Atlahuilco la problemática ligada a la tierra y las presiones demográficas, propician que en la cabecera municipal un gran número de grupos familiares compartan un espacio patrivecinal cada vez más reducido.

En el siguiente capitulo abordaré la polémica relacionada con las distintas posturas e interpretaciones teóricas que se han desarrollado en relación a los sistemas de cargos y las jerarquias civico-religiosas, así como las maneras en que se ha ligado esta discusión con la noción de la comunidad indigena y sus agrupaciones residenciales. 


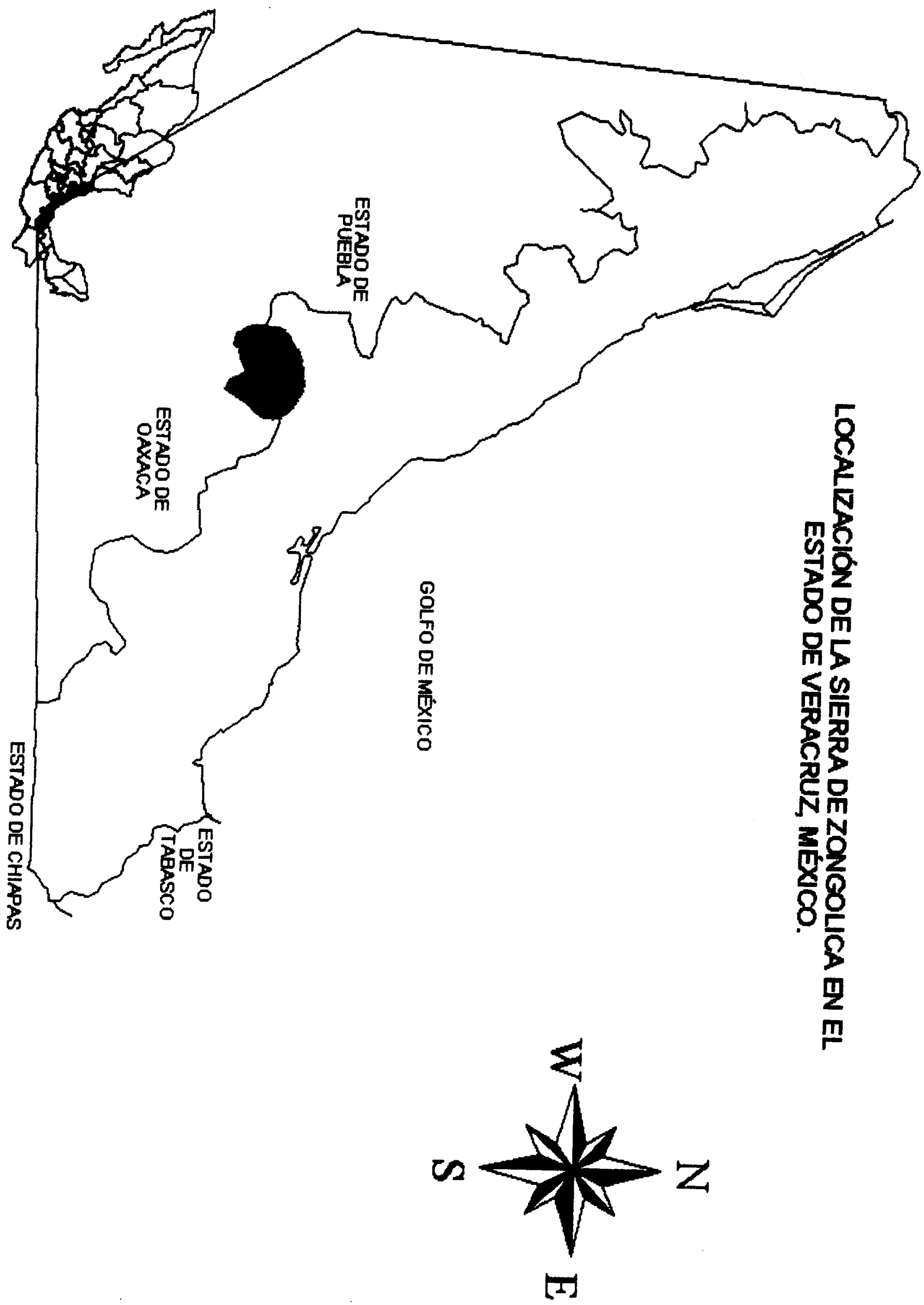




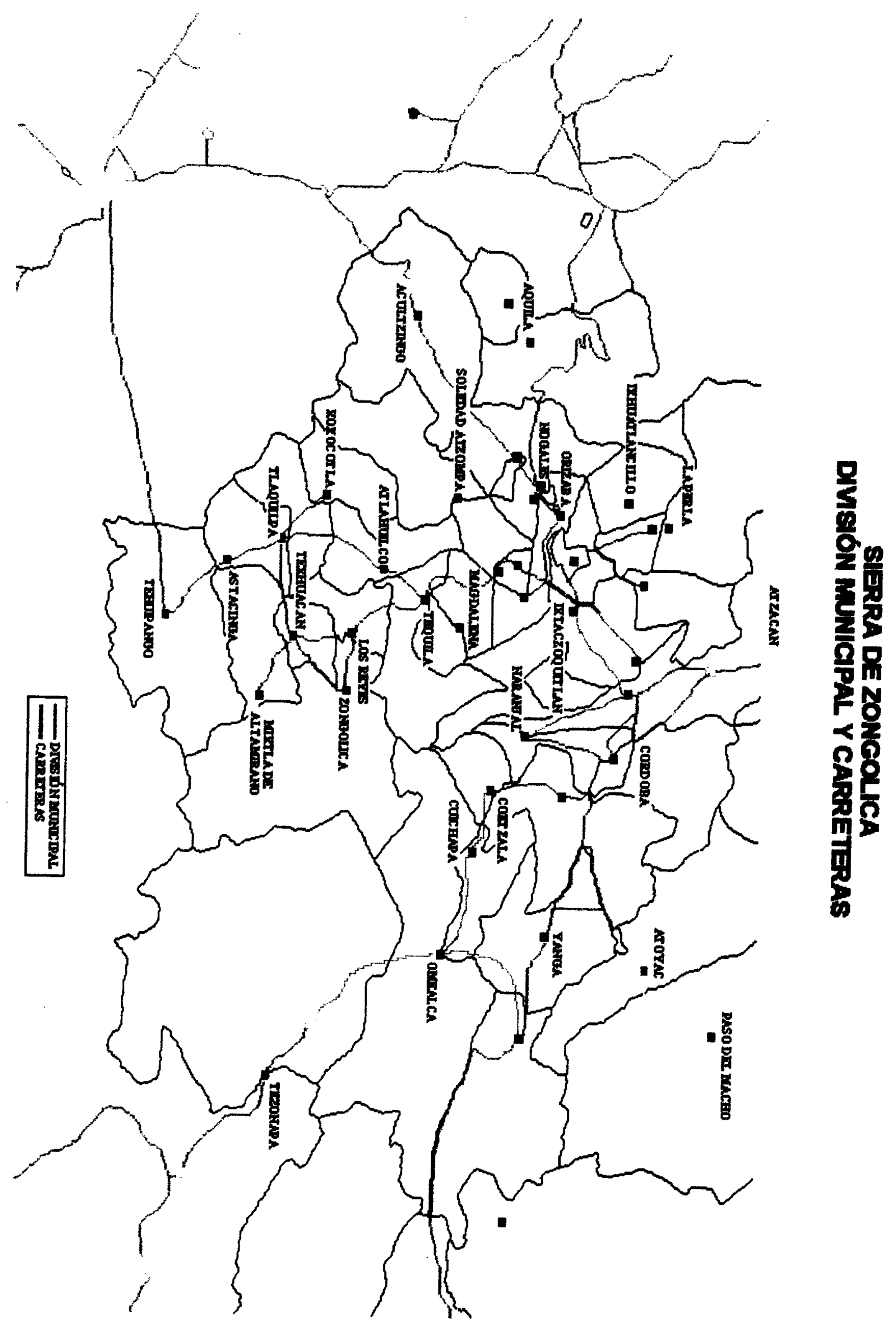




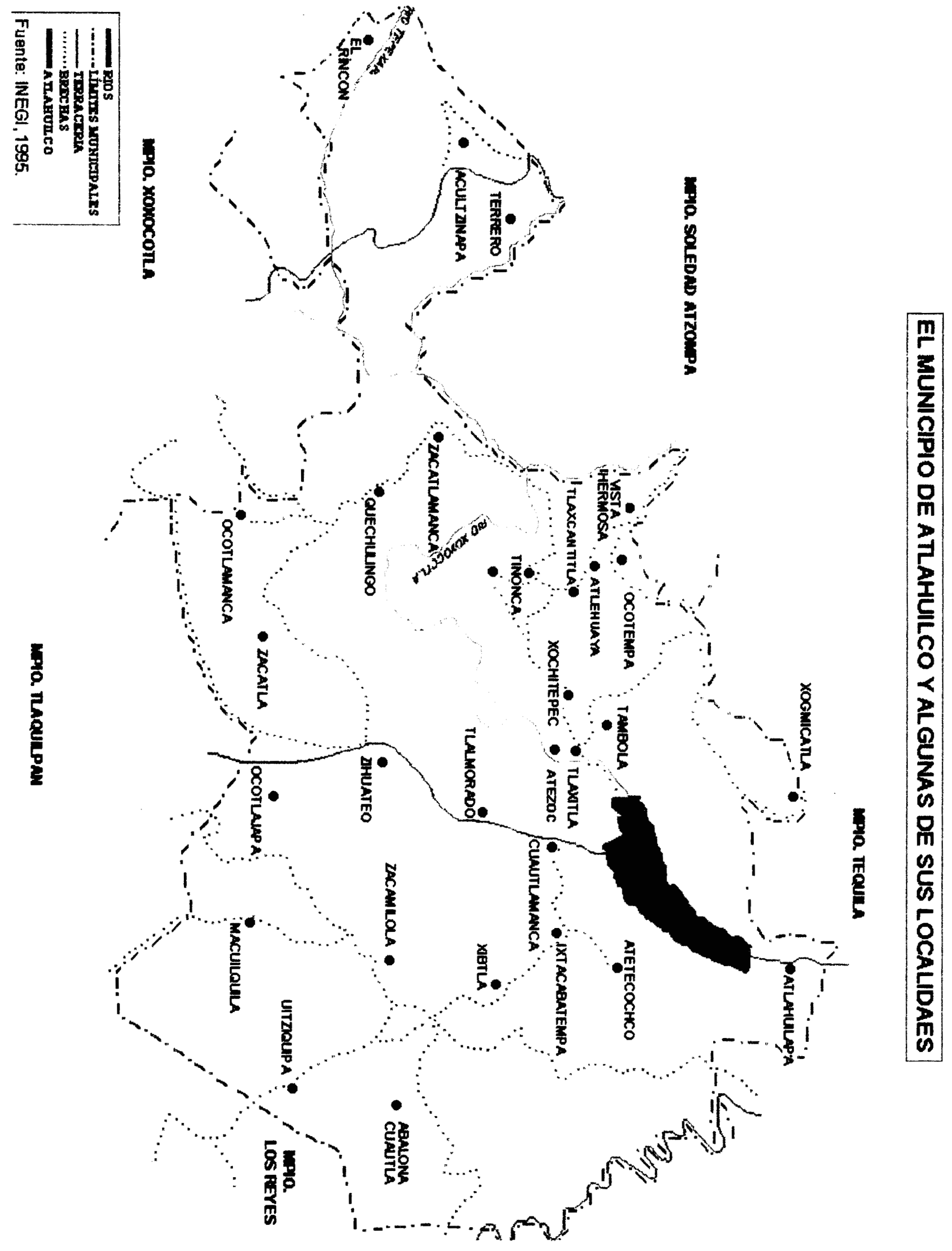




\section{CAPITULO II}

\section{EL SISTEMA DE CARGOS Y LA COMUNIDAD INDÍGENA.}

El objetivo de este capitulo es presentar las principales vertientes de la discusión teórica en relación a los sistemas de cargos o jerarquias cívico-religiosas. Me propongo plantear el desarrollo del debate que ha tenido lugar desde fines de la primera mitad del siglo XX, con la intención de discutir acerca de la perspectiva que pueda ayudar a esclarecer la vigencia de las mismas para interpretar dicha institución en las condiciones particulares en que se desenvuelve hoy en dia, y de acuerdo con el material etnográfico que se presenta en los próximos capitulos.

Como es sabido, el análisis del sistema de cargos, de fiestas o de mayordomía como se conoce a la "jerarquia de comisiones de distinción establecida que, en su conjunto, abarcan la administración pública, civil y religiosa de la comunidad" (Chance y Taylor, 1987, cit. De Walt, 1975), ha ocupado un lugar central en numerosos estudios acerca de las poblaciones indigenas de México y Guatemala a partir de los años cincuenta del siglo XX, los cuales seguirian la ruta trazada por Sol Tax a partir de la publicación de su investigación sobre Guatemala en 1937. La adopción de la comunidad como universo de estudio se constituiria en un referente básico que quedaria indisolublemente ligado al paradigma de los sistemas de cargos. Este modelo de análisis que presupone un supuesto aislamiento de la comunidad indigena, la cual mantiene su estructura fundamental a través de las visicitudes históricas, manifiesta una evidente influencia de la teoria funcionalista.

La aldea o municipio, como unidad social y cultural básica constituyó el concepto de comunidad que sostuvo a gran parte de los estudios que se desarrollaron durante varias décadas, aún cuando se plantearon distintas posiciones en relación a las funciones y la relevancia de los sistemas de cargos . Dentro de este marco analitico, se consideró al sistema de cargos como la institución que abarcaba la estructura social del municipio y por tanto, representaba el nivel más amplio de la integración entre sus habitantes. Como señala Korsbaek (1996: 36) esta tendencia trajo como consecuencia que durante varias décadas se renunciara a realizar trabajos etnográficos desde una perspectiva regional, o incluso a nivel del paraje o localidad más pequeña.

Al tomar al municipio como marco de referencia para el funcionamiento de la jerarquia civico-religiosa, el sistema de fiestas o el sistema de cargos, se destacaba su importancia al mantener los vínculos entre los habitantes de cada una de las unidades territoriales ubicadas dentro de los limites de la comunidad asi concebida. El sistema de cargos se interpretó como una forma capaz de organizar las instancias de las unidades domésticas y de las organizaciones intermedias; a través de dicha interacción se expresa el poder regulador del 
sistema de cargos, en términos del control de las comunidades sobre su territorio en sus dimensiones politicas y sociales (Carmagnani, 1988: 183-225).

En el fondo de estas interpretaciones, subyacia la influencia del pensamiento de Ferdinand Tönnies, filósofo alemán de fines del siglo XIX que establecia una conceptualización básica respecto a los principios de las relaciones sociales: la oposición entre la vida en comunidad, Gemeinschaft y la vida en sociedad, la Gessellschaft. La primera sería el estado natural, la unidad perfecta de la voluntad humana, cuya unidad de sangre mantiene una inmediata expresión en las formas de convivencia y en las cuales existe una inclinación al consenso.

"toda vida de conjunto, intima, interior y exclusiva, deberá ser entendida, a nuestro parecer, como vida en comunidad" (1947: 20)... "Vida comunal es posesión y goce mutuos, y es posesión y goce de bienes comunes. La voluntad de poseer y gozar es voluntad de proteger $y$ defender" (p. 43).

Para Tönnies, la comunidad se basa en el consenso de las voluntades; las tradiciones y las costumbres conforman un código que regula las relaciones entre estas voluntades. Mientras que en la sociedad o gessellschaft los hombres, si bien se encuentran pacificamente organizados, no están "esencialmente unidos, sino esencialmente separados" y en estado de tensión permanente hacia los demás; la unión entre ellos es arbitraria. La comunidad se rige por la voluntad esencial, la sociedad por la voluntad arbitraria; ésta distinción se expresa según Tönnies, entre otras antinomias, en la oposición entre las formas juridicas de status con respecto a las de contract. (op. cit.: 234). Es decir, mientras que en la primera el orden social se basa en el acuerdo de voluntades y es consensualmente establecido, en la segunda es necesario realizar una especie de pacto, salvaguardado mediante las leyes y los contratos, un orden juridico que se yergue por encima de la sociedad y consigue imponer un juicio supuestamente imparcial y objetivo.

Los acercamientos teóricos hacia las poblaciones indigenas de México como objeto de estudio, encajarian pues en la esencia del concepto de comunidad propuesto por Tönnies, el cual implicaba concebir la vida de los indigenas dentro del esquema de la Gemeinschaft. Se consideró a la comunidad como el objeto de estudio por excelencia de los antropólogos, entidad aislada en el tiempo y en el espacio y al sistema de cargos como su experiencia cultural fundamental. A partir de la teoria de la comunidad de Ferdinand Tönnies, los antropólogos de la escuela de Chicago y el proyecto Harvard, incorporaron dicha propuesta en su interpretación de las relaciones sociales en el contexto indigena. Estos trabajos no consideraban la presencia del conflicto y la estratificación social y cultural al interior de los pueblos indios. Por otra parte, se asumia implicitamente una especie de intención consiente de los indigenas de permanecer bajo el esquema de la communitas, sin reconocer que dentro de estos espacios se expresaba también una especie de copresencia de tiempos y de intenciones, la cual 
matizaba la aparente dicotomia entre la communitas y la societas. Es decir, estas interpretaciones ocultaban el hecho de que la situación marginal de los pueblos indigenas se debía a los mecanismos de exclusión gestados desde el seno de la societas y no a partir de un supuesto equilibrio emanado de la propia communitas.

No solamente Tönnies influiria en esta concepción antinómica de las sociedades humanas; el pensamiento de Emile Durkheim y Max Weber también influenciaba las obras de los cientificos sociales de principios de la segunda mitad del siglo XX. Durkheim concebia a las sociedades simples bajo una organización que denominó solidaridad mecánica, cuya cohesión estaba fundamentada en factores de carácter moral, tradicional y familiar. Las sociedades complejas, según este autor, estaban regidas bajo estructuras normativas $\mathrm{e}$ instituciones que reglamentaban el comportamiento de los individuos, éstos quedaban agrupados bajo principios de solidaridad orgánica, explicitamente concebidos para conseguir el orden en el funcionamiento de las relaciones sociales.

Bajo estas influencias se desarrollaban los estudios que se interesaban en dilucidar las características de la comunidad indigena del área mesoamericana. El sistema de cargos civico-religiosos fue interpretado como un mecanismo que influía decisivamente en la manutención de la homogeneidad y estabilidad comunitaria, puesto que su funcionamiento menguaba las posibilidades de conflictos. Es decir, en términos generales la polémica relativa a esta institución ha estado, desde sus inicios, matizada por este conjunto de implicitos en los cuales subyace un enfoque organicista de carácter funcional. De acuerdo a los palnteamientos de Radcliffe-Brown (1975: 61), uno de los principales teóricos de esta corriente, el método funcional de interpretación supone que toda cultura es un sistema estructurado donde cada elemento desempeña un papel determinado. Dado que Sol Tax fue discipulo de Radcliffe-Brown (Medina, 1996:15), la influencia de su maestro se apreciaría en su célebre ensayo sobre el sistema de cargos en Guatemala, publicado en 1937, en el cual se analiza por primera vez esta institución. A partir de entonces, ésta se convierte en el objeto de estudio privilegiado de una serie de investigaciones posteriores, en las que subyace el enfoque de la antropología social británica.

No obstante, se han desarrollado distintas posiciones tanto en relación a las funciones e importancia de las jerarquias civico-religiosas o los sistemas de cargos, como en cuanto a sus origenes. Según la sintesis presentada por Chance y Taylor (1987), es posible distinguir por lo menos cuatro generaciones en los estudios sobre la jerarquía civico-religiosa mesoamericana. La primera de ellas corresponde a los trabajos en los cuales se estableció por primera vez la estructura general del sistema, de entre los cuales destaca el realizado por Sol Tax en los Altos de Guatemala -publicado en 1937-, quien marcaria la pauta para subsiguientes estudios que tomaron como marco de referencia a la 
comunidad.

Para Sol Tax (1996: 89-100), comunidad y municipio son categorias homologables: las divisiones territoriales administrativas en las comunidades mayas correspondian a las divisiones étnicas básicas. Estableció que el criterio lingüístico no podia ser utilizado para designar a un grupo étnico, sino que la correspondencia entre divisiones lingüisticas y divisiones culturales debia determinarse en cada caso. La gente de Guatemala, dice, vive en municipios que constituyen las divisiones étnicas básicas y los grupos culturales en que está dividido el pais. En cada municipio existe una jerarquia de cargos seculares y una jerarquia paralela de funcionarios religiosos; cada uno de ellos realiza sus celebraciones religiosas de acuerdo a su calendario particular, asi mismo, tiene su respectiva fiesta titular, la cual se lleva a efecto con variaciones de un municipio a otro.

Después de los años cincuenta, se sistematizó esta jerarquia y se analizó como la escencia de los comunidad indigena, con las investigaciones de Cámara (1952), Nash (1958) y Wolf (1959). Fernando Cámara ([1952]1996: 114) coincidiria con Sol Tax al homologar la categoria de comunidad a la de municipio, unidad social y cultural en las comunidades de Mesoamérica. Caracterizó a éstas como organizaciones centripetas, dado que su estructura se orienta hacia la conservación de un orden de naturaleza tradicional, homogéneo, colectivista e integrado, en el cual el bienestar de la comunidad se antepone al del individuo. Para Cámara las organizaciones centrifugas son heterogéneas y cambiantes y es en ellas más importante el bienestar de los individuos que el de la colectividad; los estimulos culturales se seleccionan y modifican de acuerdo a los intereses individuales o familiares. La organización religiosa y política en las comunidades centripetas, se realiza mediante la cooperación y ayuda de todos los miembros y bajo un principio jerárquico. Los ideales de honradez, buen juicio y solvencia económica contrastan con los deseos de intereses personales y de mejora económica de las comunidades centrifugas. En estas últimas, el concepto de comunidad no es equivalente al de municipio: la comunidad se reduce a la gente que habita en la cabecera; no existe una correspondencia en la identificación del grupo cultural con los limites administrativos municipales.

También Manning Nash ([1958]1996: 165) percibió que la organización municipal en las comunidades indias constituia una estructura que vinculaba a la comunidad local a la nación, mediante una jerarquía civil y una religiosa estrechamente articuladas. Con base en su estudio realizado en Guatemala, apuntó que la operación de esta jerarquia definia los límites y número de miembros de cada comunidad y era el medio para mantener unidas a todas las familias del municipio. Esta jerarquia representaba un mecanismo para "tabular" el consenso en torno a asuntos de diversa indole: politicos, legales, económicos, etc.; pero también mantenia las relaciones de la comunidad con lo sobrenatural, cuidando de la celebración a los santos del calendario religioso y 
del santo patrón. Nash introduce la idea de los efectos niveladores del sistema de cargos civico-religiosos: éste funciona como un freno hacia la distinción de clases, mantiene una homogeneidad social y media en las relaciones entre la sociedad local y la nación. Equiparó la importancia de los sistemas de cargos en las comunidades indigenas con el papel del parentesco en las sociedades africanas.

Eric Wolf analizó la institución como un mecanismo nivelador de las diferencias de riqueza al interior de la comunidad indigena, como una forma de combatir la acumulación individual que podia poner en riesgo el equilibrio económico comunitario. De modo que al limitar la autonomia individual y conseguir que todos los miembros participen por turno en los asuntos del gobierno, se garantiza que sea el cargo el que gobierne y no la persona que lo ocupa; de esta forma se evitan conflictos y se orienta el trabajo de todos en favor de los intereses colectivos. (1986, 192-193). Caracterizó a las comunidades indias de Mesoamérica como "comunidades corporativas cerradas" (1977), en las cuales la calidad de miembros de la misma se encuentra restringida a quienes han nacido y crecido dentro de sus limites, estableciendo barreras a la integración de forasteros y a la capacidad de sus miembros para relacionarse con los miembros externos a su sociedad. Caracteristica fundamental en la organización interna de este tipo de comunidades, es la redistribución de los excedentes mediante la participación en el sistema religioso y la adquisición de prestigio social al ocupar los cargos religiosos jerarquizados. La unidad básica de la vida es la comunidad, no el individuo. En el planteamiento de Wolf aparece una coincidencia notable con la posición de Sol Tax en cuanto a la consideración de que la comunidad indigena consiste en un sistema económico, lingüístico y politico relativamente autónomo, en una dinámica de aislamiento social y cultural de la sociedad mayor. Estas sociedades, dice Wolf, existen porque sus funciones son contemporáneas (op. cit.: 92).

Estos planteamientos tuvieron en común -como lo señalan Chance y Taylor (op. cit.:2)- el asignar a los sistemas de cargos un efecto igualador sobre la riqueza individual, el de constituir el canal más aceptable para el desempeño personal y funcionar como mecanismo de defensa y protección frente al exterior.

Después de los estudios pioneros realizados en Guatemala, se puso en marcha el proyecto Harvard en los Altos de Chiapas a cargo de Evon Z. Vogt. Este grupo de investigadores norteamericanos realizó aportaciones significativas al conocimiento etnográfico sobre los sistemas de cargos y las jerarquia civicoreligiosa, especialmente a través de los trabajos de Frank Cancian (1976), Victoria Bricker (1966), George Collier (1976) y el mismo Evon Z. Vogt (1966). Para este momento el interés fundamental es establecer si realmente las jerarquias civico-religiosas nivelan las diferencias económicas, si constituyen una defensa o son un instrumento diseñado por la sociedad dominante para sojuzgar y explotar a la población indigena (Chance y Taylor, op. cit.; 3). 
Cancian cuestionó la interpretación de los sistemas de cargos civico-religiosos como niveladores de la riqueza. En su estudio sobre el sistema religioso de cargos en Zinacantan, pueblo tzotzil de los Altos de Chiapas, demostró que el sistema legitima las diferencias económicas y la estratificación interna de la comunidad. Apuntó que su importancia reside en la generación de un sistema normativo que exige de los individuos el servicio a la comunidad y refuerza continuamente una serie de valores comunes. Para Cancian la institución es eminentemente integradora; enunció que a medida que los zincantecos aventajaran en número la disponibilidad de los puestos, sus excedentes económicos no podrian seguir intercambiándose por prestigio a través del sistema de cargos religiosos y éste dejaria de cumplir su función integradora. Evon Z. Vogt (1976), al prologar la obra de Cancian, pronosticó que el aumento de población en las comunidades de los altos de Chiapas, conduciria a escisiones que determinarian el desarrollo de sistemas de cargos adicionales. En esta interpretación se vislumbraba ya un interés muy claro por incorporar una visión del cambio y las transformaciones del sistema de cargos y por cuestionar la idea de sus funciones niveladoras; se señalaba que una creciente riqueza 0 una agudización de las condiciones de pobreza repercutirian sensiblemente en la reproducción del sistema. Sin embargo, se trata aún de una visión funcionalista, que considera que el sistema de cargos es un sistema normativo que exige de los individuos la participación plena en beneficio de la colectividad.

Posteriores trabajos ilustrarian sobre una diversidad de modalidades de los sistemas de cargos en situaciones etnográficas especificas: formas de financiamiento individuales o colectivas, escalas de puestos combinando cargos civicos y religiosos, escalas meramente religiosas, el papel de las condiciones externas en el funcionamiento del sistema, su importancia como mecanismo de cohesión social, etc. Sin embargo, parece haber surgido el acuerdo de que la hipótesis de la nivelación no es demostrable y que tampoco es compatible con el sistema de cargos una estratificación significativa (Chance y Taylor, ibid.).

Aguirre Beltrán asignó al sistema funciones eminentemente integrativas, encaminadas a sustentar la cohesión del grupo y a defenderlo de los contactos de fuera y de sus efectos desorganizantes. En la obra de Aguirre Beltrán, al retomar algunos aportes de algunos de sus antecesores como Ricardo Pozas, Sol Tax y Robert Redfield, entre otros, modela a la comunidad india, inserta en la región de refugio, como "una sociedad sin clases sociales, organizada como un grupo de status, de indole sacra y naturaleza folk que define lo que generalmente llamamos una comunidad" (1991: 186). Su sistema de estratificación interna emerge de un patrón de homogeneidad, resultado de restricciones sociales como la endogamia, de la baja especialización técnica y de su simplicidad cultural; dicho sistema se compone de una jerarquía politico-religiosa que depende para su funcionamiento de un sistema de cargos. Este sistema, dice Aguirre Beltrán, es básico para la existencia y la continuidad de la cultura tradicional y 
constituye la base de la segregación que mantiene distintas a la sociedad ladina y la india, puesto que sustenta la cohesión del grupo y lo defiende de los efectos desorganizantes del exterior. (op. cit.: 227). Las funciones del sistema son: otorgar membresia e identificación a los habitantes de la comunidad, la redistribución equitativa de los recursos y el ejercicio de control social para el cumplimiento de las normas de conducta.

Según Aguirre Beltrán, dichas funciones contribuyen a la defensa y definición de los simbolos y valores que mantienen unido al grupo étnico, asi como a la ordenación de las reciprocidades y la redistribución económica, fundamentos que configuran su naturaleza. Pero es en relación al ejercicio del poder donde se ejerce con precisión la especificidad de la ideologia de las formas de gobierno indigena: se trata de un sistema que incluye a todos los miembros adultos de la colectividad y el ascenso en la escala del poder requiere de un gasto cada vez más oneroso a medida que se accede a los puestos más altos. El ejercicio del poder requiere de un derroche institucionalizado, que no permite la acumulación de unas familias sobre otras, sino que debe invertirse precisamente en el consumo ritual para hacer ostensible dicha riqueza y adquirir prestigio. Este mecanismo impide la acumulación de bienes y evita la formación de grupos de interés y de clases sociales, dando lugar a una comunidad socialmente homogénea e integrada. Sin embargo, el cumplimiento del ciclo ceremonial implica el consumo de una gran cantidad de bienes que provee la población ladina ubicada en las regiones de refugio, de modo que es también una forma de explotación hacia las poblaciones indigenas, ejercitada a través del comercio.

En el concepto de comunidad propuesto por Aguirre Beltrán se aprecia la influencia de la idea de la communitas desarrollada por Tönnies, al establecer su diferenciación entre una sociedad de status, refiriéndose a la india, y una sociedad de contrato, la occidental. Existe en las regiones de refugio un sistema dual que ordena la convivencia entre indios y ladinos, el cual permite la explotación de éstos sobre aquellos.

El examen de la organización sociorreligiosa en los pueblos indios se sostuvo pues, durante un largo periodo, como el centro de la vida comunitaria y en su análisis se postularon distintas posiciones en relación a sus consecuencias funcionales: de nivelación socioeconómica (Wolf, 1986), de redistribución económica (Aguirre Beltrán, 1991; Dow, 1974), como forma de adquisición de prestigio social (Pozas, 1977; Vogt, 1980; Cancian, 1976; Dehouve, 1976); como el medio de extraer riqueza de las comunidades (Harris, 1964), o como legitimación de las diferencias (Cancian, 1976).

Durante las décadas de los años setentas y ochentas se continuó generando información respecto a los sistemas de cargos en distintas regiones indigenas de México y Guatemala. En algunos de los trabajos, siguiendo la línea iniciada por Harris (1964), se enfatizaba que el sistema de fiestas extrae una considerable

\section{1}


riqueza de las comunidades. Harris planteó que esta práctica propicia la transferencia de recursos fuera de la comunidad, y es una estrategia disenada para explotar aún más a la población indigena. Me refiero a continuación algunos de los principales trabajos realizados en este periodo.

Danielle Dehouve (1976), estableció que la organización comunal de los nahuas de Guerrero descansa sobre una organización en dos barrios o mitades y un sistema de cargos -herencia colonial- que asegura el carácter corporativo. Dehouve apuntó que la entrada en el mercado nacional e internacional amenaza la homogeneidad de la comunidad indigena en términos económicos, mientras que la introducción de funciones politicas por parte del Estado mexicano, contribuye a la destrucción del sistema de cargos, y en consecuencia del propio marco comunal.

Más tarde, Catherine Good (1988) estudiaria Ameyaltepec, un pueblo nahua de la misma región guerrerense, puntualizando que el desarrollo de las fiestas dedicadas a los santos $-\mathrm{y}$ a otros eventos de la vida ritual- pone en funcionamiento un sistema de reciprocidades que contribuye estructuralmente a la cohesión de la organización socioeconómica tradicional, la cual obstaculiza la penetración de relaciones capitalistas dentro de la cultura local (p. 172). La autora señala que entre los nahuas de la rivera del Río Balsas, el comercio de papel amate pintado a mano, de cerámica y otros productos artesanales, ha hecho posible una generación de excedentes significativos entre las familias de los artesanos. El sistema de reciprocidades a través del cual se sostiene el ciclo ceremonial es una de las formas en que los pobladores emplean sus excedentes y propician la redistribución de los mismos.

El valle poblano-tlaxcalteca, en el centro de México, habitado por otro grupo nahuatlato, seria otro espacio ampliamente estudiado. Destacan los trabajos de Hugo Nutini en San Bernandino Contla y Santa Maria Belén (1968 y 1989 en coautoria con B. Bell), en la región de La Malinche. Nutini y Bell consideraron al sistema de escala como una entidad sincrética, cuya evolución es una expresión de la transformacion de las sociedades indias mesoamericanas hacia sociedades igualitarias como consecuencia de la politica colonial española.

Además de éstas, se desarrollaron investigaciones en distintos regiones de México: entre los tarascos, (Foster, 1967; Zantwijk, 1974), entre los mayas de Yucatán (Redfield, 1930 y 1962; Villa Rojas, 1939, 1985:; Farris, ) en la Sierra Norte de Puebla, (Buchler, 1967; Taggart, 1975; Arizpe, 1973; Segre, 1987), entre los nahuas de Morelos (Lewis, 1951, Redfield, 1941); entre los zapotecos de Oaxaca (Nader, 1964; De la Fuente, 1949; Millán, 1993); entre los otomies (Dow, 1975; Galinier, 1987 y 1990, Tranfo, 1975); entre los zoque-popolucas (Báez, 1973; Rubio, 1995); entre los chatinos (Greenberg, 1981); en la zona mazahua del Estado de México (Cortés, 1972); entre los tlapanecas de Guerrero (Oettinger, 1980); los popolocas de Puebla (Jäcklein, 1974); entre los nahuas de 
Huauchinango (Chamoux, 1987) y entre los huaves de la costa de Oaxaca (Signorini, 1979) . En los Altos de Chiapas, J. Nash (1975), Henri Favre (1984), Alain Breton (1984), Robert Wasserstrom (1989) y Andrés Medina (1983 y 1984), por mencionar sólo algunos de la larga lista de estudios que han tocado central o tangencialmente cuestiones relacionadas con el papel del sistema de cargos en la organización social de las poblaciones indigenas.

Uno de los aspectos más cuestionados hacia algunos de estos estudios se refiere a su perspectiva ahistórica y a la visión de las comunidades indias como entidades autónomas, es decir un trasfondo funcionalista que si bien ha sido matizado por diversos autores, ha continuado presente en la concepción misma de los sistemas de cargos como campo conceptual. En este sentido y tratando de salvar esta carencia, se han realizado diversas interpretaciones en cuanto al origen del sistema (Smith, 1981; Chance y Taylor, 1987; Wasserstom, 1989) y su desarrollo en el seno de sociedades clasistas. (Smith, 1981; Stephen y Dow, comps., 1990). La generación de "antropológos criticos" mexicanos integrada por Guillermo Bonfil, Margarita Nolasco, Salomón Nahmad y Arturo Warman, entre otros, cuestionaron el papel de este tipo de investigaciones, las cuales, desde su punto de vista, se dedicaron a construir modelos para mantener el gobierno colonial (Nahmad, 1998: 7).

Más recientemente se ha discutido este tipo de organización bajo una orientación que se propone comprender la relación entre las formas organizativas emanadas de las prácticas religiosas, el desarrollo capitalista y la formación de clases, así como las diversas maneras en que las prácticas religiosas pueden servir de base a movimientos sociales y de participación política. (Geenberg, Earle, Cancian, Chance, en: Stephen y Dow (comps.) 1990). Asi mismo, se ha introducido el análisis de la diversificación religiosa, la pastoral indigena y el conflicto político en el seno de las regiones indígenas, especialmente en estudios realizados durante la década de los noventa en el estado mexicano de Chiapas (Leyva, 1998; Hernández Castillo, 1998; Garcia Méndez, 1998; Marion, 1998; Escalante, 1998; Rivera Farfán, 1998, entre otros).

Considerando la diversidad y complejidad de los datos aportados por las distintas generaciones de estudiosos en torno a esta temática, Andrés Medina (1995: 9) subraya que las diferentes posiciones no deben considerarse excluyentes, sino fases de un desarrollo relacionado con la dinámica de las comunidades y la pluralidad de situaciones especificas. De acuerdo con Chance y Taylor (op. cit.: 19), los actuales sistemas de cargos cambian de formas distintas y novedosas, de modo que no es posible optar por una sola línea de interpretación, sino más bien considerar este tipo de sistema como un proceso que implica cambios importantes en su función, unidos a cambios estructurales significativos y con variaciones en el tiempo y en el espacio.

Como señala Diaz (1997) el análisis de los procesos sociales no debe ser visto 
como una alternativa que excluya los estudios sobre instituciones, sino como un complemento de éstos, es decir, en una continua oposición entre orden y desorden, en un flujo continuo que los dota de energia y movimiento. De ahi que se haya criticado, como se decia líneas arriba, el enfoque funcional predominante en el análisis de los sistemas de cargos, proponiendo que es necesario incorporar una visión que considere las relaciones socioeconómicas relacionadas con los procesos regionales, y de desintegración y proletarización por los que atraviesan las regiones indigenas (Medina, 1987; Smith, 1981). Asi mismo, se cuestiona la idea de que esta institución siga una única dirección evolutiva y se señala la dificultad de observar sus transformaciones estructurales desde una perspectiva funcional (Medina, op. cit.; Korsbaek, 1996). Desde mi punto de vista, es indispensable considerar estas posturas criticas para conseguir abordar el análisis de los sistemas de cargos en las condiciones particulares en las que se desenvuelven hoy en dia las poblaciones indigenas de México, condiciones que generan tanto procesos de resistencia como procesos que dan lugar a la desintegración y diferenciación internas.

\section{a) La perspectiva histórica de los sistemas de cargos.}

Otra vertiente del debate ha sido la desarrollada en cuanto a los origenes históricos de las jerarquias civico-religiosas y los sistema de cargos. En un trabajo pionero en este sentido, Pedro Carrasco (1979) planteó que la institución fue el resultado de la conjunción entre el sistema municipal introducido durante el primer periodo colonial y la organización local del culto católico popular. Carrasco señala que en el ámbito de la organización municipal colonial, existen muchas similitudes con el sistema español. Por otra parte, el autor encuentra rasgos de la organización política, ceremonial y económica precolombina que son similares al sistema de escala de la jerarquia civico-religiosa: la escala de estatus jerárquicamente clasificados, las posibilidades de ascenso en esta escala y las implicaciones económicas del sistema.

Sin embargo, Carrasco hace notar que en las sociedades prehispánicas, la situación era básicamente distinta de la que presentan "las actuales comunidades sin clases" (p. 33), en las cuales el sistema de escala cívico-religioso es un mecanismo democrático que permite que todos los miembros del grupo tomen por turno sus puestos en los cargos principales. Mientras que en las sociedades prehispánicas, las diferencias hereditarias entre la clase noble y la de los plebeyos repercutia en una restricción rigida de los cargos más altos a la clase noble.

No obstante, aunque en términos de la estructura social Carrasco encuentra grandes similitudes entre la sociedad prehispánica y la colonial, enfatiza también la existencia de un cambio radical en las formas culturales, como resultado de la introducción del sistema español de administración municipal y de la conversión al cristianismo. Estas formas españolas se reconfiguraron según los rasgos 
principales de la estructura ceremonial y politica indigena. Argumenta que se hizo especial énfasis en mantener los niveles inferiores de la organización indígena, por ejemplo, tequitlahtos $\mathrm{y}$ topiles, los cuales aún persisten en diferentes pueblos indigenas de México (entre ellos en la sierra de Zongolica).

Aunque la exigencia del estatus de noble para el desempeño de los cargos de alto rango continuó solamente durante parte del periodo colonial, otros rasgos se mantuvieron de manera más continua: el sistema de adquirir prestigio mediante el patronazgo de ceremonias y la práctica de patrocinar las fiestas religiosas ( $p$. 335). Es en el primer periodo colonial cuando se consigue el puesto de principal por individuos plebeyos que ocuparon cargos. Se mezclan de este modo los elementos indios y españoles en una estructura en la cual se elimina la nobleza y por lo tanto, su exclusividad en el desempeño de los cargos. Otro cambio importante, según Carrasco, fue la pérdida de las propiedades públicas como fuente para sostener las fiestas religiosas. Este hecho condicionó la aparición del mayordomo -término que denominaba al administrador de la propiedad comunal- como el individuo que aportaba su propia riqueza para la celebración de una fiesta religiosa.

Según la perspectiva de Carrasco y en congruencia con los planteamientos de Wolf, Aguirre Beltrán y Sol Tax, la transformación de la sociedad india prehispánica durante la época colonial, se dirigió desde organizaciones altamente jerarquizadas, hacia comunidades campesinas autónomas, igualitarias y democráticas. La relevancia del sistema de escala radicaria en el hecho de que fue éste el hilo que conectó las formas precolombinas con las formas modernas de organización politica y ceremonial. Carrasco describe al sistema como una jerarquia, en tanto se trata de una escala de cargos anuales, en la que todos los hombres de la comunidad tienen la oportunidad de ascender a los escalones superiores y alcanzar el estatus de ancianos. Esta jerarquia implica una forma de alternancia entre los cargos civiles y los religiosos hasta conseguir un puesto superior en cualquiera de las dos esferas. La participación en esta escala de servicio obligatorio responde a la necesidad de elevar el estatus social. Pero a este objetivo estrictamente de beneficio personal, se suma también un interés colectivo: compartir por turno el financiamiento de las ceremonias de la comunidad.

Eric Wolf (1986) plantearia el surgimiento de la comunidad india como una consecuencia del nuevo régimen: privados de las condiciones sociales que permitian la reproducción de las élites indigenas, las comunidades indias se constituyeron en la unidad económica, en posesión de sus tierras y con la obligación de pagar tributo a la Corona Española de manera colectiva. Esta reconstrucción de la comunidad india, descendiente directa de la comunidad reconstituida en el siglo XVII, resultó ser en la práctica tan elástica y moldeable que ha logrado sobrevivir con su configuración esencial. 
¿Pero qué características en su organización han permitido la continuidad de esta entidad social? Wolf es contundente al afirmar que ha sido su sistema politico y religioso. En cuanto a sus origenes, señala que tiene seguramente prototipos españoles en las cofradias o fraternidades religiosas de la peninsula ibérica, pero que es indudable también el elemento prehispánico, recurriendo a las crónicas de Fray Toribio de Benavente, quien aseguraba que en épocas anteriores a la Conquista, los indígenas trabajaban dos o tres años para honrar a sus idolos con festividades en las que gastaban todo lo que poseian. El sistema religioso fue entonces, según Wolf, el mecanismo que permitió el equilibrio de la comunidad india: ésta ha demostrado una firmeza sorprendente; al limitar la iniciativa individual se ha resistido a entrar en el juego que impone el orden social más amplio, en el cual los hombres luchan por el poder personal a cualquier precio.

Hugo Nutini y Betty Bell (1989) definen el sistema de escala como "una entidad sincrética", cuyo desarrollo puede ubicarse -por lo menos en Tlaxcala- en los primeros años de la etapa colonial, cuando tuvo lugar el inicio de una serie de cargos rituales y ceremoniales relacionados con la Iglesia Católica. En el siglo XVII, emerge el ayuntamiento religioso, un sistema orgánico independiente de la jerarquía católica central, al cual considera resultado de un proceso sincrético y simbólico de aculturación. Para Nutini y Bell, la etapa sincrética final del ayuntamiento religioso, surgió cuando el sacerdocio seglar sustituyó al liderazgo de los frailes. Fue entonces cuando el ayuntamiento se convirtió en "un todo orgánico en cuyo seno los cargos administrativos y ceremoniales que se habian creado en la etapa anterior, se convirtieron en partes integrantes de un sistema autor-regulador" (p. 334).

Robert Wasserstrom (1980), a partir de su trabajo etnohistórico en los Altos de Chiapas, ubica el surgimiento del sistema de cargos hacia fines del siglo XIX y principios del siglo XX, como consecuencia de los cambios económicos que sufren las comunidades indigenas una vez concluido el periodo colonial. Estas organizaron nuevas instituciones con el fin de fortalecer sus mecanismos de defensa hacia los extraños. En Chamula, los lideres de la comunidad establecieron -hacia 1914- que todos los funcionarios del pueblo debian ser elegidos de entre los ancianos, quienes consolidaron su control sobre los asuntos públicos. Para poder aspirar a la jefatura principal del pueblo, los candidatos debian haber ocupado un cargo religioso, de modo que todos los puestos estaban controlados por un grupo de hombres, los principales, quienes se encontraban en lo más alto de la jerarquia civico-religiosa. (p. 210-211).

Chance y Taylor (1987) argumentan, con base en el estudio de materiales de archivo de cuatro regiones de México, que si bien la jerarquia civil se desarrolló durante época colonial, la de orden civico-religioso constituyó un fenómeno posterior a la Independencia. Después de un análisis detallado de los enfoques e interpretaciones que se han desarrollado sobre la jerarquia cívico religiosa, asi 
como de las especulaciones en torno a los origenes prehispánicos o coloniales de este sistema, los autores plantean que es indispensable analizar por separado la jerarquia civil, la jerarquia religiosa y la institución del patronazgo individual de las fiestas, puesto que su desarrollo es a la vez independiente y correlacionado. Hacia finales del siglo XVI se desarrolló una jerarquia civil ajustada a la legislación colonial, pero no relacionada con los cargos religiosos. Estos se organizaban mediante las cofradias, organizaciones que sostenian el culto a los santos locales, es decir, según los autores, no existía una jerarquía civicoreligiosa unificada.

El patronazgo individual de las fiestas no fue durante la vida colonial un vestigio de la época prehispánica, sino una adaptación a las circunstancias políticas y económicas coloniales. La formación del sistema de cargos civico-religiosos fue una consecuencia del cambio del patronazgo colectivo al individual en las fiestas religiosas, proceso que dio como resultado las versiones de los sistemas de cargos de los siglos XIX y XX. Los cambios en el carácter de los sistemas de cargos desde la Colonia, donde funcionaban como mecanismos de control social y de expropiación, hasta los sistemas complejos en que se convirtieron posteriormente, se acentuó durante los cincuenta años posteriores a la Independencia. Desde su punto de vista, en este momento los sistemas de cargos manifiestan más interés en los asuntos del ritual que en representar a la comunidad ante el exterior. (op. cit.: 19).

Jan de Vos, al referirse a los mayas de Chiapas y Guatemala, señala que aquellos lograron llevar a cabo una "indianización" de las dos instituciones coloniales que les fueron impuestas: la cofradia y el pueblo de indios. Para los mayas del siglo XVI, dice, la cofradia fue el medio más idóneo para restablecer la cohesión comunitaria perdida y los lazos clánicos amenazados. La cofradia pertenece pues a las dos culturas y ha sido tanto instrumento de control como medio de resistencia étnica. Durante el siglo XIX, al perder la iglesia su poder institucional, los mayas tomaron en sus manos la organización de la religiosidad comunitaria y fue entonces que la cofradia cobró una importancia mayor, hasta transformarse en el sistema de cargos del siglo XX (1998: 10-13).

Para Isidoro Moreno (1985) el modelo de las cofradias étnicas andaluzas es trasplantado a las comunidades de indios. Dicho modelo funcionaba en la sociedad plurietnica andaluza desde mediados del siglo XIV, y se caracterizaba por la fusión de responsabilidades politicas y religioso-ceremoniales; al aplicarse a poblaciones indigenas pasó a ser comunal-étnico. Al mismo tiempo representa un instrumento mediante el cual el Estado impone un orden social y mantiene comunidades muy corporativizadas. De este modo, según Moreno, el sistema de cargos funciona durante la Colonia como estrategia de dominación sobre las etnias indigenas, a la par que se convierte en una estrategia de sobrevivencia de las comunidades, en un baluarte significativo de la etnicidad indigena y de resistencia frente a las demandas de la sociedad nacional. 
Andrés Medina (1995: 9-10) sugiere que la promoción individual de las fiestas es un rasgo reciente, relacionado con el trabajo asalariado y el despojo y comercialización de las tierras de las comunidades indias. La base comunitaria de los rituales y las fiestas de los pueblos de indios es anterior a dicho proceso, se finca en la continuidad del modo de vida campesino que conservó sus particularidades durante toda la etapa colonial. A través del ritual comunitario, las comunidad expresaba su identidad colectiva y legitimaba su posición politica, es decir, las instituciones politicas comunitarias se inscriben en la matriz agraria y en el complejo sistema de representaciones que rigen la vida india, como los rituales agrarios de raiz mesoamericana.

Como puede concluirse a partir del breve recuento presentado, se han generado distintas posiciones en relación a los origenes del sistema de cargos; algunas de ellas se adhieren a la idea de que éste se originó durante el periodo colonial como una estrategia ante la dominación externa, y en relación directa con la estructura de las sociedades mesoamericanas, mientras que otros autores consideran que se gestó en el curso del siglo XIX. Puede observarse, sin embargo, que en los trabajos realizados durante las últimas décadas (tanto en relación al funcionamiento del sistema, como en cuanto a sus origenes) ha dejado de plantearse la existencia de las jerarquias civico-religosas como un sistema escalonado y alternante entre la esfera del gobierno y la del culto a las imágenes de los santos. Las aportaciones más recientes evidencian que no existe más este sistema unificado; los esfuerzos se han centrado en describir e interpretar a los sistemas de cargos religiosos como jerarquias de oficios para el culto a los santos locales. El divorcio entre ambas esferas ha sido, según Chance (1990), el cambio estructural más relevante de los sistemas de cargos durante el siglo veinte, el cual implicó que las jerarquias cívico- religiosas se transformaron en organizaciones más abiertas y más centradas en los aspectos rituales. Este proceso es sintomático del incremento de la integración comunitaria a las estructuras estatales y gubernamentales.

La discusión en torno a los sistemas de cargos demuestra la complejidad del fenómeno, y la dificultad para llevar a cabo generalizaciones. La evidencia etnográfica continúa enriqueciendo la información al respecto, aportando elementos para la reflexión acerca de la continuidad de una institución cuya profundidad histórica se extiende y continúa -de una u otra forma- vigente, aún en los albores del siglo XXI.

De acuerdo con mi observación etnográfica en el municipio de Atlahuilco, el sistema de cargos no constituye una jerarquia civico-religiosa, como se detalla más adelante, sino lo que Chance (op. cit.: 40) llama un "sistema de fiestas"1, en

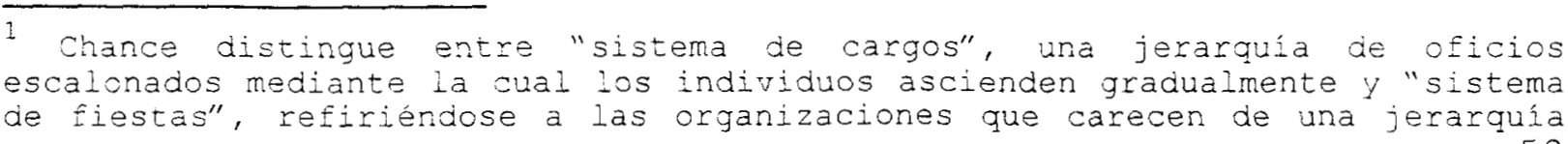


el cual el prestigio se adquiere a través del sostenimiento de las mismas en ausencia de una jerarquia fija de posiciones. Existe, no obstante, una división entre las que se consideran "fiestas grandes" y el resto de celebraciones, como se especifica en el Capitulo III. Se trata de un esquema de rotación de puestos para solventar las fiestas del calendario ceremonial, dirigidas a honrar a las imágenes de los santos que se localizan al interior del templo principal y las capillas ubicadas en algunas de las localidades. Según testimonios de algunos de los hombres de mayor edad, hasta hace algunas décadas las autoridades del ayuntamiento intervenian directamente en la asignación de las fiestas como servicio obligatorio. Sin embargo, es dificil saber si se trataba de una jerarquia estricta, es decir un sistema alternante en el cual todos los hombres debian pasar por una serie de posiciones alternantes entre la esfera civica y la religiosa. No obstante, puede afirmarse que a través de la actuación en ambas, se fincaba el valor total de la actuación de los individuos y sus grupos domésticos.

Si bien actualmente la separación entre el gobierno civil y el sistema de fiestas religiosas es contundente, la participación en el sostenimiento de éstas continua fungiendo como una fuente de adquisición de prestigio, puesto que implica la disposición de un cierto capital económico asi como de un acervo mínimo de relaciones interpersonales. En un contexto de bienes escasos, la celebración de las fiestas requiere de la imbricación de redes de apoyo mutuo entre los grupos domésticos participantes. Esta redes de intercambios reciprocos fomentan la interacción entre los habitantes de las distintas localidades que se ubican dentro del municipio, como veremos en el Capitulo IV. Por lo tanto, en este sentido es posible afirmar que el sistema de fiestas constituye un elemento de cohesión, capaz de dinamizar focos dispersos en el interior de un territorio claramente demarcado por los limites municipales.

La organización para la celebración de estas fiestas consiste en un modelo intermedio entre un sistema de comunidad amplio que se sostiene en parte mediante la participación comunal y un sistema sostenido por hogares individuales. Las festividades son realizadas parcialmente mediante la colaboración reciproca entre las unidades domésticas participantes, y en otra medida a través de la aportación estrictamente a costa del grupo doméstico responsable. El desempeño de las obligaciones rituales exige una comunidad de mayordomos lo suficientemente integrada, de manera que los fondos estrictamente individuales no representen la única fuente para el sostenimiento del sistema. Desde esta perspectiva, resulta más apropiado analizar el sistema de fiestas de Atlahuilco como un factor de cohesión horizontal que si bien otorga prestigio, su papel más relevante radica en su capacidad para generar relaciones dinámicas entre las distintas instancias socioespaciales que integran el territorio municipal.

fija en la adquisición de prestigio (1990: 40). 


\section{b) La comunidad indigena y su organización socioespacial: subdivisiones, microlocalidades $\mathrm{y}$ residencialidad.}

Dado que la estructura del sistema de cargos se explicó desde un principio, como ligada al concepto de comunidad (entendida ésta como un conjunto de unidades territoriales de diversa indole), los patrones de poblamiento fueron elemento indispensable en las investigaciones relacionadas con la organización ceremonial indigena. Aún cuando hoy en dia seria aventurado definir a los parajes, caserios, rancherias o congregaciones que integran los municipios con población indigena como linajes o clanes, desde mi punto de vista es posible afirmar -por lo menos en relación a la sierra de Zongolica- que aún constituyen un nivel de organización que no se desliga del sentido de pertenencia e interacción con una unidad mayor que casi siempre es el municipio.

Como mencioné páginas atrás, con los trabajos de Sol Tax se inició la interpretación del municipio indigena como categoria homologable a la de comunidad. Los patrones de poblamiento y la relación de éstos con el sistema de parentesco, el ciclo de desarrollo de los grupos domésticos, las formas de acceso a la tierra y la organización ceremonial, fueron temáticas que ejercieron importante atracción por su complejidad y caracteristicas de multifuncionalidad. Como veremos, el análisis del funcionamiento del sistema de cargos, permitió interpretar la organización del municipio indigena como un sistema coherente de interrelaciones entre sus componentes. Desde los estudios iniciados por la generación de antropólogos del proyecto Harvard, a cargo de Evon Z. Vogt y de la escuela de Chicago, se manifestó especial interés en la organización territorial del municipio indigena.

Los patrones de poblamiento en los pueblos indigenas, que casi siempre responden a modelos de dispersión relacionados con la proximidad de los campos de cultivo, hizo indispensable el análisis de la organización del espacio municipal. De este modo, las categorias de parentesco, las formas de acceso y posesión de la tierra y el sistema de rotación de los puestos civiles y religiosos, fueron elementos claves para la explicación de las caracteristicas de las "secciones" o "segmentos" de la comunidad indigena". (Favre, 1984; Mulhare, 1996).

En un trabajo publicado por primera vez en francés en 1971 y en castellano en 1973, Henri Favre se propuso explicar las caracteristicas de las subdivisiones de la comunidad indigena de los Altos de Chiapas, a través de una perspectiva que buscaba trascender los modelos funcionalistas y sincrónicos precedentes. Propone el concepto de "ciclo de desarrollo comunitario" concibiendo a la comunidad como la forma más elevada de la organización social en los Altos de Chiapas. Según Favre, en toda comunidad actúan fuerzas centripetas y fuerzas centrifugas, cuyo juego hace que se formen los parajes; éstos, con el paso del tiempo, llegan a convertirse en comunidades. Las acciones del exterior y el 
crecimiento demográfico determinan el ciclo de desarrollo comunitario; este ciclo implica un perpetuo proceso de destrucción y de reestructuración de la comunidad, cuyo ritmo y modalidades están determinados por el sistema colonial.

Para Favre, la comunidad se encuentra dividida en secciones, las cuales, además de ser subdivisiones territoriales, son unidades sociales cuya cohesión reposa en la endogamia y en el ejercicio de un fuerte control sobre sus posesiones: se cuida que sus campos no sean vendidos ni transferidos, se fijan las fechas de la siembra y de la cosecha, se controlan las aguas para irrigación y se vigilan las acciones de los individuos. Sin embargo, las secciones están implicadas en un sistema que las sobrepasa y que permite su complementariedad: la jerarquia politica y religiosa. Los cargos que esta jerarquia comporta se reparten anualmente entre cada una de éstas.

Favre explica que existe un proceso de erosión al interior de las secciones que tiende a debilitarlas, hasta el grado de hacerlas desaparecer por completo de la estructura comunitaria. En muchos casos, la seccion ha dejado de constituir un grupo localizado, como en Tenejapa, Chamula y Chenalhó, pero en otros se mantienen, como en Aguacatenango. Tambièn es posible la aparición de secciones en comunidades nuevas, o que retomen consistencia en lugares donde tendian a desaparecer (1984: 133-187).

Eva Hunt y June Nash escribieron en el Handbook of Middle American Indians (1975) acerca del paraje indigena en un articulo titulado "Local and Territorial Units". Afirmaron que éste no es una unidad territorial autónoma, sino una subdivision territorial con fronteras flexibles; sus funciones sociales son una adaptación a las demandas estructurales de la comunidad más amplia de la cual forman parte (p. 258). En este trabajo, las autoras expresaron nitidamente la orientación funcionalista de la antropologia británica, que había influido decisivamente en los antropólogos norteamericanos, especialmente en los estudiantes de la Universidad de Chicago bajo la influencia de Radcliffe Brown (Medina, 1991: 15).

Hunt y Nash consideran que el paraje es un segmento de la comunidad de manera similar a como el linaje segmentario forma parte de un linaje; los parajes funcionan a través de un principio de oposición segmentaria. Las autoras asignan al ciclo anual de fiestas la capacidad de reforzar el sentido de unidad para el municipio; aplicando la terminologia durkheimiana caracterizan al paraje como "un sistema de subdivisiones territoriales basado en la solidaridad mecánica" (p. 279). Las eventuales tendencias de fisión por parte de estas unidades territoriales, cuando tienden a separarse y a adquirir independencia en el estatus politico -como en los parajes de Zincantan-, pueden ser controladas mediante procedimientos asociados a la jerarquia civico-religiosa, por ejemplo incrementando del número de puestos, tanto del ayuntamiento como del sistema 
de cargos religiosos.

Evon Z. Vogt y el grupo de investigadores del Proyecto Harvard, caracterizaron a los parajes de los Altos de Chiapas como patrilinajes, familias patrilocales extensas o un conjunto de patrilinajes. Vogt señaló la existencia de un desplazamiento ceremonial muy estratégico entre estas agrupaciones residenciales que llama parajes o snaès, (el término sna significa en tzotzil "las casas de") para cumplir con los cargos de la jerarquía religiosa de Zinacantan. Manifestó su asombro al observar lo que èl consideró una "forma muy eficaz" de funcionamiento de dicho sistema de rotación de personal, cuyo fin es el de sostener una compleja vida ceremonial. Llama "movimientos ceremoniales ritmicos" a dichos desplazamientos, los cuales, en definitiva, ligan al centro con los parajes y con sus ramales. (1980: 79-80).

Pero ya Sol Tax habia señalado las caracteristicas de algunos de los municipios mayas de Guatemala, cuyos pueblos o cabeceras municipales no tienen residentes fijos, sino que se trata de "pueblos vacios", dado que la mayor parte de su población habita en terrenos distribuidos por el resto del territorio municipal. Los indigenas sólo acuden al pueblo en ocasión de gestiones administrativas como registros de nacimientos o defunciones, para el comercio de sus productos, para asistir a las festividades y para el cumplimiento de algún cargo de la jerarquia secular y religiosa. (1996: 98-111)

Aguirre Beltrán, desde Formas de Gobierno Indigena (1953), señalaba refiriéndose a los tzeltales y tzotziles:

"Teóricamente cada linaje ocupa un territorio particular, conocido con el nombre de paraje; en realidad, familias extensas pertenecientes a linajes distintos ocupan un mismo paraje, ya que en la primitiva organización consanguinea se van introduciendo alteraciones sustanciales y variables, que en ocasiones impiden un reconocimiento ... El encadenamiento de varios linajes, hoy parajes, da origen a un calpul o barrio. La vieja designación nahua del clan geográfico, calpulli, persiste entre tzeltales y tzotziles. La ligazón de los barrios o calpules en numero de dos -Oxchuc-, de tres -Chamula-, de cinco-Chalchihuitán-dan la forma total a la comunidad o municipio". (p. 122-23)

En cuanto a las gestiones del gobierno, Aguirre Beltrán señaló que las autoridades del municipio -los principales-son electos de entre los principales de cada linaje o paraje; éstos, a su vez, son escogidos de entre los jefes de las familias extensas. Los gobernantes habitan durante el lapso de su encargo en el centro ceremonial. Este se haya territorialmente dividido en tantas secciones como barrios o calpules haya en la comunidad y cuenta con un numero muy reducido de habitantes: sólo los gobernantes y sus familias, quienes se ven obligados a abandonar el paraje y sus campos de cultivo. Los puestos religiosos 
que ejercen los mayordomos son parte de las etapas sucesivas para acceder al rango de principal del paraje, del barrio y del conjunto de principales de la comunidad.

Nutini (1974) apuntó que en la mayoria de las comunidades del medio poblanotlaxcalteca existen "unidades intermedias" entre la comunidad global y los grupos domésticos o unidades de parentesco, las cuales tienen una importancia no solamente organizacional, sino también social y religiosa. Para este autor, el barrio es la más importante de estas unidades, y le atribuye una continuidad histórica que se remonta a la época prehispánica. El barrio en su contexto moderno puede encontrarse tanto como una agrupación con unidad simplemente territorial, hasta como clan exogámico patrilineal. Sin embargo, enfatiza que en esta área, el barrio exhibe un alto grado de integración sociorreligiosa y funciona de manera efectiva en la organización de la vida comunal (p. 345-346).

Nutini señaló la existencia de diez clanes patrilineales en San Bernardino Contla, cada uno de los cuales se dividia en varios linajes semilocalizados también patrilineales y exogámicos. Menciona, citando a Slade (1973) y a Murphy (1974), que en otros municipios -en Chignautla y Hueyapan-, los barrios o parajes constituyen los referentes residenciales de linajes exogámicos de poca profundidad (p. 343).

Danielle Dehouve (1976) encuentra entre los nahuas de Guerrero que "el linaje patrilineal (compuesto del padre y de sus hermanos y de los hijos de todos ellos) liga estrechamente su existencia a la del territorio: a las parcelas de cultivo común" (p. 62). Dehouve afirma que es el linaje el que da el derecho sobre la tierra y a formar parte de la comunidad; a cambio de este derecho los miembros del linaje deben participar en las tareas comunales y en la organizaciones de los cargos. Los linajes patrilineales son exógamos pero la comunidad en conjunto es endógama; las reglas matrimoniales establecen los lazos entre los grupos de residencia y los grupos territoriales. Encuentra también una organización dualista que se refleja en oposiciones a nivel lingüistico y geográfico. La división en mitades engendra una clasificación general para los habitantes de la comunidad, quienes intervienen en el cuadro comunitario a través del sistema de cargos e influyen en los grupos familiares a través de las reglas de matrimonio. (p. 57-73).

En un libro publicado en 1981, Huerta Ríos estableció existencia de clanes y linajes entre los triquis de Oaxaca. Huerta encontró que el linaje triqui no posee unidad territorial; sin embargo, el clan es una unidad territorial que constituye un grupo corporado. Un conjunto de familias extensas vive en contigüidad, formando segmentos de linaje, es decir grupos corporados de localización concreta. Los clanes están localizados en territorios que coinciden con las agencias municipales; cada población, con sus barrios y rancherias constituye 
un clan. La unión entre los miembros del clan se establece mediante el ejercicio de la endogamia (p. 117-148).

Según Bartolomé (1992), en Mesoamérica los conflictos territoriales intercomunitarios contribuyeron a afirmar las nuevas identidades en los pueblos indigenas. Las comunidades, al encontrarse en la necesidad de defender sus limites territoriales, estrecharon los vinculos con su espacio residencial y laboral. El modelo de aldeamiento en torno a la iglesia, implicó que las localidades que quedaban incluidas dentro del territorio municipal, reestructuraran sus relaciones con el nuevo entorno, especificamente cuando se trató de entidades socio-territoriales preexistentes que se unian a partir de su integración de una entidad politica (p. 259).

Se construyó de este modo un referente territorial que se sobrepuso a las adscripciones previas, pero que no siempre anuló las anteriores. La instauración del modelo de municipio implicó además el reconocimiento de un centro políticoadministrativo, proceso que supuso esta redimensionalización del espacio comunal. Bartolomé afirma que en Mesoamérica el efecto más dramático de esta imposición de un modelo de vida más congregado, fue la pérdida de una multitud de referentes simbólicos, los cuales estaban asociados a la posesión de un territorio a partir de la pertenencia a un linaje. Sin embargo, en muchas de estas localidades nacientes, el establecimiento de los centros politicoadministrativos, así como de capillas o parroquias, fue un vehículo para consolidar un nuevo referente de identidad común, permitiendo la continuidad de determinadas estructuras de organización, o bien reelaborándolas a partir de las condiciones actuales.

De esta forma se fue reconstituyendo una identidad local a partir del ámbito de la comunidad orientada hacia sí misma, es decir una identificación exclusiva con la comunidad de origen, lo que Bartolomé llama una identidad residencial. Desde mi punto de vista, se reconstruyó también una identidad más abarcativa, cuyo eje fue la instauración de las capillas y los santos patronos locales en las cabeceras municipales, proceso más tardio que el señalado por Bartolomé.

Tal y como se entendió al paraje como parte indisoluble de la dimensión comunitaria, activada como tal a partir del sistema de rotación de puestos en la jerarquia civica y religiosa, fue ineludible para distintos estudiosos, seguir la ruta trazada por Favre en el sentido de dirigir la mirada hacia las escisiones y evoluciones de los parajes $\mathrm{y}$, en consecuencia, de la estructura misma de la comunidad indigena. No obstante que el modelo de funcionamiento del municipio indígena tuvo amplias posibilidades de aplicación, fue evidente la existencia de una diversidad de procesos de transformación de las dinámicas territoriales en las comunidades. Estas transformaciones se relacionaban directamente con el funcionamiento de los sistemas de cargos y de rotación de puestos. Si bien en algunos casos cambiaba el centro de gravitación de los 
puestos religiosos, ello no siempre significó un decaimiento de la actividad religiosa.

Ya desde el trabajo de Cancian publicado en 1976, se percibe su preocupación por explicarse las tendencias en cuanto a la evolución del sistema de cargos en Zincantan, desde una perspectiva funcionalista. En este trabajo estableció que a medida que el crecimiento demográfico fuera compensado con la creación de nuevos cargos, continuarian las consecuencias integradoras del sistema en favor del equilibrio en la comunidad. De tal modo se canalizarian los excedentes producto de la creciente riqueza individual, amenaza para el equilibrio y la plena participación en el sistema de cargos. Sin embargo, Evon Vogt, en el "Prefacio" a la obra de Cancian, pronosticó que la comunidad sufriria escisiones que determinarian el desarrollo de sistemas de cargos adicionales, o bien que surgiria una élite que sostendria los cargos.

Varios lustros después, en 1990, Cancian publicó un artículo en el que revisa el sistema de cargos de Zinacantan: "The Zinacantan Cargo Waiting Lists as a Reflection of Social, Political, and Economic Changes, 1952 to 1987". (Stephen y Dow, coords.: 63-76). Señala que una serie de eventos han transformado la organización de la comunidad; destaca la presiones demográficas y económicas como las causas determinantes para la evidente disminucion en las listas de espera de los aspirantes a asumir los cargos religiosos. Este fenómeno se refleja, según Cancian, en dos áreas de la vida social de Zinacantan: en la diversidad ocupacional entre sus habitantes y en cambios en las relaciones entre los parajes y la cabecera municipal. Las demandas o presiones para invertir los excedentes económicos en vehículos u otros bienes y de contar con dinero en efectivo, han frenado la participación en el sistema de cargos. Ha aparecido, al final de la escala socioeconómica, un grupo de nuevos proletarios con menos recursos y seguridad económica.

Los parajes de Zinacantan incrementaron su densidad de población, fenómeno que propició el surgimiento de un nivel de administración independiente del centro. Con ello, los habitantes de la cabecera municipal han perdido el monopolio en el manejo exclusivo de determinados roles: la descentralización politica se incrementa notablemente en beneficio de la autoorganización en los parajes. La construcción de capillas en los caserios durante los años ochenta y el establecimiento de imágenes y cargos religiosos asociados a ellas, fueron eventos que colaboraron en el proceso de descentralización e independencia de los parajes. Los cambios politicos también han tenido influencia en el sistema de cargos religiosos, lo cual se refleja en la disminución de las listas de espera para asumir los puestos. Para Cancian, en sintesis, el sistema de cargos sufre una suerte de desplazamiento como la institución central y dominante de la estructura social de Zinacantan. Concluye que tanto sus predicciones, planteadas en su obra inicial, como las que hiciera Evon Z. Vogt en el "Prefacio" a la misma, han resultado ciertas. 
Hacia principios de los ochentas, Victoria Bricker, estudiosa también de los Altos de Chiapas, y quien fuera integrante del Proyecto Harvard en los años setenta, publicó en inglés un estudio etnohistórico acerca de las prácticas religiosas de los mayas. Desde una perspectiva diacrónica, explora la mitología y el ritual mayas, argumentando que muchas de estas prácticas tienen en realidad un origen posterior a la conquista.

En esta obra, publicada en castellano en 1989, Bricker se acerca también a lo que llama "acontecimientos contemporáneos de los Altos de Chiapas", refiriéndose a los eventos desarrollados desde finales de los años cincuenta hasta principios de los setenta. Se refiere a lo que considera el surgimiento notable de un etnocentrismo expresado a nivel del caserio, el cual se manifiesta en la construcción de capillas, oficinas administrativas y cárceles, en un esfuerzo por depender cada vez menos del Ayuntamiento y de las iglesias ubicadas en el centro ceremonial. En ese momento Bricker vislumbra aún como posibilidad la competencia de estas nuevas capillas y sus respectivos cultos a los santos con las iglesias del centro ceremonial, competencia que con el tiempo podria dar lugar a una pérdida de importancia del sistema de cargos como "la principal institución que ha permitido la integración de la vida religiosa de la comunidad". (p. 331).

Robert Wasserstrom (1989) observó este acontecimiento en Zincantan después de 1970: la aparición de capillas y la creación de nuevos cargos en ellas, ha llevado a instituir una forma de celebración basada en la cooperación entre todos los habitantes para disminuir la responsabilidad individual y el gasto excesivo. Es decir, se sustituyó el sistema jerárquico, basado en la escala de servicio obligatorio, por uno cooperativo en el que los responsables de sostener el culto a las imágenes de las capillas son los habitantes del conjunto de la unidad territorial, a través de la integración de comités y grupos voluntarios. Los cargos religiosos y las ceremonias de renovación de año ya no son capaces, según Wasserstrom, de resolver las nuevas divisiones sociales y los conflictos politicos (p. 273-274).

El interés en este aspecto, como señala Mulhare (1996), radica en el hecho de que este sistema de subdivisiones en Mesomérica cambia actualmente a pasos veloces, $y$ en algunas comunidades ha desaparecido por completo, o bien se ha reorganizado bajo nuevas reglas. Diferentes cualidades sociales sirven hoy de base para estas subdivisiones, inclusive los grupos de descendencia, pero también nuevas formas de estratificación o patrones de poblamiento que responden a presiones de carácter demográfico, económico o politico. Es por ello que existen serios obstáculos para realizar actualmente estudios comparativos de forma sistemática.

Desde mi punto de vista, estudiar los procesos actuales de reorganización de 
estas subdivisiones, es un aspecto clave para la comprensión de la naturaleza de las transformaciones que tienen lugar en las localidades indigenas. A través del estudio del funcionamiento del sistema de fiestas en Atlahuilco me propongo presentar en el Capitulo IV, el cuadro de las relaciones intersectoriales que se manifiestan a través de la rotación de los grupos domésticos como anfitriones de las fiestas del calendario ceremonial. 


\section{CAPITULO III}

\section{EL CALENDARIO FESTIVO. LIMITES Y CONTINUIDADES DEL TIEMPO RITUAL.}

En este capitulo me ocupo de presentar una reconstrucción del calendario festivo de Atlahuilco, a partir de mi observación etnográfica, con el fin de ofrecer un panorama general del ciclo anual. Me interesa destacar la importancia de cada una de las fiestas en su posición relativa en el interior del calendario anual, especialmente de las fiestas principales, que aqui llamo "fiestas de renovación del centro ceremonial", aludiendo a su capacidad de convocar periódicamente la asistencia a la cabecera municipal de los habitantes de las congregaciones, rancherias y parajes del ámbito municipal. Asi mismo, destaco la orientación de la secuencia ritual celebrada en la fiesta de Todos Santos, como una ceremonia de ratificación de los vinculos de parentesco ritual.

En el curso del capitulo $\mathrm{V}$ me referiré a otros aspectos del pensamiento religioso de los nahuas, especialmente los relacionados con el culto a la tierra, a los señores del Tlalokan y otras deidades que ocupan un lugar relevante en el sistema ritual más amplio. Estos aspectos dan cuenta de un conjunto de eventos rituales especificos más asociados a la salud y bienestar individuales, a la fertilidad agricola y a los acontecimientos relacionados con la vida y la muerte de las personas, mientras que la realización del calendario de fiestas religiosas tiene una dimensión esencialmente colectiva que relaciona, rige y clasifica determinados órdenes de la vida pública.

En opinión de Florescano (1997: 229-251), uno de los cambios ideológicos más importantes durante el proceso de colonización en Mesoamérica, fue la sustitución del antiguo calendario de las fiestas indigenas por las efemérides y festividades cristianas. Hacia mediados del siglo XVII el calendario ritual impuesto por los conquistadores predominaba en las poblaciones de la Nueva España. El calendario y las instituciones que lo ponían en práctica fueron evidencia del triunfo de la iglesia católica sobre los cultos idólatras, el cual se manifestó visualmente a través de las procesiones, cultos y devociones que proliferaron por pueblos y comunidades de todo el territorio colonizado.

Los santos patronos se convirtieron en el emblema de los pueblos recién congregados y en torno a sus festividades se crearon lazos de solidaridad y de identidad. Las apariciones de santos en distintos puntos de las poblaciones indigenas fueron una respuesta hacia las necesidades de autoidentificación y autoafirmación de las comunidades desarraigadas de sus antiguos territorios. Se construyeron asi solidaridades comunitarias centradas en los santos patronos, en la 
posesión corporativa de las tierras y en los lazos de sangre y de parentesco. Siempre que la estabilidad de los pueblos fue amenazada, las creencias y los simbolos religiosos obraron como articuladores y defensa de la comunidad. El calendario religioso católico se convirtió en un calendario de celebraciones que desembocó en la renovación periódica de los vinculos comunitarios (Florescano, op. cit.: 254).

Las solidaridades étnicas se fortalecieron apoyándose en la organización religiosa, las mayordomias, la devoción a los santos patronos y en los rituales asociados a la liturgia católica. Este proceso acentuó paulatinamente las diferencias entre los pueblos indios y las élites blancas, mestizas y criollas. En los pueblos de indios, la plaza central y el templo se constituyeron en el escenario donde se realizaban los cambios de autoridades, las ceremonias y procesiones religiosas y la fiesta del santo patrono, simbolo de la identidad local.

Las imágenes de los santos que fueron poblando los altares y nichos de las iglesias indias adquirieron revestimientos antropomorfos, impresión referencial de las relaciones humanas. Como hasta hoy, santos y virgenes se movilizaron continuamente dentro y fuera el templo, en torno a él y hacia distintos puntos del municipio. Pareciera, dice Gruzinski (1995: 133), que todo se hubiera desarrollado como si desde el origen, el proceso cultural de movilización y de sincretismo hubiera pasado directamente a través de la imagen y sus manipulaciones, antes que mediante los discursos y doctrinas.

Hoy en dia los pobladores de las distintas localidades de la serrania zongoliqueña identifican a los pueblos -o entidades municipales- con el nombre de sus santos patronos. La geografia religiosa y la distribución de los santos tutelares denota un sistema clasificatorio del territorio estrechamente ligado a procesos de diferenciación intrarregionales. En cada pueblo se han desarrollado particularidades en la organización ceremonial en torno a la festividad de su santo patrón y a las imágenes con que se cuenta en su templo y capillas. El santo tutelar se sitúa en el más elevado rango, por encima del dios cristiano; es el protector, el padre de todos los que habitan en el territorio que se encuentra bajo su tutela. Sin embargo todas las imágenes de santos que tienen una presencia fisica en el interior del templo y las capillas, requieren una celebración en la fecha correspondiente y de acuerdo a la jerarquia asignada por los pobladores.

Cada ciclo local se integra por un numero variable de fiestas, las cuales se celebran en las fechas del santoral católico asignadas a las imágenes de santos que se poseen. Se confiere eficacia a cada una de las imágenes asignándole un espacio, un tiempo y una práctica ritual dentro del calendario anual. Sin embargo, ninguna fiesta se celebra aisladamente, aunque asi sucede en apariencia, sino como parte de un ciclo que inicia y termina en repetición. Es decir, el calendario festivo es un medio para fragmentar el continuo temporal en segmentos a través 
de la creación de limites artificiales, como lo sugiere Leach (1978: 45). Estas fronteras imprimen una dimensión al tiempo en periodos significativos, mediante la agrupación de simbolos y secuencias ceremoniales.

Los nahuas, por lo tanto, dedican gran número de dias al año a la realización de los rituales relacionados con el ciclo de fiestas religiosas. El paisaje ceremonial incluye una sucesión de festividades que adquieren su más amplia significación -más que por si mismas- por su lugar en el seno del conjunto. Ello constituye una parte fundamental de su experiencia, en la medida en que se expresa a través de una serie episódica de intercambios simbólicos entre los hombres y las divinidades. Este modelo de autogestión regenera los principios básicos del universo social, puesto que da lugar a transacciones reciprocas y relaciones de contraprestaciones entre los habitantes del municipio.

La conmemoración a cada imagen del calendario da origen a un sistema de relaciones sociales; requiere una movilización minima necesaria para que pueda realizarse el protocolo prescrito para toda fiesta. En esta movilización que se denomina mayordomia o "compromiso", interviene un grupo de personas en torno a un mayordomo o mayordoma y su grupo doméstico, el cual funge como directamente responsable de organizar y preparar la fiesta. La ocupación del cargo por parte de cada responsable de una imagen durante un periodo anual, representa la constatación de la circularidad del tiempo social. El ritual de entrega del cargo a un nuevo responsable marca una transición, una forma de relevo de uno a otro miembro participante. Los responsables directos de celebrar a una imagen, participan en un circuito de intercambios que involucra a todos aquellos que en el ciclo actual han asumido un compromiso de esta naturaleza.

Este programa ritual comporta elaboradas fases y secuencias mediante las cuales se cumple la progresión de su acción, a través de la rotación de cargos. De este modo se actualiza cíclicamente la concepción acerca de las imágenes del santoral de los nahuas. Estas pueden ser consideradas "simbolos dominantes" desde la perspectiva de Turner:

"los grupos se movilizan en torno a ellos, celebran sus cultos ante ellos, realizan otras actividades simbólicas cerca de ellos $y$, con frecuencia, para organizar santuarios compuestos, les añaden otros objetos simbólicos. ... estos grupos de participantes representan ellos también importantes componentes del sistema social secular, componentes que pueden ser grupos corporativos, tales como familias o linajes, o meras categorias de personas que poseen caracteristicas similares...". (1989: 25)

Los cargos ceremoniales enfatizan las diferencias y en determinados momentos se desarrollan en espacios cerrados, circunscritos a 
categorias de personas definidas en función de roles establecidos. La delimitación de los espacios sociales a partir de las secuencias ceremoniales, permite observar la ritualidad festiva de los nahuas como un espejo de las relaciones de jerarquia, de poder, de prestigio y de filiación en la arena social. En otros ámbitos sin embargo, como detallaré más adelante, se manifiesta su capacidad para transmitir mensajes de un amplio alcance cultural.

Cada celebración o mayordomia, mantiene una secuencia que consiste en una sucesión lógica de representaciones; consta de un principio y un fin bien definidos que permiten un relevo sincronizado de cada uno de los cargos. De ahi que podamos afirmar que en Atlahuilco, cada ciclo anual se compone de ciclos múltiples, los cuales se integran en el conjunto de experiencias comunitarias expresando cadenas sintagmáticas. El ciclo ceremonial anual representa el eje horizontal, desde el cual se desprenden un número finito de secuencias rituales, encadenadas entre si siguiendo su propio ciclo repetitivo. Este tipo de ordenamiento permite elaborar una clasificación social que se sostiene a partir de la acción conjugada de dos dimensiones: la dimensión diacrónica que refleja las transformaciones en el tiempo, y la actualización sincrónica del sistema que se dirige hacia la reorganización conforme al modelo.

Los rituales asociados al calendario festivo son pues instrumento de las regularidades, reducen la ambigüedad debido a su calidad repetitiva, rica en signos visuales que transmiten información; en palabras de Leach: "Participamos en rituales para transmitimos a nosotros mismos mensajes colectivos" (op. cit.: 62). Su elaboración se dirige a garantizar la continuidad y la repetición de los eventos que ligan a los hombres con las potencias divinas. Se trata de un código de sentido que rige las conductas individuales y colectivas, y que tiene profundas implicaciones en el campo de las reciprocidades sociales y simbólicas. Además de actuar sobre las apariencias de estabilidad, la ritualidad festiva permite dar sentido al cambio y armar una suerte de resistencia según un código cultural que se modifica pero que aboga por la permanencia de valores, prácticas culturales y sociales constitutivas de la propia sociedad.

El calendario festivo de los nahuas -y su implementación- no es, sin embargo, un medio de mantener un orden inamovible; actúa como generador de un dinamismo que le permite adaptación y capacidad de manejar los acontecimientos. Es decir, no ignora la existencia de tiempos sociales múltiples, la presencia de diferencias sectoriales, pero matiza los efectos de la historia y sus desafios atribuyendo un valor elevado a la continuidad de la tradición, tal y como ocurre en lo que Balandier (1990) llama "sociedades de tradición", sometidas constantemente a la prueba de las grandes transformaciones.

De acuerdo con Galinier (op. cit: 31) los rituales representan una 
herramienta para descubrir los esquemas indigenas de representación del mundo e integrar acontecimientos espacio-temporales en un todo funcional. El ritual puede existir fuera de toda referencia a un mito y representa una estructura cuya desciframiento requiere distintos niveles de interpretación. Los rituales constituyen estimulos para las reflexiones especulativas en la medida en que "alimentan y exacerban las motivaciones de los actores ... a través de dramas culturales ..."

El calendario ceremonial de los nahuas produce entonces una estructura que ofrece la realización de un conjunto de acontecimientos, en episodios ordenados en una sucesión de fases. Esta gestión de las regularidades, expresa lo que López Austin ha considerado una de las caracteristicas más notables de la religión mesoamericana: la preocupación por el arribo del tiempo, una preocupación que da lugar a complejos sistemas calendáricos y rituales, puesto que la sustancia divina es enviada a la tierra en forma de tiempo: "mediante la fiesta se colabora con el dios que llega, armonizando la acción ritual con la acción pautada del dios" (1990: 214). La contingencia puede ser un castigo de los dioses, mientras que la regularidad es su beneficio. El ciclo ritual constituye la formalización de la creencia mitica, que sustenta la concepción de la irrupción de los dioses en el tiempo-espacio de los hombres (77). Se refuerza de este modo la conexión continua entre las divinidades, los hombres y su espacio vital, dando lugar a una narración visual que se recibe y actualiza de manera corporativa.

El calendario ceremonial de los nahuas supone un trabajo intelectual de clasificación del tiempo, representando una respuesta hacia la exigencia de un orden en el cosmos y en el devenir de la existencia humana. Conforma un sistema articulado que en palabras de LeviStrauss (1964) podria ser considerado como una forma de pensamiento mitico: da cuerpo a las estructuras por medio de acontecimientos; el cosmos y sus secuencias ligadas a una temporalidad pautada, son vividos y armonizados a través de la ejecución ritual y práctica de un calendario de eventos socialmente dramatizados.

\section{a) El ciclo ritual y el paso de las estaciones.}

En Atlahuilco, las fiestas acompañan el paso de las estaciones. Los hombres van y vienen al ritmo de ambas, de las estaciones y de las fiestas. El maíz se cosecha sólo una vez al año, con magros rendimientos $y$ en pulverizadas parcelas; se combina con distintos cultivos temporales que integran el complejo de la milpa indigena: el frijol, la calabaza, el chicharo y la haba. Productos todos destinados al autoconsumo pero que no alcanzan a abastecer las necesidades de las familias durante un año entero.

El bosque proporciona trabajo a los habitantes de las congregaciones y rancherias, y su explotación ha dado lugar a una estratificación socioeconómica creciente. Los más pobres se dedican a elaborar carbón 
de los troncos de encino, a veces como asalariados, a veces utilizando árboles propios. Otros son aserradores de ocotes y venden sus tablones aserrados manualmente. Los más prósperos son aquellos que se han adiestrado en la carpinteria y venden sus muebles de rústicos acabados en las ciudades de distintos puntos del país. Muchos más, emigran a las plantaciones de café y caña en las tierras bajas.

De ahi que la vida de los habitantes de Atlahuilco sea un continuo movimiento entre el adentro y el afuera. Durante largas temporadas el pueblo y las rancherias se encuentran semi-vacios. El movimiento hacia dentro se rige por las necesidades impuestas por los cultivos locales, pero también por la participación en los compromisos ceremoniales relacionados con el calendario festivo, y con las ceremonias del ciclo de vida individual. La presencia es casi obligada, además, durante las cinco festividades principales del ciclo anual: Año Nuevo, Semana Santa, Corpus Christi, Todos Santos y dia de San Martín, patrono de Atlahuilco.

Antes de la primavera se inician los preparativos para la siembra, en espera de que las primeras lluvias lleguen oportunamente, en el mes de mayo. Durante la Cuaresma y aún transcurridas las festividades de Semana Santa, los dias son de estiaje y calor. El paisaje de la Sierra es triste. Amplias extensiones que antes fueron bosques, lucen desbastadas por la roza y la quema. Las laderas humeantes evidencian la magnitud del esfuerzo humano que se requiere para rozar y cultivar empinadas cuestas, terrenos cuya delgada capa fértil es arrastrada en cada época de lluvias.

En esta temporada se sufre por la escasez de agua. Los breves manantiales y arroyos dispersos por cañadas y cerros desaparecen casi totalmente. Las mujeres lavan prendas de vestir y cobijas de lana a lo largo de un delgado hilo de agua que atraviesa el pueblo, serpenteando por patios y campos de cultivo. Este paisaje produce el efecto de hacer más notoria la pobreza. Para la mayoria de las familias casi se agotaron las reservas del maiz cosechado el año anterior -entre los meses de octubre y noviembre-. Los muros de las casas de madera que se acomodan en torno al camino y en las lomas que circundan el valle, lucen inclinados, algunos a punto de caerse. Algunas de estas viviendas se encuentran cerradas mientras sus poseedores trabajan en las plantaciones de la tierra caliente.

Una vez pasadas las labores de la siembra, en el mes de marzo, se inicia el éxodo hacia las tierras bajas donde espera el trabajo en las plantaciones de caña. Los hombres de las rancherias y congregaciones, quienes habitan en un entorno aún boscoso, han elaborado docenas de rústicas sillas y mesas de madera y emprenden el viaje hacia distintos destinos urbanos, allende las capitales del sureste, al altiplano central del pais, o hacia algunas ciudades veracruzanas. 
Aquellos que parten a las plantaciones de caña y café de las llanuras y montañas bajas de la franja central de Veracruz, se mueven con su grupo familiar, o con parte de él, dejando las viviendas cerradas y los animales y cultivos a cargo de sus parientes más próximos, pero los carpinteros-vendedores ambulantes parten sin sus conyuges y sin sus vástagos, en grupos de dos o tres, casi siempre miembros de una misma agrupación residencial. Todos ellos retornarán en ocasión de las fiestas de Semana Santa, trayendo provisiones y dinero para celebrarlas. Pero mientras tanto muchas casas están cerradas y los tendajones exhiben escasas mercancías, como a la espera de tiempos mejores.

En el verano el paisaje se trastoca visiblemente. El valle donde se asienta la cabecera municipal de Atlahuilco luce colmado de ondulantes milpas de un verde intenso. Las lluvias impregnan la tierra, las noches son frescas y luminosas. Muchas familias han regresado para realizar la segunda limpia a sus cultivos, trayendo algunas ganancias y provisiones. Sin embargo, es el otoño la temporada más próspera, cuando se realiza la cosecha del maiz y de los frutales que albergan algunos huertos domésticos: duraznos, ciruelas y manzanas. Se dispone pues de ciertos recursos para celebrar las fiestas que anuncian la llegada del invierno: las festividades de Todos Santos y del Santo Patrono en el mes de noviembre.

La gente de Atlahuilco se mueve pues entre el adentro, espacio ritual, festivo y de pertenencia, y el afuera. El calendario ritual se realiza a partir de una distribución de tareas destinada a garantizar su celebración en el seno de una sociedad que se mueve entre estas dos esferas, siguiendo un ritmo marcado por las fiestas y las labores de la milpa y las plantaciones. Las festividades posibilitan el continuo reforzamiento de los lazos sociales entre la población dispersa, y son su principal referente simbólico de unificación colectiva.

Cada grupo doméstico que se hace cargo de celebrar alguna de las fiestas, organiza sus periodos de trabajo fuera del pueblo con la suficiente anticipación para reunir los fondos necesarios para cumplir su compromiso, al mismo tiempo que se programa para permanecer dentro durante la temporada correspondiente. Una vez realizada la fiesta que se comprometió a celebrar, regresa a su lugar de trabajo, mientras que otro grupo doméstico se encuentra ya preparando la siguiente festividad marcada en el calendario. Muchos de ellos vendrán sin embargo, durante los dias que se conocen como las "fiestas grandes", mismas que pueden se consideradas como "fiestas de renovación del centro ceremonial".

La realización total de cada secuencia de mayordomia requiere de diecisiete días al año, siete en el protocolo de recibimiento del cargo y diez para el de la entrega del mismo. Por lo tanto, la celebración de las cuarenta y dos mayordomias en honor de las imágenes existentes en el 
templo principal de Atlahuilco, supone la realización simultánea de distintas fases de la secuencia ceremonial de cada una de las fiestas del calendario.

Se celebran, además, las fiestas relativas al ciclo de vida que dan lugar al establecimiento de vinculos de parentesco ritual: bautizos, confirmaciones, primeras comuniones, casamientos y funerales se suceden a lo largo del año, implementando relaciones de compadrazgo entre grupos domésticos de distintos puntos de la sierra (a diferencia de los cargos relacionados con el calendario festivo, restringido a los habitantes del municipio).

A lo largo del año se realizan dos bloques de actividad ritual intensa: del inicio de la Cuaresma, que coincide con el inicio del ciclo agrícola del maíz y con la llegada de la primavera, a las fiestas de Corpus Christi, cuya celebración se lleva a cabo en una fecha movible hacia mediados del mes de junio, cuando principia la temporada de lluvias y el maiz se encuentra a la mitad de su ciclo. De julio a octubre decrecen las festividades; los nahuas llaman a esta temporada como "época de la guayaba", debido a que es el periodo de mayor carestia de alimentos, temporada que antecede a la cosecha y cuando en un gran numero de hogares se han agotado las reservas de maiz.

El segundo bloque de actividad ritual intensa se inicia en el mes de noviembre, con las fiestas de Todos Santos y termina a principios de febrero, el dia de la Candelaria. Ello no implica, sin embargo, la interrupción total de un ciclo que debe sostenerse casi de forma permanente, como si se persiguiera permanecer en un tiempo sin rupturas, continuamente demarcado por los eventos que hacen visible la sacralización del tiempo y el espacio. El estallido de cohetes de pólvora, el paso de las imágenes y sus comitivas de un punto a otro del municipio, la música y la danza, son "símbolos estandarizados" (Leach, op. cit.: 21) que demarcan sonora y visualmente los momentos festivos, a manera de mensajes que confirman que se está contribuyendo a la recreación de las relaciones de los hombres con las potencias divinas. Estas deben fluir ininterrumpidamente, por ello, aún cuando decrece la actividad ritual en los periodos señalados, se celebran algunas fiestas menores, garantizándose así la continuidad del ciclo anual y evitando que se suspenda del todo el culto a los santos, matriz de la ritualidad festiva de los nahuas.

En ocasiones, por diversos motivos, no se consigue celebrar una fiesta en el dia preciso del onomástico de la imagen respectiva; se busca entonces la fecha más próxima a ésta. Sucede de igual modo con las fiestas relativas al ciclo de vida. En la primavera de 1998, recién celebradas las festividades de Semana Santa, observé asombrada la actividad ritual de un dia ordinario en la parroquia de Tequila. Antes del mediodía se celebró una misa de cuerpo presente, en la cual se oraba por el descanso del alma de un personaje destacado en la politica 
eminentemente inclusivo a nivel de todo el municipio, cuyos pobladores se asumen como "hijos de San Martin" (imagen residente en la iglesia de la cabecera municipal), los habitantes de parajes, rancherias y congregaciones de todo el municipio participan de manera activa en distintos periodos ceremoniales.

Las fiestas principales del ciclo corresponden hasta cierto punto con las asi consideradas por la liturgia católica, pero su celebración se encuentra condicionada a la existencia de la imagen respectiva, a su presencia fisica en el templo. Sin embargo, en algunos casos se ha asignado una imagen como respuesta al imperativo de realizar una celebración determinada, requisito de una orientación ritual que privilegia el culto a las imágenes. Por ejemplo, en las festividades del Año Nuevo se celebra una mayordomia en honor de un Santo Cristo, aun cuando no corresponde a lo señalado en el santoral católico; el objetivo evidente de este acontecimiento es la inauguración del ciclo ceremonial que inicia, y la sanción pública del compromiso asumido por los principales funcionarios involucrados en el mismo.

Una de las especificidades de las celebraciones religiosas de los nahuas, en contraste con las de otras regiones de México, radica en un contraste entre ritual cristiano y ritual indigena que equivale al contraste entre ritual celebrado dentro del templo y fuera de él (en el atrio y los alrededores del templo principal, y en el santohkalli de los hogares de los mayordomos). Es decir, un contraste que depende del espacio en el cual se celebra, tal y como lo sugiere Pitarch para los rituales tzeltales de Cancuc (op. cit.: 185).

Cada festividad requiere de una elaborada organización que se desarrolla en dos escenarios: en el espacio doméstico de los mayordomos entrante y saliente, y en el templo principal, el atrio y sus alrededores. En el perímetro del atrio y del entorno más próximo a la iglesia, se desarrolla la esfera pública y colectiva de la fiesta: las danzas, las procesiones, y la participación de los pobladores, más o menos moderada, dependiendo de la posición jerárquica de la festividad en el seno del conjunto del calendario anual. Las procesiones en torno a este circuito en ocasión de cada fiesta, parecen tener la finalidad de enmarcar ritualmente el espacio ceremonial. Como señala Vogt, los marcos consiguen enfocar la atención sobre los procedimientos rituales que se efectúan dentro de ellos (1979: 28).

La concurrencia a cada una de las fases de las fiestas, refleja las divisiones intrasectoriales de los habitantes del municipio. Mientras que, en términos generales, la población mestiza se hace presente en la esfera pública del ritual (la misa y las procesiones), el desarrollo ceremonial que se efectúa en los espacios domésticos de los mayordomos y el ofrecimiento de comida en el atrio, cuentan casi exclusivamente con la participación de los pobladores indigenas. 
El momento culminante de cada celebración ocurre cuando el mayordomo saliente participa en la misa de entrega de su cargo. Las llamadas "fiestas grandes", que representan la renovación de la cabecera municipal como centro ceremonial, pueden ser caracterizadas a partir de un patrón básico, exclusivo para estos rituales públicos. Abordaré en las próximas páginas dicha caracterización.

\section{b) Las fiestas de renovación del centro ceremonial.}

Johanna Broda (1969) apuntó que en el sistema calendárico de los mexicas, se celebraba una fiesta principal en cada mes de veinte dias, tal y como lo testimoniaron Sahagún y Durán. El carácter de estas ceremonias era sumamente complejo y su simbolismo reflejaba el elevado desarrollo cultural de Mesoamérica. En gran parte de estas ceremonias se invocaba a la fertilidad y a la lluvia, como corresponderia a una sociedad eminentemente agraria. Broda distingue tres tipos de fiestas dentro de cada ciclo: aquellas destinadas a las montañas, invocadoras de las lluvias; las dirigidas a los dioses de la fertilidad y las que se ofrendaban a las deidades individuales como Tezcatiploca, Huitzilopochtli o Yacatecuhtli (op. cit.: 24). El año consistia en una estructura de celebraciones o fiestas grandes a una distancia regular de veinte dias, pero en cuyo intermedio se llevaban a cabo fiestas preparatorias de menor importancia, las cuales no siempre estaban conectadas con las fiestas principales, pero se dirigian a objetivos especificos relacionados con la agricultura o con otras actividades cotidianas.

Hoy en dia, en Atlahuilco, las fiestas principales son algunas de las que marca el año cristiano, pero asignando a ellas una connotación que no corresponde del todo con la liturgia católica, aunque dentro del templo, el sacerdote intente apegarse a la realización de la misma. Estas celebraciones responden a la lógica impuesta por el sistema de cargos, ajustada al comportamiento de las fases y secuencias mediante las cuales se cumple la progresión del ciclo.

En este apartado me referiré a cuatro las celebraciones, mismas que desde mi punto de vista pueden ser catalogadas como "fiestas de renovación del centro ceremonial": la fiesta de Año Nuevo, el domingo de Pascua, la fiesta de Corpus Christi, y las fiestas de San Martin Obispo y San Martín Caballero (santos patronos del pueblo).

Desde el siglo XVI, las tres fiestas más importantes en los pueblos de indios eran las del santo titular, la de Corpus Christi y la de Semana Santa (Tanck de Estrada, 1997: 337). En Atlahuilco continúan teniendo preponderancia estas tres fiestas dentro el ciclo anual; se han agregado, además, la festividad de Año Nuevo y la de Todos Santos, dirigida a la memoria de los difuntos y a la ratificación de los vínculos de parentesco ritual. 
Si bien todas las fiestas del calendario ceremonial, expresan y validan los principios normativos y los referentes simbólicos de tiempo y espacio, en las "fiestas de renovación del centro ceremonial" se destaca el carácter público de un ciclo sostenido por la intervención de grupos de personas. Distribuidos en el entorno social, estos individuos efectuan los episodios y secuencias ceremoniales prescritas, y se presentan, al final de su gestión, en el espacio central de la cabecera municipal, el centro ceremonial. Durante la fase pública de estas festividades se observa a cada sector y grupo social ocupando su lugar en el seno del conjunto. Los pobladores de filiación cultural más cercana a la sociedad mestiza, manteniendo sus diferencias, se congregan con la población indigena proveniente de todos los puntos del municipio y participan conjuntamente en la misa y las procesiones aún cuando se encuentran ausentes, casi siempre, de los episodios rituales desarrollados en el interior de los hogares-.

No obstante que cada una de estas fiestas principales presenta sus peculiaridades, las cuales detallaré más adelante, señalaré a continuación los aspectos que las distinguen del resto de las celebraciones del calendario y que me han sugerido su caracterización como "fiestas de renovación del centro ceremonial".

Desde mi punto de vista, estas celebraciones tienen una doble connotación: su carácter de conjuntar a los habitantes de todo el municipio en un mismo espacio festivo, y la de ser marcadoras de tiempo, es decir, señalar momentos especificos que recuerdan la vinculación de la relación indisoluble entre el ciclo ceremonial y el ciclo de la agricultura y de la subsistencia. Mientras que el conjunto de las fiestas recuerda este último aspecto -la relación entre la vida, la subsistencia y las ofrendas rituales-, estas festividades implican un nivel de participación amplio y contienen una dimensión simbólica y estética distinta, que las convierte en referente común y conmemoración colectiva.

A diferencia del resto de las festividades, éstas constan de dos momentos culminantes: "las visperas", celebración que se lleva a efecto la noche anterior a la realización de la fase final de la fiesta, y "la entrega", que se realiza en el día del onomástico señalado en el calendario según el santoral católico, o que ha asignado por los pobladores en determinados casos. Es frecuente, sin embargo, que la celebración de las festividades se adecue a las posibilidades del sacerdote para efectuar la misa "de entrega", puesto que éste reside en Tequila, pueblo vecino, y se requiere de su presencia continua en los distintos poblados que corresponden a su jurisdicción parroquial. Durante "las visperas" se realiza una misa y fiesta nocturna en el centro ceremonial, el dia previo a la culminación, evento que recuerda que "iniciar el dia por la noche refleja muy bien la cosmogonía y el fin del mundo mesoamericano, reproduciéndose en la estructura temporal diaria la historia cósmica" (Segre, 1987: 158). 
En el día señalado para la conclusión de cada una de éstas, las principales celebraciones del calendario, el sol del mediodia acompaña el final de un ciclo y el comienzo de otro, el paso de la imagen de una a otras manos, su "entrega" a quien se hará responsable de ella durante el ciclo que empieza. En esta ceremonia se encadenan principio y fin, sin intervalo alguno de tiempo. Salen todas las "imágenes grandes" de la penumbra del templo y desfilan rodeando el atrio, cargadas en hombros, antecedidas por la banda de música, los danzantes, y el repique de las campanas; atrás de ellas, una muchedumbre de fieles canta alabanzas y portan flores y cirios encendidos.

Durante las fiestas comunes del calendario, la procesión después de la celebración litúrgica es también un procedimiento obligado, pero en ésta sólo se incluye a la imagen festejada y a las que fueron invitadas como sus acompanantes durante las secuencias ceremoniales llevadas a cabo en el espacio doméstico del mayordomo.

Después de esta procesión en la que desfilan todas las imágenes que en dias ordinarios resguardan las paredes del templo, otro episodio revela, como en una especie de narración no verbal, la estructura del sistema de organización que sostiene al ciclo de fiestas. Todos los mayordomos hacen acto de presencia en el atrio del templo principal y ofrecen ahi comida y bebida a su grupo de colaboradores de forma simultánea.

Ambos acontecimientos pueden ser vistos como un mensaje visual, una ceremonia comunicativa, en términos de Leach, dirigida a enfatizar la calidad repetitiva del calendario ceremonial y la responsabilidad eminentemente colectiva en su realización. Simboliza la unificación y cristalización de los esfuerzos individuales en la consecución de un mismo fin: la manutención del ciclo y el aseguramiento de la reproducción. En el pensamiento religioso de los antiguos mexicanos uno de los puntales de la idea del ciclo era la restitución, devolver a los dioses las fuerzas necesarias para producir lo recibido. (López Austin, 1994: 204).

La comida y bebida en el atrio, en cuarenta y dos circulos de comensales que equivalen al número de fiestas del calendario, puede ser interpretado como una metáfora del modelo de las relaciones entre el centro ceremonial y los parajes y rancherias del municipio. Una vez pasada la fiesta, el tiempo calendárico prosigue y los responsables de su continuidad preparan las respectivas secuencias y episodios rituales.

\section{La fiesta de Año Nuevo.}

El ciclo anual inicia con las festividades de Año Nuevo, el primer dia del año. En esta fiesta se asignan formalmente los cargos a los funcionarios que serán los responsables de sostener el ciclo ritual durante el periodo que comienza. La coincidencia entre el inicio del calendario ceremonial 
con el año solar, remite probablemente al establecimiento de las jerarquias locales durante el periodo colonial. Cada pueblo contaba con sus puestos de cabildo, mismos que se rotaban, mediante elección, por periodos de un año; los cargos eran jerárquicos, siendo los menores (topil y tekitlahto) de origen prehispánico Estas elecciones debian ser aprobadas por los sacerdotes y funcionarios españoles (Chance y Taylor, 1987: 12).

Chance y Taylor (op. cit.) proponen que hacia el siglo XVIII, existia un sistema de cargos basado en una burocracia politica que excluía a los funcionarios religiosos, es decir, que era exclusivamente civil; aunque existian también las cofradias religiosas y los individuos podian ocupar cargos en los dos tipos de organización, ello no dio lugar a la unificación de las jerarquias durante el periodo colonial. Dicha unificación, según estos autores, aconteció hasta el siglo XIX, después de la Independencia, como consecuencia del cambio del patronazgo colectivo al individual en las fiestas religiosas. En este periodo los pueblos tuvieron la libertad de reconstruir sus organizaciones religiosas y expresar sus creencias a través de los rituales.

El inicio pues, del año ritual en coincidencia con el calendario solar seguramente tiene sus antecedentes en el establecimiento anual del cabildo en los pueblos de indios durante la Colonia. Hoy en dia en los pueblos de la sierra de Zongolica, los funcionarios civiles sancionan el cambio de mayordomos y funcionarios religiosos durante la ceremonia de Año Nuevo. En esta ceremonia se manifiesta explicitamente que se espera de los mayordomos y sus funcionarios que se apeguen formalmente al guión establecido para conseguir la cobertura completa del ciclo. Los funcionarios encargados de sancionar el acto son el grupo de Sacristanes y el Presidente Eclesiástico. Este último se encarga de llevar el registro de los encargados de cada mayordomia, de autorizar los movimientos de las imágenes y "la ornamenta" o parafernalia ritual y en fin, de coordinar la celebración de todo el ciclo. El cuerpo de Sacristanes se integra por un grupo de doce Sacristanes Menores o Semaneros, encabezados por el Sacristán Mayor, también llamado Diputado Mayor. Corresponde a este funcionario financiar la misa y el banquete de la ceremonia de Año Nuevo.

El de Sacristán Mayor es un cargo de alto prestigio, mientras que el de Sacristán Menor o Semanero se considera como un servicio meritorio hacia el templo y los mayordomos. Estos doce funcionarios menores se turnan de forma rotativa, en parejas, para cuidar el templo dia y noche a lo largo de una semana, lo cual significa que a cada pareja le corresponden ocho o nueve semanas de servicio en un año. El Sacristán Mayor, antes de iniciar su gestión debe haber reunido a su grupo de Semaneros, generalmente jóvenes que aún no han asumido ningún otro cargo religioso. Ellos inician de este modo su participación en la vida ceremonial del pueblo; si proceden de alguna de las rancherias se trasladan a la cabecera municipal durante el tiempo que les 
corresponde (cuentan para ello con una habitación a un costado del templo).

El Sacristán Mayor se ocupa de funciones de alto rango: atender los asuntos de mayor importancia en relación al templo, como recibir y asistir al sacerdote, participar en los oficios religiosos al lado de los mayordomos en los dias de fiesta y coordinar al grupo de Semaneros. Estos últimos tienen como principal cometido el de señalar el fluir del tiempo diario, mediante acompasados repiques de campanas. Durante varios minutos anuncian diariamente la llegada de la aurora, el arribo del sol al cenit, el inicio de la tarde y por último, el comienzo de la noche; el repique puede ser prolongado, suave, ritmico, más o menos sonoro. No obstante, este ritmo acompasado que marca el paso del sol en su diario devenir, conoce las disrupciones obligadas por la desgracia de algún fallecimiento: a través de un código establecido se anuncia la edad, sexo y la solteria, viudez o condición de conyuge de quien acaba de abandonar este mundo.

Más que la celebración del año calendárico, en Atlahuilco la ceremonia de Año Nuevo se refiere explicitamente a la inauguración del año ritual. Dado que toda fiesta del ciclo debe seguir la estructura ceremonial básica, en este día se festeja a una imagen de Jesucristo que se conoce como "Santo Cristo del Sacristán Mayor", de modo que adquiera la estructura de una mayordomia, al mismo tiempo que se sanciona el compromiso recién adquirido por parte del grupo de mayordomos y sacristanes entrantes. Esta festividad se realiza de acuerdo al esquema de las fiestas de renovación del centro ceremonial.

La noche de fin de año, se llevan a cabo "las vísperas" de la fiesta del "Santo Cristo del Sacristán Mayor". Entre la neblina invernal, los danzantes y la música de banda ocupan el atrio de la iglesia, mientras dentro del templo se lleva a cabo la misa, en la cual los mayordomos y sacristanes reciben su cargo. Al salir, todos se reúnen en el atrio, cada nuevo mayordomo integra un circulo con sus colaboradores o teachkameh y les ofrece comida y bebida, antes de la quema del castillo de pólvora.

Llama la atención el hecho de que se asigne a un Cristo, imagen de un moribundo, una festividad que desde la perspectiva del catolicismo se encuentra vinculada a las celebraciones de la natividad de Jesús y al agradecimiento por los favores recibidos durante el año que finalizó. Pero la gente de Atlahuilco decide iniciar el año venerando la imagen de Jesús crucificado, advocación que será recordada en distintas ocasiones a lo largo del ciclo.

Se ha señalado que la cruz conserva, no obstante su asimilación como simbolo cristiano, una relación estrecha con la fertilidad agraria y la lluvia. El simbolismo cruciforme se vinculaba en tiempos prehispánicos a las direcciones cósmicas y arraigó en rituales agrarios manteniendo 
sus atributos de fertilidad y mantenimiento (Segre, 1987; Galinier, 1990; Báez Jorge, 1988 y 1998). El símbolo de la crucifixión fue incorporado poniendo énfasis en los detalles del sacrificio. Según Aguirre Beltrản, Telpochtli, el joven dios sol al momento de nacer por el rumbo del Este se funde con Jesús crucificado. La idea del martirio y la muerte seria una de las prédicas impulsadas por los evangelizadores franciscanos, la cual fue sincretizada con la idea mesoamericana de sacrificio (1986: 96). El culto a la imagen de Jesús crucificado, que recuerda el nacimiento del sol corresponde en Atlahuilco al inicio del ciclo anual.

Durante la fiesta de Año Nuevo, el Sacristán Mayor inaugura el lapso que empieza, ofreciendo los banquetes correspondientes en su espacio doméstico. Sus invitados principales son los doce Sacristanes Menores - Semaneros y el resto de los mayordomos que se harán cargo de sostener el calendario festivo en el transcurso del año. Es por ello uno de los puestos más onerosos y de mayor prestigio dentro del sistema de cargos religiosos.

\section{E1 Domingo de Pascua.}

Como decia páginas atrás, en Atlahuilco, el principio de la Cuaresma marca una fase de intensa actividad ritual. Durante la Semana Santa, se suceden una serie de episodios rituales encaminados a conmemorar la pasión y muerte de Cristo, ceremonial que coincide con los preparativos para iniciar el ciclo agricola del maiz. Indudablemente el conjunto de secuencias ceremoniales que tienen lugar durante la Semana Santa se inscriben dentro de la visión cíclica del tiempo y se relacionan con la regeneración de la naturaleza. La primavera, inicio de la floración y del reverdecimiento de los bosques es también el momento de sembrar la tierra y esperar que se cubra con el verde de las milpas. Para los nahuas, el follaje es el vestido de la tierra y predomina la idea de la restitución a través de la siembra, mediante la cual los campesinos regeneran la cubierta vegetal arrasada por la roza y la quema (Alvarez, 1991).

Las festividades de Semana Santa pueden ser interpretadas como la dramatización de la muerte y resurrección de Cristo, relacionada con la muerte y resurrección del sol y de la naturaleza. Este episodio culmina con el triunfo de la vida sobre la muerte, el renacimiento del Cristo-Sol, tal y como interpreta Segre la Semana Santa en San Miguel Tzinacapan (1987). La celebración del Domingo de Pascua simboliza la asociación permanente entre vida y muerte, y la idea del santo patrón como sustituto del dios protector omnipotente.

En cada episodio de la celebración de la Semana Santa se festeja a una imagen distinta, organizada en sus respectivas mayordomias. ${ }^{1}$ La

\footnotetext{
In el Apéndice se presenta una descripción completa del desarrolio de las fiestas de Semana Santa en Atlahuilco. 
representación de la pasión y muerte de Cristo se lleva a efecto mediante el movimiento de las imágenes en las esferas domésticas de cada mayordomo y en el templo y el atrio, el centro ceremonial. Los sermones de las homilias resultan mucho menos elocuentes que el despliegue público de cada advocación del dios cristiano; cada imagen es para los nahuas un interlocutor por si misma, con la cual se establece una transacción simbólica, al igual con el resto de las imágenes del templo. Cada una despliega sus propias potencialidades, por ello se le adjudica un nombre que la individualiza, que convierte en distintos "santos" a las representaciones del dios cristiano en su martirio: San Ramos, Padre Jesús Nazareno, Señor Calvario, Santo Entierro y Señor de la Resurrección. La antropomorfización de las divinidades organiza la interpretación y la trama de la festividad de Semana Santa.

La fiesta inicia el Domingo de Ramos, primer dia de la Semana Santa, con la veneración a San Ramos, imagen de Jesús montado en un asno, y la bendición de las palmas. En este dia Iglesia Católica conmemora la entrada de Jesús en Jerusalén, a su regreso del Monte de los Olivos. El jueves Santo es la imagen de Padre Jesús Nazareno la que acompañará a los Apóstoles en la representación de la Ultima Cena. Esta es financiada por un miembro de la comunidad, quien asume el cargo (como Tekitlahto) especificamente para preparar y llevar los alimentos que comerán los Apóstoles en este dia, sentados a la mesa con la imagen de Padre Jesús Nazareno.

El Viernes Santo son las imágenes de Señor Calvario y Santo Entierro las que recrean los pasajes de la crucifixión y muerte de Jesús. Si bien su intervención se combina según la iconografia y disposiciones difundidas por la Iglesia, las propiedades contenidas en ellas imprimen un sentido peculiar a la celebración. En la celebración del viernes Santo, la muerte es asumida como una experiencia colectiva que canaliza un estado de ánimo que permanecerá hasta el Domingo de Pascua.

La simulación de la Crucifixión y la muerte del dios cristiano, el Viernes Santo, se convierte en uno de los momentos más emotivos de toda la semana. Después del recorrido del Via Crucis, durante el cual algunos hombres se turnan para cargar una pesada cruz de madera, se introduce la procesión en el templo, así como la imagen del Santo Entierro, la cual descansa en un féretro con tapa de cristal. Participan en el desarrollo de esta secuencia una serie de personajes: los hombres que personifican a los trece Apóstoles (quienes han hecho penitencia desde el dia anterior permaneciendo en ayunas y en vigilia), cuatro niños vestidos con túnicas moradas que se llaman "jurios chicos", ocho hombres con túnicas negras y pelucas de paxtli, que se denominan "jurios grandes", la imagen de la Virgen Dolorosa, la imagen de la Virgen Verónica, la imagen de San Juan Apóstol y los mayordomos de cada uno de las imágenes mencionadas. 
Antes de que inicie la representación de la Crucifixion, la gente se acerca a adorar a la imagen del féretro con extrema devoción. Esta imagen permanece durante todo el año dentro de la capilla del Señor Calvario que se localiza a un costado de la iglesia principal, en dirección sureste. La figura será retirada de dentro del féretro para colocarla en la cruz, con los clavos que llevan los "jurios chicos", asi como una peluca y una corona de espinas, objetos que señalan su transformaciön en el Cristo crucificado. Después de la misa en que se celebra la Crucifixión se regresa la imagen al féretro, la cual será velada todo el dia y la noche como si fuera cualquier otro difunto, siendo venerada incluso hasta el Domingo de Pascua, una vez consumada la Resurreción de Jesús.

No obstante que el Domingo de Pascua se rinde culto a la imagen de La Resurrección que representa la vuelta a la vida del dios muerto, es hacia la imagen de Santo Entierro, a quien se vuelcan las oraciones, las ofrendas, las peticiones. Pareciera que el mensaje de la Resurrección no ha sido interiorizado, no obstante que el sacerdote en su prédica, consciente del pronunciado interés por el Cristo muerto, se esfuerza por hacer llegar un mensaje de gozo y alegria por el triunfo de la vida sobre la muerte. Para los pobladores de Atlahuilco es preciso dar continuidad a la fiesta de la resurrección pero en la forma de toda mayordomia, y la imagen de la Resurreción se manipula y moviliza como el resto de las que integran el panteón local. Terminando las festividades de la Semana Santa, el mayordomo que recibe a aquella imagen para el inicio de un nuevo ciclo, se dispone a continuar con los banquetes y convites en su santohkalli durante varios dias más.

Durante el Domingo de Pascua las imágenes de San Martin Caballero y Santo Entierro, aquel colocado a la entrada del templo y éste en el centro, frente al altar mayor, reciben a los fieles de todos los puntos del municipio. Ese día se llevan en procesión, en torno al circuito ceremonial establecido, todas las imágenes que se encuentran en el templo, encabezadas por el Señor de la Resurrección. Están presentes pobladores de todos los puntos del territorio municipal (es posible distinguir su lugar de procedencia por detalles de la indumentaria femenina), incluso quienes para ello debieron trasladarse desde las plantaciones de la tierra caliente, o desde las periferias de las ciudades donde venden sus mercancias y productos del bosque. Después de la procesión todos los mayordomos que intervienen en el sostenimiento del presente ciclo ceremonial, se acomodan en el espacio del atrio y convidan a sus colaboradores, sus teachkame $\boldsymbol{h}$, los tamales de frijol, el atole de maiz y copas de aguardiente que sus mujeres han traido en canastas desde sus cocinas. Después de este convivio en el atrio, se cerrará la jornada de esta fiesta de renovación del centro ceremonial.

Antes del atardecer, quienes han llegado de las rancherias y congregaciones, emprenden su camino de regreso. Es obligado despedirse de San Martín Caballero, jinete que permanece en la entrada 
del templo, y de Santo Entierro, difunto colocado frente al altar mayor. Ambas imágenes están rodeadas de veladoras encendidas y monedas. Ascendiendo por las veredas, algunos jóvenes, animados por el aguardiente, gritan de júbilo, otros hombres se quedan en el camino, demasiado embriagados como para continuar, mientras la cercania de la noche señala el final de este episodio en el centro ceremonial.

\section{La fiesta de Corpus Christi.}

En Atlahuilco, la fiesta de Corpus Christi es un referente temporal de la mitad del ciclo anual. La fiesta se celebra en una fecha movible, establecida por la Iglesia Católica con el objetivo de honrar la presencia de Cristo en la hostia. El calendario litúrgico estableció que la fiesta se celebrara el jueves siguiente al primer domingo de Pentecostés, que generalmente es en el mes de junio: Tanck de Estrada (op. cit.: 341344) señala que durante la colonia, en los pueblos de indios ésta era la segunda fiesta en importancia, en la cual la procesión era la actividad principal. En algunos lugares del centro de México se celebraba como una fiesta del final de la primavera, en la que las mujeres esparcian flores y adornaban con guirnaldas los altares. Se consumia gran cantidad de cera y pólvora para esta fiesta, uno de sus aspectos más caracteristicos. Viqueira (1997) señala también que durante el siglo XVIII la procesión religiosa de Corpus Christi era la más vistosa de todas, ya que aglutinaba a todos los creyentes, independientemente de su posición de casta o de clase social, aunque haciendo notar el orden jerárquico sobre el cual reposaba la sociedad colonial.

Hoy en dia, para los nahuas de Atlahuilco, esta fiesta continua ocupando un lugar relevante dentro de su calendario ritual, aunque por diversas razones carece del esplendor que la caracterizara en la urbe de la época novohispana. Durante esta temporada, los cultivos de maiz se encuentran a la mitad de su ciclo, y el ambiente ya ha sido refrescado por las primeras lluvias. El valle luce adornado por el verde de las milpas y en los solares domésticos florean las azucenas, rosas de castilla, gladiolas y margaritas que se cultivan en los jardines, especialmente para su uso ceremonial. En Zacamilola, poblado ubicado en una de los puntos más elevados del municipio, los árboles de ciruela y durazno se encuentran también en floración.

Testimonios de habitantes del pueblo recuerdan que esta fiesta, en algún tiempo, fue tomada como un augurio acerca de la intensidad de los temporales con que la época de lluvias afectaria los cultivos locales. Al final de la misa de celebración del Domingo de Corpus, el Sacristán Mayor dejaba volar dentro del templo a una paloma blanca, en una asociación metonimica con el icono religioso que representa al Espiritu Santo. Como mencioné en el capitulo anterior, se suponia que si el ave no buscaba la salida, se auguraba que las lluvias inundarian el valle, arrasando con las milpas; si abandonaba el recinto, era un presagio de que las lluvias serian benéficas, y moderada la creciente del arroyo que 
atraviesa la cabecera de Atlahuilco.

Se acostumbraba, por otra parte, realizar durante esta celebración, la ceremonia de cambio de Tekitlahtomeh, puesto asignado a quienes se encargaban de organizar el tequio, (trabajo colectivo obligatorio para todos los hombres adultos, mismo que se realizaba los lunes de cada semana o en casos de algún requerimiento especifico). Se nombraba a cuatro Tekitlahtomeh; uno de los cuales se denominaba Tekitlahto Mayor. Este se encargaba de anunciar el inicio de la jornada de trabajo colectivo, antes del amanecer, tañendo una flauta y un tambor desde la torre de la iglesia. Los Tekitlahtomeh Menores recorrian los rumbos del pueblo, conminando a los hombres a levantarse para iniciar la jornada.

El cargo de Tekitlahto duraba sólo medio año (el relevo se efectuaba precisamente durante la fiesta de Corpus Christi), y combinaba dicho tipo de obligaciones seculares con el servicio en la esfera religiosa. Aquellos designados para fungir durante la primera parte del año contraian además el compromiso de costear, preparar y servir la cena del Jueves Santo para los Apóstoles y Padre Jesús Nazareno. Quienes resultaban comprometidos para fungir en el cargo durante la segunda mitad del año, se hacian responsables de financiar y organizar la fiesta de Corpus Christi.

Actualmente, en Atlahuilco ésta fiesta es costeada por un mayordomo y solamente se nombra a un Tekitlahto cuya responsabilidad es servir la cena del Jueves Santo, compromiso contraido precisamente durante la festividad de Corpus Christi. El puesto de Tekitlahto se estableció dentro de las formas de gobierno colonial en muchos pueblos de indios y permanece en algunos de ellos, incluso en otros pueblos de la sierra de Zongolica, con atribuciones relativas a la difusión del trabajo comunal obligatorio.

Según Tanck de Estrada (ibid.) hacia finales del siglo XVIII, se resolvió en los reglamentos de los bienes de comunidad, disminuir las erogaciones en los pueblos de indios por concepto de las fiestas religiosas, ya que se consideraban excesivos, especialmente en las comidas y bebidas. Se estableció que en ningún pueblo de indios debian costearse otras celebraciones con fondos de las cajas de comunidad, más que las del santo patrono del pueblo y la fiesta de Corpus Christi.

En Atlahuilco, esta la festividad establece con claridad la mitad del ciclo agricola y la mitad del ciclo festivo. Considerada una de las "fiestas grandes", los pobladores de Atlahuilco han resuelto celebrar a dos versiones de la imagen: Santisimo Primero y Santisimo Segundo, tal y como ocurre con San Martin, para quien existe un San Martin Chico, y para San José, del cual existe tambièn un San José Primero y un San José Segundo. 
La jerarquización mayor/menor es común también entre los mayas, como sugiere Ruz (op. cit.: 403-405) y se corresponde con la importancia del criterio de edad en la organización social. La importancia de esta jerarquización aparentemente necesaria se observa en las imágenes duplicadas. ${ }^{2}$ Ante mis preguntas acerca de la razón de contar con dos versiones de una misma imagen, la respuesta ha sido que ello se debe a que se trata de imágenes muy solicitadas por los aspirantes a asumir el cargo de mayordomo; es necesario, por tal motivo, ofrecer más posibilidades, no obstante que se considera de mayor prestigio responsabilizarse de la imagen que lleva el apellido de Primero.

De modo que en esta festividad se celebra a las dos imágenes de Corpus Christi, sin embargo, de acuerdo con el principio de jerarquización, se considera la dedicada a Santisimo Primero, la fiesta principal. La de Santisimo Segundo se lleva a efecto unos dias antes, cediendole de este modo, el dia indicado para su celebración a la imagen de mayor jerarquia, pero llevando a efecto la misa de entrega del cargo, el mismo dia en que se celebran "las vísperas" del Santísimo Primero. La conclusión de cada una de las fiestas se realiza con sólo un día de diferencia.

La fase pública de la fiesta de Santísimo Primero se lleva a cabo durante dos dias consecutivos en el centro ceremonial. Un dia antes de la misa de entrega del cargo, tiene lugar la celebración de "las visperas", la cual, por desarrollarse al caer de la tarde, carece de la asistencia de las personas que viven fuera de la cabecera municipal. Sin embargo resulta vistosa y causa expectación por parte de los pobladores del centro y los parajes cercanos.

El dia de "las visperas", antes del amanecer, el mayordomo y su comitiva llevan en procesión a la imagen al templo para "hacer el alba". Desde varios dias antes, unas ocho imágenes distintas fueron llevadas por su mayordomo y una comitiva, para colocarlas en el santohkalli donde se encuentra la imagen festejada, con la finalidad de que "el santito no esté solo" y sea acompañado tanto en el altar doméstico como en los movimientos que realizará la imagen durante estos dos dias del final de su ciclo.

La procesión matutina se dirige al templo antecedida por una banda de aliento y un grupo de danzantes de la congregación de Atlehuaya. Las mujeres de los funcionarios llevan flores y copal para ofrecer a la imagen que permanece en el altar mayor del templo. Regresan después a continuar con los preparativos para el gran banquete de "las visperas" que será servido en la casa del mayordomo y al cual acuden un gran 
número de invitados: danzantes, músicos, mayordomos y comitivas de las imágenes invitadas como acompañantes, los tlatekimaitl (colaboradores especiales que cubren los gastos de los danzantes, de los músicos y de los juegos pirotécnicos) con sus respectivos círculos de teachkameh.

Todo el día se realizan pequeñas procesiones de un punto a otro: de la casa del mayordomo al templo para "hacer el alba", de la casa de los tlatekimaitl a la casa del mayordomo para la comida de la tarde, de ahi de nuevo al templo para la misa nocturna, y de vuelta a la casa del mayordomo para descansar hasta el dia siguiente.

La fiesta de "las vísperas" concluye con una misa al caer la tarde, precedida por la quema de fuegos artificiales y la actuación de los músicos y danzantes. Es la quema del castillo y el torito de pólvora uno de los eventos más esperados de la fiesta de Corpus Christi. La gente lo disfruta mientras los funcionarios custodian a la imagen el Santísimo Sacramento para que observe también las luces de bengala, un esfuerzo que significa una erogación económica considerable por parte del tlatekimaitl que adquirió este compromiso de colaborar con el mayordomo y proporcionar realce a la fiesta. Circula la cerveza y el alcohol; algunos duermen en la entrada del atrio mientras los danzantes continúan con sus monótonas evoluciones. Al final de la jornada, la música de banda encabeza de nuevo la procesión rumbo a la casa del mayordomo y los danzantes se dirigen a la casa del tlatekimaitl que costea su participación para pasar ahí la noche.

Al dia siguiente concluye la fiesta, con la misa solemne en la que el mayordomo entrega el cargo a su sucesor. Es entonces cuando aparecen caminantes desde distintos rumbos del municipio. Vienen con un esmerado atuendo. Las mujeres llevan blusas nuevas de satín, adornadas con encaje, lios negros y limpios sostenidos por fajas de colores brillantes, el cabello alisado con aceite y adornado con pasadores. Muy temprano los cohetes despiertan a los vecinos del centro del pueblo. A media mañana, los mayordomos de las imágenes que acompañarán a Santísimo Primero en la procesión rumbo a la iglesia, se presentan por última vez en la casa del mayordomo, donde se les sirve un desayuno. Mientras ésto ocurre, afuera de la casa bailan "los moros" de Atlehuaya y toca la banda de viento procedente de Tequila.

Se aproximan al templo algunas niñas vestidas con lío negro y blusa de encaje, cubriéndose la cabeza con un velo blanco y adornadas sus trenzas con listones blancos, ya que durante la misa recibirán el sacramento de la Primera Comunión. El recinto se encuentra repleto cuando la procesión del Santísimo Primero se encamina hacia ella. Los moros aparecen saltando sobre el fondo verde de las milpas, viene luego la banda de música y atrás un grupo de mujeres llevando ramos de flores, antecedidas por la Cruz Alta, el palio, y la imagen de Santisimo 
Primero en manos del mayordomo. Después, las imágenes acompañantes y sus comitivas.

El momento es altamente emotivo cuando estos funcionarios y las imágenes se introducen en el templo: repican las campanas, cesa la música de banda, estallan cohetes, un coro de voces juveniles acompaña la entrada, y el aroma del incienso, las flores, las velas, los alientos y humores de cientos de personas se confunden en un mismo ámbito profundamente sacro. Mucha gente canta las alabanzas que entona el coro, mientras se colocan en el altar principal a la imagen festejada y a sus acompañantes para que escuchen también los cantos y la misa. Al terminar ésta, se realiza otra procesión en torno al templo, en sentido inverso a las manecillas del reloj en la cual se integran ya muchos de los asistentes, asi como todas las imágenes grandes que resguarda el templo, en hombros de sus mayordomos.

Afuera, en el atrio, algunas mujeres esperan sentadas en el suelo, pacientemente, a que concluya la procesión para ofrecer los alimentos que guardan en sus canastas. Los ofrecerán a los teachkameh que colaboraron para ésta y otras fiestas del calendario. Al caer la tarde, la gente se dispersa en distintas direcciones mientras el mayordomo entrante, que a partir de hoy es el responsable de Santísimo Primero, inicia la secuencia de la fase de recibimiento, misma que se realizará durante siete dias en el seno de su hogar.

\section{La fiesta de San Martin.}

Los habitantes de Atlahuilco se consideran bajo la protección de San Martin, su santo patrono. Este se encuentra representado en dos advocaciones: San Martin Caballero y San Martin Obispo. Se dice que la imagen de la primera de ellas llegó procedente de tierras lejanas y decidió establecerse en el pueblo, a pesar de que los anteriores dueños de la imagen deseaban recuperarla; se volvió tan pesada que hubieron de dejarla en el sitio donde se construyó posteriormente la iglesia. Tal y como señala Ruz para los pueblos mayas, (op. cit.: 383) la idea de peregrinar en busca del mejor sitio para quedarse y dar origen a la fundación de un pueblo, es una constante en la sierra de Zongolica. Ello convierte al santo patrón en un héroe cultural y proporciona una identificación especial entre él y los habitantes del entorno fisico bajo su protección. La imagen de San Martín Obispo se adquirió después, pero no obstante que se asume también como el Santo Patrono del pueblo, es evidente que existe una notable predilección por la figura de San Martin Caballero. Es ésta la que se venera con mayor devoción y la que preside la entrada del templo durante las fiestas de renovación del centro ceremonial.

Sin embargo, cuándo se inquiere acerca de cuál de las dos imágenes es más importante, la respuesta es que ambos "mandan por igual", pero San Martin Caballero es quien asume la representación de ambas 
imágenes durante las procesiones y recibe las plegarias de quienes llegan desde distintos puntos de la región para participar en las fiestas importantes o para solicitar algún favor especial. Tal pareciera que esta figura se adecua a la disposición escenográfica de recibimiento: la figura alegórica de San Martin montado a caballo. Su ubicación en la entrada del templo, equivale simbólicamente a su ubicación en la entrada del territorio bajo su protección. A San Martin Caballero se le festeja dos veces al año: en las fiestas patronales de noviembre, y el 13 de abril, en honor de San Martín Chico, denominado de este modo aludiendo, por supuesto, a sus dimensiones, lo cual se refleja en la importancia, tambièn menor, de su fiesta.

En congruencia con la concepción de las imágenes como entidades per $\boldsymbol{s e}$, y con atribuciones propias, los nahuas consideran que es necesario realizar una fiesta para cada una de las representaciones de San Martín. Por ello, se ha establecido que la fiesta patronal -la fase realizada en la esfera pública y central de la cabecera- se lleva a cabo durante los dias 11 y 12 de noviembre. En esta temporada ya se ha realizado la cosecha de maiz y la llegada del otoño ha refrescado el ambiente, humedeciendo de neblina las tardes y las noches. La gente que fue a las plantaciones regresa desde fines de octubre para levantar la cosecha y estar presente en esta fiesta y en la de Todos Santos que se celebra diez dias antes.

A partir del dia diez de noviembre aparecen en la escena pública -el templo, el atrio y sus alrededores- el mayordomo de San Martin Obispo y su comitiva para celebrar "las visperas". Por la mañana, niños y niñas de las rancherias llegan a la iglesia arreglados con ropas blancas y guirnaldas de margaritas en el cuello y en la cabeza, para recibir después de la misa, el sacramento de la Confirmación. En el atrio, los moros de Atlehuaya se esmeran en su sencilla pero agobiante coreografia acompañados por los acordes de una banda de viento. Aún no es notable la afluencia de gente. Por la noche se llevan a efecto "las visperas" para San Martín Obispo con la celebración de otra misa; se quema entonces un torito de pólvora mientras en la entrada del templo se encuentra San Martin Caballero, emblema de Atlahuilco.

Paralelamente a la ritualidad festiva en torno al santo patrón, se desarrolla una vertiente de la fiesta en manos del sector mestizo del pueblo, de factura reciente, en la que se intenta dar un cariz de "feria" a las fiestas patronales. Esta modalidad les posibilita la obtención de cierto provecho económico, improvisando establecimientos para la venta de cerveza, refrescos y comida; se organizan además eventos civicos como un torneo de fútbol de alcance microregional y una competencia para elegir a una reina, escogida entre una terna de jóvenes de este mismo sector de población. No falta el baile de coronación de la reina de la feria, amenizado por conjuntos musicales de cierta fama en la región.

El dia once se dedica la fiesta a San Martin Obispo. Desde la 
madrugada se moviliza el mayordomo y su comitiva para llevar "las mañanitas" a la imagen en el dia de su santo. Se nota ahora mayor movimiento; aunque llega gente procedente de las rancherias y congregaciones, se dice que el día más concurrido será el siguiente, cuando concluye toda la celebración con la misa dedicada a San Martin Caballero, para quien hoy se celebran "las visperas".

El día del Santo Obispo, se puebla de nuevo el atrio con las mujeres de los mayordomos con sus canastas llenas de tamales y atole, ya que después de la misa, a mediodía, ofrecerán estos alimentos a los teachkameh de su respectiva mayordomia. Se aprecia la ausencia de la gente de Acultzinapa y Atlehuaya, las congregaciones más alejadas de la cabecera, quienes se reservan su asistencia para el día siguiente. Se aprecia también que no han acudido personajes destacados dentro de la vida ritual del pueblo; ello se debe a que han sido invitados a la casa del mayordomo saliente de San Martin Caballero, donde se realiza la fase culminante del ceremonial relativo a la esfera doméstica. Distintos banquetes están siendo ofrecidos en este dia de las "vísperas" de San Martin Caballero y del "mero dia" de San Martín Obispo, entre los mayordomos entrantes y salientes de ambos santos.

El dia doce de noviembre se realiza la fase final de la fiesta de San Martin Caballero. Es evidente el mayor esplendor, la asistencia de la gente de todos los puntos del territorio municipal, y el prestigio adquirido por el mayordomo que se comprometió a llevarla a cabo. La procesión con todas las imágenes, encabezadas por San Martín Caballero y la secuencia de los comensales en el atrio, son eventos que proporcionan en este dia la más clara connotación de fiesta de renovación del centro ceremonial.

Como en tiempos de la colonia, el atrio de la iglesia continúa siendo el área pública por excelencia, el ámbito donde confluyen la tradición india y la tradición católica occidental. La Capilla del Calvario construcción modesta donde se alberga a la imagen de Santo Entierro, a la cruz de madera que se utiliza durante el Via-Crucis y toda la parafernalia de la celebración de la Semana Santa-, se constituye también en un escenario recreado durante las fiestas de renovación del centro ceremonial. En este pequeño recinto se alojan los funcionarios religiosos y sus familias, quienes procedentes de alguna de las localidades de la montaña, requieren permanecer una o más noches en el centro del pueblo por motivos de su participación en la fiesta. Después de la misa San Martín Caballero se entrega la imagen al nuevo mayordomo y se realiza la comida en el atrio, donde los mayordomos que sostienen el presente ciclo, invitan alimentos y bebida a sus respectivos círculos de teachkameh.

Durante las fiestas de renovación del centro ceremonial, el tejido híbrido de las prácticas y creencias en relación a las imágenes de los santos más importantes para los nahuas, sostiene una solidaridad 
entre personas de distintas procedencias. La devoción a los santos se convirtió en un imaginario que

"entroncándose en la imagen polariza la atención anima deseos y esperanzas, informa y canaliza las expectativas, organiza las interpretaciones y las tramas de la creencia" (Gruzinski, 1995: 189-190)

En estas fiestas, se manifiestan relaciones y lazos que hacen compatibles los elementos heterogéneos del cuerpo social y configuran la existencia a través de estas puestas en escena, de las danzas y la música, de las procesiones y los banquetes.

\section{c) La fiesta de Todos Santos, reafirmación de los vinculos de parentesco ritual.}

Tal y como sucede para el mundo católico en general, para los nahuas, la fiesta de Todos Santos es una de las más relevantes del calendario. Se lleva a cabo durante los primeros dias de noviembre, cuando los pueblos de la parte alta de la sierra de Zongolica han iniciado la cosecha de maiz. Según Nutini (1988) los origenes de esta celebración se remontan al siglo XIV y en el mundo cristiano sigue en importancia a la natividad y a la Semana Santa. Se conmemora a quienes han logrado el estatus de "santidad"; en la segunda mitad del siglo XI se oficializó el dia primero de noviembre en sentido moderno de la festividad y adquirió desde entonces importancia en el ciclo anual en el sur de Europa y especialmente en España. Se conmemora a "los muertos en la fe", celebración que en su origen se destinaba a la oración por las almas del purgatorio. Según Nutini, esta fecha es el más claro ejemplo de sincretismo ritual, ceremonial y simbólico donde el cristianismo confluye con el monoteismo hebreo y el politeismo romano. De ahi que hasta bien entrada la Edad Media, la Iglesia estuvo renuente a establecer una liturgia especifica para este dia con la finalidad de disociarla de los ritos pre-cristianos y de las ceremonias de culto a la muerte de las distintas vertientes del politeismo indoeuropeo.

La práctica de celebrar el dos de noviembre se diseminó en Occidente hacia el siglo XII, y para el siglo XV el primero y dos de noviembre se celebraban como una unidad (ibid.). En el siglo XVI las dos fechas se habian combinado en el dia de Todos Santos y esa forma se introdujo en la Nueva España por los frailes. Dado que en las religiones prehispánicas existía el culto a la muerte, durante el proceso de evangelización se realizaron equivalentes simbólicos con el culto católico. Estos elementos sincréticos y funcionales del culto a la muerte se centraron en las festividades de Todos Santos. El papel de los muertos como intermediarios entre los dioses y los hombres se asignó a los santos del panteón católico, y con ello esta festividad se integró con el complejo del culto a la muerte durante la primera parte del periodo colonial, dando lugar a la celebración sincrética de Todos Santos. 
En suma, la celebración de Todos Santos y la honra de los difuntos se consolidaron en México como una misma festividad. Aunque de una a otra región varía actualmente la forma de rendir culto a los muertos, en términos generales el culto público de la muerte se estableció como una manifestación del catolicismo; el contenido del ritual y del ceremonial adquirió un lugar predominante en el ciclo católico. Se generalizaron las ofrendas colocadas en las tumbas de los muertos y en los altares domésticos en las regiones de tradición indígena.

La Iglesia católica distingue entre la festividad de Todos los Santos establecida el día primero y la de Todos los Fieles Difuntos, el día dos. En la primera de ellas, la Iglesia conmemora a todos los santos de Dios en un ritual propiciatorio para celebrar la gloria de Dios en compañia de aquellos mártires que se acercaron a la perfección a través de sus actos de glorificación hacia la divinidad. En la fiesta de Todos los Fieles Difuntos se ora por el descanso eterno de quienes han muerto en la fe, implorando por la salvación de su alma y en memorial de la muerte y la resurreción de Cristo.

En Mesoamérica, el culto a la muerte estaba presente a lo largo del ciclo ceremonial regulado por el complejo sistema calendárico. Según las crónicas, el calendario ceremonial y ritual de los pueblos nahuas del centro de México, incluía distintos momentos para rendir culto a los muertos. Se les recordaba en fechas establecidas en función de las circunstancias por las cuales los individuos fallecian; las causas de muerte definian su lugar al lado de los dioses y su destino final. Los guerreros muertos en batalla, por ejemplo, permanecian al lado de Huitzilopochtli, mientras que los muertos por condiciones relacionadas con el agua moraban en el Tlalokan, al lado de Tlalok; las siwateteo, mujeres muertas en el parto, viajaban al lado del sol en su continuo devenir por el universo.

En el noveno mes del año, Tlaxochimaco, se celebraba la fiesta pequeña de los muertos, Miccailhuitontli, dedicada a lo niños muertos, con cantos, bailes ofrendas y penitencias, preludio de la celebración dedicada a los difuntos adultos. El décimo mes, Xocotlhuetzi, se celebraba la fiesta grande de los muertos con mayor esplendor y solemnidad, en la que se consumian grandes cantidades de comida y pulque y se sacrificaban hombres en medio de espléndidas danzas y ceremonias. (Durán, 1965: 288-292). Nutini encuentra que en comunidades aledañas al volcán La Malinche, en el estado de Tlaxcala, se celebra una festividad que considera equivalente a la celebración prehispánica de Xocotlhuetzi, puesto que se celebra en las mismas fechas y con un desarrollo similar en determinadas secuencias.

Si bien, aparentemente estas fueron las fechas establecidas dedicadas a los muertos, en el transcurso de la cuenta de los dias, se recordaba a aquellos que habian trascendido hacia el inframundo por motivos 
especificos. Las siwateteo descendian cinco veces en el año ritual, debiendo los vivos protegerse de encontrarse con ellas en los cruces de los caminos, puesto que provocaban enfermedades y perjuicios. (Duverger, 1983: 30). En el mes Tepeithuitl, cuando se honraba a los montes, según Sahagún, se recordaba también a quienes habian fallecido ahogados. Durante el mes Quecholli, que era la fiesta en la que se ofrendaba a Camaxtli o Mixcoatl, dios de la caza, pidiéndole buena fortuna en la caceria; según este cronista se colocaban también ofrendas de alimentos en los sepulcros de los muertos (Sahagún, 1988: 81-98).

El culto a la muerte en Mesoamerica, tenía pues un papel central en la cosmologia y el ciclo anual de ritos y ceremonias, y encontró su equivalente simbólico en el culto católico introducido en la Nueva España por los evangelizadores.

Hoy en día, para los nahuas -como en el resto de México-, la fiesta de Todos Santos es la celebración a los difuntos; inicia el día treinta de octubre, con el recibimiento a las ánimas de los niños que murieron sin ser bautizados, y finaliza el dos de noviembre, cuando se despide a las almas de quienes fallecieron siendo ya adultos. El dia treinta y uno llegan las ánimas de los niños que murieron estando bautizados y de los jóvenes aún solteros. Se preparan alimentos especiales para cada una de estas categorias de visitantes, sin embargo para los primeros en llegar -las ánimas de los pequeños fallecidos sin bautizar- únicamente se colocan velas en el altar, puesto que se asume que aún no estaban en edad de consumir alimentos. Para esperar a quienes fallecieron siendo niños o jóvenes solteros se colocan ofrendas de frutas, pan, chocolate, atole, calabaza y elotes, evitando los licores y los alimentos picantes. El dia primero de noviembre llegan las almas de quienes fallecieron siendo ya ancianos o adultos casados, a quienes se les ofrendan tamales, un guisado a base de carne de res, aguardiente, cerveza y tabaco.

Las velas, el copal y las flores de sempoalsochitl son elementos imprescindibles en el altar doméstico, asi como en las tumbas de los familiares fallecidos cuyos restos se localizan en el cementerio municipal. De no llevarse a cabo este recibimiento, las almas de los muertos sufren una decepción al volver a casa y encontrar el santohkalli vacio, sin alimentos, sin ceras y sin humo de copal. Dado que se consideran intermediarias entre los humanos y el poder divino, en respuesta al olvido por parte de los familiares vivos, pueden propiciar desgracias, castigos o sufrimientos. Se cuenta de un hombre de Zacamilola, quien recientemente renegó de esta tradición y a los pocos dias sufrió un accidente fatal al trasladarse en caballo hacia su lugar de trabajo.

Se cree que las almas de los difuntos se alimentan de la esencia de los alimentos que se les ofrecen en el altar del santohkalli. Se despiden el 
dia dos de noviembre, cuando se levantan las ofrendas y se ingieren los alimentos, los cuales han perdido parte de sus cualidades $y$ propiedades: no tienen sabor ni son nutritivas para el organismo puesto que las ánimas han aprehendido su esencia.

Los tamales, el pan y el chocolate se disponen en la cantidad suficiente -o hasta donde permite la economia doméstica- para recibir la visita de los compadres pasado el mediodia del dos de noviembre. Se realiza entonces un intercambio de dones que permite interpretar esta fase de la festividad de Todos Santos como una "ceremonia de ratificación de los vinculos de parentesco ritual"3.

En esta ocasión se hacen explícitos de manera simultánea en un nivel colectivo, los lazos de parentesco ritual y la posición estructural de cada individuo con relación a sus parientes rituales. ${ }^{4}$ Los ahijados visitan a sus padrinos llevándoles pan y chocolate, obsequio ceremonial que debe ser entregado en un morral nuevo. Los padrinos les invitan a su vez a tomar chocolate y pan, probablemente del que recibieron de otros visitantes; al mismo tiempo les obsequian alguna prenda de ropa nueva, obsequio que legitima y ratifica la relación jerárquica existente entre el ahijado y sus padrinos. Puesto que esta reciprocidad implica dones diferentes en especie, expresa una desigualdad de estatus. (Leach, op. cit.: 9)

Las personas que tienen muchos ahijados se preparan con anticipación adquiriendo los regalos necesarios (especificamente prendas de ropa) para todos ellos, y recibirán a su vez cantidades considerables de pan y chocolate que les servirán para ofrecerlos a los visitantes y para llevarlos como obsequio al visitar a sus propios padrinos. Esta fecha, por tanto, da lugar a un circuito de intercambios en el que los individuos reciben o/y obsequian ropa y pan y chocolate, de acuerdo a sus distintas posiciones dentro de la red de vinculos de compadrazgo.

Todo participante en esta ceremonia lo hace desde su particular ángulo de visión, desde su propia perspectiva estructural. Los objetos que se donan y los que se reciben hacen explicita la diferencia entre donante y donatario. A través de esta ceremonia se ratifican las posiciones estructurales de los individuos dentro de las redes de parentesco ritual, lo cual constituye, al mismo tiempo, una afirmación de las relaciones de carácter interpersonal. Como señala Godelier (1998: 26-27) el don

\footnotetext{
Utilizo el término "ceremonia" de acuerdo a la concepción sugerida por Víctor Turner, según la cual, tiene un sentido más ajustado a aquelias conductas religiosas asociadas a estados sociales, y en las que las instituciones politico legales tienen mayor importancia. El término "rito" se aplica a formas de conducta religiosa que se hallan asociadas a transiciones sociales, mientras que el ritual es transformatorio, la ceremonia es confirmatoria. (Turner, 1980, 105).

4 Sandstrom (1991, 282) menciona una tradición similar entre los nahuas de la Huasteca Veracruzana, quienes también en ocasión de estas fechas, obsequian comida -especialmente tamales- a sus parientes rituales. 
encuentra las condiciones de su ejercicio en el seno de sociedades cuyo funcionamiento se funda en el mantenimiento de este tipo de relaciones. Se haya presente en los dominios de la vida social en los que las relaciones personales desempeñan un papel dominante.

Esta circulación de dones pone en evidencia la desigualdad existente entre las personas que son frecuentemente solicitadas para una relación de compadrazgo, es decir, que tienen muchos ahijados, y aquellas otras que son más bien solicitantes. Las primeras adquieren un mayor número de compromisos y obligaciones morales, económicas y sociales, situación por la cual se requiere contar con una relativa solvencia económica poco frecuente entre los grupos domésticos de los pueblos y localidades de la región. Las relaciones de parentesco ritual pueden ser vistas, por lo tanto, como un reflejo de las desigualdades existentes, puesto que propician también este tipo de relación contractual jerárquica entre los sectores mestizos y la población mayoritariamente indigena, traspasando incluso las fronteras de un municipio a otro. ${ }^{5}$ De este modo, al mismo tiempo que se manifiesta la asimetria social existente, se propician vinculos interpersonales que rara vez se expresan en el ámbito doméstico de las mayordomias, espacio ritual más claramente indigena y circunscrito al ámbito comunitario de cada municipio. De modo que en este punto la situación difiere de aquella que plantearan Nutini y Bell para el caso de Belén, población nahua del valle tlaxcalteca, al señalar que "la carrera de compadrazgo promedio en Belén muestra que durante su vida, un individuo es invitado a ser compadre aproximadamente tantas veces como él lo solicita a otros" (1989; 64).

Las relaciones de compadrazgo se establecen durante las ceremonias que se desarrollan en los distintos momentos trascendentales del ciclo de vida individual; marcan la transición de los individuos de uno a otro estatus, lo cual las convierte en "ritos de paso", puesto que denotan el cruce de limites entre distintas categorias sociales. Me refiero especialmente a los casos que Nutini y Bell denominan compadrazgo prescriptivo 6 (op. cit.: 61): se trata del compadrazgo adquirido en ocasión del bautizo, la confirmación, la primera comunión, el casamiento y la muerte. La transición individual que implica el paso por esto momentos, es simbolizada entre los nahuas mediante la ceremonia del cambio de indumentaria a cargo de los padrinos.

\footnotetext{
En Atlahuilco -cabecera del municipio- es frecuente, por ejemplo, que se solicite a personas de Tequila, municipio vecino relativamente más próspero, el padrinazgo en las ceremonias de casamiento o bautizo, mientras que los habitantes de las rancherias se dirigen a las familias acomodadas de la cabecera municipal. Este principio persigue el progreso de la persona a través de su reconocimiento y aceptación en distintos ámbitos sociales.

6 Nutini y Bell dencminan tipos de compadrazgo prescriptivo a aquelios que están caracterizados por una fuerte necesidad de acatarlos y por las sanciones religiosas, sociales y económicas en que incurren los individuos que no cumplen con ellos. 
El cambio de indumentaria constituye, desde mi punto de vista y de acuerdo con Hülsewiede (1992) -quien realizó una investigación en el municipio de Tequila-, el acto simbólico de mayor significado en cada uno de estos ritos de pasaje. El paradigma de este tipo de ceremonia se sintetiza en la obligatoriedad de los padrinos de proporcionar todas las prendas de ropa que el individuo usará en el ritual en cuestión. Se invita a los futuros compadres solicitándoles que hagan el favor de "pasar" a su hijo en ocasión de su primera comunión, por ejemplo: "yo tengo gusto que tú pases a mi hijo por la comunión". Si éstos aceptan deberán "vestir" con prendas nuevas al ahijado, asi como a sus parientes más próximos, y hacerse cargo de los gastos correspondientes en la iglesia. Los padrinos son tratados como los invitados principales en los banquetes que se realizan después de la celebración litúrgica; se les halaga con obsequios e innumerables muestras de agradecimiento. En algunos casos el acto de vestir es sólo simbólico, mientras que en otros los padrinos deben de hecho colocar todas las prendas de ropa que obsequian a su ahijado, como ocurre con un bautizo, una novia y un difunto.

El cambio de ropa simboliza pues la transición del individuo de uno a otro estado personal y social. Al mismo tiempo, el ahijado constituye un eslabón entre dos grupos de parientes que a partir de ese momento se relacionan entre si como parientes rituales, con un tipo de obligaciones reciprocas que se extienden al círculo de ambos grupos domésticos durante el resto de sus vidas. La indumentaria representa la investidura simbólica que provee al individuo de la fuerza animica necesaria para trascender su posición actual. El acto de vestir, que materialmente realizan los padrinos, se concibe como una acción de apoyo y de respaldo para la integridad y el desarrollo de la persona: "gracias que ya pasaste a mi hijo por el bautizo", o bien, se hace explicito en la arenga de los padrinos en el momento de cambiar de ropa a un difunto: "recibe esta ropita, que no digan que te mandé desnudo".

Los discursos que dirige el tlayecanke en ocasión de cada uno de estos trances, quien se encuentra al frente de la comitiva de los padrinos, expresan siempre esta noción de ayuda en el pasaje de uno a otro estatus. El tlayecanke, a nombre de los padrinos, da consejos al ahijado o ahijados, si se trata de una pareja de novios, conminando a una actuación congruente con su nueva posición personal en el seno del entorno social.

Dado que el individuo que protagoniza este pasaje en su vida personal, resulta ser el intermediario en el establecimiento de relaciones de compadrazgo entre dos grupos de parientes, el cambio de indumentaria no se restringe a aquél: los padrinos obsequian también prendas a todos sus nuevos parientes rituales, es decir el grupo doméstico de su ahijado. Si les resulta difícil otorgar un atuendo completo para todos, es suficiente con una prenda para cada uno, simbolo de la extensión de la 
relación contractual al circulo personal del ahijado.

En seguida relato de manera sucinta el desarrollo de una ceremonia de padrinazgo de primera comunión, que presencié en Atlahuilco en el verano de 1997. Espero de este modo ilustrar la forma en que se lleva a cabo el establecimiento de los vinculos entre dos grupos de parientes, a partir de la relación de compadrazgo.

Antes de la ceremonia en el templo en la que el niño recibiria el sacramento de la comunión, la madrina (en este caso una mujer sola, madre soltera pero con solvencia moral y relativa holgura económical acudió a la casa de sus nuevos compadres, acompañada de una pequeña comitiva, llevando la ropa nueva y procediendo de inmediato a vestir a su ahijado. Ella y su comitiva fuimos recibidos con el protocolo prescrito para estos casos y un desayuno compuesto de pan, chocolate y un guisado local preparado a base de visceras de gallina. Nos despedimos después del desayuno para reunirnos de nuevo dos horas más tarde en la iglesia, con el niño y sus familiares.

Después de la celebración litúrgica el niño festejado retornó a casa con la comitiva de sus padrinos, ${ }^{7}$ (sus padres y familiares se habian adelantado para preparar el recibimiento). En este momento se sellaría el compromiso entre ambos grupos de parientes mediante un intercambio de xochikoscameh de margaritas blancas.

Unos metros antes de llegar a la casa, la madrina colocó sobre el pecho de su ahijado dos xochikoscameh transversalmente, en forma de X. Adentro de la casa esperaba la familia de los nuevos compadres, con su respectiva comitiva y un banquete consistente en arroz y mole de gallina. En el umbral, los recién llegados colocaron un xochikoscatl a cada uno de los miembros del grupo doméstico de los anfitriones, asi como de nuevo al ahijado, encima de los que llevaba puestos. Los anfitriones sahumaron y bendijeron a toda la comitiva antes de que entráramos por fin a la casa. Una vez adentro, los caseros colocaron un xochikoscatl tanto a los padrinos del niño y su comitiva, como al niño, quien regresaba a casa después de la ceremonia en la iglesia. El ha recibido xochikoscameh de ambas comitivas; lleva ahora seis collares colocados en forma de cruz, mientras que el resto de ambas comitivas sólo lleva uno, colocado en el cuello en forma de un collar convencional. ${ }^{8}$ La superposición de xochicoskameh simboliza la posición del ahijado como punto de confluencia entre ambos grupos de

\footnotetext{
Cabe señalar que para los pobladores de Atlahuilco todo desempeño ceremonial de un individuo debe cumplir dos requisitos indispensables: a) contar con un tlayecanke, encargado de hablar a nombre de los interesados y de dirigiz las secuencias ceremoniales y b) acompañarse de una comitiva integracia por zamiliares, compadres $y / 0$ vecinos.

Lóper Austin (1994, 91) señala gue en la tradición mesoamericana la figura del aspa fue muy importante en la simbologia ritual, se usaban sartales de flores o maiz reventado cruzados sobre el pecho lo cual en su opinión remite a la iconografía de Tamoanchan. 
parientes. Los xochikoscameh se retiran después reciprocamente de una a otra comitiva, quedándose con ellos solamente el niño que ha atravesado por este rito de pasaje.

Se realiza después una danza ceremonial en la que la diada de compadres intercambia cajas de cerveza mientras bailan, sosteniéndolas sobre sus hombros; su contenido se repartirá entre la comitiva de los donadores, de manera que el producto regresa a su punto inicial pero pasando por las manos de los nuevos compadres. En esta danza, acompañada por sones tradicionales de música de cuerdas, se simboliza la intermediación que cumple la diada de compadres entre dos grupos de parientes. Al mismo tiempo, el intercambio de dones idénticos es una metáfora de la relación igualitaria entre ambos grupos de personas, en términos de las obligaciones morales reciprocas recién adquiridas.

El tlayecanke que encabeza la comitiva de la madrina, dirige un discurso antes del banquete, en el cual se arenga al ahijado a comportarse de aqui en delante de manera responsable, de acuerdo a las obligaciones correspondientes a su edad. En seguida los padres ofrecen un discurso de agradecimiento a los padrinos por haber "pasado a su hijo" por este ritual y les piden perdón por las ocasiones reales o posibles, voluntarias o no, en que pudieron haber ofendido a quienes ahora son sus compadres. Es decir, se establece el inicio de una relación altamente respetuosa, a la cual se atribuye un carácter sagrado.

A partir de este momento, la relación de compadrazgo se antepondrá, al menos explicitamente, a las relaciones de parentesco o de afinidad previamente adquiridas, incluso cuando se trata, por ejemplo, de relaciones tan próximas como las que pueden existir entre hermanos quienes, a partir de este momento, se tratarán como compadres. Al mismo tiempo, las relaciones de parentesco ritual, adoptan la prohibición establecida para los parientes consanguineos de relacionarse sexualmente entre si. Es decir, ambos tipos de parentesco se influyen reciprocamente: el parentesco ritual toma del esquema del parentesco consanguíneo la prohibición del incesto, mientras que las relaciones consanguineas o de afinidad anteponen el trato ceremonial correspondiente a su relación de compadrazgo.

Al finalizar el banquete, los anfitriones obsequian a sus nuevos compadres un pollo hervido entero, dos cervezas, dos refrescos embotellados y un recipiente con mole, viandas que éstos convidarán entre sus parientes y compadres que no asistieron a la ceremonia, ampliando asi el alcance de los dones recibidos de la relación de compadrazgo recién adquirida. El no convidar de estos alimentos ceremoniales supone una especie de sanción de carácter moral.

Los padrinos y su circulo de parientes más próximo, contribuyen a 
proveer del sustento social que el individuo requiere para desempeñarse de acuerdo al nuevo estatus adquirido. Constituye un grupo de parientes adicional a sus parientes consanquineos y de afinidad, situación que favorece la ampliación del rango de relaciones sociales e interpersonales, así como las condiciones de respaldo ante futuras situaciones imprevistas.

El reconocimiento y posición social que adquiere el individuo desde temprana edad, se reiteran no sólo en los momentos importantes que acompañan todo su ciclo de vida, sino en la ceremonia de intercambio de dones que se lleva a cabo durante la última fase de la festividad anual de Todos Santos, la tarde del dia dos de noviembre. Esta ceremonia representa también una metáfora de la desigualdad de estatus en el ámbito de las relaciones de poder a partir de la posición económica y social de los dos grupos de parientes rituales. De modo que la relación de parentesco ritual posee una naturaleza ambivalente de igualdad/desigualdad. Su naturaleza igualitaria se expresa en el intercambio de dones idénticos durante la ceremonia de padrinazgo, cuando la diada de compadres intercambia xochikoscameh y cajas de cerveza. La relación de desigualdad se manifiesta durante la Fiesta de Todos Santos, cuando se intercambian dones diferentes.

La fiesta de Todos Santos entre los nahuas es pues un culto de carácter eminentemente doméstico. En éste se honra a los difuntos pero desde una perspectiva que celebra la vida y el periodo que inicia. Más que como un duelo, se vive como una ratificación de los parentescos y amistades, convenios contractuales de solidaridades mutuas y de compromisos reciprocos que podrian recordar el sentido de los obsequios de Navidad en las sociedades de tradición occidental. Este desenlace de la festividad de Todos Santos consiste también en una celebración de las cosechas, del inicio de una temporada de relativa abundancia y de preparación para el periodo de invierno.

Como toda festividad del calendario ceremonial de los nahuas, a ésta se ha asignado también una imagen hacia la cual se celebra su respectiva mayordomia: la Virgen de las Animas, cuyo referente es un lienzo pintado al fresco que ha sido retocado por los pobladores de Atlahuilco y que muestra a una serie de rostros afligidos expiando sus culpas entre las llamas del purgatorio. Una cruz de madera, labrada y pintada de negro, de unos treinta centimetros de altura, permanece colocada frente al lienzo.

Cuando ocurre algún deceso, antes de sepultar el cuerpo en el panteón ubicado en los limites del centro del pueblo, -al cual se trasladan los difuntos desde cualquier punto del municipio- el ataúd de madera se coloca en el suelo, frente a estos dos iconos (la cruz y el lienzo), en el interior del templo. Ahi, frente al ataúd semidescubierto, los dolientes rezan y esperan, sentados también directamente sobre el piso, la bendición del cuerpo antes de trasladarlo al camposanto; ésta se realiza 
por el Sacristán Mayor en ausencia del sacerdote. Después del rezo y la bendición, se ingieren ahi mismo algunos alimentos y aguardiente, para encaminarse posteriormente al panteón que se encuentra a pocos pasos del templo.

Durante las festividades de Todos Santos, además del culto doméstico de recibimiento a las ánimas de los difuntos y del intercambio de dones entre parientes rituales, en la casa del mayordomo de la Virgen de las Animas, se suceden las secuencias ceremoniales relativas a la mayordomía.

\section{d) Las otras fiestas del calendario, continuidad del tiempo ritual.}

En el ciclo festivo mesoamericano se efectuaban según Broda (op. cit.: 13-26), un tipo de celebraciones menores durante los intervalos de las fiestas principales de cada mes. Se conoce poco acerca de estas fiestas puesto que solamente las describió Sahagun, mientras que otros cronistas las confundieron con las fiestas movibles. El carácter de las festividades estuvo lejos de ser homogéneo para toda Mesoamérica, existieron variaciones regionales producto de desarrollos históricos particulares; dichas variaciones y la carencia de información han dificultado tener una visión clara acerca de estas celebraciones que aparentemente fueron de menor relevancia en el calendario ritual prehispánico.

Un principio de jerarquización está siempre presente en el ciclo festivo de los nahuas. Asi como los pobladores de Atlahuilco consideran "fiestas grandes" a las arriba mencionadas, el resto de las festividades, en tanto marcan fechas, fragmentan el tiempo y se suceden en una cronologia establecida. Estas son también jerarquizadas, ubicadas en el conjunto del guión.

A las fiestas antes mencionadas, sigue en importancia otro bloque de celebraciones, distribuidas también a lo largo del año, dedicadas a las siguientes imágenes:

- La Virgen de la Candelaria, el día 2 de febrero, en cuya fiesta se bendice la semilla de maiz que se sembrará hacia la llegada de la primavera. Se trata de una figura femenina asociada a la fertilidad.

- -San José Primero y San José Segundo, el 19 de febrero, en vísperas de la entrada de la primavera y en el inicio de la temporada de siembra. San José cuenta con un doble, como sucede con las imágenes más solicitadas por los patrocinadores de las fiestas. Esta imagen es invocada en el ritual con el cual se inician las labores de siembra.

- La Santa Cruz, el 3 de mayo. Se celebra antes de las primeras lluvias del año y se relaciona con las peticiones de lluvia para los 
cultivos y la bendición de los manantiales de agua.

-La Virgen de la Asunción, el 15 de agosto. Aunque en esta festividad católica se festeja la glorificación de la Virgen María hacia los cielos, después de su muerte física, los nahuas realizan en esta fecha una fiesta dirigida hacia la Virgen en la que se "le acuesta como a un difunto" recordando de nuevo su inclinación hacia el culto a la muerte. Es también una fiesta del reverdecimiento producido por las lluvias del verano. En torno a la imagen de la Virgen en posición horizontal, se colocan racimos de frutas de la temporada. Plátanos y citricos rodean la imagen, mientras que los interiores del santohkalli del mayordomo y del templo donde se celebra la misa, lucen adornados con racimos de frutas que cuelgan del techo y producen la impresión de conjugar la celebración del verano y su fertilidad, preámbulo de las cosechas, con el duelo por el deceso de la Virgen.

Las fiestas menores del calendario son las dedicadas a las siguientes imágenes: ${ }^{9}$

San Sebastián (20 de enero)

Virgen Verónica ( 3 de febrero)

Virgen del Rosario (25 de marzo)

San Martin Caballero de Abril o San Martín Chico (13 de abril)

San Marcos (25 de abril)

San Miguel Aparicio (8 de mayo)

San Isidro (15 de mayo)

Virgen de Mayo (30 de mayo)

Virgen de la Luz (31 de mayo)

San Juan Bautista (24 de junio)

Ascención del Señor (quince dias antes de Corpus)

Sagrado Corazón de Jesús (30 de junio).

Santísima Trinidad (una semana antes de la fiesta de Corpus)

Santo Cristo (1 de julio)

Virgen del Carmen (16 de julio)

Señor del Calvario ( 6 de agosto)

San Lucas (18 de octubre)

Virgen de Guadalupe (12 de diciembre)

Virgen de los Dolores (15 de septiembre)

San Juan Apóstol (27 de diciembre)

Virgen de la Purisima (8 de diciembre)

San Miguel Arcángel (29 de septiembre)

Virgen Natividad (8 de septiembre)

Esta clasificación me fue proporcionada por don Ismael Coxcanua, guien desemoño el puesto de Presidente Eclesiástico durante parios años, incluido el periodo en que razlicé mi trabajo de campo en Atlahuilco. Cotejé la infomación con otras personas que se han desempeñado dentro del sistema de cargos reijiosos, además de confirmarla mediante mi observación personal. 103 
El ciclo anual de celebraciones es pues en Atlahuilco, instrumento de las regularidades, como señalara Balandier al referirse al rito (1990: 31). En una sociedad expuesta a la fragmentación y en un proceso de estratificación creciente, con una diversidad de movimientos migratorios y de lucha de facciones, el ciclo ritual aparece claramente como un medio adaptado a un fin: la imposición de un orden global en el cual se asocian prácticas simbólicas, actividades sociales, individuos $\mathrm{e}$ imágenes de santos.

De este modo, los nahuas consiguen un nivel de regularidad social que liga a los hombres a través de prácticas simbólicas que se sostienen en un ciclo repetitivo, sostenido consensualmente. Se afirma asi una solidaridad fundada en el objetivo de un fin común, la función imaginaria de conseguir la armonia entre la naturaleza, las divinidades y los hombres. El individuo se vincula a través del ritual a su propia sociedad, se sitúa dentro de ella cumpliendo una función mediadora. La dramatización ritual produce un estado colectivo que disuelve las diferencias, una coincidencia en las expectativas acerca de sus resultados.

El ciclo ritual constituye, finalmente, un sistema de comunicación que conjuga distintos lenguajes. Promueve la continuidad a la vez que permite el desarrollo de cada fiesta como un episodio singular, episodio apegado al guión que integra un drama festivo en un flujo continuo y permanente. El cumplimiento de este ciclo proporciona la posibilidad de redistribuir en el presente, mediante una observación siempre actualizada de la sucesión dramática, los acontecimientos que ligan a los hombres con la divinidad, con la naturaleza y entre si mismos. 


\section{INTERCAMBIO DE DONES IDENTICOS DURANTE EL RITUAL DE PADRINAZGO}

\section{(Entrega de Xochikoskatl)}

1) Comitiva de los padrinos __ Ahijado__ Comitiva de los compadres solicitantes

2) Comitiva de los padrinos $========= \pm== \pm==$ Comitiva de los compadres solicitantes

(Obsequio de una caja de cerveza)

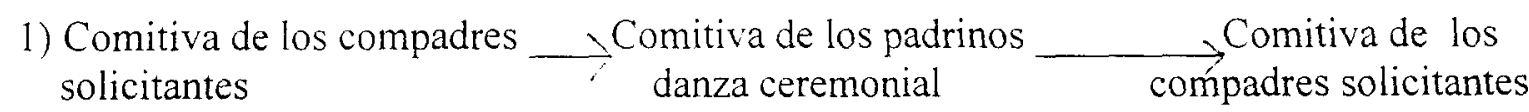

2) Comitiva de los padrinos $\longrightarrow \begin{gathered}\text { Comitiva de los compadres } \\ \text { solicitantes (danza ceremonial) }\end{gathered}$ padrinos 


\section{DESARROLLO DE LAS FIESTAS DEL CICLO RITUAL EN EL CENTRO CEREMONIAL.}

\section{FIESTAS DE RENOVACION DEL CENTRO CEREMONIAL:}

Celebración de vísperas

Procesión con todas las imágenes encabezadas por la imagen festejada

Comida en el atrio ofrecida por todos los mayordomos para todos sus colaboradores

Asistencia de habitantes de las distintas localidades municipales

\section{FIESTAS MENORES:}

Procesión con dos o tres imágenes encabezadas por la imagen festejada.

Comida en el atrio ofrecida por el mayordomo de la imagen festejada para el resto de mayordomos (sin sus colaboradores)

Asistencia del círculo de colaboradores del mayordomo y vecinos de la cabecera municipal. 


\section{CAPITULO IV}

\section{LAS FIESTAS DE MAYORDOMIA: REPRODUCCION DE UN CIRCUITO MULTIPLE DE INTERCAMBIOS.}

En el capitulo anterior, examiné los rituales públicos del ciclo ceremonial de Atlahuilco relacionados con las festividades mayores. En el presente capitulo me propongo abordar la lógica de los planos de interacción y de relaciones de intercambio, propiciados por la celebración de las fiestas que sostienen el ciclo ceremonial. Me interesa mostrar que la realización del ciclo anual de fiestas, genera una forma de organización cuya dinámica ha permitido una interacción entre los distintos segmentos o agrupaciones residenciales que integran el municipio. Por otra parte, argumento que se perfila, al mismo tiempo, una tendencia hacia la autoorganización en el seno de las facciones o microlocalidades, mediante el establecimiento de su propio subsistema de fiestas.

Mientras que el calendario anual de festividades es instrumento de las regularidades, demarcador del tiempo y confirmación de su movimiento cíclico, el ritual de la mayordomia, mediante el cual se sostiene, proyecta una amplia gama de posibilidades de intercambios que demarcan el cuerpo social en su conjunto. Si bien cada una de las fiestas cumple un papel en la organización del tiempo y el espacio, en el nivel pragmático resulta en un sistema de clasificación social, que distribuye las funciones y cargos ceremoniales entre un gran número de personas, en el marco de un elaborado esquema de participación.

A partir de la implementación de cada fiesta, el calendario ceremonial proporciona el marco para la realización de transacciones económicas entre personas y grupos de personas y transacciones simbólicas entre hombres y divinidades. Las rutinas rituales se desarrollan en distintos planos de interacción que se proyectan sobre el ámbito comunal en su conjunto. El sentido de la obligación mutua es expresión de un sentido de pertenencia a un mismo ámbito social. Como señala Balandier (1990: 28-30), el rito tiene una logica propia determinada por su finalidad, se inscribe en el interior de un sistema, que contribuye a la integración individual en una sociedad y una cultura, al mismo tiempo que se refiere a la gestión de lo sagrado, a la manifestación del poder o a todo otro orden social. Consiste en una serie de episodios ordenados, una sucesión de fases durante las cuales se asocian simbolos, iconos, palabras y actividades. EL ciclo ceremonial se sustenta en el desarrollo de secuencias rituales que pueden ser clasificadas en públicas y privadas, no obstante que constituyen en definitiva un "hecho social total", retomando la expresión de Mauss, y son indivisibles en este sentido, puesto que persiguen el mismo fin 
último. El ritual público, sin embargo, aparece como en una posición de umbral entre un espacio abierto y uno cerrado, (Grimes, cit. en Ochiai, 1985: 7) tanto en términos del espacio, como en cuanto a la participación de los individuos involucrados y los requisitos para acceder a determinadas fases de las fiestas.

La mayor parte del desarrollo ceremonial de cada mayordomia o fiesta del calendario se lleva a cabo en un espacio cerrado, en el ámbito doméstico del mayordomo y se circunscribe a un número restringido de personas, así sea, en ocasiones, un grupo bastante numeroso. La fase final de cada fiesta puede ser considerada un ritual público puesto que se lleva a efecto en el centro ceremonial, cuando se extiende la participación al conjunto del cuerpo social. En este capitulo me interesa abordar la fase privada de las fiestas del ciclo ritual de Atlahuilco dedicadas a las imágenes de los santos, asi como su significación en el campo de las transacciones entre las divinidades y los hombres y entre los hombres entre si. Considero que estas fiestas expresan una serie de principios que continuan siendo relevantes en el universo social de los nahuas.

Pretendo ilustrar la idea de que cada ciclo anual constituye una combinación distinta de las unidades domésticas participantes, cuyo objetivo es mantener un ordenamiento. Es decir, su papel es provisional, de manera que las constantes son las relaciones entre los elementos y no los elementos mismos (Levi-Strauss, 1964: 85). Cada celebración o mayordomia desarrolla una secuencia que consiste en una sucesión lógica de representaciones, consta de un principio y un fin bien definidos que permiten un relevo sincronizado de cada uno de los cargos. De ahi que podamos afirmar que en Atlahuilco, cada ciclo anual se integra por ciclos múltiples que conjugan una serie de cadenas sintagmáticas.

Este sistema de relaciones se asemeja a un caleidoscopio, retomando la idea de Levi-Strauss (ibid.) en relación al pensamiento mítico: un proceso continuo de ordenamientos que permite un número muy amplio de combinaciones, en el cual los habitantes de un espacio social delimitado, se integran en una estructura, acogiendo toda contingencia de acuerdo al modelo. Desde esta perspectiva es posible afirmar que el sistema de organización que sostiene el ciclo ceremonial en torno al culto a las imágenes de los santos mediante la rotación de puestos, es un sistema de clasificación y un ejemplo entre otros de clasificación social. E1 ciclo ceremonial anual puede ser visto como el eje horizontal desde el cual se desprenden un número finito de secuencias rituales, encadenadas entre si siguiendo su propio ritmo repetitivo. Se trata de un tipo de ordenamiento que permite elaborar una clasificación social de varias dimensiones, a las que haré referencia en este capitulo.

Como señala Godelier (1989: 89), la condición de la reproducción de un sistema no implica ausencia de contradicciones en su interior, "sino la existencia de una regulación de esas contradicciones que mantenga provisionalmente su unidad". De modo que uno de los objetivos de estas páginas es el de comprender los 
mecanismos de reproducción de este sistema, abordando sus niveles de funcionamiento y de representación, los cuales constituyen, en último término, un sistema de información. Desde mi punto de vista, en la jerarquia de las relaciones sociales, las relativas al sistema de cargos religiosos o mayordomias continuan teniendo un peso relevante en la vida social de los nahuas, especialmente en referencia a las relaciones materiales-ideales de los hombres entre si y con las divinidades (Godelier, op. cit.: 25). No obstante las disrupciones y contradicciones inherentes a todo sistema, considero que cualquier relación de los hombres, entre ellos y con la naturaleza conlleva una parte ideal que juega un papel esencial en la reproducción de dicha relación. Las representaciones normativas constituyen el componente esencial de dichas relaciones. De acuerdo con Godelier (op. cit.: 10), lo ideal es ".. este complejo conjunto de formas, de contenidos, de principios y de niveles mentales que desempeñan un papel esencial en el proceso de producción de la sociedad".

Este conjunto de representaciones engendran una serie de relaciones a partir de su elaboración pragmática. El desarrollo del sistema de cargos religiosos depende de la relación jerárquica entre distintos niveles de organización y de la correlación entre las unidades de cada uno de ellos. Tal y como sucede en el ejercicio discursivo, ningún nivel por si solo puede producir sentido (Barthes, 1990: 10). Comenzaré por el análisis de la participación en el nivel individual.

\section{a) E1 individuo y sus roles actanciales.}

En el capitulo siguiente me refiero a la conformación del individuo nahua desde el punto de vista de las esencias y entidades energéticas que se integran en su persona fisica. En este apartado me interesa señalar algunos aspectos acerca de la configuración de la persona social, misma que supone la incorporación de un conjunto de representaciones colectivas mediante las cuales el individuo asume su identidad personal y su posición con respecto a su grupo social, es decir, se conforma a partir de un conjunto de atributos parentales y de relaciones clasificatorias comunitarias que se configuran por las posiciones sociales que el individuo adquiere a lo largo de su vida.

Desde mi punto de vista, la identidad personal de los nahuas se construye en primera instancia a partir de su posición en el seno de su grupo doméstico. La adscripción residencial es la principal via para la identificación individual. Asi por ejemplo, para una mujer, el cambio de residencia para integrarse a su familia de procreación implica una especie de conmutación gramatical que da lugar a que deje de ser reconocida como la "hija de", para convertirse en la "nuera de" durante la fase de residencia patrilocal en el hogar de su marido. Más tarde ella pasará a ser la "mujer de", una vez que se ha realizado la fase de escisión y se ha ubicado en una residencia aparte. Al unirse al grupo doméstico de su marido, la mujer se dirige hacia su suegra como "mamá" y a sus cuñados como "hermanos", anteponiéndose asi el criterio de residencia sobre el de 
afinidad. Este tipo de trato desaparece una vez que se realiza la fase de escisión y la nueva pareja establece su residencia aparte.

En la concepción nahua, es predominante pues el hecho de concebir al individuo a partir de su posición en el seno de un grupo doméstico, denotando el espacio fisico donde habita, pero también en función de su actuación o desempeño en su entorno social, es decir, en una especie de sintesis entre el individuo y la colectividad. Esta concepción se manifiesta en distintas facetas de la vida cotidiana, tal y como sintetiza Soustelle (1958: 229) en su monografia de Tequila:

"Toute personne importante doit etre acompagnée". Si bien este principio se aprecia especialmente en las ocasiones rituales, está presente en todo momento; lo percibi con claridad mientras realizaba trabajo de campo, deambulando solitariamente de un lado a otro del poblado e incluso desplazándome por el entorno más amplio. No pasaron muchos dias antes de que las personas con quienes había adquirido una relación cercana, me sugirieran insistentemente conseguir un acompañante, de preferencia un niño o una joven. Dado que no siempre me fue posible caminar acompañada, aprecié entonces una sensación de estarme comportando de manera excéntrica, como si transgrediera una forma rigurosa de presentación. Es notorio este requisito especialmente para las mujeres, quienes por esa razón generalmente realizan sus diligencias fuera del hogar en compañia de otra persona.

Este protocolo de presentación individual se ve claramente acentuado en las ocasiones de desempeño ceremonial. Si bien éste se expresa en términos de una responsabilidad personal, adquirida por ejemplo para fungir como mayordomo de una imagen religiosa o como padrino de bautizo, resulta inconcebible que el responsable del "compromiso" aparezca sólo -o incluso acompañado únicamente por su cónyuge- en los episodios rituales correspondientes. En todos los casos y en cada una de las secuencias rituales, se requiere por lo menos de la presencia del grupo doméstico en pleno y de una o más parejas de compadres, vecinos o familiares. Por otra parte, todo individuo en trance de desempeñar una papel ceremonial protagónico, requiere de un representante especial para estos casos, el Tlayecanke, especialista ritual que hablará a su nombre y guiará todas las fases del ceremonial. Este requisito de acompañamiento se extiende a las imágenes de los santos, como señalo más adelante.

Los apodos o motes son una forma común entre los nahuas de identificar a un individuo en sustitución de su nombre propio. Generalmente se adjudican a partir de alguna característica fisica, alguna anécdota o algún rasgo de su carácter, por ejemplo Juan Pollo o Martin Kuino (de kuini, bebedor), y se convierten en la principal via de identificación, hasta el grado de olvidarse del nombre verdadero. De modo que la identidad individual de los nahuas se encuentra signada alternativamente por un nombre secreto ${ }^{1}$, un nombre

\footnotetext{
El nombre secreto es usado como ina forma de proteger la identidad individual. Observé esta tendencia principaimente entre mujeres y niños, a
} 
público, en ocasiones un apodo y uno o dos apellidos, los cuales en un gran número de casos son de origen nahua. En la cabecera municipal de Atlahuilco, registré que el setenta por ciento de los apellidos son nahuas, el treinta por ciento restante lo componen apellidos españoles como Montalvo, Cano, Juárez y Hernández.

Es notorio, el predominio de ciertos apellidos en cada municipio de la Sierra, lo cual sugiere una posible tendencia hacia la endogamia municipal. Por ejemplo, entre muchos otros, en Texhuacan son comunes los apellidos Ayohua (los que tienen agua), los Tepole (de tepolo, vencedor), los Quiahua (de quiawi, lluvia), los Gálvez y los Hernández, descendientes -estos últimos- de una inmigración de la vecina serrania poblana conocida como Sierra Negra hacia principios del siglo XX. En San Andrés Mixtla, residen los Xochiquiquisqui, los Xalamihua (de xalli, arena y ath, agua) y los Tlaxcaltecatl. Mientras que en Atlahuilco, se encuentran los Kuixi (gavilán) los Cozcahua (de coskath, collar), los Molohua, (de molotl, pajarillo), los Lxmatlahua, entre otros. En algunos casos, los topónimos residenciales, refieren la identificación de quienes habitan en un punto o paraje específico, por ejemplo se denomina Moloka al sitio donde habitan los Molohua. En otros, el topónimo considera las caracteristicas fisicas del terreno, por ejemplo, Zacatla, lugar donde hay zacate (ambos son parajes de Atlahuilco).

Al interior de los hogares no existe la intimidad individual. El reducido espacio interior es compartido por todos los miembros del grupo doméstico. Sin embargo, parece deseable el propiciar en la medida de lo posible una disposición de las viviendas que permita cierta intimidad en relación con otros grupos domésticos. Se conservan cercas vivas y se orientan las casas de manera que queden semicubiertas por los accidentes del terreno, como peñascos y elevaciones, lo cual por otra parte, resulta casi inevitable bajo las condiciones topográficas serranas. De este modo, cada vivienda o agrupación patrilocal de viviendas, se conecta con otras a través de una fina malla de senderos, a veces imperceptible para el extraño, especialmente en los parajes y áreas distantes del centro del poblado. Es común que el visitante recorra alguna distancia considerable entre una y otra residencia, y que una extensión de ésta sea la exclusiva para acceder a un hogar.

Esta disposición posibilita que los moradores noten desde la distancia cualquier visita inminente y se preparen en la medida de lo posible, a veces simulando su ausencia. A pesar de que el visitante sabe que los moradores han percibido su presencia desde varios metros atrás, se anunciará estando próximo a la puerta de manera sutil, tosiendo y alejando a los perros guardianes. Aquellos aparentan total ignorancia de la visita, hasta escuchar el saludo formal que consiste en un

quienes se considera de naturaleza "débil". Consiste en el uso cotidiano de un nombre distinto al que aparece registrado en el acta de bautizo y de nacimiento. 
suave y entonado "chikawatika", que se contestará desde dentro con la misma intensidad, fingiendo algo de sorpresa. Los tablones de madera que conforman los muros de la casa indigena, permiten a sus habitantes el control de sucesos de este tipo, como el movimiento de vecinos y forasteros por su entorno inmediato

La aparente discreción en la persona de los nahuas es una conducta pautada, expresada en el andar, el habla, el saludo y los gestos, y desde mi punto de vista es la manera en que se expresa un severo control social sobre los individuos. Sin embargo, son aceptables las disrupciones de este ritmo gestual y verbal si éstas se dan a causa de la embriaguez alcohólica, tal y como refiere Pitarch (op. cit.: 129) que ocurre entre los tzeltales, puesto que se entiende que "uno mismo no es responsable de uno mismo enajenado". Puede estarse desarrollando, el momento más álgido de una secuencia ritual, como el discurso de un Tlayekanke en representación de un padrino de bodas, dirigido a los recién casados acerca de los sus deberes adquiridos, mientras a un lado de la pareja dos hombres bailan entre sí golpeando el suelo con sus pies de forma estrepitosa y algún otro yace dormido doblado sobre si mismo. La embriaguez es una exigencia ritual en ciertas ceremonias; es usual dar de beber cerveza o aguardiente a los niños desde que son pequeños, con el fin de que adquieran resistencia y puedan en el futuro desempeñar sus cargos de manera adecuada.

La discreción gestual y corporal se impone en el desempeño público de las personas, sin embargo, en el seno de los hogares o en el marco de una reunión social no se escatiman los comentarios acerca de los otros, las burlas y motes jocosos, la envidia por sus posesiones y la severa censura sobre su vida intima. Aún cuando nadie parece observar abiertamente el comportamiento del resto de la gente, se toman en cuenta todos los detalles de éste. De modo que para determinados asuntos es preferible movilizarse fuera del hogar una vez que empieza a caer la tarde o bien entrada la noche, cuando el desplazamiento por los senderos puede realizarse de forma discreta. Es el caso, por ejemplo, de las gestiones necesarias para solicitar la mano de una joven, petición que se lleva a efecto en las primeras horas de la madrugada, esperando asi que la discreción enmarque acontecimientos que pudieran generar habladurias y afectar la integridad social de alguno de los involucrados.

Es especialmente rigido el control sobre la conducta femenina, lo cual expresa una fuerte asimetria en las relaciones entre los sexos. En Atlahuilco, las mujeres acusadas de adulterio son castigadas severamente: a las agresiones fisicas y verbales de parte del marido ofendido, sigue una segregación social que muchas veces culmina con la expulsión. En algunos casos, la mujer es recluida de por vida en la casa paterna con la absoluta prohibición de presentarse públicamente, entregada exclusivamente al trabajo doméstico y con un estigma sobre su persona que permanecerá para siempre. Una vez comprometida en matrimonio, una joven tiene la prohibición explícita de salir de su casa, no se le permite 
asistir a ningún tipo de evento social ni realizar encargos incluso dentro del mismo poblado. Es común que a las mujeres casadas en edad reproductiva tampoco se les permita ausentarse del hogar si el marido se encuentra ausente. Permanecen recluidas, dedicadas a las labores domésticas y a la crianza de animales de traspatio, mientras sus cónyuges permanecen en las plantaciones de las zonas cálidas o en las ciudades.

Las jóvenes son cuidadosamente vigiladas en su comportamiento habitual, puesto que un acercamiento a un hombre en edad adulta, aunque sea solamente verbal y de carácter ocasional, es decir, un intercambio de palabras, puede ser interpretado como el establecimiento de un compromiso entre ambos. Si éste no culmina con la unión conyugal, dificilmente puede esperarse que la muchacha sea solicitada en el futuro para unirse formalmente a otro hombre. Una vez contraida una relación de este tipo, la mujer en edad reproductiva es celosamente vigilada, dedicándose a la procreación durante toda esa etapa de su vida. Siempre tendrá obligaciones dentro de su hogar, y un bebé a quien amamantar, a quien llevará permanentemente en su seno, como un marcador inseparable de su condición social.

La conducta sexual de los hombres, sin embargo, es mucho más laxa: se dan casos de poliginia - a veces de tipo sororal- y la procreación con distintas mujeres aunque no todas funjan como esposas. Aunque hoy en dia, las instituciones educativas y las experiencias recientes de los jovenes nahuas, han propiciado espacios para una continua reelaboración de las relaciones entre los sexos, éstas se encuentran aún altamente reguladas, lo cual no impide una gran variedad de formas de transgresión. Las jóvenes que se acercan a los patrones urbanos de comportamiento en sus relaciones de noviazgo o de amistad con jóvenes del sexo opuesto, no se ven aún libres de la fuerza de estos mecanismos de control y parecieran encontrarse oscilantes entre distintos valores, en una especie de "zona de peligro".

Los banquetes ceremoniales son la escena ideal para comprender los roles femeninos y sus cambios de una posición a otra. Estas celebraciones que se llevan a cabo en los espacios domésticos por diversos motivos, requieren la colaboración de las mujeres para las tareas de la cocina. Si éstas se encuentran en la etapa biológica reproductiva, aún cuando sean solteras, se abstienen de participar en las actividades que se llevan a cabo en el santohkalli, el espacio destinado a recibir a los invitados, colocar las imágenes de los santos, servir los alimentos y realizar las danzas ceremoniales (salvo si forman parte del grupo doméstico anfitrión o llegan como parte de alguna comitiva especial). En contraste, las mujeres mayores cuentan con la absoluta aprobación para desenvolverse libremente en dichos contextos. En reconocimiento a su condición, se les asignan labores sencillas como mecer las hamacas improvisadas donde descansan los bebés de las cocineras, o el escanciamiento de aguardiente para aliviar lo arduo del trabajo junto al fuego. Ellas toman la iniciativa de inaugurar 
la danza que forma parte de distintos desarrollos rituales y cuentan con la aprobación para bailar y beber cuanto asi lo deseen durante toda la fiesta, es decir, los ancianos se benefician de la excepción notoria de una serie de reglas de prohibicion.

Las fiestas de mayordomia constituyen de este modo, espacios para recordar y reafirmar los limites precisos de las categorias de edad y género. Evocan las palabras que utilizara Duverger para sugerir las tonalidades del comportamiento mexica:

"tanto como el gesto es medido, tanto asi se expande la palabra... a cada estado corresponde una actitud, un comportamiento bien definido. Asi pues para no perturbar la red semiótica, el gesto utilitario debe pasar absolutamente inadvertido, es decir, reducirse a lo eficaz" $(1983,59)$.

De ahi la importancia de las fórmulas discursivas empleadas por el Tlayekanke, y de su vigilancia del cumplimiento de las reglas de cortesia y de los procedimientos prescritos.

El circulo de parientes rituales en torno a un individuo, quien resulta ser el vínculo entre dos grupos domésticos, se conforma desde el momento en que es bautizado y se reafirma en lo sucesivo, en las distintas etapas de su vida. Las obligaciones generadas por este tipo de vínculo son de carácter vitalicio y generan obligaciones de tipo moral así como la prohibición de relacionarse sexualmente entre si. Es decir, el parentesco ritual toma del esquema de parentesco consanguineo la prohibición del incesto, mientras que las realciones consanguineas o de afinidad anteponen el trato ceremonial, siempre que es el caso, correspondiente a su relación de compadrazgo. Este tipo de parentesco proporciona al individuo un grupo de parientes adicional a sus parientes consanguíneos y afines, situación que favorece la ampliación del rango de relaciones sociales e interpersonales, asi como las condiciones de respaldo ante futuras situaciones imprevistas.

De modo que el individuo se define socialmente a partir de su posición en tres circulos de parentesco: el de su familia de orientación, el de su familia de procreación y el de sus parientes rituales. En el trato que se otorga a los parientes afines cuando se comparte la residencia, se adopta el modelo de la familia de orientación, pero el trato de parientes rituales se sobrepone siempre que es el caso, sobre el de afinidad y consanguinidad.

Durante la vida adulta, la participación en la vida ceremonial denota significativamente el rol actancial del individuo. En los asuntos de carácter ritual, se espera que se cumpla con un comportamiento altamente institucionalizado y uniforme, y toda transgresión es comentada con agudeza, especialmente en lo referente a los dones protocolarios que se estilan en un 
banquete ritual, o en los procedimientos de etiqueta de los cuales los nahuas son celosos vigilantes.

Es común que las familias mestizas residentes en la cabecera municipal de Atlahuilco se abstengan de solicitar cargos como mayordomos, -aunque no se trata de una regla estricta- dado que la fiesta de mayordomia que se realiza en el espacio doméstico del mayordomo es un ritual más bien indígena, al cual algunos mestizos asisten ocasionalmente como invitados. Este sector de la población participa en determinadas secuencias ceremoniales del ciclo ritual anual del sistema de cargos, especialmente en las procesiones y misas celebradas en el templo. En contraste, es notable su injerencia dentro de las redes sociales establecidas mediante los vinculos de parentesco ritual, relación que permite expresar la posición jerárquica de los grupos domésticos involucrados, misma que se manifiesta, como señalé en el capitulo anterior, durante la fiesta de Todos Santos.

Entre la población mayoritaria de Atlahuilco, los puestos en el sistema de cargos religiosos continúan funcionando como una fuente de prestigio social, aunque es preciso reconocer que en determinados sectores de las generaciones jóvenes se gesta una posición critica en relación al excesivo ritualismo y dispendio que ello implica. Dicho sistema, aún cuando no constituye una escala ascendente, denota la capacidad de los individuos para solventar un gasto y para acceder a una fina malla de intercambios reciprocos y de circulación de dones que implican aceptación y reconocimiento social y que requieren de cierta solvencia económica. Un individuo intentará acceder por primera vez a este sistema de relaciones en el momento de su vida en que se asume con las condiciones necesarias para desempeñarlo, generalmente una vez que se ha realizado la fase de escisión de la residencia patrilocal ${ }^{2}$, aunque ello puede ocurrir también aún encontrándose formando parte de una familia extendida.

Si bien en Atlahuilco han desaparecido los cargos civiles tradicionales bajo el llamado sistema de escala, herencia de las formas de gobierno colonial, en Tlaquilpa, municipio limitrofe, sigue vigente esta carrera de servicio en la cual se manifiesta una concepción que no distingue entre los asuntos relacionados con los cuidados del templo y la supervisión del cumplimiento de las fiestas religiosas y el servicio en el ámbito del gobierno civil. ${ }^{3}$ Tanto en Atlahuilco como

\footnotetext{
Como señaié páginas atrás, en la mayoría de los casos, la pareja continúa compartiendo el espacio patrilocal como familia extensa no resiciencial, siguiendo la terminologia propuesta por Nutini (1974), es decir, con techo y fogón independientes pero compartiendo el solar y alguros espacios comunes como el lavadero, la letrina, los corrales y en general el sclar doméstico. En otros casos, casi siempre cuando el marido es el hijo meror o xokoyote, se continúa indefinidamente como familia extensa residencial, compartiendo techo y fogón en la residencia patrilocal. En otros más se adquiere un solar totalmente independiente del espacio patrilocal, casi siempre a consecuencia de la falta de espacio para construir una nueva casa-habitación en el mismo solar.

3 En Talquilpa la escala de servicio es la siguiente, en orden ascendente:

-seis topiles, encargados de llevar mensajes,
} 
en Texhuacan, no obstante, se manifiesta una eficiente organización de la población para los asuntos relacionados con el cuidado del templo y la observancia del ciclo de fiestas religiosas, pero con una noción de que la participación debe ser voluntaria; la idea de un servicio obligatorio y gratuito ha dejado de ser un principio operante para la actuación social del individuo.

Los ancianos y personas mayores recuerdan con nostalgia que en su juventud los hombres se veian obligados a participar en los puestos de gobierno, después de haber pasado por una escala de servicio, desde el puesto de topil (mensajero o ayudante) hasta el de presidente municipal. La elección se fundamentaba en la carrera pública de cada persona y no habia más retribución que la convicción de haber servido a la comunidad. Lamentan la apatia e indiferencia para prestar el tequio o faena, forma de organización que coordinaba los esfuerzos individuales de los hombres en edad adulta para colaborar en trabajos de beneficio colectivo: "ya no hay respeto, ya no nos obedecemos, ya nadie toca el tambor, ya nadie nos llama, ya no hay fuerza... ya nadie limpia los caminos, parecen caminos de conejos". ${ }^{4}$

Desde su punto de vista, esta actitud de las nuevas generaciones es consecuencia de la modalidad de retribuir económicamente a los funcionarios del cabildo; mientras que anteriormente el común del pueblo proponía a los funcionarios principales del gobierno, hoy éstos se autoproponen con miras a la obtención de un beneficio personal.

Hoy en dia, por consiguiente, se reelaboran las categorias de definición de los individuos en el marco de una complejidad de procesos en los que intervienen factores como la educación formal, las migraciones y la diversificación de los mercados de trabajo. Son evidentes las contradicciones y diferencias internas, si bien algunas de ellas tienden a conciliarse.

- seis mayores o policias,

- seis tekimaitl, encargados de apoyar en las labores de organización de las

faenas o trabajo colectivo,

- dos sacristanes, encargados de cuidar el templo, el curato, apoyar al

sacerdote y supervisar que se cumplan los cargos religiosos relativos a las

fiestas de mayordomia,

dos fiscales, asignados a las labores de entierros y funerales,

-seis tekitalhtomeh, responsables de organizar al pueblo en diferentes

actividades de interés común, como la elección de nuevos funcionarios,

gestiones públicas y organización del trabajo colectivo.

Estas inquietudes fueron expresadas en una reunión celebrada en San Juan

Texhuacan, el 28 de septiemore de 1999, organizada por la Radio Indigenista de la Sierra de Zongolica. Hasta hace pocas décadas, un funcionario llamado en algunos lugares tekitalhto y en otros tekimaitl, recorría su localidad tañendo un tambor, conminando a los habitantes a sumarse a las labores de la faena o trabajo colectivo que se realizaba una vez a la semana. 


\section{b) La mayordomia: componentes y secuencias ceremoniales.}

En este apartado describiré los componentes básicos de la mayordomía, tanto en referencia a los participantes como a las secuencias ceremoniales, que en términos de Galinier (op. cit.: 29) pueden entenderse como las unidades constructivas básicas a partir de las cuales se descubre la arquitectura simbólica del sistema ritual. Se conoce como "fiesta de mayordomia" al conjunto de secuencias ceremoniales desarrolladas en los hogares de los mayordomos o anfitriones de las fiestas, dedicadas a las imágenes de los santos que se encuentran en el interior de los templos y capillas.

En Atlahuilco intervienen los siguientes funcionarios en el desarrollo de toda mayordomia ${ }^{5}$ :

Presidente Eclesiástico o Lector, responsable de coordinar el desarrollo del ciclo ritual anual y de la observancia de cada una de las fiestas, asi como de asignar formalmente los cargos a los mayordomos al inicio de cada año, en la ceremonia de Año Nuevo. Este puesto se considera de gran responsabilidad y puede prolongarse indefinidamente, en tanto el responsable cumpla cabalmente con sus funciones. Este funcionario es elegido por el pleno de los cargueros, considerando sus méritos en el desempeño de otros cargos ceremoniales. Quien acepta este puesto asume el compromiso de estar presente en todas las fiestas del calendario anual, asi como cada domingo en el templo, dia en que los mayordomos acuden para visitar a sus respectivas imágenes y sustituir las flores y las ceras y se tratan asuntos de interés común.

Sacristanes, encargados del templo. Este grupo de funcionarios, se integra por un Sacristán Mayor y doce Sacristanes Menores o Semaneros, responsables de resguardar el templo, recibir al sacerdote, colaborar en los oficios religiosos, asi como de tocar las campanas de la torre de la iglesia, señalando el paso del tiempo y los decesos ocurridos en cualquier punto del municipio. Mientras que el de Sacristán Mayor es un puesto de prestigio que implica una erogación significativa debido a la responsabilidad de financiar la fiesta de Año Nuevo, el de los Semaneros se considera como un puesto de servicio a la comunidad, asignado a los jóvenes como iniciación en los asuntos religiosos.

Mayordomos, responsables individuales de celebrar las fiestas en honor de las imágenes de los santos; aparecen como tales en las listas de espera que guarda el Presidente Eclesiástico o Lector, sin embargo, se asume implicitamente que su

\footnotetext{
Somo he mencionaco, en la sierra de Zongoiica cada pueblo organiza su ciclo ceremonial de acuerdo a su sarto vatrón $y$ a las imágenes existentes en el templo principai $y$ en las capillas de jas rancherias y congregaciones. De modo que en cada municipio, la organización de las mayordomias se presenta con algunas variantes, tanto en ei desarrollo del ceremonial como en cuanto a los funcicnarios $y$ los puestos correspondientes. Aquí planteo la información referente al municipio de Atlahuilco.
} 
grupo doméstico comparte también el compromiso adquirido. Las secuencias ceremoniales prescritas en la mayordomía establecen un importante rol actancial a la cónyuge del mayordomo, puesto que idealmente éste debe ser un jefe de familia. No obstante, hoy en dia es común que asuma el cargo algún joven soltero apoyado por su familia de orientación, o bien alguna mujer viuda, apoyada por su familia de procreación. En estos casos, algún miembro del grupo doméstico de sexo opuesto al del mayordomo o mayordoma asume el rol prescrito para el cónyuge.

Tlayekanke o especialista ritual $^{6}$, encargado de guiar el desarrollo de las ceremonias y de hablar a nombre de los anfitriones de las fiestas. Se trata de un especialista en el manejo de las fórmulas orales mediante las cuales se obtiene el efecto simbólico caracteristico de determinados contextos rituales; controla también otros elementos del proceso ritual total. Este funcionario es acompañado por su cónyuge en todos los casos, puesto que existe una distribución de las actividades asignadas para cada uno de ellos. Ella se hace cargo de dirigir y coordinar las labores de la cocina desde el momento de preparación de los banquetes hasta que se sirve a los invitados, mientras que él se encarga de los procedimientos que tienen lugar fuera de la cocina, aunque se relacionen también con la preparación de los alimentos. Dirige a los hombres de la casa anfitriona desde el momento de los preparativos relacionados con la manutención de fogones, disposición de agua suficiente, destazamiento de los animales sacrificados, adquisición de los elementos indispensables, distribución de tareas, etc. También dirige el recibimiento a los visitantes de acuerdo a la etiqueta, hace los discursos y, en suma, esta presente en todo el curso de la fiesta como organizador y representante de los mayordomos y guia de las ceremonias. Los Tlayekankemeh son personas que han pasado por diversos cargos a lo largo de su vida y cuentan con solvencia moral y experiencia en los procedimientos rituales. Todo individuo que asume el compromiso de desempeñar un cargo como mayordomo, solicita de inmediato el apoyo de alguno de estos especialistas rituales para que funja como tal durante el año de su gestión. Un hombre y su cónyuge pueden llegar a ser Tlayekankemeh por el solo hecho de ser invitados para serlo, acto que constituye por si mismo, el reconocimiento de que cuentan con los requisitos indispensables para ello. Cada localidad cuenta con un número restringido de personas que son reconocidas como las idóneas para desempeñar este puesto, razón por la cual son invitadas con frecuencia por los mayordomos y han integrado esta actividad como parte de sus labores cotidianas, puesto que a lo largo del año deben asistir a numerosos banquetes. Constituye un oficio remunerado que permite a estos especialistas rituales sacrificar su tiempo de trabajo asignado a otras tareas, puesto que reciben alimentación y a veces hasta hospedaje durante todos los dias que se

\footnotetext{
Yecaki significa aprobar; Tlayecanke es el que aprueba algo, de ahí que el término se aplique a aquellos funcionarios cuya obligación es la de supervisar y guiar los procedimientos rituales de la mayordomía. En Texhuacan se denomina a este personaje Weweche, anciano $y$ en Mixtla, Teachka, el que manda.
} 
realiza la preparación y realización de las fiestas. Se les obsequia, además, considerables porciones de comida una vez concluida la fiesta, como pago por sus servicios.

Teachkameh $\boldsymbol{h}^{\mathbf{7}}$ o colaboradores de los mayordomos. Este grupo de funcionarios es elegido por cada mayordomo antes de iniciar su gestión, para que colabore económicamente para el banquete que se sirve en la vispera de entrega del cargo. La aportación económica es fija y da derecho a cada teachka y su cónyuge a asistir a banquetes y secuencias ceremoniales que se desarrollan desde el momento en que el mayordomo asume el cargo hasta un año después, cuando lo entrega. Son atendidos especialmente durante la fiesta que se lleva a cabo en la vispera de entrega del cargo, puesto que es entonces cuando se sirven las porciones de la res u otro(s) animal(es) sacrificado(s) en los cuales se invierte su cooperación. Se considera un honor ser invitado como teachka, puesto que ello implica su inclusión y aceptación en un círculo de alianzas parentales y de compadrazgos, al mismo tiempo que se reconoce su capacidad económica. Algunos de los teachkameh realizan su aportación en especie, haciéndose cargo por ejemplo, de adquirir las flores para el santhokalli y para la procesion el dia de la entrega del cargo, o una dotación de cajas de cerveza. Es frecuente que se ponga en práctica un sistema de préstamos a plazo, de modo que quien compra las flores, por ejemplo, recibe la devolución del mismo producto por el mayordomo que lo recibió, cuando a su vez aquel tenga necesidad de desempeñar un cargo similar, aunque sea a varios años a futuro. Un grupo de mujeres colabora con fuerza de trabajo en los preparativos de los banquetes, mientras que un grupo de hombres lo hace en el acarreo de leña, agua, acondicionamiento de fogones y destazamiento de animales.

Taltekimait $\mathbf{~}^{\mathbf{B}}$ o colaboradores especiales de los mayordomos. Este tipo de colaboración es requerida para la realización de las mayordomias que se celebran durante las fiestas de renovación del centro ceremonial, dado que éstas requieren una mayor erogación económica. Casi siempre se requiere su colaboración en especie, financiando la música de banda, las luces de bengala o la atención y pago a los grupos de danzantes. A menudo esta ayuda responde tambièn a una deuda contraida con anterioridad, en la cual el donante fue quien ahora funge como mayordomo. Cada Tlatekimaitl invita a su vez a sus Teachkame o circulo de colaboradores, a quienes solicita una aportación económica para solventar el compromiso adquirido.

\section{Puestos especiales para las fiestas de Semana Santa:}

\footnotetext{
Teachka viene de achkauhtli, mandar, conducir, dirigir. Teachka significa jefe, superior, hermano mayor, se aplica como término honorífico para nombrar a los funcionarios que intervienen en las secuencias ceremoniales de la mayordomía y de todo ritual de pasaje de un estatus a otro, como el bautizo, la primera comunión y el matrimonio.

Tekitl significa tributo, trabajo, cargo; maitl, mano, brazo o rama.
} 
Fiscal: responsable de colocar enramadas para las procesiones del domingo de Ramos y del Via-Crucis que se lleva a cabo el Viernes Santo.

Tekitlahto9: encargado de preparar y servir la cena del Jueves Santo. Cuenta también con su Tlayekanke y su grupo de Teachkame.

Apóstoles: Grupo integrado por doce hombres solteros que representan a los apóstoles y hacen su aparición en las celebraciones de la Semana Santa a partir del Jueves Santo. Los Doce Apóstoles son comandados por un Apóstol Mayor, quien se hace cargo de reclutar a los jóvenes y de guiarlos a lo largo de su participación, apareciendo con ellos en escena. Les ofrece un banquete al inicio y al final de su gestión para lo cual cuenta también con un grupo de Teachkame. El de Apóstol Mayor es un cargo que puede prolongarse durante varios años, siempre que no haya alguien más que lo solicite. En Atlahuilco, don Remigio Molohua llevó este cargo durante doce años consecutivos.

Judios: Este grupo está integrado por ocho hombre adultos (jurios grandes) y cuatro niños (jurios chicos), quienes participan en la representación de la Crucifixión el Viernes Santo.

Músicos y danzantes. Toda fiesta de mayordomia cuenta por lo menos con un grupo de dos o tres músicos de cuerda (generalmente violin y/o guitarra y guitarrón), quienes interpretan sones tradicionales en determinados momentos de la secuencia ceremonial, ubicados siempre a un costado del altar. Son contratados también para amenizar otros momentos de la fiesta en el santohkalli; se acostumbra bailar al ritmo de estas melodias (existen dos o tres grupos de estos músicos en el municipio de Atlahuilco, uno de ellos de la rancheria Ticonca). Por otra parte, en ocasion de las festividades importantes 0 cuando el mayordomo asi lo decide, se contrata a una banda de música de viento, casi siempre procedente de Tequila, la cual se ubica generalmente fuera del santohkalli por razones de espacio; en momentos toca simultáneamente con los músicos de cuerdas. Un grupo de danzantes suele estar presente durante las fiestas principales; puede ser cualquiera de los tres grupos de danzantes que existen en Atlahuilco: los Moros de la congregación Atlehuaya, una similar integrada por jóvenes del paraje de Atlahuilapa, u otra llamada de Tocotines, de la congregación Quechulingo.

Como puede apreciarse, durante el desarrollo de cada fiesta de mayordomía, interviene un gran número de personas, aún considerando únicamente las secuencias que se llevan a cabo en los hogares de los mayordomos:

-42 grupos domésticos de los mayordomos (sin contar las fiestas dedicadas a las Este puesto, como en otras iocalidades de la sierra e incluso de otras
regiones de Mexico, se refería a la actividad de organizar el trabajo
colectivo; en Atlahuilco se transformó en un cargo ceremonial. 
imágenes de las capillas de las congregaciones: una en Atetekochko, nueve en Zacamilola, tres en Atlehuaya y cinco en Acultzinapa, en las cuales sólo participa la gente de su localidad).

-Un grupo de Teachkameh para cada una de las mayordomias. El número de invitados para participar en este puesto es variable, dependiendo de las posibilidades del mayordomo y de la importancia de su fiesta (pueden ser entre diez y incuenta las parejas invitadas). Mientras más Teachkameh colaboren económicamente, se contará con mayores ingresos para solventar el banquete de entrega del cargo, sin embargo, ello también implica que se les debe atender en otras secuencias de la fiesta para las cuales no se utiliza su cooperación. Considerando en promedio la participación de sólo diez parejas de Teachkameh para cada una de las cuarenta y dos fiestas del calendario anual de Atlahuilco, se acumula la cantidad de 840 personas participando anualmente con este puesto.

-Por lo menos dos Tlatekimaitl -y sus correspondientes grupos domésticospara las cinco festividades principales, más su respectivo grupo de Teachkameh

-Los Trece Apóstoles más el grupo de Teachkameh que colabora con el Apóstol Mayor para el desempeño anual de su cargo.

-Un grupo de doce judios.

-Un fiscal

-Un Tekitlahto y su circulo de Teachkameh

- el Sacristán Mayor y su circulo de Teachkameh

-Doce Sacristanes Menores o. Semaneros.

La suma de todos estos participantes, nos da una cantidad que representa aproximadamente al quince por ciento de la población total del municipio, involucrada anualmente de manera directa en el sostenimiento del ciclo ceremonial. Debemos recordar que estos puestos son rotativos; de este modo se consigue la participación anual de un número significativo de grupos domésticos en el circuito de los comportamientos rituales y económicos.

Durante el recibimiento de un cargo como mayordomo de una imagen, se realiza un ceremonial que dura siete dias, mientras que en la fiesta de la entrega se realizan celebraciones durante diez días, es decir, en cada una de las cuarenta y dos mayordomias que dependen de las imágenes de santos que se localizan en la cabecera del municipio, se invierten diecisiete dias al año. Cuando en un hogar 
se están celebrando las secuencias ceremoniales relacionadas con el recibimiento del cargo como mayordomo de una imagen, en otro se preparan para la culminación de la entrega del mismo.

A continuación, presentaré el desarrollo de este sistema de sucesión y encadenamiento de las festividades a lo largo del ciclo anual, asi como mi interpretación acerca del mismo. Iniciaré por la descripción de la mayordomia y sus secuencias rituales, las cuales tienen su propia coherencia y organización interna, aún cuando se desarrollan en el contexto de dramas ceremoniales largos. Como afirma Vogt:

"A medida que un episodio se desarrolla revela un conjunto de acciones simbólicas que, comparadas, descubren los elementos básicos de las ceremonias complejas. Estos conjuntos de acciones están sujetos a los mismos principios básicos de organización que caracterizan a los dramas ceremoniales largos". $(1979,56)$

Toda fiesta de mayordomia se integra por un grupo de participantes que cubren los puestos básicos, indispensables en el desarrollo del ceremonial:

. El mayordomo y su cónyuge, cubriendo el principal rol actancial de anfitriones de la fiesta.

.La pareja de Tlayekankemeh, especialistas rituales.

.El grupo de colaboradores o Teachkameh

.Dos o más Tlatekimatil en el caso de las fiestas de renovación del centro ceremonial

.La imagen del santo cuya fiesta se celebra

.Invitados especiales, dos o más imágenes de santos y sus respectivas comitivas.

$\mathrm{Si}$ bien es un individuo el que aparece en las listas de espera como el responsable de celebrar la fiesta, su actuación depende de la participación de este grupo de personajes. Cada fiesta de mayordomia es una secuencia por si misma, puesto que cuenta con un principio y un fin bien definidos, que inicia con el recibimiento del cargo por parte del mayordomo y culmina con la entrega del mismo, un año después. Esta secuencia se integra por una serie de microsecuencias y se inserta en el contexto mayor del ciclo ceremonial anual.

En el momento de recibimiento de un cargo, se inicia la primera microsecuencia. En ésta se llevan a cabo: el recibimiento de la imagen en el santohkalli del nuevo mayordomo donde permanecerá durante un año, un banquete de 
bienvenida para los teachkame que colaborarán económicamente para la fiesta de la entrega del cargo, y una danza ceremonial que simboliza la inserción de esta fiesta dentro del ciclo general.

La petición para celebrar una fiesta de mayordomia, se realiza con varios años de anticipación. El Presidente Eclesiástico o Lector anota en una libreta la lista de peticiones para ser mayordomo de cada imagen. Algunas imágenes son más solicitadas que otras, especialmente en función de la jerarquia ya señalada en el capitulo anterior, en cuyo caso la solicitud debe aguardar su turno en la lista de espera. Dado que el sistema de cargos de Atlahuilco no constituye una escala ascendente, cualquiera que cuente con recursos y disponibilidad puede ser candidato a celebrar una fiesta, aunque sea una de las principales. Algunas imágenes del santoral son poco solicitadas, asi que un mismo mayordomo debe fungir como anfitrión de la fiesta dos o más años consecutivos, puesto que se considera inaceptable que se omita cualquier celebración. Una vez que se ha adquirido el compromiso como futuro mayordomo no existe la posibilidad de retractarse del mismo; se considera un agravio que puede acarrear una especie de sanción o castigo divino para el responsable o su familia.

Unos meses antes del recibimiento del cargo, el futuro mayordomo y su grupo doméstico se preparan acumulando los productos que serán consumidos, como maiz, azúcar, frijol, arroz y café, y adecuando el santohkalli, espacio donde se dará cabida a los invitados. Es necesario también ajustar la producción de maiz durante dos ciclos agricolas: el que antecede a la fiesta de recibimiento del cargo y el siguiente, es decir, el correspondiente a la fiesta de entrega del mismo. Se requiere, además, proveerse de ingresos monetarios extraordinarios, alargando los periodos de trabajo en las plantaciones o en la venta de productos forestales. En ocasiones, es necesario construir una habitación nueva para celebrar la fiesta, hecha de madera, con piso de tierra y tablones adosados a los muros a manera de bancos. Se realiza también entonces la invitación formal a quien fungirá como Tlayekanke acompañado por su esposa, a los Teachkameh y a uno o más Tlatekimaitl, si es el caso.

El protocolo de invitación consiste en una visita llevando obsequios. La cantidad de obsequios es coherente con la posición jerárquica de cada uno de estos personajes dentro de la estructura de la fiesta: al Tlayekanke se obsequia una bolsa de pan, una caja de cerveza, dos kilos de azúcar, un paquete de chocolate y una botella de licor; a quienes fungirán como Teachkameh se ofrece sólo un poco de pan y dos cervezas o refrescos, mientras que a los Tlatekimaitl se entregan los mismos productos que al primero pero en cantidades mayores.

b.1) Microsecuencia del recibimiento de la imagen.

Llegado el día del onomástico de una imagen, el mayordomo saliente culmina su año de ejercicio una vez que finaliza la ceremonia litúrgica y ofrece un bocado a 
los mayordomos de las distintas imágenes en el atrio del templo. Después desaparece de la escena pública, mientras el Presidente Eclesiástico o Lector hace entrega de la imagen y su "ornamenta" al nuevo mayordomo y su comitiva, quienes se encuentran reunidos en la Sacristia. En la casa de éste, desde hace dos dias se preparan para el recibimiento; se servirá café, arroz, frijoles y tortillas para los invitados. En esta microsecuencia juegan un papel fundamental las guirnaldas de flores, o xochikoskameh que en Atlahuilco se elaboran de margaritas blancas. El día anterior a este acontecimiento, un grupo de mujeres y niñas pasan varias horas ensartando las flores hasta formar docenas de xochikoskameh. El recibimiento del cargo consiste básicamente en colocar ritualmente collares de flores a la imagen que será la moradora del santohkalli por un año. Al igual que los humanos, los santos deben estar siempre acompañados, no sólo por sus protegidos, sino también por seres de su misma clase, otras imágenes de santos. Por ello en esta microsecuencia es fundamental la asistencia de un número variable de mayordomos que lleven a las imágenes de las cuales son anfitriones en el presente ciclo.

Desde el templo, se desplaza el nuevo mayordomo con la imagen recién recibida, acompañado de parte de sus Teachkameh, de su Tlayekanke y de las imágenes de los santos invitados, con sus respectivos mayordomos y comitivas. Al llegar a la casa, antes de transponer el umbral, se efectúa uno de los episodios más recurrentes en el sistema ritual de los nahuas: recibir a los recién llegados con humo de copal, guirnaldas de flores, pétalos de rosas de castilla y pequeños ramilletes de flores y hojas de naranjo llamados xochimanal. Después de haber atravesado por un ritual de pasaje, como un bautizo o una boda, el uso de flores y el humo de copal delimita ritualmente la entrada al santohkalli que es de este modo enmarcado como un espacio sacralizado.

Antes de entrar pues en este espacio, imágenes y personas son cuidadosamente sahumadas por el Tlayekanke y reciben xochimanalmeh mientras a las imágenes, (la festejada y sus acompañantes), se les colocan transversalmente dos xochicoscameh. El procedimiento es largo: dos personas sostienen los collares elaborados cuidadosamente el día anterior, ensartados en una vara de un metro de largo aproximadamente, asi como una canasta con pétalos de rosas, los cuales son esparcidas sobre cada una de las imágenes, mientras el Tlayekanke murmura algunas plegarias y sahuma y riega los pétalos de flores a cada imagen de la comitiva.

Cuando el grupo traspone por fin el umbral, se coloca a todas las imágenes en el altar, ya adornadas con las guirnaldas de margaritas, y se sirven los platillos mientras un trio de músicos de cuerdas, toca suavemente, colocado en un rincón de la habitación, a un lado del altar. Tocarán imperturbables durante varias horas. Después de comer, se ofrece cerveza y aguardiente de caña a los asistentes, quienes se animan a bailar para retirarse hasta que cae la noche. Al dia siguiente se realizará la parte más relevante de esta microsecuencia: el "baile 
del xochikoskat" o xochikoskaihtotia, ceremonia en la que se retirarán las guirnaldas a las imágenes. Desde mi punto de vista, esta ceremonia representa la afirmación simbólica de que ha finalizado el periodo liminal que constituye la etapa de transición de la imagen de un hogar a otro. La ceremonia también hace referencia simbólica a la continuidad del ciclo que ahora inicia y que se desarrollará el siguiente año, de manera similar, en otro santohkcalli.

Desde muy temprano las mujeres de la casa del nuevo mayordomo, preparan tortillas, café y frijoles para recibir a los participantes en la ceremonia. A media mañana llega la pareja de Tlayecankemeh. El santohcalli está limpio y ordenado después de los eventos del dia anterior. Mientras el Tlayecanque revisa que el espacio se encuentre en orden, y reaviva las brasas del sahumerio con copal, su mujer se encamina a la cocina. Se encuentran listos una serie de elementos que se utilizarán en la ceremonia: una canasta para colocar los xochicoscameh cuando sean retirados a las imágenes, por lo menos dos botellas con aguardiente que serán también indispensables, y suficiente copal. El Tlayecanque retira uno a uno los collares de flores ya marchitas que descansan sobre los hombros de las imágenes; las sahuma con copal y murmura plegarias inaudibles. Los anfitriones de la fiesta sostienen la canasta mientras él coloca los xochicoscameh en el interior de ésta, para ubicarla en el altar una vez terminada la tarea.

Comienzan a llegar los invitados cuando los músicos ya se encuentran en el interior del recinto, a un costado del altar, lugar que al parecer es su sitio habitual. En este episodio es central la presencia del mayordomo que recibirá el cargo al año siguiente. Aparece acompañado de una pequeña comitiva, quizás procedente de alguna localidad de la montana. Los Teachcameh del nuevo mayordomo empiezan a llegar y a acomodarse en los tablones que rodean el espacio del santohcalli. Todos traen una botella de aguardiente, que es una especie de requisito de entrada para este episodio ritual. El anfitrión y su Tlayecanque reciben cada una de las botellas, la besan y la colocan en el altar. Asi se acumulan por lo menos una veintena de ellas.

La música de cuerdas se escucha interminable mientras llegan más invitados; se sirve la comida ya pasado el mediodia. Inicia entonces la ceremonia en la cual se pondrá de manifiesto el sentido de diacronía de ésta como de todas las fiestas del calendario, en un recordatorio simbólico de que la fiesta en honor de esta imagen se repetirá de manera casi idéntica un año después. Colocados de frente al altar, el nuevo mayordomo y quien lo será al año entrante, intercambian dones iguales. Desde mi perspectiva este intercambio enfatiza el principio de igualdad entre uno y otro mayordomo, asi como el compromiso común de garantizar la continuidad y repetición del ciclo ceremonial.

El futuro mayordomo ofrece una caja de cerveza y una botella de aguardiente a su anfitrión. Este recibe los obsequios y entrega otros idénticos a su visitante. Se 
reparten inmediatamente entre los asistentes para regresar a los donadores los envases ya desprovistos de su contenido, con explicitas muestras de agradecimiento. Es entonces cuando comienza el baile. Se trata de que todos los asistentes se turnen, en grupos de tres, para bailar cuatro melodias con la canasta que contiene los xochicoscameh y una por una de todas las botellas de aguardiente que han sido acumuladas. Mientras uno sostiene la canasta, otro lleva el sahumerio con copal y otro más sostiene en sus hombros una caja de cerveza que provee el nuevo mayordomo entrante. Inician la danza los anfitriones, el mayordomo, su cónyuge y uno de sus hijos, continúan el futuro mayordomo y sus acompañantes y así pasarán por turno todos los asistentes, en un orden jerárquico que contempla la cercanía parental con los dueños de la casa. Cuando termina un turno se reparte el contenido de las botellas que acompañaron la danza y se reponen por otras llenas para que las sostenga el siguiente grupo.

Este procedimiento se repetirá con todas las botellas de aguardiente que fueron obsequiadas por los asistentes, procurando que todos participen. Quienes ya pasaron su turno continúan incorporados a la danza aunque ya con las manos vacias, de manera que poco a poco el Santohkalli se puebla de danzantes que se mueven cadenciosamente al ritmo de las cuerdas, animados por la cerveza y el aguardiente que debe ser consumido después de cada turno. El sahumerio despide incesante el aroma del copal que impregna copiosamente el recinto y la danza se vuelve un tanto embriagadora y monotona, puesto que pueden pasar varias horas hasta que todos los invitados cumplan con esta fase de la ceremonia, especialmente porque con el transcurrir de la tarde llegan más personas trayendo su botella de aguardiente que debe agregarse a su tiempo a la canasta.

Se trata pues de un espacio y un tiempo destinados especialmente a la libación y el baile. Se considera que es ésta una forma de manifestar "gusto", alegria que debe recibir la imagen festejada, quien no debe sentir que "no tenemos gusto por su fiesta". Después de varias horas de danza y consumo de alcohol, muchos hombres están totalmente embriagados y continúan bailando dando tumbos o bien se ubican en algún lugar de la habitación para no volver a levantarse. Las mujeres, generalmente más moderadas en este aspecto, tienen la opción de recibir la copa de aguardiente y verterla en un recipiente que han llevado para el caso, o bien agradecer el ofrecimiento y después untar el liquido sobre sus piernas, o verterlo directamente sobre el piso. La cuestión es no rechazar en ningún momento el liquido que ofrece el escanciador. Este es designado por el Tlayekanke de entre los asistentes y debe ofrecer la bebida, servida en un pequeño vaso de vidrio, hasta agotar el contenido de la botella que le fue asignada. Entonces el Tlayekanke toma una que se encuentre llena y elige a otra persona para que repita el escanciamiento.

El episodio del "baile del xochikoscate" termina cuando se han agotado las 
botellas de aguardiente que fueron obsequiadas al anfitrión de la fiesta. La música se escucha durante el resto de la tarde y parte de la noche. Los ejecutantes apenas descansan unos minutos para continuar imperturbables con su cometido alegrar el espacio ceremonial del Santohkalli. Paulatinamente la gente se retira a descansar; el futuro mayordomo que recibirá su cargo al año entrante y que será el anfitrión de este mismo episodio, se despide a una hora prudente para iniciar su recorrido de retorno.

Termina entonces el principal episodio de la microsecuencia de recibimiento de un cargo de mayordomia, el xochikoskaihtotia, mediante la cual quedó sellada la fase liminal, el rito de paso de las imágenes de uno a otro hogar. Al día siguiente, los mayordomos de las imágenes que fueron invitadas para acompañar a la festejada en esta ceremonia, regresan a la casa del nuevo mayordomo, acompañado de una pequeña comitiva para llevarse su imagen de regreso a su propio Santohkalli.

Una semana después, el nuevo mayordomo ofrece una comida exclusivamente para su círculo de Teachkameh, evento que constituye un protocolo de agradecimiento por haber aceptado colaborar con él para el banquete de entrega del cargo un año después. Desde el dia del recibimiento del cargo no cesa el movimiento en la cocina y el santohkalli. Al parecer los requerimientos de tortillas, café y algún otro alimento son constantes; la microsecuencia por fin termina siete dias después del recibimiento del cargo, con la comida para los Teachkame.

La microsecuencia de recibimiento de un cargo de mayordomo o mayordoma puede ser sintetizada de la siguiente manera:

\section{Domingo. (Dia 1)}

Recibimiento de la imagen en el Santohkalli del nuevo mayordomo. Colocación de xochikoskame a èsta y a las imágenes acompañantes y sus comitivas. Banquete y baile.

\section{Lunes (Dia 2)}

Baile del Xochikoscatl. Se retiran los collares de flores a las imágenes y se realiza un intercambio de dones entre el mayordomo entrante y el mayordomo que recibirá el cargo al siguiente año. Banquete para los asistentes: las comitivas de las imágenes acompañantes, los Teachkame, y el futuro mayordomo con su comitiva.

\section{Domingo (día 8)}

Banquete exclusivo para los Teachkame que colaborarán para la realización de la microsecuencia de entrega del cargo un año después. 


\section{b.2) La gestión anual del cargo.}

Después de realizada la microsecuencia de recibimiento del cargo, se considera formalmente iniciado el ciclo anual que cumplirá el mayordomo. En el transcurso de éste, será invitado a llevar a su imagen como acompañamiento en otras celebraciones de entrega y recibimiento de cargos. Durante este año la imagen del santo ocupará el lugar central del altar en su Santohkalli, y contará siempre con flores y un sahumerio con brazas de copal, disponible para que todo visitante la salude reverencialmente. Tarea importante durante su gestión anual será la de hacerse cargo cada domingo del doble de la imagen que se encuentra en el interior del templo, es decir, cambiar sus jarrones de flores y colocar nuevas veladoras. Esta actividad propicia las reuniones dominicales entre los mayordomos que cumplen su gestión en el ciclo actual. Se encuentran después de haber realizado sus tareas y en ocasiones toman ciertos acuerdos de interés común. Cuando se celebra una ceremonia de entrega de cargo durante la misa dominical, el mayordomo saliente les ofrece algunos alimentos que ha traido desde su casa, para finalizar el protocolo que establece el término de su gestión. Conviven entonces reunidos en el atrio.

Una responsabilidad del mayordomo es hacerse presente durante las fiestas de renovación del centro ceremonial. Como he mencionado, en estas fiestas todos los mayordomos que sostienen el ciclo actual se presentan en el atrio después de la misa, para ofrecer, apoyados por su grupo doméstico, atole, tamales de frijol, aguardiente y cerveza a su grupo de colaboradores. A través de estas comidas periódicas se refrenda el compromiso reciproco que han adquirido el mayordomo y cada uno de sus Teachkameh.

Es decir, mediante una serie de participaciones de diversa indole, se consigue que el ciclo anual de cada mayordomo no se restrinja a su actuación exclusivamente durante las microsecuencias de recibimiento y entrega del cargo. Sus participaciones en el curso de un año pueden sintetizarse de la siguiente manera:

-invitaciones para llevar a su imagen a otros hogares de mayordomos durante microsecuencias de recibimiento y entrega de cargos,

-invitaciones a las comidas ofrecidas en el atrio al final de la gestión anual de cada mayordomo,

-asistencia a las reuniones dominicales en el templo y el atrio,

-ofrecimiento de comida y bebida en el atrio del templo a su círculo de Teachkameh durante las fiestas de renovación del centro ceremonial.

La gestión anual como mayordomo permite entonces el acceso a una especie de 
hermandad temporal, conformada por elementos cambiantes, pero integrados en una organización estable y precisa. Este tipo de agrupación puede ajustarse a lo que Isidoro Moreno (1985, 36-37) llama "hermandades cerradas", las cuales se encuentran bien limitadas mediante un número de miembros o cofrades que no puede ser rebasado; su carácter es exclusivista y restrictivo, puesto que no es suficiente con poseer determinados requisitos, sino que es indispensable que exista un puesto desocupado y ser admitido en él.

\section{b.3) La microsecuencia de entrega del cargo.}

La entrega del cargo es la microsecuencia más relevante de la gestión anual de todo mayordomo. Culmina con su aparición formal en el ritual público que se lleva a cabo en el centro ceremonial: la misa, las procesiones y la posterior comida en el atrio que se ofrece a todos los mayordomos que no asistieron al banquete formal, la víspera de la entrega. La microsecuencia dura once dias. Inicia ocho dias antes de la aparición pública en el centro ceremonial, con la elaboración de los correspondientes xochikoskameh para el recibimiento de las imágenes invitadas para esta microsecuencia, y termina dos dias después del episodio público, cuando las mujeres se reúnen en la casa del mayordomo para lavar todos los utensilios utilizados y se ofrece una comida a las cocineras.

Desde el inicio de esta microsecuencia hasta la entrega del cargo al mayordomo entrante, los anfitriones de la fiesta guardan una serie de prescripciones rituales: vigilia, abstinencia sexual, no cambiarse de ropa y consumir aguardiente durante los brindis que continuamente se realizan en el curso de la fiesta. Se considera que si no se respetan estas restricciones, puede acontecer alguna desgracia para el mayordomo o sus familiares cercanos en un futuro inmediato. Hasta el dia de entrega del cargo, los anfitriones de la fiesta podrán descansar unas horas antes y bañarse y cambiarse de ropa, usando de preferencia prendas nuevas.

Como hemos visto, el recibimiento a las imágenes con collares de flores es un episodio recurrente en el sistema ritual de los nahuas. Estas llegan a la casa del mayordomo, traidas desde sus respectivos Santohkalli para iniciar la microsecuencia, una semana antes de la entrega formal del cargo. Se reúne un grupo de mujeres y algunas niñas, para hilvanar durante un dia entero las margaritas que formarán varias docenas de xochikoskameh, mientras otras preparan tortillas y frijoles suficientes para servir a la comitiva de las imágenes. Ambas tareas son dirigidas por la Tlayekanke. Generalmente es en los dias domingo cuando se realiza la misa de entrega de las imágenes, ya que es entonces cuando el sacerdote de la parroquia de Tequila visita los pueblos que corresponden a su jurisdicción. De modo que el domingo anterior a la ceremonia de entrega, cerca del mediodia, las imágenes invitadas llegan a la casa donde se realizará la fiesta y son recibidas en el umbral, donde se les sahúma y se les colocan los xochikoskame antes de ubicarlas en el altar, donde la imagen festejada ocupa el lugar central. Ha comenzado entonces formalmente la fiesta de 
entrega del cargo. Los invitados de este dia son exclusivamente los mayordomos de las imágenes que acompañarán a la imagen festejada durante toda esta microsecuencia (acompañados de un grupo de sus Teachkameh y sus Tlayecankemeh). Llegan los músicos y después de comer, se baila y se bebe hasta que cae la tarde.

Después de este evento que inaugura la fase de entrega del cargo, los tres dias siguientes se dedican a la preparación de los banquetes que iniciarán el viernes. El Tlayekanke y su compañera, asi como las mujeres invitadas como cocineras, permanecen desgranando maiz, tostando y moliendo café y preparando enseres y fogones para cocinar la res, ovejas o cerdos que se sacrificarán el jueves. Este dia, los hombres trabajan en la matanza y destazamiento del o los animales. Se preparan entonces las entrañas (visceras y otras partes) para servirlas en un caldo que se ofrece a los Teachkameh que empiezan a llegar para visitar a la imagen y entregar "la limosna" o cuota fija que les corresponde como cooperación. Mientras tanto, los Tlatekimaitl, o colaboradores especiales (quienes aportan la música, el castillo de pólvora y las flores) reciben en su casa a sus propios Teachkameh, éstos les entregan a su vez su "limosna", y se les ofrece una comida sencilla.

El viernes es el gran dia, se sirve entonces el resto del animal, y tamales de maiz agrio llamados xokotamales. Este es el evento más sobresaliente desarrollado en el Santohkalli durante toda la secuencia de la gestión del cargo, ya que se sirve carne roja, platillo que los nahuas consumen exclusivamente durante las fiestas de mayordomia. Se considera que los Teachkame que cooperaron económicamente para la compra del animal, son los invitados especiales de este dia. Van llegando formalmente, generalmente marido y mujer o algún otro familiar cercano, y después del obligado saludo a las imágenes del altar, se dirigen a la mesa que ha sido colocada en el Santohkalli y son atendidos de inmediato. Se coloca en la mesa una canasta con "pocillos" o tazas y una jarra de café, elementos que forman parte del protocolo de los banquetes. Despúes se ofrece cerveza, un caldo con carne, xokotamales y tortillas. Además, se les entrega un plato repleto con trozos de carne que se llevarán a sus casas. Previamente, se distribuyeron equitativamente las porciones que se entregarian a cada uno de los colaboradores.

Aparentemente se debe satisfacer su expectativa de recibir la cantidad adecuada del alimento en retribución al monto de su cooperación, tanto para consumir ahi mismo, como para llevar a casa y disfrutar del platillo durante varios dias. El ingreso económico que el mayordomo obtiene a partir de las cooperaciones de su circulo de colaboradores está calculado para que sea el necesario para adquirir el o los animales sacrificados. Si se desea comprar una res, por ejemplo, se invita a muchos colaboradores, unos cincuenta o sesenta, entre los cuales se divide el costo del animal, de modo que cada uno aporte una cantidad considerable pero no exhorbitante (entre cien y docientos pesos). En las fiestas menores la comida 
es más sencilla y puede ser suficiente con unos veinte colaboradores que aporten una cuota más baja, por ejemplo cincuenta pesos. Su papel como mayordomo le dará derecho, en el curso de un año, a asistir a otros banquetes llevando a su imagen como invitada, o departiendo en el atrio después de otras fiestas de mayordomia. Si bien el gasto de los anfitriones de las fiestas se reparte entre sus Teachkameh y sus Tlatekimatil, se requiere la adquisición de considerables cantidades de otros productos: maiz, café, arroz, leña, azúcar, frijol, chile, jitomate, aguardiente y cerveza que corren a cargo del mayordomo y su grupo doméstico desde el inicio de su gestión.

En la cocina, un grupo de mujeres continúa haciendo tortillas, otras preparan los xokotamales, una o dos ancianas se ocupan de mecer improvisadas hamacas donde duermen los bebés de las cocineras y un nutrido grupo de niños corre alrededor de la casa. El anfitrión y dos o tres hombres allegados a él cortan los trozos de carne ya cocidos para ofrecer a los visitantes, mientras la Tlayecanke sirve las raciones a los recién llegados. Es al atardecer cuando llega una mayor concurrencia. Algunos comen de pie, ubicados en cualquier parte de la casa. Llega gente de distintos puntos del municipio. Dado que predomina una tendencia hacia la endogamia municipal, en estas ocasiones los familiares que radican en otras rancherias o parajes forman parte de los invitados, aunque sea sólo para asistir en este dia; no se presentan personas procedentes de localidades ajenas al municipio. También puede ser que alguno de los Tlatekimaitl sea residente de fuera de la cabecera con lo que la fiesta se ramifica hacia su hogar, donde atiende a sus propios Teachkameh, o los músicos pasan las dos noches previas a la entrega del cargo. Durante toda la jornada los músicos de cuerdas tocan sones tradicionales y en ocasiones aparece también la banda de viento. La gente come, baila y bebe hasta bien entrada la noche.

El sábado, dia de "las visperas", desde antes de que amanezca, la banda de música, los danzantes y los cohetes de pólvora señalan que se están llevando a cabo las mañanitas en el interior del templo. Hacia el mediodia de nuevo se reúne una gran cantidad de comensales en la casa del mayordomo. Ya se ha cumplido el compromiso de repartir a los Teachkameh del anfitrión sus porciones correspondientes y de hacerles los honores la noche anterior. Ahora es el turno de atender a los Tlatekimaitl con sus respectivos circulos de colaboradores. Es la hora de invitar también a los danzantes y músicos a ocupar formalmente un lugar en la mesa.

El protocolo consiste en invitar a pasar a la mesa, por turnos, a cada Tlatekimaitl; quien a su vez invita a sus propios colaboradores. El anfitrión entrega a este funcionario una caja de cervezas para que las reparta entre todos, un platón con xokotamales para que haga lo propio, mientras se les reparten platos con carne. A estos grupos sólo se les ofrece lo que comerán ahi mismo. Esta comida dura toda la tarde mientras pasan todos los grupos a la mesa y los danzantes y músicos continúan con sus ejecuciones, siendo los últimos en 
probar los alimentos. Después comienza el baile en el interior del Santohcalli. Se baila en parejas mixtas o en parejas de hombres o en parejas de mujeres. Si se trata de una de las fiestas principales, por la noche habrá una misa en el centro ceremonial adonde se llevarán las imágenes en procesión, antecedidas por danzantes y músicos. Regresará de nuevo la imagen a la casa para salir definitivamente al dia siguiente.

El anfitrión y sus allegados lucen agotados después de haber pasado varios días en los preparativos y atención a los invitados, bebiendo y sin dormir, puesto que se prescribe la vigilia y la abstinencia sexual durante este periodo final de su gestión como mayordomo. El consumo de alcohol es también una prescripción ritual, casi obligatoria. La noche de la vispera después de haber cumplido ya con los compromisos de atender a los invitados durante una semana casi continua, los anfitriones de la fiesta pueden por fin dormir; al dia siguiente, el domingo, será la culminación del final de su gestión.

El domingo muy temprano, los cohetes de pólvora anuncian desde la casa del mayordomo que la fiesta continúa. Es común escuchar estallidos de cohetes desde distintos puntos del pueblo, puesto que mientras en un hogar se lleva a cabo una microsecuencia de una mayordomia determinada, en otro se efectúa otra (como otros pueblos indigenas, los nahuas son grandes consumidores de pólvora y de flores, imprescindibles marcadores del espacio y tiempo rituales). Por la mañana, llegan a la casa del mayordomo las comitivas de las imágenes invitadas, las cuales se llevarán en procesión acompañando a la imagen anfitriona, camino al templo, donde por fin ésta pasará a otras manos y a otro Santohkalli.

Se sirve un almuerzo para mayordomos acompañantes y sus comitivas. Ellos y los familiares del mayordomo, el Tlayecanke y las mujeres que aún ayudan en la cocina, conforman la procesión que despide a la imagen después de un año de mantenerla en el altar doméstico. Después del almuerzo, antes de salir de la casa, se baila por última vez ante la imagen durante breves minutos, al ritmo de suaves melodías del violin y la guitarra. La procesión se encamina al templo pero nadie más se une a ella a pesar de que es domingo y la gente se dirige también hacia el centro ceremonial; ni siquiera los Teachkameh en conjunto aparecen para acompañar el recorrido desde la casa del anfitrión hasta el templo. Si se trata de una de las fiestas de renovación del centro ceremonial, acudirá a la misa gente de los distintos parajes y rancherias, si no es asî, la gente de la cabecera y la comitiva del mayordomo entrante que puede ser de otra localidad, son los asistentes a la misa y a la procesión que se llevará a cabo después de ella. Más tarde, en el atrio, los anfitriones de la fiesta, esperan con canastas de tamales de frijol y atole de maiz para convidar a los mayordomos del resto de las imágenes que se festejan en el ciclo anual.

Pero aún no terminan las actividades del mayordomo saliente, aunque asi sucede 
en apariencia, cuando después de entregar la imagen y la parafernalia ritual al mayordomo entrante se retira a casa, acompañado sólo de sus familiares cercanos, ya con las manos vacias. El lunes se servirá otra comida, especial para los Tlatekimaith, y el martes, por fin, se concluye invitando a comer a las cocineras que ayudaron durante todos estos dias de trabajo. Se cierra asi el ciclo anual de cada una de las imágenes que componen el calendario ritual de los nahuas. Antes de entrar en otro Santohkalli, toda imagen deberá pasar por un periodo de liminalidad que terminará con el baile del xochikoskatl o xochikoskaitohtia.

\section{Microsecuencia de la Entrega de un Cargo de Mayordomo o Mayordoma. Espacio doméstico del mayordomo saliente:}

\section{Domingo (dia 1).}

Recibimiento de las imágenes de los santos invitados para esta microsecuencia. Banquete para sus respectivos mayordomos y sus acompañantes.

Lunes, martes y miércoles (dias, 2, 3 y 4).

Adquisición de enseres y adecuación de espacios para la preparación de grandes cantidades de alimentos. Destazamiento del o los animales y preparación de la carne y de tortillas.

\section{Jueves (dia 5)}

Visita del circulo de Teachkameh para entregar la "limosna". Se les sirve una comida a base de visceras y entrañas.

En la casa de cada Tlatekimaitl se ofrece una comida a sus respectivos circulos de Teachkameh.

\section{Viernes (dia 6)}

Banquete exclusivo para los Teachkameh donde se les sirven sus porciones de carne. Baile.

\section{Sábado (día 7)}

Celebración de "visperas"

Banquete exclusivo para los Tlatekimaitl y sus círculos de Teachkameh, así como para los danzantes y músicos. Baile.

\section{Domingo (dia 8)}

Desayuno para los mayordomos y comitivas de las imágenes acompañantes. Entrega de la imagen en el templo.

\section{Lunes (dia 9)}

Comida exclusiva para los Tlatekimaith, en agradecimiento por su colaboración. 


\section{Martes (dia 10)}

Comida exclusiva para las cocineras que colaboraron en las tareas domésticas durante toda la microsecuencia.

\section{c) Reflexiones en torno a la circulación de imágenes, comitivas y bienes: un circuito múltiple de reciprocidades.}

Como hemos visto, en Atlahuilco el desarrollo del ciclo ritual anual implica una continuada sucesión de cuarenta y dos ciclos individuales, cada uno de los cuales puede ser considerado una secuencia por si mismo. Esta secuencia ritual, se compone de distintas fases altamente codificadas. La invitación y recepción de santos invitados por parte de los anfitriones de las fiestas es una parte medular en el desarrollo de las mismas. Se trata, desde mi punto de vista, de un mecanismo de integración entre el grupo de mayordomos responsables de sostener el ciclo anual. Al mismo tiempo, representa una forma de apropiación y sacralización del espacio transitado llevando las imágenes objeto de culto. Por otra parte, la movilización de las imágenes de los santos sintetiza la concepción del ser social de los nahuas; se trata de una metáfora de las relaciones humanas, en las cuales las personas sueles ser representadas por otras, asi como acompañadas y recibidas con humo de copal y collares de flores después de haber atravesado una fase liminal. La compañia de visita es una asociación de culto de corta duración, llevada a cabo expresamente como vinculo para entregar una imagen de un mayordomo a otro.

Los mayordomos y las comitivas de los santos visitantes a las casas donde se desarrollan las fiestas son los únicos invitados de honor que no cooperan materialmente de ninguna forma para la celebración. $\mathrm{El}$ intercambio de santos a lo largo del año y a lo largo y ancho del municipio, refleja las relaciones diplomáticas estables entre ciertos grupos domésticos involucrados, dado que es imperativo seleccionar sólo a cierto número de imágenes, dependiendo de la capacidad del anfitrión para atender a sus comitivas. Si las relaciones son tensas con alguno de los mayordomos o sus parientes más próximos siempre se cuenta con la posibilidad de elegir a otros. El intercambio de imágenes indica pues el grado de interdependencia entre los grupos familiares involucrados, asi como la situación diplomática entre quienes fungen como anfitriones de las fiestas en el presente ciclo anual. Al mismo tiempo, refleja las relaciones diádicas entre las localidades que integran el territorio municipal.

Asi como el intercambio de imágenes de corta duración propicia un cierto tipo de relaciones de reciprocidad, en las cuales el requisito es devolver la invitación en el momento oportuno, seria imposible solventar las fiestas de mayordomía en un contexto de tan aguda escasez como lo es la sierra de Zongolica, sin contar con la colaboración valiosa de un organizado grupo de personas. Esta dinámica permite el establecimiento de compromisos interpersonales en los cuales cada 
participante lleva la cuenta rigurosa de lo que ha invertido en colaborar para el desarrollo de alguna fiesta donde él no funge como anfitrión y de lo que debe recibir a su cuenta por dicho concepto. Este sistema de préstamos a largo plazo, permite a los individuos planear sus compromisos con anticipación y arriesgarse a solicitar un cargo sabiendo que ha invertido en las fiestas de otros y que éstos le devolverán el préstamo en su momento. De modo que antes de solicitar un cargo, el futuro anfitrión de la fiesta hace un cálculo exacto de lo que le deben en especie, no en dinero- por haber colaborado años atrás con una banda de música o una dotación de cerveza para otra fiesta. Al mismo tiempo considera las posibilidades de endeudarse en caso de no contar con los recursos necesarios para solventar todos los gastos.

La estrategia de pedir y devolver en especie, es una solución ante las dificultades que implicaria llevar las cuentas en un sistema de préstamos en efectivo a largo plazo, en el cual habria que considerar las fluctuaciones de la moneda. De este modo, se devuelve exactamente lo que se recibió: determinadas horas de música, o cierto numero de cohetes o de ramos de flores. Es deseable, sin embargo, no endeudarse demasiado, puesto que ello se convierte en un factor condicionante para asumir otro compromiso, no sólo relativo a las fiestas de mayordomia, sino también al ciclo de vida individual como bodas o bautizos.

Durante las fiestas se lleva a cabo también el intercambio reciproco de fuerza de trabajo. Un grupo de hombres y mujeres, casi siempre parejas de cónyuges, son invitados especialmente para colaborar en las labores en la cocina y en el acarreo de leña, agua y todo lo necesario para los banquetes. Por otra parte, como he relatado, existe un grupo de invitados especiales que reciben los honores durante el banquete de la vispera de entrega del cargo, los Teachkameh, quienes hacen posible la adquisición de un bien de consumo escaso y ocasional para los habitantes de la sierra de Zongolica, la carne de res, de cerdo o de borrego ${ }^{1}$, alimento que se prepara solamente en contextos rituales.

Este sistema de cooperaciones, visitas e intercambios reciprocos, posibilita que los participantes tengan oportunidad de asistir a un número considerable de banquetes a lo largo del año. Propicia una distribución horizontal de los recursos entre las redes de colaboradores que se entrecruzan en distintos momentos, asi como una disposición de comida y bebida a la que no se accederia en el seno de los hogares individuales.

El procedimiento mediante el cual un mayordomo entrante se dirije a quienes desea que integren su grupo de Teachkameh y cooperen económicamente con una cuota fija para el banquete de entrega del cargo, permite a éstos prepararse

\footnotetext{
El consumo de carne de aves de corral se lleva a cabo también escasamente, pero se recomienda en casos de enfermedad o convalecencia; o bien en ocasión de recibir alguna visita o para festejar el regreso de quienes permanecieron fuera una temporada por motivos de trabajo en las plantaciones.
} 
económicamente con anticipación para disponer del dinero en efectivo un año después. Este tipo de acuerdos a largo plazo resulta ser una estrategia viable para un tipo de sociedad que requiere de movilizarse continuamente fuera de su entorno más inmediato. Los compromisos adquiridos con anticipación permiten programar las fechas de retorno a la comunidad y establecer las necesidades económicas que habrá que cubrir. El ciclo ceremonial propicia de este modo una especie de regreso escalonado de los migrantes y al mismo tiempo su aparición simultánea durante las fiestas de renovación del centro ceremonial.

De este modo, la participación en las fiestas de mayordomía muestra la red de pertenencias sociales $y$ de relaciones jerárquicas. Las fiestas pueden interpretarse como un reflejo de la estratificación social existente, puesto que para participar en éstas es necesario contar con los recursos minimos indispensables para fungir como invitado, ya sea cooperando económicamente, en especie, con trabajo o con imágenes de santos. La fiesta de mayordomía es pues un ámbito de participación restringido, del cual se autoexcluyen, determinados sectores de población, como ciertas familias mestizas, jóvenes y adultos indigenas que cuestionan el ritualismo, el dispendio y el consumo de alcohol, influidos por la educación escolarizada, asi como por las labores de catequistas y párrocos, y los conversos a denominaciones religiosas distintas.

Como se señalaba páginas atrás, la realización de la secuencia de cada fiesta de mayordomia propicia que habitantes de distintas localidades del municipio se interrelacionen de forma más o menos continua a largo del ciclo anual. Cada fiesta es un medio dinámico que promueve la circulación y el intercambio de bienes de consumo, de dinero y de fuerza de trabajo, asi mismo, provee de un espacio y un tiempo destinados a la danza, la libación y el goce. En cada microsecuencia, los banquetes enfatizan la distribución equitativa del alimento y la bebida. El movimiento ritmico, continuo y uniforme de la danza que se prolonga durante varias horas en los tiempos y espacios establecidos, es expresión de un estado en que la conciencia de cada uno es acaparada por un sentimiento y una meta comunes; el argumento del trance o esa voluntad común tiende a la disolución de los papeles sociales, desemboca en la desaparición momentánea de la vida social organizada. La fiesta engendra la capacidad de cambiar el mundo mediante un ejercicio en el que el organismo individual se funde en el organismo colectivo. (Duvignaud, 1997: 31: 222-223).

Al analizar lo que llama "derroche institucionalizado" en las fiestas de mayordomias, Aguirre Beltrán apunta que los dos rasgos fundamentales de este complejo cultural son el gasto excesivo y la bebida ceremonial. Desde su punto de vista, ambos rasgos permiten vislumbrar "un caso acabado de conversión polar en la práctica religiosa...donde los dioses muertos del panteón mesoamericano renacen en el culto a los santos de la hagiografía católica" $(1986,146)$. El autor recurre a las crónicas de Motolinia para argumentar que el derroche institucionalizado de bienes, comida y bebida en sociedad mexica eran pautas de 
conducta aprobadas por la sociedad para conseguir honra y poder. Durante el periodo colonial temprano, la fiesta colaboró en la creación de una organización social menos señorial, mediante el sistema de escala que distribuye responsabilidades y derechos y regula reciprocidades. Aguirre Beltrán considera además a la fiesta como dispensadora de identidad, inyecta fuerza y vigor a la comunidad india:

"sin la fiesta, los indios que sobrevivieron a la invasión y establecimiento de una colonia de explotación no hubieran podido recrear su cultura y sin la fiesta, los indios de hoy dificilmente podrán sostenerse frente al cerco que le tiene tendido el capitalismo industrial y sus atractivos" (op.cit.: 160-161).

Las redes de relaciones sociales activadas en estos espacios festivos, se encuentran enmarcadas por una tendencia hacia la endogamia en la escala municipal. Considerando que otra tendencia es la residencialidad en el espacio virilocal, el modelo de participación en toda secuencia de mayordomia permite el enlazamiento de habitantes de distintos puntos de procedencia desde el interior del espacio municipal. Además, en este modelo de relaciones se involucra durante la microsecuencia de recibimiento del cargo- la participación del mayordomo que tomará el cargo un año después. Por lo tanto, la dinámica propuesta por la rotación de los cargos propicia las relaciones entre habitantes de distintas localidades participantes, como ejemplifico a continuación:

Lugar de residencia de un mayordomo y su grupo doméstico: Zacamilola Lugar de origen de la esposa del mayordomo: Atetekoxko

Lugar de procedencia del mayordomo que recibirá el cargo el siguiente año: Atlehuaya.

Lugares de procedencia del círculo de Teachkameh compuestos por el circuito de parientes y vecinos de ambos cónyuges: Zacamilola y Atetekochko.

También participarán -en su caso- las familias politicas de las hijas que se han unido en matrimonio con hombres de otra localidad, Cuauhtlamanca, por ejemplo. De modo que estos espacios se convierten también en escenarios para la concertación de alianzas matrimoniales y convenios contractuales de diversa indole. En el ciclo siguiente, la pareja de mayordomos, residente de Atlehuaya, por ejemplo, será anfitriona de personas de las localidades respectivas a sus redes parentales y por supuesto del mayordomo y comitiva que recibirá el mismo cargo al siguiente año.

Este modelo de relaciones intracomunitarias se repite en las cuarenta y dos fiestas del ciclo anual, promoviendo una movilidad continua, hilvanando el mismo número de ciclos en un solo ciclo paradigmático. El esquema de interrelaciones se encadena en sentido diacrónico, en la sucesión de cada fiesta y en la repetición del calendario año tras año.

En el nivel sincrónico, el modelo se traslapa durante el desarrollo de cada una de 
las cuarenta y dos secuencias, en un sentido dinámico y multidireccional, permitiendo etapas de simultaneidad durante los periodos sucesivos de encadenamiento entre una y otra fiesta. Tal pareciera, como señala Duverger (1983: 73-93) para la sociedad mexica, que se trata de evitar que un número significativo de personas quede fuera del circuito de los comportamientos económicos. La gestión de la fiesta, al igual que en la sociedad azteca, responde a una exigencia cósmica.

Este sistema se expresa pues en un engranaje que promueve la movilización de distintas capas de población, como si se persiguiera el cumplimiento de un intenso compromiso religioso adquirido irremisiblemente hacia el conjunto de las imágenes que conforman el panteón local. Al mismo tiempo, conlleva un importante papel como mecanismo de confirmación de la pertenencia a un circulo parental y residencial, pero enfatizando de forma continua el lazo con los pobladores de las distintas localidades del ámbito municipal. Pareciera responder a esta necesidad la intensa movilización de un punto a otro, llevando imágenes de santos y asistiendo a las fiestas, dentro de un ámbito de pertenencia común, el territorio, como si se constatara de este modo la permanente conexión entre la vida y el espacio.

Por otra parte, este esquema de la rotación de cargos cuenta con los recursos figurativos para representar tanto su desarrollo diacrónico a lo largo de un año solar y en una sucesión circular anual, como su sentido de sincronia, es decir el que se refiere a la expresión de que todas las fiestas del calendario forman parte de un solo ciclo y de un mismo sistema. Los convites en el atrio que se llevan a efecto después de cada entrega de un cargo expresan el sentido sincrónico del sistema, especialmente en aquellos realizados durante las fiestas de renovación del centro ceremonial.

Estos convites pueden interpretarse ceremonias comunicativas que expresan por lo menos dos mensajes fundamentales:

i) Durante las fiestas menores, después de entregar el cargo, se ofrecen alimentos en el atrio al resto de los mayordomos que actualmente colaboran en el sostenimiento del ciclo ritual. Es decir, se expresa el sentido sincrónico de la fiesta en el contexto temporal anual y la inserción de cada mayordomo en un solo conjunto.

ii) Durante las fiestas de renovación del centro ceremonial, todos los mayordomos deben ofrecer simultáneamente una comida en el atrio a su círculo de colaboradores, de manera que en este episodio participan todos los funcionarios que en el presente ciclo sostienen el calendario festivo.

De manera que estos convites comunican, por una parte, el sentido de sincronia del sistema de rotación de cargos, y por otra, la jerarquia de las fiestas del 
De manera que estos convites comunican, por una parte, el sentido de sincronia del sistema de rotación de cargos, y por otra, la jerarquia de las fiestas del calendario y su naturaleza como marcadores de tiempo, es decir, se trata expresiones metonimicas del sistema (Leach, 1978: 21).

La movilización de las imágenes de los santos, asistiendo en calidad de acompañantes en las fiestas particulares, expresa también el sentido de sincronia, al recordar que son un conjunto de personajes, actores sociales e imágenes de santos, quienes colaboran en la gestion sagrada de esta temporalidad cíclica.

El sentido diacrónico, por lo tanto, se expresa en la sucesión de cada una de las festividades mediante la celebración de su fase pública en el centro ceremonial al final de su ciclo, cuando se da por concluida la labor en la gestión del cargo y se cumple con una fecha del calendario. Este sentido se expresa también en la ceremonia del baile del xochikoskatl, en la microsecuencia de recibimiento del cargo, cuando aparece en escena el mayordomo que recibirá hasta el año siguiente, como tratando de enfatizar el compromiso de dar continuidad en el tiempo a la gestión sagrada en torno a cada imagen en particular, pero dando cuerpo a la sucesión calendárica del conjunto de fiestas.

Por otra parte, como hemos visto en la descripción de la secuencia de la fiesta de mayordomia, al pasar de un Santohkalli a otro, toda imagen atraviesa por un periodo de liminalidad que finaliza con el recibimiento en el umbral de la casa de los nuevos anfitriones, y concluye con el "baile del xochikoskat?", cuando se retiran los xochicoskameh de recibimiento.

Este periodo de liminalidad inicia durante la fase pública de entrega de un cargo, es decir, desde el momento en que la imagen abandona el Santohkalli donde se mantuvo durante un año, para trasladarse a otro hogar después de haber pasado por el centro ceremonial. Se atraviesa entonces el circuito ceremonial del espacio ritual público para llegar de nuevo a otro escenario doméstico, manifestando de ese modo la trascendencia de la celebración para la colectividad, así como la transición entre la fase pública y la fase privada de la fiesta. Se recuerda entonces la pertenencia a un espacio social que va más allá de los escenarios domésticos, espario de este modo aprehendido y sacralizado. El ciclo ritual reduce la ambigüedad debido a su calidad repetitiva, rica en signos visuales que transmiten información tanto a participantes como a espectadores (Leach, op. cit.: 56).

Hasta aqui he presentado el modelo ideal del funcionamiento del sistema de rotación de las imágenes de los santos que integran el ciclo festivo de Atlahuilco, no obstante, debe considerarse que la reproducción de este sistema no implica una ausencia de contradicciones en su seno, sino una forma de regulación de dichas contradicciones dirigida al mantenimiento provisional de su unidad 
(Godelier, 1998: 89).

\section{d) Agrupaciones residenciales y participación ceremonial.}

Según mi interpretación, en Atlahuilco el ciclo festivo implementado a través del sistema de cargos, se consolidó como una de las formas de organizar las relaciones entre las distintas instancias de la comunidad municipal, desde las unidades domésticas, los parajes, las rancherías, hasta el nivel central de la cabecera. La iglesia principal se constituyó en el signo más evidente del ordenamiento espacial; permitió la ubicación de un centro en un conjunto de localidades que respondian a una estructura más bien difusa. De este modo, la identificación colectiva se dio en torno a dos elementos que demostraron una notable potencialidad como marcos simbólicos de referencia: el templo y la imagen de San Martin, el santo patrono (Rodriguez, 1995b).

El desarrollo del ciclo ritual propicia que los habitantes de las distintas localidades del municipio se interrelacionen continuamente. A través de una serie de encadenamientos resultantes del desempeño ceremonial, se fomentan las relaciones entre habitantes de diferentes puntos del municipio. Estos mecanismos tienen incidencia también en la implementación de estrategias muy claras en torno a las alianzas matrimoniales. Dado que existe esta fragmentación del espacio municipal, el ciclo ritual está dirigido tanto a enfatizar las diferencias como a reafirmar la unidad. La celebración del ciclo festivo ha constituido una forma de organizar la institucionalización de formas de intercambio intersectorial, desarrolladas a nivel de organización comunal.

La pluralidad de asentamientos se involucra en un movimiento incluyente, participando en el sistema ceremonial y administrativo global. La manifestación más explícita de esta vinculación se evidencia en las ceremonias de renovación del centro ceremonial. En Atlahuilco estas ceremonias se celebran, como ya dijimos en cuatro momentos especificos a los largo del año: durante la Semana Santa, en la fiesta de Corpus Christi, en la fiesta de San Martin, santo patrono del municipio y en las fiestas de fin de año.

La filiación local del conjunto de asentamientos del municipio, está ligada en gran medida, aunque no exclusivamente, al principio de participación en los asuntos relativos al sostenimiento del ciclo ritual. Sus habitantes se involucran en una red social, a través de nexos normativos y marcos simbólicos de referencia, cristalizados a través de las celebraciones religiosas. Es posible afirmar, en consecuencia, que el pueblo -en el sentido émico- puede ser entendido como una instancia organizativa donde los distintos asentamientos y agrupaciones residenciales participan en un juego de relaciones que sostienen y propician los vinculos intersectoriales. Cada uno de los segmentos cuenta con sus especialistas rituales -Tlayecankemeh- los responsables de dirigir la participación de los habitantes de su segmento en las ceremonias relativas al 
sistema de cargos religiosos y al ciclo de vida individual, asi como con sus siwatlake, los pedidores de mujeres.

Las alianzas matrimoniales entre las diferentes agrupaciones, constituyen un hilo fundamental dentro de la red social que sostiene los lazos entre ellas. De acuerdo a un muestreo realizado en la localidad con la finalidad de establecer las tendencias en relación a los patrones de residencia, fue posible detectar que se manifiesta la propensión hacia la endogamia a nivel del municipio. Si bien el centro de la cabecera municipal, en las familias mestizas se detectó la presencia de mujeres provenientes de fuera del municipio, e incluso de fuera de la región, en el resto de los grupos domésticos encuestados, las mujeres -respondiendo también mayoritariamente a un tipo de residencia virilocal- proceden de cualquier otra de las localidades del entorno municipal (Rodriguez, 1993: 63-87).

Por lo tanto, mi interpretación en este sentido es que en Atlahuilco se impuso como un mecanismo más de identificación, un sistema de matrimonios exogámicos entre las distintas unidades socioterritoriales que quedaron incluidas en una sola unidad política, favoreciendo la endogamia dentro de los limites municipales. Al mismo tiempo, el sistema de intercambios y de patrocinio de cada una de las fiestas del ciclo ritual anual, contribuyó a constituir los mecanismos integradores que operaron para articular a todas las instancias del territorio, desde las unidades domésticas hasta el nivel más inclusivo representado por los limites municipales. La rotación de los cargos religiosos proporciona espacios para conciliar posibles conflictos $y$ fricciones entre facciones o agrupaciones residenciales, mientras que se ejerce cierto control sobre el acceso a los recursos materiales y sociales mediante el ejercicio de relaciones de reciprocidad e intercambio, propiciando los espacios y las vias para compartir momentos festivos $\mathrm{y}$ formas de intercambiar dinero $\mathrm{y}$ bienes de consumo.

Estos mecanismos inclusivos y abarcativos de los distintos agregados sociales ubicados dentro de los limites del municipio, permiten la actualización de la pertenencia y la identidad locales, como señala un habitante de Tepexititla: "San Martin Atlahuilco es mi pueblo, aqui es rancheria pero yo pertenezco a San Martín".

El desarrollo de cada secuencia ceremonial del calendario requiere el manejo de un sistema de simbolos públicos dentro de un contexto ritual, mismo que es demarcado mediante la rotación de las imágenes de los santos de uno a otro punto del municipio. El movimiento de las imágenes de los santos representa la apropiación y sacralización del espacio, implica una serie de actos rituales y secuencias ceremoniales de gran significado: se transporta cada imagen del templo a la casa del responsable del festejo donde se le rinden ofrendas, oraciones, banquetes y danzas durante varios dias para regresar después la imagen al templo. De ahi será transportada a otro hogar, donde permanecerá por el periodo de un año y se realizará el mismo ceremonial antes de retornarla de 
nuevo al templo.

Se honra pues a los santos a base de trasladarlos en el espacio, en procesiones y rotaciones entre los habitantes del entorno comunitario. De este modo, la imagen sagrada toma posesión de los puntos que visita; la capacidad de lograr atravesar el territorio reafirma la conexión vital entre la vida y el espacio (Grimes, 1981). Este movimiento ritual sacraliza el territorio común y lo estructura jerárquicamente, mediante desplazamientos que van del centro -el templo ubicado en el pueblo cabecera-, hacia los limites -los hogares de las rancherias y parajes- subrayando el interés compartido, la unidad y al mismo tiempo, las divisiones grupales. Las secuencias rituales proporcionan también las vias para enfatizar la microlocalidad: cuando los habitantes de un paraje se hacen cargo de realizar la fiesta dirigida a alguna de las imágenes del calendario, sólo ellos y sus invitados exclusivos de otros puntos del municipio, participan en los banquetes y bailes ceremoniales que se desarrollan en su hogar, antes de retornar la imagen al templo, donde la participación será ya colectiva.

La celebración de la fiesta pública al final del ciclo que acompaña el retorno de cada imagen al templo principal para ser llevada de ahí a otro hogar, representa lo que Grimes considera la naturaleza publica y civica de los rituales: un acto simbólico compartido, un acto sancionador que está en el centro del sistema de culto a las imágenes de los santos y es al mismo tiempo la ocasión de expresar el ethnos, la tradición local. En la fiesta pública con la que culmina la gestión de todo cargo religioso, se salva la brecha que separa la observancia religiosa de la civica, se convierte en un ritual que promueve simbolos destinados a generar cooperación y respeto mutuos (Grimes, op. cit.: 36). La fiesta desemboca en un proceso dramático, en la medida en que consta de un nivel de representación en el cual las relaciones entre las distintas agrupaciones residenciales se ponen de manifiesto en un espacio de comunión. Es decir, la fiesta expresa una sintesis de la vida social en la que existen diferencias de estatus, de poder, de filiación; a través de ella se vinculan estructuras étnicas, civiles y religiosas (Grimes, ibid.).

En Atlahuilco, por tanto, la gestión del territorio se ha cristalizado en gran medida mediante el ciclo de fiestas. A partir de su implementacón se sostiene un movimiento simbólico de jerarquias, del centro hacia las fronteras de un espacio claramente demarcado. La reciprocidad y la redistribución han operado como principios generales, que ligan a los grupos sociales y politicos y ordenan las relaciones entre el hombre y las divinidades y entre los hombres entre si. Este tipo de organización propicia una especie de conmutaciones gramaticales, las cuales proporcionan el sentido del carácter intercambiable de las posiciones de cada grupo doméstico y cada segmento o sector dentro del conjunto.

Pero también en el nivel de los segmentos se produce una modalidad de identificación que obedece al imperativo de enfatizar un nivel más localizado, una microidentidad que subyace en aquella más abarcativa que se refiere al 
municipio, el territorio bajo tutela del santo patrono. Se implementan mecanismos de afirmación de este nivel de identificación: matices particulares en los procedimientos rituales, en el atuendo e indumentaria, y en fin, en las formas de interrelación con el resto de los segmentos

Un análisis más detallado mostraria que también en las facciones, -es decir, las rancherias y pequeñas localidades- se expresan diferencias e intereses divergentes. Esta forma de organización habia reforzado la supremacia de una élite de mayordomos de la cabecera municipal para mantener sus posiciones dominantes. Sin embargo, durante los últimos años se gesta una tendencia a autoorganizarse en el seno de las facciones para desligarse del excesivo control de los habitantes de la cabecera, estableciendo su propia capilla y el culto a sus propias imágenes.

La conversión religiosa por parte de un sector de la cabecera municipal, asi como de una parte de la congregación de Quechulingo, está dando lugar a una implementación de normas distintas, en un contexto social de incipiente conflicto y diferencias entre las facciones. La capacidad de éstas para hacer valer sus propias prácticas, ha debilitado relativamente la hegemonia de los principales o grupo de cargueros y sus posibilidades para cohercionar a los habitantes a participar en el sistema de cargos como servicio obligatorio.

Todo ello ha repercutido en la estructura de las relaciones entre las distintas instancias territoriales. El cambio religioso de grupos familiares aislados incide en una negación de las ayudas e intercambios, que colocan a los disidentes en una perspectiva desventajosa al prescindir del acceso a las redes de intercambio más amplias y, por ende, a las relaciones sociales que les proporcionaban cierta seguridad. Quizás por ello, en Atlahuilco se han dado casos de conversos protestantes que han regresado al seno de la Iglesia Católica después de profesar en La Luz del Mundo. Me aventuro a sugerir que no han soportado esta ausencia de sentido de comunidad que les proporcionaba su inserción en el sistema de cargos religiosos, garantía de cierta protección social.

La trascendencia de la conversión a nivel social se expresa en el rechazo de los conversos a participar en el sistema de intercambio y en su cristalización, la fiesta, uno de los espacios vigentes de cohesión. Representa una creciente desarticulación de los mecanismos arriba señalados, en la cual intervienen no solamente los conversos, sino también miembros de las nuevas generaciones que asumen un cambio de postura en torno al excesivo ritualismo y dispendio que impone el sistema de cargos o de mayordomias. Mientras aún la gran mayoria de habitantes del municipio defiende la tradición en torno al culto a los santos, algunas facciones se presentan a favor de ciertos cambios.

Estas manifestaciones parecen expresar una crisis de cohesion y de consenso. En la medida en que se prescinde de la participación en los rituales públicos, se 
evidencia una transformación en la noción colectiva del tiempo y el espacio sociales. La concepción del espacio local como un plano sacralizado mediante el movimiento ritual de las imágenes de los santos, se sustituye por una noción en la cual es la oración la que sacraliza al individuo. Paralelamente se transforman algunos ámbitos de la dinámica de las relaciones con el resto del pueblo no converso, por ejemplo, en la búsqueda de pareja exclusivamente en el seno de la congregación religiosa. El cambio religioso promueve mecanismos de diferenciación social más acordes con el ámbito de acción individual y el surgimiento de nuevas vias para la obtención de movilidad social, relacionadas con valores distintos al sistema de rotación de puestos del sistema de cargos religiosos.

El aumento en el número de habitantes, el cambio religioso y la introducción de algunos servicios en las facciones, son expresiones de este proceso de transformación del modelo de relaciones entre el centro y los parajes. El establecimiento de aulas escolares, la introducción de energia eléctrica y de caminos son elementos que reflejan la capacidad de la facción para independizarse. Especialmente las escuelas, por muy pequeñas que sean, representan para los habitantes de la facción una especie de adquisición de personalidad social reconocida por el conjunto. En Zacamilola, por ejemplo, congregación dividida en departamentos, se nombra a un subagente municipal por cada uno de éstos, el cual a su vez, debe coordinarse con el agente municipal $\mathrm{y}$ éste con el presidente municipal en turno, para la resolución de cualquier gestión o conflicto interno. A partir de que en el departamento de Xibtla se estableció una escuela con los tres primeros grados de la primaria -a fines de los años ochenta-, sus habitantes empezaron a desligarse del centro de la congregación y a reducir sus vinculos con el conjunto del poblado.

Aún cuando el establecimiento de una escuela es un elemento relevante para la adquisición de estatus social por parte de la sección, tiene mayor significación la instauración de un templo o capilla y con ello, de una festividad propia. La colocación de imágenes de santos al interior de la capilla (aunque sea solo una) permite a los habitantes del caserio prestar su servicio en el o los cargos religiosos sin sentirse obligado a participar en el sistema ceremonial general en honor de las imágenes del templo principal ubicado en la cabecera.

En el ámbito politico esta separación se expresa también de manera radical: autonomia religiosa y politica presentan cierta correspondencia. En fechas recientes, la cabecera municipal de Atlahuilco ha visto llegar contingentes de pobladores de las congregaciones y rancherias en demanda de una más eficiente gestion de los recursos públicos destinados a sus localidades. En ocasiones, rayando en la violencia, habitantes de Tepexititla, Atlehuaya, Zacamilola y Quechulingo, han exigido una participación más equitativa y un jercicio más transparente de los fondos, al mismo tiempo que han conseguido desplazar de los puestos públicos a las familias mestizas del centro para proponer a hombres 
de sus mismos parajes. Desde mediados de la década de los noventas, manifiestan un rotundo rechazo hacia la burocracia regional, hacia el sector político integrado por los maestros y hacia quienes identifican como pertenecientes a la clase de los funcionarios que durante décadas han utilizado su posicion en beneficio propio.

La tendencia hacia la descentralización de las cabeceras municipales como el centro politico-religioso se manifiesta de formas distintas -pero en la misma dirección- en otros pueblos de la sierra. En ocasiones, a través del ritual se afirman estas delimitaciones sociales; la instauración de un sistema de cargos propio, así sea de una sola imagen a la cual festejar, implica la demarcación de fronteras que sintetizan al mismo tiempo aspiraciones de carácter politico. En Tlalca, por ejemplo, paraje del municipio de Texhuacan, se ha instituido de manera muy clara la fiesta patronal como una festividad dirigida a reafirmar la identidad local.

Este lugar, hace una década habitado por unas quince familias dispersas por las pendientes de los cerros, hoy se integra por alrededor de 400 habitantes y es catalogado como "departamento" del pueblo de San Juan (cabecera del municipio cuyo santo patrono es San Juan Bautista). Sus pobladores recientemente levantaron una capilla en la que instalaron a San Isidro, patrono de los agricultores como su santo tutelar. En una búsqueda consciente de elementos étnicos de identificación han iniciado la realización de su fiesta patronal conjugando el culto a este santo católico con la realización del xochitlali, ritual agricola de claras referencias prehispánicas. Esta fiesta, en la cual convergen rituales agricolas, danzas tradicionales, culto al santo patrono y hasta competencias deportivas, resulta un claro ejemplo de un ritual festivo que conjuga ideologias interculturales como estrategia de definición colectiva.

Desde mi perspectiva estas escisiones tiene una relación estrecha con el surgimiento de cierta prosperidad económica en el seno de la facción o segmento. Las posibilidades de autoorganizarse refieren la capacidad de realizar festividades que requieren de recursos económicos. Por su parte, las autoridades y especialistas rituales de la cabecera, lamentan esta separación del sistema ceremonial general, puesto que antes de este proceso la unidad del caserio era mucho más informal y su vida social más supeditada al centro.

En el terreno político, esta clase de fracturas representan ciertas ventajas para los habitantes de la facción al liberar implicitamente a sus pobladores de la colaboración en faenas obligatorias para el municipio, siempre que tengan formas de servir en su propio paraje, al tiempo que toman posturas conjuntas en favor de propuestas políticas o de interés local, como en la gestión de servicios públicos o apoyos crediticios. Esta microautonomia no implica, sin embargo, una absoluta independencia ni una institucionalización formal de fronteras politicas, tampoco se trata de una separación total de las redes más amplias a nivel de la 
localidad. No obstante, es evidente que a medida que crece la importancia de los parajes, sus habitantes pueden aspirar a la obtención de mayores satisfacciones a sus demandas.

Se puede decir que en los últimos años, el sistema basado en diferencias de edad reguladas por la participación en el sistema de cargos y por las reglas de residencia que preveian un periodo obligatorio de residencia patrilocal, se dirige hacia otra dirección, en la cual estas categorias de diferenciación social resultan inadecuadas. Esta nueva estratificación, estimula también la conformación de nuevas formas de identificación grupal, como la adscripción a otras denominaciones religiosas, la vinculación a organismos y movimientos de carácter politico y la organización en torno a grupos de trabajo. Mi interpretación es que estas vias están sirviendo como pretexto para las facciones en la demanda de derechos para establecer grupos autónomos. Los cargueros por su parte, apelan a la manutención de la tradición como justificación cultural para ejercer su liderazgo tal y como lo ha señalado Jane Collier en el caso de Zincantan, Chiapas (1995). No obstante, el sentido de unificación de todos los segmentos a partir de la devoción al santo patrono es tan profunda, que se sostiene como el último pero más fuerte eslabón entre los habitantes del municipio, con excepción de aquellos sectores que han optado por la conversión religiosa. 


\section{CAPITULO V}

\section{EL UNIVERSO DE LOS NAHUAS: VISION DEL MUNDO $Y$ PROCESOS SINCRETICOS.}

Además de los santos católicos, Tlaltikpaktli, los Señores del Tlalokan, el Santo Sol y otras deidades, espiritus y esencias ocupan un sitio en el universo de los nahuas. En éste, se conjugan visiones que remiten tanto a concepciones prehispánicas, como a la tradición judeo-cristiana producto de la evangelización. Se expresa asi un pensamiento religioso conformado por distintos procesos de transformaciones, continuidades y sincretismos, los cuales se han desarrollado desde la posición subalterna que mantiene la población india en la dinámica sociocultural mexicana.

Desde mi punto de vista, uno de los resultados fundamentales de este proceso, fue la religiosidad pública institucionalizada en torno a las imágenes de los santos católicos, y la función que cumplen estas entidades en la vida social de diversos pueblos indigenas hoy en dia, tal y como hemos visto en los capítulos precedentes. Este culto "santocéntrico" (Maurer, 1996: 57), es una de las expresiones religiosas que se produjeron entre la linea de la antigua tradición indigena y la doctrina cristiana introducida durante la colonia. Estas prácticas y creencias darian lugar a lo que Báez-Jorge entiende como paralelismo ritual o simultaneidad cúltica. El sincretismo religioso concreta una función de intermediación y equilibrio cuando existen canales compartidos de comunicación simbólica. La catequesis produjo, por tanto, articulaciones simbólicas, epifanias sincréticas, cultos paralelos y desplazamiento de las divinidades prehispánicas, con variaciones de forma y contenido (1988: 327-339).

En este capitulo me interesa mostrar que entre los nahuas de Zongolica se encuentran vigentes los ámbitos numinosos correspondientes a la Madre Tierra, asociados a la gestación, al nacimiento y a la fertilidad, así como otras deidades relacionadas con el subsuelo, las montañas, cerros y cuevas. Presento información etnográfica relativa a la visión del universo de los nahuas de Zongolica, dirigida a sustentar que pueden ser ubicados dentro de la tradición mesoamericana. Al mismo tiempo pretendo dar cuenta de ciertas particularidades, no obstante que forman parte de un mismo fondo conceptual. Presento asi mismo, una visión acerca de las imágenes de los santos como entidades per se y de los componentes que integran a la persona, en tanto forman parte de las concepciones básicas del universo de los nahuas.

Báez-Jorge sugiere que la Madre Tierra fue una de las categorias ideológicas que mostró mayor dinamismo y tendencia a la transformación durante el proceso colonial. De tal manera, sus esferas numinosas correspondientes a la fertilidad y la reproducción vegetal y humana, influyeron en la incorporación de un ciclo 
ritual regido bajo las categorias de tiempo y espacio. Esta categoria, al separarse de sus advocaciones, permitió que éstas se insertaran en las categorias de los santos católicos y que la Madre Tierra continuara como patrona de la fertilidad y de la reproducción vegetal y humana. A partir de un esquema simbólico común que López Austin expresa en el concepto de religión mesoamericana-, se desarrollaron versiones cúlticas regionales (Báez-Jorge, 1988: 167). El culto a la Madre Tierra permaneció dentro del proceso de cristianización de las divinidades autóctonas.

Desde esta óptica, es posible plantear que en la religiosidad nahua pueden distinguirse procesos sincréticos como en el culto a los santos católicos, como cultos paralelos, expresión de un claro sustrato prehispánico. En este último sentido destaca la existencia del Tlalokan como un ámbito subterráneo de riqueza y abundancia que desemboca en las cuevas de las montañas y es morada de los tlalokes, deidades relacionadas con las lluvias, los animales silvestres y la vegetación. De entre las diosas madres, predomina la Madre Tierra como madre nutricia y protectora. En la existencia de esencias y espiritus vemos que las fuerzas se dividen y se componen, la coesencia es una de sus caracteristicas, prolongaciones del poder de sus dioses (López Austin, op. cit., 195).

Los cultos populares ligados a la agricultura integraron en esta recarga numinosa a los santos católicos, al tiempo que consolidaron a los santos epónimos como referentes de las identidades locales en los pueblos de indios. Es decir, los atributos sagrados de los santos fueron modificados, tomando un lugar sustancial en la dinámica social de los pueblos colonizados. Como resultado de la diversidad de procesos que ha sufrido el sustrato cultural mesoamericano, la superestructura construida en torno a la Madre Tierra, arraigó en los pueblos cultivadores de maiz, quienes vinculan aún hoy, a la madre telúrica con las montañas y las cuevas, evocando el antiguo sustrato de "la religión de los tlaloques" (Báez-Jorge, op. cit.: 226-230).

Para López Austin es evidente la existencia de una tradición religiosa mesoamericana; apunta la conveniencia de partir de un reconocimiento hacia lo que denomina complejo religioso mesoamericano: "un conjunto estructurado de procesos sociales, creencias, prácticas, valores y representaciones que se van transformando a lo largo de los siglos" (1994: 11). Esta tradición religiosa incluye formas de pensamiento en las cuales la religión mesoamericana y la religión impuesta por los evangelizadores, se integraron en una misma corriente histórica. La existencia de un vigor diferencial en los lineamientos de ambas tradiciones y su vigencia, hacen de esta tradición un proceso no solo histórico, sino contemporáneo, vital y dinámico.

López Austin ha propuesto que dado que en la cosmovisión mesoamericana -y en la religión mesoamericana en general- existe un núcleo unificador, los resultados 
de las investigaciones pueden ser utilizados en la construcción de modelos interpretativos aplicables a otros segmentos del mismo hecho histórico; los conocimientos etnográficos pueden ser muy útiles para el entendimiento de la cosmovisión antigua.

Si bien la delimitación de Mesoamérica como categoria histórica y espacial se elabora inicialmente desde la arqueologia, y a la luz de elementos proporcionados por la investigación dentro de esta disciplina, estudiosos de distintas ramas de la antropologia y de la historia, la han utilizado desde variadas perspectivas e intereses. López Austin, por ejemplo ha planteado el estudio de la cosmovisión mesoamericana limitando el nombre de Mesoamérica a la época anterior a la conquista española, pero sugiriendo el estudio de las formas de persistencia y los elementos comunes en los pueblos que proceden de esta tradición (1994: 12). Si bien esta área no debe considerarse como un espacio históricamente autónomo, dado que existen una gran cantidad de elementos comunes entre pueblos de distintas tradiciones y ubicaciones espaciales -por ejemplo con el àrea norteña de México conocida como Aridamérica-, el concepto ha sugerido la existencia de cierta homogeneidad entre distintos pueblos, con base en una serie de rasgos comunes.

La categoria de Mesoamérica fue acuñada por Kirchhoff en 1943, cuando estableció los límites, composición étnica, y expresiones culturales de esta superárea. Kirchhoff aplicó un modelo descriptivo estático, partiendo de la enumeración de caracteristicas especificas que hacia el siglo XVI permitian ubicar a estos pueblos como cultivadores superiores, a diferencia de los cultivadores inferiores y los cazadores recolectores de las áreas vecinas.

Esta caracterización ha sido objeto de polémica -se cuestiona, entre otros aspectos, que se incluyan elementos que aparecen en una determinada zona de la superárea y que sin embargo se presentan en otras regiones de América- sin embargo, representó en cierta forma una solución conceptual ante la diversidad etnolingüistica de una importante franja de la nación mexicana; se constituyó en una propuesta válida para comprender el desarrollo histórico y cultural de esta vasta área. Eric Wolf (1986), por ejemplo, concibió a Mesoamérica como un territorio con dos provincias gemelas, México y Guatemala, delimitado por montañas que rodean las tres mesetas que lo integran: la meseta central en la parte sur del centro de México, la meseta meridional al sur de México, y la meseta que se orienta hacia el extremo sureste entre México y Guatemala. Para Wolf, estas áreas han funcionado como un sistema en términos de relaciones sociales, en el cual el valle de México es el corazón, el centro del poder politico. De este modo aplica la categoria como resultante más de la dinámica histórica de la región que del conjunto de rasgos culturales, como inicialmente la desarrolla Kirchhoff.

Desde mi punto de vista, la aplicación de la categoria de Mesoamérica ha hecho 
posible el desarrollo de estudios comparativos en dicho ámbito histórico y espacial, en el cual se ha manifestado, de acuerdo con López Austin (1980, 32), la existencia de una relativa unidad de cosmovisiones, emparentadas por comunidad de origen, por comunicación constante y desarrollo paralelo.

\section{Aculturación y Procesos Sincréticos.}

Evidentemente, el complejo mágico-religioso se constituyó en una de las manifestaciones más notables de la resistencia de las culturas indigenas. Aún cuando en determinados campos este complejo se mantuvo diferenciado de las formas precoloniales, en otros se manifestó una clara continuidad de elementos de la antigua tradición indigena. Dicha continuidad remite a los rasgos culturales de larga duración que constituyen los núcleos sobre los cuales se desarrolla el sincretismo (Segre, 1990: 21).

Los santos católicos revistieron de nueva identidad a los antiguos dioses, venciéndolos en una batalla simbólica y eliminándolos del cuerpo de deidades que configurarian el panteón de los pueblos indios colonizados. Madsen (op.cit.) califica al periodo de resistencia hacia la adopción del cristianismo como de disonancia cognitiva; el rechazo hacia esta doctrina encontraria cierta consonancia a partir de la desconfianza adquirida hacia los dioses nativos como consecuencia de la derrota ante los conquistadores; de ahi que este autor considera significativo que el culto a los dioses de la lluvia, por ejemplo, sobreviviera a la conquista mientras desaparecía el referente al dios de la guerra.

Ello explicaria según Enzo Segre (comunicación personal), la preeminencia en los pueblos indígenas y campesinos de hoy en dia, de los santos guerreros como San Miguel Arcángel y otros santos espadachines ${ }^{1}$, y al mismo tiempo la permanencia de las deidades prehispánicas relacionadas con fenómenos ajenos a la guerra y el sacrificio: aquellas dedicadas a las fuerzas naturales, al inframundo, a los dueños de los animales, de los montes, del subsuelo y en general del entorno natural. Haciendo referencia a la narrativa indigena de San Miguel Tzinacapan, Segre (1990) señala que algunas narraciones atestiguan una larga fidelidad hacia sus raices prehispánicas, mientras que otras son profundamente sincréticas, en las cuales los códigos culturales indigenas han reinterpretado los materiales europeos; durante el proceso de aculturación los códigos translingüisticos originales se pierden, asimilándose a los de las culturas indigenas y dando lugar a nuevas narraciones, mediante la reorganización de los motivos de origenes diversos y transformándose en un vehículo de nuevos significados.

\footnotetext{
1 En Atlahuilco, durante las cuatro festividades más importantes del calendario religioso anual, la imagen de San Miguel Arcángel, blandiendo su espada, encabeza el desfile de los santos que cargados en hombros y antecedidos por una banda de música $y$ un grupo de danzantes, rodean el templo principal acompañados por la procesión de los fieles.
} 
Determinadas categorias no lograron atravesar lo que Burkhart (1989) denomina la "frontera dialógica", sino solamente cuando éstas fueron compatibles con creencias preexistentes. Para Segre muchas narraciones indigenas son traducciones-traiciones, en la medida en que los códigos culturales indigenas, han reinterpretado los materiales europeos, mientras que otras atestiguan una larga fidelidad a la tradición prehispánica. En el primer caso, los códigos translingüisticos originales se pierden y muchos motivos son absorbidos por los códigos translingüisticos de las culturas indigenas. Las constantes en el pensamiento mitológico mesoamericano no excluyen la existencia de variantes locales que se impusieron al entrar en contacto con la cultura del viejo mundo.

(op. cit.: 13-16).

En el curso de la evangelización que para Nutini (op. cit.) consistió en un proceso de "sincretismo guiado" -dado que se orientó a promover la conversión rảpida realizando concesiones doctrinales, rituales o litúrgicas- la resistencia étnica se expresó a través de la reelaboración de determinados conceptos impuestos, manteniendo una orientación ideológica propia bajo la mirada cómplice de los frailes misioneros como lo expresara Burkhart (op. cit.).

Durante el proceso de traducción, conceptos cristianos como la división entre cuerpo y alma y el destino post-mortem, serian aspectos que no encontraron fácilmente su correspondencia en el pensamiento mesoamericano, en el cual el destino después de la muerte dependia de la manera en que el individuo había fallecido. El más allá era diverso y no intervenia noción moral alguna en la asignación de la morada post-mortem; los dioses elegian el género de muerte de cada hombre. Quienes no habian sido elegidos para gozar de la inmortalidad como las mujeres muertas en el parto, los niños que fallecian antes de nacer, los guerreros que entregaban su vida en el campo de batalla-, tenian el Miktlan, el inframundo como destino común, transición hacia la desaparición total del ser. El Miktlan se localizaba en el más bajo nivel del inframundo, pero no poseia la connotación cristiana del infierno como lugar de castigo para quienes en vida obraron contra el orden y la moral establecidos. (Soustelle, 1983: 138-144). E1 destino final de los muertos se definia pues por las circunstancias en que cada persona moria, y era una manera de integrarlos en el séquito de determinados dioses. Por ejemplo, quienes morian en batalla acampañaban a Huitzilopochtli - a Tezcatlipoca, mientras que los que morian ahogados residian en el. Tlalocan como ayudantes de Tlaloc. La celebración a los muertos se distribuía a lo largo del año, en función de las fechas asignadas para cada clase de deceso.

La evangelización, si bien en términos generales persiguió el objetivo de la conversión masiva de los indios y el abandono de la idolatria, implicó una diversidad de formas que no sólo variaban en función de una a otra orden religiosa, sino incluso, como señala Burkhart (op. cit.), de uno a otro fraile. El contraste cultural dio origen a la inevitable frontera de traducción, la cual impidió el paso de determinadas concepciones básicas relativas al cosmos, pero 
incorporó otras, como el panteón habitado por los santos católicos. De este modo, el sincretismo se expresó como una solución ante las contradicciones inherentes a la traducción de conceptos y categorias. Ello resultó en lo que Burkhart entiende como conocimiento intermedio entre elementos complementarios, y que Durán registró con el término nepantla (encontrarse en medio), concepto nahua que expresaria de forma sucinta el resultado sincrético.

La cultura medieval de la España del siglo XVI se mezcló con la cultura del postclásico mesoamericano, según lo resume Segre en la siguiente cita:

"La luna se sincretizó con la Virgen Maria; Tlaloc con San Juan Bautista o con el Demonio; los tlaloques, servidores del Dios de la Lluvia, con los demonios menores; de nuevo, San Juan con la estrella Venus-Quetzalcóatl, luz del alba; después, Cristo con el Sol; las estrellas con los santos; ... la madre tierra con la Virgen Maria; el ángel guardián se emparentó con el tonal y el doble animal..." (1990: 19-20)

La evangelización y los procesos de sincretismo no fueron homogéneos, la permanencia del núcleo de creencias religiosas de origen prehispánico, asi como las reelaboraciones de la doctrina cristiana tuvieron un margen de variabilidad de una a otra región, de uno a otro pueblo. Esta diversidad de procesos generó la gestación y desarrollo de tradiciones locales que sobrevivieron a los intentos de hegemonia de las élites estatales y de las instituciones de la iglesia y el gobierno.

Para Madsen (1975) durante el proceso de evangelización adquirió suma importancia la transmisión generacional en la adopción de los nuevos valores cristianos: mientras que en los niños se inculcaba el rechazo al culto de los dioses considerados paganos, los adultos colocaban idolos atrás de las imágenes de los santos católicos. Para este autor, fue ésta la primera forma de sincretismo de las formas indias y católicas: la simple adición de nuevos dioses, asunto de sumo conocido para los mexicanos, habituados a incorporar deidades de los distintos pueblos con los cuales mantenian interacción para el comercio o la guerra.

Aunque algunos frailes, como Fray Bartolomé de las Casas, no ocultaban su rechazo hacia esta forma de sincretismo, resultó más o menos común el esfuerzo por estimular la adopción del cristianismo a través de la adaptación de canciones y danzas de carácter prehispánico con motivos cristianos, las cuales resultaron exitosas en tanto propiciaron la participación colectiva en las ceremonias católicas, aunque ello no garantizara la conversión profunda en las conciencias de los indios. Según Madsen, la aceptación real de la nueva fe se dio a partir de la aparición de la Virgen de Guadalupe, sin embargo aún hoy es evidente que el carácter de los ritos propiciatorios agrarios permaneció en una amplia gama de contextos. 
Jacques Lafaye señala que el cristianismo se vio contaminado cuando los indios iniciaron la adopción de símbolos, asi como su supuesta eficacia mágica, conservando su antigua religión al nivel rutinario del ritual (1985: 63). Así mismo, reconoce que el encuentro entre las divinidades de papel definido del panteón mexicano, y el culto a los santos protectores locales dio lugar a sustituciones y asimilaciones. Existió una multiplicidad de focos de aparición de creencias sincréticas y de prácticas mágicas especificamente mexicanas, puesto que en la Nueva España confluyeron aportaciones religiosas heterogéneas, aportaciones de minorias que durante el contacto con las restantes sufrírian préstamos, modificaciones y sustituciones, adquiriendo un carácter residual debido a las presiones de la ortodoxia católica. (op. cit.: 71).

En los pueblos indigenas de hoy, el ámbito de lo sagrado se enmarca pues en una secuencia histórica en la cual el contacto entre culturas dio lugar a formas sincréticas, a procesos selectivos y a traducciones propias desarrollados en el contexto de la posición subalterna. Foster ya señalaba que todo proceso de aculturación implica el contacto entre grupos y supone cambios en ambas culturas (1962: 27). Desarrolló el concepto de "cultura de conquista" como contraparte del enfoque que centra su atención en la reacción del pueblo receptor ante un grupo dominante donador; sugiere este modelo teórico para referirse a la actuación de una cultura dominante en una situación de contacto. En dicha situación, según este autor, se verifica una selección entre la totalidad de los elementos que se encuentran en una cultura donadora, a los cuales se añaden otros que aparecen o se desarrollan como resultado de la propia situación de contacto (op. cit.: 35). Es decir, en el modelo de Foster se da por supuesto que en algunos casos la "cultura de conquista" implica una cierta dosis de planificación y selección de los elementos que se desea sean incorporados en el pueblo receptor.

Para Aguirre Beltrán, el principio fundamental que determina el fenómeno de la aculturación es el conflicto entre elementos de culturas antagónicas. Entiende la aculturación como

"el proceso de cambio que emerge del contacto de grupos que participan de culturas distintas. Se caracteriza por el desarrollo continuado de un conflicto de fuerzas, entre formas de vida de sentido opuesto, que tienden a su total identificación y se manifiesta, objetivamente, en su existencia a niveles variados de contradicción". (1957: 49)

Según este autor, la interacción cultural puede hacer variar los patrones originales de los grupos en conflicto, los cuales mientras permanecen diferentes, continúan en un intercambio de elementos y en una lucha incesante de sus opuestos. Sin embargo, estas contradicciones tienden a ser superadas dando origen a una nueva unidad que inicia un desenvolvimiento propio, el cual se desarrolla mientras los elementos originales se ven menguados hasta 
extinguirse. Aguirre Beltrán hace hincapié en el carácter dinámico del proceso de aculturación, apuntando que éste involucra un conjunto infinito de procesos entre elementos opuestos de dos culturas, los cuales se interconectan actuando reciprocamente unos sobre otros y en un desarrollo incesante. En el proceso de aculturación se manifiestan pues elementos opuestos de las culturas en contacto.

En este planteamiento, Aguirre Beltrán critica los enfoques de Redfield, Linton y Herskovits, quienes desde su punto de vista, conciben el proceso de aculturación como un fenómeno acabado, tomando como resultantes las fuerzas opuestas en interacción. Para aquél, tanto las reacciones en contra de los elementos de la cultura impuesta como las tendencias hacia la aceptación, no son términos o resultados del proceso sino expresiones de la posición de elementos que se conjugan e interpenetran, y por lo tanto varian en el tiempo y en el espacio. Esta variación se expresa en un continuum adaptativo que va desde una adaptación comensal en que ambas culturas coexisten con sus elementos sin alteraciones básicas, hasta una adaptación sincrética en la cual se combinan las contradicciones y se origina una nueva cultura. Aguirre Beltrán llama integración a este proceso de cambio, emergente de la conjunción de grupos que participan de estructuras sociales distintas. (op. cit.: 51-53). Para este autor el examen de las situaciones aculturativas proporciona un enfoque instrumental o pragmático, mismo que debe dirigirse a propiciar la integración regional en las regiones interculturales. Estas ideas serian la base de la teoría y acción indigenistas.

Aguirre Beltrán ilustró el proceso de aculturación en el México colonial en su libro Medicina y Magia (1980). En él explica el proceso de conjugación de rasgos y complejos culturales opuestos en el contexto de una sociedad divida en castas. Plantea que los años de 1614 a 1630 fueron aquellos durante los cuales el proceso de aculturación alcanzó su momento más relevante. En dicho periodo ocurrió la importación de mano de obra esclava como consecuencia de las epidemias que diezmaron de manera catastrófica a la población india. No obstante, la cultura indígena inició entonces un renacimiento que penetró incluso en diversos campos de la cultura conquistadora, especialmente el de la medicina.

Según el autor, en este ámbito se dio el más bajo nivel de aculturación entre la medicina indigena y la medicina española. La situación aculturativa, acorde con la sociedad de castas en conflicto, propició que entre ambos sistemas conceptuales existiera una conversion paralela en la cual ambos grupos aceptaron la interdependencia. De este modo, se explica que, incluso en la actualidad, determinadas prácticas médicas conserven ideas y patrones de acción que las identifican como indigenas (op. cit.: 255-277). No obstante, se puede hablar también de un proceso sincrético, resultado de la interacción entre uno y otro sistema médico y de las analogias existentes entre ambos. Quezada 
(1989) plantea que algunas prácticas médicas indígenas se presentaron en la Colonia como puntos de resistencia a la sociedad dominante

Es decir, el proceso de transculturación se conformó por movimientos contraculturativos que cumplieron una función de respuesta ante la cultura impuesta por los conquistadores, sin embargo también se dio la conjugación de elementos de las distintas tradiciones culturales. En esta sincretización, las culturas indigenas desde su posición subalterna, cimentaron las vias para la conformación y permanencia de la identidad de sus pueblos y comunidades. De acuerdo con Segre seria más apropiado el concepto de transculturación en sustitución del de aculturación, para referirse al proceso que dio lugar a formas sincréticas a partir del contacto cultural. El término transculturación resulta más adecuado en la medida en que implica una concepción dinámica que no se refiere unicamente a la acción del pueblo donador sobre el receptor, sino también a los fenómenos de respuesta (contraculturativos) y de supresión total de determinadas expresiones culturales (deculturación). Es desde esta perspectiva que puede explicarse la fuerza de sistemas conceptuales propios del mundo indigena.

Al igual que otros estudiosos, Marzal (1996) plantea que la visión indigena del dios cristiano proviene de los esfuerzos de los frailes por hacer el mensaje cristiano más comprensible, por lo que conserva ciertos rasgos de la religión original. De tal manera, el sincretismo fue un proceso mediante el cual aquellos que fueron evangelizados trataron de retener vestigios de su propia religión, no oponiéndose a la nueva, sino adaptando los nuevos contenidos en formas apropiadas a la religión original. Marzal considera que las religiones indigenas han realizado contribuciones importantes al cristianismo: una dimensión sagrada de la ecologia, el papel de los sentidos en la experiencia religiosa, ciertas formas de animismo, la diversidad de formas de acercamiento a la divinidad, la unidad de la persona en cuerpo y alma (op. cit.: 20). Refiriéndose especificamente a la religión quéchua, (pero en coincidencia con las tradición religiosa mesoamericana) Marzal señala que es posible precisar sus dos ritos básicos: la celebración al santo patrono, de origen católico y la ofrenda a Pachamama, la Madre Tierra; en torno a éstos, los santos, las fiestas y los milagros, sintetizan su experiencia religiosa. (op cit.: 70).

En opinión de Nutini y Bell (1989: 295-296), uno de los ejemplos más claros del manejo de las identificaciones sincréticas por parte de los franciscanos, fue la selección y adaptación de los santos patronos. Esta adaptación intentaba asociar a los dioses especificos relacionados con determinadas comunidades y con la especialización de éstos en el panteón mesoamericano. Es decir, implantaron el ritual y el culto de los santos católicos identificándolos con los dioses nativos; bajo una mirada que consideraba similitudes estructurales, funcionales 0 simbólicas. Una de las metas que perseguia esta estrategia, era propiciar una conciencia de la comunidad de especie usando el valor simbólico de la 
identificación dios-santo.

En coincidencia con dicha interpretación, Aguirre Beltrán (1986) señaló que en la sierra de Zongolica, los franciscanos asignaron a los santos patronos de cada pueblo, persiguiendo su sincretización con los dioses nativos y enfatizando el martirio sufrido por aquellos, de frente a la idea mesoamericana de sacrificio. Analiza el significado abscondito de los topónimos locales y la adjudicación de los santos patronos correspondientes. Plantea, por ejemplo, que desde su punto de vista es evidente el sincretismo de Mixcoatl, dios de la caza, con San Francisco de Asis, patrono del pueblo de Zongolica, cuya personalidad y atributos son exactamente los opuestos a los que configuran la imagen de la deidad nativa y sus distintas advocaciones.

"Los franciscanos, pues, ponen frente a frente, en contacto de primera mano, a elementos contrarios para que mediante el conflicto resultante, se conjuguen los opuestos" (1986: 104).

Desde otra perspectiva de análisis, se han señalado evidencias acerca la importancia de la organización social y religiosa de Mesoamérica, para la conformación de los pueblos indigenas durante el sistema colonial. El capulli, por ejemplo, se fundamentaba en la creencia de un origen mitico. Cada calpulli contaba con uno o varios dioses protectores de sus sementeras y del bienestar de sus habitantes. Constituia un núcleo de población con especialización económica y artesanal y con un sistema no estricto de matrimonio de tipo endogámico. Los apellidos estaban ligados al calpulli y éste a un dios particular, el dios protector, el corazón del pueblo, altepetl iyollo (López Austin, 1973). Las caracteristicas del dios patrono del calpulli remiten a la noción de totemismo, tal y como se refiriera Frazer (1946) al totem de clan: un sistema social y a la vez religioso resultante de la existencia de un totem, objeto de culto que da nombre al grupo y que implica ciertas relaciones especiales entre los miembros de un mismo clan y entre miembros de clanes diferentes. Segre (comunicación personal) sugiere que el patrono del calpulli representó un vestigio de totemismo.

La complejidad social, que incluia jerarquias de grupos y subgrupos, hacia relativa la relación entre un grupo humano y un dios patrono. Es decir, existian, según López Austin (1994), desde dioses patronos para grandes conglomerados hasta dioses del calpulli e incluso dioses familiares. El dios patrono otorgaba el alma a los individuos por él creados, alma que no sólo los hacia hombres sino que les daba pertenencia grupal. Al enlazarse miticamente con el origen del grupo, el calpultéotl, dios tutelar, ocupaba una posición prioritaria para sus protegidos y la existencia de la comunidad dependia de su protección. La vida, la salud y la reproducción individual y colectiva derivaba del calpultéotl. López Austin equipara el calpultéotl con los santos patronos actuales de los pueblos indigenas. 
Carrasco (1979) también sustenta la idea de que durante el siglo XVI surgió un sistema religioso doble, puesto que la religión aborigen se refugió en la clandestinidad, mientras se aceptaba en apariencia la nueva religión; sobrevivieron principalmente aquellos ritos asociados al ciclo de vida, a las curaciones y a las actividades técnicas como la cacería y la agricultura. Además se produjo una combinación de elementos centrada en la identificación de los dioses indigenas con los santos católicos: ambos eran patronos de las actividades y los grupos humanos, estaban relacionados con los fenómenos naturales, se les adoraba en templos especiales y en dias determinados, eran antropomorfos y el culto era dirigido hacia una imagen.

En la medida en que prevaleció el culto público a los santos católicos, los dioses prehispánicos que sobrevivieron en los ritos privados se convirtieron en espiritus, con casi ninguna conexión con los santos. En las comunidades indigenas se promovieron nuevos ritos de identificación alrededor del culto católico, el cual ganó importancia en su vida politica y económica. De este modo, los indigenas tomaron en sus manos el culto a los santos, patronos de pueblos y barrios, y se marcó la distancia entre la iglesia y las formas locales de culto. La relevancia del sistema de escala o sistema de cargos, según Carrasco, radicó en el hecho de que fue el hilo que conectó las formas precolombinas con las formas modernas de organización politica y ceremonial (op.cit.: 24-29)

Sin embargo, ¿cómo explicarse la unidad y persistencia en las prácticas rituales de los pueblos indigenas habitantes del área mesoamericana? López Austin lo explica apoyándose en el concepto de arquetipo: el desarrollo del cultivo del maiz es una de las causas primordiales de la unidad histórica de Mesoamérica; este común denominador permitió que la cosmovisión y la religión fueran los vehículos de comunicación entre los diversos pueblos mesoamericanos. El hecho de que la lógica básica de este complejo radicara en la actividad agricola, permitió que la cosmovisión tradicional continúe vigorosa hasta hoy, no obstante la destrucción de instituciones y la desaparición de sacerdotes y sabios (op. cit.: 16).

\section{b) Los dioses, espiritus y esencias de los nahuas serranos.}

López Austin (1980: 58-59), al referirse a la estructura del cosmos de los pueblos mesoamericanos, destaca la concepción común de una oposición dual de contrarios que divide al cosmos, pares polares y complementarios como arriba y abajo, hombre y mujer, frio y calor. Relacionados entre si por su oposición en uno de los grandes segmentos, se ordenan en una secuencia alternativa de dominio.

Actualmente, para los nahuas de la sierra de Zongolica la división dual fundamental se expresa en la división entre frío y caliente, la cual remite a la 
proyección del dualismo cosmológico. A partir de esta oposición básica se clasifica al cosmos y sus sustancias, esencias y espacios. En lo que respecta a la integridad corporal de los humanos, gran parte de las acciones rituales y terapeúticas de los nahuas están dirigidas hacia la consecución del equilibrio entre estos dos polos. En esta concepción bipolar del universo, el frio es la calidad con una mayor carga negativa, puesto que se asocia con la muerte. Esta clasificación no se basa en la temperatura de las cosas, cuerpos o productos, sino en su cualidad o naturaleza que les permite ubicarlos en el seno de este sistema taxonómico.

La clasificación de las sustancias, esencias, materias y espíritus en frios y calientes expresa esta polaridad y define sus efectos sobre las personas. El frio se relaciona con el mundo subterráneo, con la muerte, con lo no domesticado como el monte y los animales silvestres y con el abajo, lugar de humedad y verdor. Los alimentos crudos, incluida el agua, se consideran frios y por lo tanto, dañinos para el organismo. Por ello, el monte, las cuevas, los manantiales y caminos abandonados, los cementerios y los funerales son lugares peligrosos per se. Las cualidades asociadas a la parte femenina del universo son frias y hasta cierto punto malignas, mientras que lo masculino es caliente y vital. De esta clasificación primaria se derivan una serie de equivalencias que rigen la concepción del universo de los nahuas.

López Austin se ha manifestado en desacuerdo con la idea de que la oposición dual frio-calor que se aplica a la medicina y a los alimentos en la cosmovisión indigena contemporánea, provenga de la doctrina del humorismo del sistema hipocrático europeo. En su polémica con Foster -quien planteó que las concepciones americanas derivaban de la teoria de los humores, y que al pasar al marco popular indigena se perdieron los criterios de humedad y sequedad-, López Austin argumentó que existen serias posibilidades de que la polaridad tuviese origen americano ya que no se reducia al campo de la salud y la medicina. Hoy en dia como mencionaba líneas arriba refiriéndome a la concepción de los nahuas de Zongolica, la polaridad frio-caliente se extiende a todo el cosmos; de acuerdo con este autor, si derivara esta clasificación de la teoria hipocrática, se referiria únicamente al terreno de la salud y la enfermedad.

El mismo autor expresa que el concepto americano se encuentra en concordancia con la división general del mundo en Tierra y Cielo como mitades sexuadas. (op. cit.: 306-318). Presenta datos relativos a registros del siglo XVI que prueban que desde épocas muy tempranas los indios dividian las enfermedades y medicinas en frios y calientes, razón por la cual se desarrollaron procedimientos terapéuticos mediante los cuales se pretendia equilibrar el organismo tomando como base la dicotomia frio-calor. Por otra parte, argumenta que es extraño que no se haya conservado en ningún grupo indígena la cuádruple división hipocrática que incluía también la división sequedadhumedad. El hecho es que en la actualidad en las concepciones de los nahuas 
sigue siendo básica dicha dicotomía y en ella se apoya la divisiôn dual del cosmos. Los esfuerzos de los individuos se dirigen hacia la búsqueda de la armonia individual y el equilibrio entre los distintos elementos de la naturaleza, de acuerdo a su ubicación en el seno de esta división dual.

Para los nahuas el entorno físico se clasifica tambièn a partir de la oposición arriba/abajo, que corresponde a la de calor/frio. El arriba es para los nahuas serranos la parte benéfica y de naturaleza cálida. No obstante que el clima predominante es húmedo y frío la mayor parte del año, los nahuas de las tierras altas consideran las cañadas, plantaciones y planicies de la tierra caliente como lugares de naturaleza fria, perniciosos, insalubres y hostiles. Según los nahuas, es común que los hombres que emigran a las plantaciones de caña para trabajar como jornaleros agricolas, enfermen si no toman las precauciones debidas, como no beber agua -elemento de naturaleza fria-, a pesar del calor. Es preferible ingerir café tibio endulzado o refrescos embotellados sin refrigerar, puesto que se dice de hombres que han muerto en los cañaverales, con su cuerpo hinchado a causa de una inmoderada ingestión de agua.

Las funciones femeninas como las menstruaciones, los partos y el puerperio, se consideran estados físicos impuros en los cuales las mujeres adquieren extrema frialdad y consiguen, sin proponérselo, contaminar su entorno inmediato. Por ello, las parturientas deben tomar una serie de baños de vapor en el temaskal, mismos que cumplen simultáneamente la función de purificación y de equilibrio en la temperatura del cuerpo. Las ropas utilizadas durante el parto deben lavarse en alguin manantial o arrollo suficientemente lejano del poblado, con la finalidad de que no contamine las aguas utilizadas para el uso cotidiano; estas prendas no deben ser vistas por ninguna otra persona además de la comadrona, de ahi que López Austin se haya referido a las parteras como "especialistas de lo sucio" (1994: 133).

Los cuidados del posparto dependen básicamente de ingerir alimentos de naturaleza caliente o que se encuentrer en una posición de equilibrio entre los extremos frio-calor, y de la realización de una serie de siete baños de vapor en el temaskal, aromatizados con hierbas de uso terapeútico. Pero además de purificar a la parturienta, también es indispensable realizar la ofrenda de flores a la tierra (xochitlalli), en un ritual dirigido a invocar su perdón por haberla ensuciado y a pedir el reestablecimiento de la enferma. El ciclo de purificación de la cuarentena se sella con la realización de dos ceremonias de xochitlalli: una que se realiza en el interior del temaskal una vez concluida la serie de baños y otra que se lleva a efecto junto al lecho de donde la mujer dio a luz.

Las deidades de los nahuas se ubican también en el seno de esta concepción bipartita del universo: las deidades húmedas, frias, nocturnas que habitan en el subsuelo y las deidades terrestres, solares y diurnas que habitan en la superficie y en el espacio celeste. Algunas deidades frias desprenden o emanan vientos o 
espiritus (ehekame) que transitan por espacios de los cuales son "dueños" o cuidadores, donde los seres humanos pueden percibirlas, provocando alteraciones en el equilibrio del organismo y estados de aflicción. Su ubicación remite a esta división holistica en pares de oposición caliente/frio, arriba/abajo, vida/muerte, los cuales López Austin considera puntos nodales del pensamiento mesoamericano. (1994: 160).

En la parte superior del cosmos, seca y cálida, habitan los hombres, cuyas necesidades de supervivencia les hacen depender estrechamente del sol y de la tierra. La Madre Tierra, Tlaltikpaktli, es la deidad que amalgama el simbolismo agrario y telúrico, dispensadora de la fertilidad. El Santo Sol y Jesucristo, Totahsin, residen en el cielo, al igual que los santos católicos.

El Sol y Jesucristo se originaron al mismo tiempo, segün un mito cosmogónico en el que se hace explícita la conexión entre el astro y el dios cristiano. En este relato se narra que el sol y la luna surgieron del fuego y las cenizas de una pareja de hermanos que murieron calcinados. El calor de los rayos del sol no destruye el mundo de los hombres porque Jesucristo antecede su aparición en cada amanecer, protegiendo al mundo entero y anunciado por el canto matutino del gallo. Este es el único animal que tiene el privilegio de anunciar diariamente el arribo de Jesucristo y del sol, puesto que cuando el mundo estaba aún en tinieblas y ante la desesperación de los hombres por saber cuándo llegaria la luz, esta ave dio respuesta anunciando que pronto saldrian los rayos del sol desde el horizonte. Los demás animales permanecieron ajenos e ignorantes a estas preguntas y por ello fueron castigados privándolos de la capacidad de hablar. El sol se formó de las brazas aún encendidas en que se convirtió uno de los dos hermanos, mientras que la luna es el resultado de las cenizas, ya sin fuego, del otro, por ello su luz es débil y tenue.

Esta pareja de hermanos, protagoniza en el mismo relato un enfrentamiento con un venado, su padre resucitado, quien en vida habia sido asiduo cazador de animales de monte y con cuya carne alimentaba a su familia. Sus hijos, siendo ya a su vez jóvenes cazadores, lo asesinan en su reencarnación animal, después de descubrir que su madre viuda lo visitaba y alimentaba diariamente en el bosque. Huyen después de rellenar su piel con avispas para aparentar que se encuentra en pie. Durante su huida, los dioses castigan a los hermanos parricidas enviảndoles el fuego. Una vez calcinados ascendieron al cielo en forma del sol y la luna y fue asi como amaneció en el mundo. A continuación presento una versión de este relato, registrado en San Andrés Mixtla por Manuel Orea (1989), promotor cultural bilingüe.

"En aquel tiempo cuando no habia dia y ni noche, los dioses andaban en medio de las tinieblas, y fue cuando uno de ellos pensó en que tenía que haber una luz permanente sobre la tierra y para ello hicieron planteamientos entre ellos. La obra de los dioses no se materializó sino hasta después de un caso real de la 
humanidad que dice de la forma siguiente:

Durante esa misma época vivía un señor en el campo con su esposa y dos hijos; éste tenía una carabina con la cual cazaba todos los dias en el monte cercano a su cabaña, diariamente traia animales de diversas especies y variedades; su señora lo esperaba en la casa, y cuando llegaba, inmediatamente pelaban el animal para que en seguida la señora preparara un sabroso tekmole. Momentos después el cazador se sentaba rodeado de su familia y cuando sus dos hijos eran mayores de edad, el jefe de la familia enfermó y al poco tiempo murió. Los dos muchachitos, al ver muerto a su padre, sólo contemplaban con profunda tristeza la carabina, que se encontraba abandonada en un rincón de la casa. Ellos habian aprendido ya el manejo y mantenimiento del arma que por varios años representó el sustento de la familia, por eso un dia se dijeron:

- Agarraremos la carabina de nuestro padre e iremos al monte como lo hacia él y asi vamos a comer carne.

Asi lo hicieron, y cuando llegaron al monte mataron al primer animal, lo pelaron ahi mismo y llevaron sólo la carne, donde su mamá ya los esperaba con las tortillas calientes. Acostumbrada a recibir "carne de monte", a la señora no le costaba mucho trabajo guisar y en cuestión de poco tiempo preparó la comida. Los nuevos cazadores decian a su mamá:

- Come mamá, come con nosotros.

- Pero ella, rehusando la petición de sus hijos, les contestó:

- No hijos, yo tan pronto tenga lista la comida me iré, porque tengo que llevarle la comida a su padre y allá comeré con él, ahorita tendrá mucha hambre.

- Los muchachos se asombraron al oir las palabras de su mamá, puesto que sabian de antemano que su padre ya no existia; se hacian preguntas entre ellos sin obtener respuesta: "¿Dónde es que está nuestro padre si le vimos cuando murió?"

- Durante bastante tiempo ocurrió el incidente y por supuesto los muchachitos estaban intrigados porque su mamá diariamente salia diciéndoles que llevaba la comida a su padre. Al cabo de algún tiempo se dijeron: "ahora iremos detrás de mamá para espiarla y sabe dónde es que le da de comer a nuestro padre". Al poco rato los muchachos llegaban a la orilla de una arboleda, en el llano divisaron a dos que se andaban jalando, se fueron acercando más y más y a menudo se preguntaban: "¿quiénes serán aquellos?". Vieron en seguida que la mamá de ellos estaba desnuda y sobre ella se subia un venado, era uno de los más grandes, de aquellos denominados Istak Masatl (venado blanco). Después ambos se sentaron a comer lo que llevaba la señora.

- Los muchachos mientras tanto, permanecian sorprendidos por lo que habian visto, pero a menudo se preguntaban. "¿es aquel nuestro papá?, - No! Aquel tiene cuernos y es un venado. -Hermano probaremos suerte, lo mataremos para comerlo".

- Cuando la señora venía de regreso, sus hijos se escondieron nuevamente para que no los viera; enseguida salieron y se fueron a cazar otro animal; un poco más tarde llegaron a su casa trayendo carne, la mamá de ellos guisó lo que 
traian y enseguida comieron. Al dia siguiente se fueron nuevamente de caceria al monte acostumbrado; pero ahora con la intención de matar al que se decia papá de ellos, por lo que dejaron dicho a su madre que se esperara hasta que ellos regresaran con carne de monte para que le llevara una buena comida a su padre.

- De inmediato los hermanos salieron hacia el lugar donde ya sabian que estaba el venado a quien llamaron de la misma forma que lo hacia su madre: „No wewenton, xi mike no wewenton! (iven viejo mio, ven viejo mio!). Cuando el venado se presentó, uno de ellos le disparó con el arma y el animal cayó muerto. Al instante se abalanzaron sobre él, la abrieron la piel desde el pescuezo hasta la panza para quitarle la carne, dejándole la cabeza tal y como se encontraba antes de matarlo. Cuando tuvieron la piel ya sin came y sin patas, juntaron mucha paja para introducirla bien empacada dentro de la piel; también reunieron muchas avispas y jicotes y cosieron la piel de manera que el animal aparentaba estar vivo. Lo colocaron de pie sostenido por una estaca para engañar a su madre cuando viniera a buscarlo. Después se llevaron la carne a su casa y le pidieron a su madre que hiciera la comida.

- Cuando la mujer se fue al campo ellos huyeron sin rumbo llevándose la carabina. La mujer llegó al sitio acostumbrado y llamó al venado como lo habia hecho otras veces, pero como no salia optó por buscarlo, hasta que al fin lo vio parado en lugar y le dijo:

- "Ah. Estás enojado porque no venia pronto, pero no te preocupes que ya estoy aqui".

- En el momento en que decía ésto, lo abrazó pero se sorprendió cuando el animal se cayó, y más aún cuando las avispas salieron y la atacaron. La mujer se cayó y rodó mientras las avispas la picaban; ella maldecia a sus hijos. Por fin pudo levantarse y se dirigió a hablar con un sacerdote y le contó lo sucedido. Este les envió un castigo, puso en práctica su magia para enviar a los hermanos a la selva donde estarian a merced de las fieras y no regresarian nunca por haber matado a su propio padre. Internados en el bosque, los hermanos se tropezaban con animales fieros que amenazaban con devorarlos; para pasar la noche encendian una fogata y asi evitaban que los animales se acercaran. Un dia encontraron una roca grande y ahi se escondieron, pero unas aves llamadas "chachalacas" y "pepes" los andaban espiando y en seguida delataron el lugar donde estaban escondidos. Los dioses enseguida mandaron que la roca ardiera para que ahi murieran quemados y de ese modo empezara a haber luz en la tierra. Cuando sólo quedaron cenizas en aquel lugar, uno de los hermanos dijo:

- "Yo me llevaré las brazas y tú las cenizas".

- Cuando llegaron al cielo, la gente de la tierra se sorprendió al ver que ya había amanecido en el mundo. Como en ese tiempo todos los animales hablaban, las personas les preguntaban a ellos qué era lo que ocurria y por dónde saldrian el sol y la luna. Pero ellos negaban la información, por ello los dioses les pegaron la trompa y los animales enmudecieron para quedar hasta la fecha sin hablar. Cuando preguntaron al gallo, éste respondió:

- "Jesucristo saldrá allá abajo y se ocultará arriba". 
- Los dioses lo enmudecieron también pero le dieron oportunidad de que en su canto nombrara a Jescucristo.

- Se dice que el sol trae la lumbre que recogieron estos muchachos de la roca. Aquella viene contenida en doce espejos que trae el sol; cuando el sol despide sus rayos no destruye a la tierra porque enfrente viene Jesucristo para proteger al mundo entero de los efectos destructivos que pudiera contener el sol, o de lo contrario todos nos quemariamos en el primer momento. Se cree también que la luna está formada de pura ceniza y por eso su luz es más tenue. El sol y la luna son los dos hermanos, los cuales con el transcurrir del dia ponen de manifiesto cómo la humanidad pasa por la niñez, la juventud y la senectud. La niñez se observa cuando el sol viene saliendo por la mañana, cuando amanece; la juventud madura al llegar el mediodia; cuando la tarde va cayendo es que el sol va envejeciendo, y al caer la noche el sol ha muerto".

Este relato se refiere a tiempos primigenios en que no habia dia ni noche, los hombres vivian de la caza, y tanto los animales como los hombres estaban dotados de voz. La transformación del hombre en venado es un motivo recurrente en distintos mitos mesoamericanos; evidencia la presencia de concepciones arcaicas relacionadas con la caza, y la importancia de esta actividad para la subsistencia aún en los pueblos de agricultores. Nos remite a un complejo cultural en el cual parece también el motivo del nawalismo (el hombre que se transforma en venado). La aparición del sol, sincretizado con Jesucristo, significa el nacimiento del mundo y del orden que lo gobierna tal y como hoy lo conocemos: existen el dia y la noche, los animales y los hombres, la juventud y la vejez, la vida y la muerte que protagoniza el sol cada dia. En este mito el sol es el héroe civilizador.

El relato también recuerda el mito azteca del nacimiento del Quinto Sol, cuando los dioses se reunieron en Teotihuacan y decidieron crear al sol y la luna. Dos de ellos, Tecciztécatl y Nanahuatzin hicieron penitencia y se arrojaron al fuego. Tecciztécatl cuatro veces retrocedió ante las llamas, mientras que Nanahuatzin se arrojó sin vacilar. Los dioses se preguntaron de qué lado aparecerian los astros y decidieron que fuera en el Este y fue ahí donde se levantaron el sol y la luna, ambos con el mismo resplandor. Sin embargo, los dioses decidieron castigar a Tecciztécatl por su cobardia y uno de ellos lanzó un conejo sobre su faz, que era la de la luna, y desde entonces su luz se volvió tenue y se manchó con la figura de un conejo (Soustelle, 1983: 106-7).

En el relato anterior se presentan claramente los tres asuntos de la narración mitica, el esquema de la acción incoactiva señalado por López Austin (1990: 344): una narración de las hazañas, los temas nodales que abordan el orden de los procesos y los asuntos nomológicos que sustentan las leyes cósmicas. Encontramos también el proceso potencial de la aventura mitica que personifica a los seres no humanos, como los animales parlantes y el nacimiento y muerte del sol, asi como el vínculo entre distintas calidades de tiempo y espacio. Aparece 
el sincretismo entre muerte y resurreción del astro y la muerte y resurrección del dios cristiano, dando lugar a la conformación de la unidad entre Cristo y el Sol. Como señala Segre, al referirse a la Semana Santa en San Miguel Tzinacapan:

"El Cristo-sol, el metamorfismo del hombre-dios, es el encuentro entre el catolicismo y los elementos culturales de larga duración del pensamiento náhuatl, principio dual y transformación que han guiado el proceso aculturativo" (1987: 43).

Otros relatos semejantes en relación al nacimiento del sol y la luna han sido registrados en distintas regiones indigenas de México. Ichon (1973) recogió algunas variantes entre los totonacas de la Sierra Norte de Puebla. Williams García (1957) publicó una versión muy similar a la que he presentado, procedente del municipio de Astacinga (localizado también en la parte alta de la sierra de Zongolica). Un canto de extraordinaria dulzura que escuché por primera vez en San Juan Texhuacan en 1980, de la voz de una anciana mientras atizaba su fogón y que también consigna Williams en el texto referido, pareciera hacer alusión a la mujer que busca a su esposo transformado en venado:

\begin{tabular}{|c|c|}
\hline $\begin{array}{l}\text { "Masatl, masatl } \\
\text { kampa tihnemik } \\
\text { ni tlahko sakatl } \\
\text { choka nihnemik }\end{array}$ & $\begin{array}{l}\text { Venado, venado } \\
\text { donde estás } \\
\text { en medio del zacatal } \\
\text { me encuentro llorando }\end{array}$ \\
\hline $\begin{array}{l}\text { Masatl, masatl } \\
\text { Kampa tihnemik } \\
\text { Nika mo pompa } \\
\text { Ni choka nihnemik" }\end{array}$ & $\begin{array}{l}\text { Venado, venado } \\
\text { donde estás } \\
\text { aqui por ti } \\
\text { me encuentro llorando }\end{array}$ \\
\hline
\end{tabular}

Es de llamar la atención la continua referencia a cazadores y venados en los mitos y cuentos de los pueblos mesoamericanos lo cual si bien puede aludir a un sustrato preagricola, también recuerda que a lo largo del desarrollo histórico del área han coexistido las actividades relacionadas con la caza y la recolección con las labores propias de la agricultura.

Félix Báez-Jorge (1988: 215-216) refiere una versión muy parecida al relato señalado, misma que fue recogida por Bartolomé y Barabas entre los chatinos, grupo etnolingüistico que hoy en dia se asienta en la Costa Chica de Oaxaca. En el mismo texto se señala que Weitlaner obtuvo una narración semejante entre los cuicatecos, asentados en vecindad con los mazatecos. Estos datos apoyarian la idea de Aguirre Beltrán y Garcia de León, en el sentido de que la población de la sierra de Zongolica cuenta con un sustrato ligado a los mazatecos, sin embargo, aparentemente el nexo se extenderia también hacia otros grupos etnolingüísticos 
ahora ubicados más hacia el sur, tierra adentro de lo que hoy es el estado de Oaxaca.

El venado es una figura mesoamericana relacionada con Mixcóath, el dios de la caza. López Austin apunta que el venado o el maiz comestible es la combinación de Mixcoátl y Quilaztli, la diosa cuyo nombre se relaciona con la regeneración de la vida vegetal y humana (1994: 206-208). De modo que en el relato aludido se manifiestan motivos mesoamericanos relacionados con un sustrato cultural muy antiguo, los cuales expresan una relación estrecha con la vida de los cazadores, relación manifiesta seguramente, no sólo entre los mazatecos y los nahuas de la sierra de Zongolica, sino en otros pueblos ubicados dentro del área cultural mesoamericana.

Recordando la idea del desconcierto producido por el nacimiento del sol, en Tlaquilpa, pueblo vecino a Atlahuilco, se cuenta que existe una cueva hacia la que se enfila una hilera de rocas que parecen introducirse en la oquedad. Una anciana del lugar me narró lo que ahi sucedió: cuando el sol salió los hombres vivian en la oscuridad. Se les avisó que debian protegerse de la intensa luz, resguardándose en aquella cueva. No todos llegaron a tiempo y aquellos que no lograron entrar, quedaron ahi para siempre, convertidos en piedra.

Los nahuas equiparan a la superficie terrestre (Tlaltikpaktli), con el cuerpo humano: los rios son su sangre, las piedras sus huesos, la tierra es su carne, las plantas su vestido, algunas flores son sus adornos y se les compara con sus collares y sus aretes. López Austin estableció que el cuerpo humano ocupaba un lugar central en el pensamiento mesoamericano prehispánico; en éste, el cuerpo fue el principal referente cognocitivo para abarcar la universalidad de lo existente:

"En toda sociedad en la que el pensamiento mitico es predominante, existe la tendencia de equiparar los distintos órdenes taxonómicos y de homologar los distintos procesos, tanto naturales como sociales...Es el intento humano de alcanzar la gran sintesis clasificatoria...”. (1980: 171)

Otros investigadores han aplicado estas ideas en el examen del pensamiento religioso de distintos grupos étnicos no sólo de México, sino también de otras áreas culturales. Sandstrom (1998: 60-75) sostiene que los nahuas de la Huasteca Veracruzana tienen conceptos complicados del cuerpo que son fundamentales a su cosmologia y visión del mundo. Plantea que el cuerpo humano fue un "simbolo clave" para los antiguos nahuas y lo sigue siendo entre sus descendientes actuales. Como ejemplo del uso simbólico del cuerpo humano en el pensamiento nahua contemporáneo, ( $\mathrm{y}$ de manera semejante a las concepciones de los nahuas de Zongolica) el autor plantea que la tierra existe en forma humana, con su cabeza correspondiendo a las montañas, su cuerpo a la masa de la tierra y sus pies al inframundo. Asi mismo, la forma, la sustancia y la 
dinámica interna del cuerpo humano son idénticas a la estructura y las fuerzas que animan el universo.

Los nahuas consideran que se lastima a Tlaltikpaktli con las actividades propias de la agricultura, como la quema de su follaje y la horadación con la coa. Por ello, toda interacción humana sobre la superficie terrestre debe de ser antecedida por un ritual de xochitlali o "puesta de flores para la tierra", mediante el cual se invoca su permiso y su perdón por las acciones que la lastimarán al abrir un camino, cultivar una milpa o construir una casa. Antes de cultivar, después de la quema de la vegetación secundaria, se le pide que perdone el que se le haya arañado con el azadón, que se le haya quitado la ropa, que se le haya quemado su carne, puesto que su vestido, su follaje, será restituido con las nuevas plantas que crecerán. En esta concepción de la superficie terrestre la idea de la restitución es predominante: los nahuas se conciben como "huéspedes de la tierra", según la apropiada expresión de Alvarez (1991) cuando analiza el xochitlali en San Andrés Mixtla; sus acciones sobre ella obligan al agradecimiento:

"Le quemamos el pelo a la Tierra, que ya nomás se queda pelada. Se quedaron pura came, de ese cerrito pura piedra. Le quemaron la tierra y la hierba: su cuerpo"... "Es como si le cambiaran su vestido; es como ahorita ya rozaron y después quemaron y se queda pelado; luego le siembran y para el otro año ya tiene vestido... asi también la Tierra vuelve a vestirse para después ya nos dará de comer, por eso, entonces, asi como la siembra, asi ya es un vestido; como frijol, como maiz, como haba, quelites. Sembramos arriba de la Tierra entonces ya se viste". (cit. en Alvarez, 1991: 57).

Tlaltikpaktli proporciona el sustento a los hombres. Es la madre protectora de su salud y bienestar, madre nutricia que cuida y alimenta; la vida humana transcurre sobre su regazo. Es un ser sensible que sufre el transcurrir de los hombres sobre su superficie, quienes la lastiman, la ofenden, la horadan. En lenguaje reverencial se le pide la regeneración de los cultivos, la restitución de la salud de los individuos, el perdón por haberla ensuciado, lastimado u ofendido. Veamos un fragmento de una petición de restablecimiento de la salud de un enfermo de espanto:

"Tlaltikpak de mi alma, he venido a poner la flor; siempre va primero para poner una florecita. Un traguito te he ofrecido. Acaso es mucho, sólo es una copita. Hemos venido por mi hermano que aqui se quedó, aqui quedó tirado; te pido que lo perdones, ya sufrió bastante, ya pagó. El no vino a la tierra nomás unos dias, te suplico lo dejes vivir otro poquito, perdónale. Pedimos licencia para llevarlo a su casa. Tlalikpak de mi alma, Tlaltik Nonantzin y Tlaltik Notahtzin, Tlalokan Nana y Tlalokan Tata, voy a acompañar con agüita dulce..." (cit. en Alvarez, op. cit.: 106). 
La Tierra se invoca también en cada etapa del ciclo agrícola y en determinados momentos del ciclo vital del individuo. En el ritual para la siembra del maiz y en agradecimiento de la cosecha, se le ofrece tabaco, flores, aguardiente y comida, mientras se implora:

\author{
"Tú gran superficie terrestre, \\ no te enojes, \\ no te fastidies \\ aunque te hayan desvestido \\ aunque te hayan desnudado \\ aunque te hayan quitado tu ropaje, \\ aunque te hayan quemado tus huesos \\ aunque te hayan incendiado \\ aunque hayan quemado tu cuerpo; \\ pues con este Padre cultivo \\ Flor siete, \\ Con esta Madre cultivo Flor siete \\ Con él te cambiarán de ropaje; \\ Con él te cubrirán tu cuello..." (Orea, 1989: 18)
}

La vigencia del culto a la tierra remite a la cosmologia prehispánica y a la continuidad de antiguas prácticas ligadas al cultivo del maiz, asi como a los paralelismos simbólicos de las visiones del mundo que entraron en contacto. Sus campos funcionales cubren al conjunto de las instituciones fundamentales del grupo social: las actividades productivas, el ciclo vital y la cosmovisión (BáezJorge, 1988: 234)

Los nahuas conciben que existe otra vida que transcurre en el subsuelo, paralela a la que se desarrolla sobre Tlaltikpactli. Es aquella, El Tlalokan, el paraiso de los animales silvestres y de la fertilidad agricola, el depósito de todas las clases de riqueza, regida por una diferente dimensión espacio-temporal. Mantiene sus nexos con el exterior, con la superficie, mediante las cuevas, oquedades (que en la región se conocen como "sótanos"), ríos y arroyos subterráneos que abundan en la accidentada topografia de la sierra de Zongolica. En las zonas de transición, las cañadas exuberantes de verdor y humedad se encuentran saturadas de cuevas profundas, barrancas, sótanos peligrosos en los que a veces desaparecen perros de caza persiguiendo liebres o armadillos. Los hombres temen profundamente estas oquedades porque forman parte del Tlalocan o son sus puertas de entrada.

El Tlalokan se ubica pues en el subsuelo, donde habita una pareja de ancianos, Tlalokan Tata y Tlalokan Nana. Ellos son los dueños de la vida vegetal y humana que se desarrolla en Tlaltikpaktli, la superficie terrestre. En un relato que me fue narrado en el municipio de Texhuacan, se relaciona al señor del Tlalokan con el inicio de la vida agrícola. Este fue el primero en rozar la 
vegetación del bosque para sembrar maiz ayudado por un ejército de animales. Después de cosechar y guardar el producto en siete trojes, desapareció en una de ellas, llena de flores, donde se despidió con rumbo al Tlalokan:

"Debajo de la tierra hay otro mundo donde hay otros seres vivientes. Uno de aquellos seres era un pajarito colibri. Un dia por aqui estaba una muchacha a la que cuidaban mucho sus padres, se fue a lavar al rio y llegó un colibrí. La muchacha le dice:

-"me gustaria tenerte en mis manos, agarrarte".

El le contestó que era muy fácil porque en verdad no era un pájaro, sino un hombre.

- "tómame, envuélveme en tu seno y llévame".

Se lo llevó a su casa envuelto en un pañuelo, pero cuando llegó, su mamá se dio cuenta de que ya habia hecho compromiso:

-"oye tü ¿con quién estuviste hablando en el agua?".

-"con ninguno", respondió la muchacha.

- "hay de ti si no me vas a decir quién es"

Ya de noche el pajarito se convertia en hombre. Asi de noche era hombre y de dia pajarito. Pasaron meses hasta que un dia ella se sintio embarazada y le dijo al muchacho:

-"si lo saben mis padres me van a matar"

-"vamos a huimos", le dijo él.

" ¿pero cómo vamos a huir, si tenemos muchos guardianes? el tecajete, el temolote y la casa nos están vigilando".

- "toma un puñado de chile, tuéstalo, muélelo en el tecajete, embadúrnalo en las tablas, donde la casa tiene los ojos".

El muchacho le habló a la tuza y le dijo que hiciera un hoyo y los llevara al otro mundo. Cuando el papá y la mamá se dieron cuenta le preguntaron a los cuidadores si no habian visto por dónde se fueron, pero ellos les respondieron que no pudieron ver nada porque les dejaron tapados los ojos con el picante. Le dijeron:

- "la que ha de saber es la tuza".

La señora encontró a la tuza y le pidió que la llevara al Tlalokan. Ahi la señora encontró a la muchacha y le preguntó:

-“¿por qué te veniste para acá?”

- "Aqui vivo"

- "No, ahorita nos vamos"

- El padre de ella llevaba su machete porque la queria matar, le pegó a su hija en el vientre y se lo abrió y le sacó al niño, un varón, y lo aventó al agua. Ya después también avienta al agua a su hija.

- En eso una señora estaba lavando en la orilla del río y vió a la criatura flotando, la sacó del agua y se la llevó a su casa. Como a los tres meses el niño ya estaba grande. Creció muy rápido, empezó a platicar y después a trabajar. Un día le preguntó a la señora que lo había recogido:

- “"Tú eres mi mamá?

- - "No, yo te saqué del agua. Tu abuelito te aventó al agua y aventó también a tu 
mamá pero a ella se la comieron los peces".

- - "Ah, entonces asi es mi abuelito", dijo el muchacho.

- Después el muchacho siguió creciendo y un día le dijo a la señora:

- - "Ahorita voy a trabajar siete lomas, siete cerros"

- Y se fue a conseguir gente y que se consigue a quinientos trabajadores, pero eran puros animales. Y limpiaron las siete lomas. Entonces le dijo a su mamá:

- "Te voy a dejar en un lugar donde no vas a sufrir hambre, vas a tener de comer para toda la vida”.

- Sembró el maíz y lo cosechó. Hizo siete trojes y en la última de ellas se fue a sentar y la llenó de flores y le pasó el sahumerio. Después le dijo a la señora:

- "Ya me voy para el lugar donde es mi padre".

- Y en la última troje desapareció. El es el señor del Tlalokan, el que se convirtió en maiz".

El relato es una sintesis sincrética entre el mito mesoamericano del nacimiento de Huitzilopochtli a partir de la preñez de Coatlicue mediante una mota de algodón, y la concepción del dios cristiano por obra del Espiritu Santo. La mujer preñada por el hombre-colibri es la procreadora del Señor del Tlalokan, quien se convertirá en el maiz, el que da la vida y el sustento. El colibri que llegó del otro mundo, y fecundó a la mujer presenta el paralelismo con el Espiritu Santo en la concepción de Maria. El maiz, generador de vida, se asocia también con el dios cristiano que es padre e hijo al mismo tiempo, cuando éste dice que irá al lugar donde es su padre y se convierte en el señor del Tlalokan. Es desde entonces el dueño de los animales y el precursor de la vida agricola, sustento de los hombres y héroe civilizador. Al igual que en la tradición cristiana, el maiz se convierte en alimento sagrado y los hombres se alimentan del cuerpo y la sangre de su dios, quien es padre, hijo y espiritu.

El relato evidencia lo que planteara Propp: el mito pertenece a la esfera religiosa, pero cuando cambian las condiciones que lo originaron, pierde su sentido y funcionalidad y se convierte en cuento. Ello no implica necesariamente ausencia de una interpretación etiológica del entorno natural y social. (cit. en Segre, 1990: 46). En los relatos que he presentado se encuentran continuas referencias a los origenes, asi como a la evidente y vigorosa interrelación entre los distintos pueblos de tradición mesoamericana. Persiste la creencia en este ser sobrenatural, señor de la naturaleza, de las montañas y la vegetación, de los animales, de los rios y manantiales, quien cuida las riquezas y el equilibrio entre los elementos naturales. Este complejo mitico se conforma en torno a Tláloc, dios de la lluvia y los tlalokes, sus ayudantes; en él se relacionan los númenes del agua y de la tierra. Existen testimonios procedentes de diferentes horizontes culturales que hacen referencia a este complejo mitico; en ellos se alude a su labor en la custodia de los lugares sagrados y en resguardo de un mal uso de la naturaleza y sus recursos (Anzures, 1990).

Esta idea remite, según López Austin (1980: 64) a la originaria división entre 
cielo y tierra, según la cual el mundo inferior daba origen a los rios y depósitos de agua; se imaginaba a este mundo terrestre y acuático custodiado celosamente por los "dueños" de manantiales y de bosques. Los montes fueron personalizados como dioses vinculados con las lluvias de quienes emanaba el agua; el dueño de la montaña arquetípica, Tlalokan Tekuhtli tenia a su servicio a los cuatro grandes tlaloke quienes residian en cada uno de los extremos del mundo y eran a su vez apoyados por un ejercito de tlaloke o tlamacazke menores.

En la sierra de Zongolica se dice que en el Tlalokan habitan todas las especies de animales silvestres y de vegetales que se encuentran en la superficie, pero en un ambiente de opulencia y armonia, puesto que los animales se encuentran libres, los árboles de frutas y las plantas de maiz rebosan hermosos productos y las corrientes y fuentes de agua permanecen limpias y abundantes. Garcia de León (1969: 294-299) encuentra entre los nahuas del sur de Veracruz, a este Dueño de los Animales cuyo dominio se restringe a los animales silvestres, aquellos susceptibles de ser cazados o pescados por el hombre, por lo que plantea que posiblemente se relaciona con alguna deidad preagricola que rige únicamente la caza y la pesca. Ubica al Tlalogan del sur de Veracruz como el concepto prehispánico acerca del Tlalokan, pero asignado a un lugar geográfico determinado: el mundo subterráneo de la serrania de los Tuxtla. Aramoni (1990: 145) señala que para los nahuas de Cuetzalan, el Talokan es fuente inagotable de riquezas, un lugar limpido y puro que contrasta con la corruptibilidad de Taltikpak, la superficie terrestre. Ahi habitan los seres humanos que vendrán al mundo y todas las especies de animales, cuyo dueño es San Lucas

Para los nahuas de la sierra de Zongolica el señor del Tlalokan es también el dueño de los animales silvestres. En un relato muy difundido en toda la región, se dice que un cazador fue llevado accidentalmente al subsuelo, mientras perseguia una presa de caza, y ahi encontró todos los animales que alguna vez había herido o matado con su arma. En su afán por capturar a la presa, cayó en una cueva o "sótano", donde se encontró con ese ambiente agradable y exuberante, pero sólo para ser reprendido por el señor del Tlalokan, quien lo obligó a curar con la misma planta con que su mujer cocinaba la carne de monte, a todos los animales que había lastimado a lo largo de su vida. El cazador transcurre siete dias en el subsuelo tratando de acatar lo dispuesto, pero al volver a su espacio habitual encuentra que en la dimensión temporal de la superficie terrestre, las horas equivalen a dias y los dias transcurridos fueron en realidad años.

Para los nahuas, evidentemente, las cuevas son el punto de entrada al otro mundo, es por ello común que en esta transición se de una transformación de las dimensiones temporales y de los atributos de los personajes. En algunas versiones, el castigo principal para este cazador que se olvidó de pedir permiso a los Señores del Tlalokan y que lastimó a tantos animales, radica en el hecho de que su vida ya no será la misma; con el paso de los años todo ha cambiado, los 
hijos se han ido, su mujer y amigos han fallecido, ya no cuenta con casa, ni familia, ni tierra para cultivar. A continuación presento una versión de este relato procedente del municipio de Atlahuilco, en el cual es la mujer quien recibe el castigo de convertirse en un venado por no haber esperado pacientemente el regreso de su esposo. ${ }^{2}$

"Habia un señor al que le gustaba mucho cazar, principalmente a los conejos. Cierto dia que fue de caza le ocurrió algo: vió un conejo y al momento le disparó, pero la bala no consiguió matarlo, únicamente herirlo, lo que ayudó al conejo a correr y meterse a una cueva; pero por desgracia fue visto por el cazador que en seguida corrió tras él. Al entrar a la cueva el cazador se encontró con un señor y le preguntó:

- “No vió usted si aqui fue donde se metió un conejo herido?”. El señor le contestó.

- "Sí, aqui se metió ese animalito que tú buscas, y aqui se encuentran todos los demás que tú has lastimado".

El cazador se espantó, y le preguntó quién era él. El señor le contestó:

- "Soy el que se encarga de cuidar todo lo que hay sobre la tierra".

- Entonces el cazador le preguntó:

- "¿Tú eres el Tlalokan?"

- El señor le contestó:

- "Si, por eso quiero que cures a todos esos animales que tú has matado, pues ellos están aqui; ven quiero enseñártelos". El Tlalokan llevó al cazador y éste vió que sobre unas camas de piedras estaban echados muchos conejos, algunos de ellos gritaban de dolor, otros lloraban, entonces el cazador le dijo al Tlalokan:

- "Pero no sé cómo curarlos".

- El Tlalokan le respondió:

- "Pero sabes cómo te los preparaban cuando te los comías. El cazador respondiō":

- "Mi esposa es la que sabe con qué condimento se preparan, pues creo que les pone una hoja para que tengan buen sabor".

- Entonces el Tlalokan mandó al cazador al monte a que buscara esa hoja, pero el cazador por más vueltas que daba al monte no encontraba esa hoja. De pronto se dio cuenta que venia bajando del monte una anciana, y ésta le preguntó al cazador:

- "¿Qué buscas muchacho?"

- El cazador le contestó:

- "Mi patrón me dijo que yo lastimé a sus conejos; ahora quiere que los cure, por eso me mandó aqui, para que buscara las hojas con que mi mujer los prepara cada vez que yo mato uno".

- Entonces la anciana le contestó:

- "Ah, pues eso es fácil, por ahí donde pasaste está un árbol, ve y corta unas

Esta versión fue recogida por Isabel Ixmatlahua, promotora bilinguie de la Dirección General de Culturas Populares; se encuentra impresa en la publicación Tlatolli, de la Unidad Regional del Centro de Veracruz, 1988. 
hojas de ese árbol cuando llegues a la cueva, a cada conejo le pegas y verás que se va a aliviar".

- El cazador regresó a la cueva e hizo lo que le indicó la anciana quedando sorprendido al ver que a cada animal que le iba pegando volvia a levantarse para caminar como si nada hubiera pasado. Después de que terminó le preguntó al Tlalokan que si ya se podia ir para su casa, pero el Tlalokan le contestó:

- "Tú te quedarás a trabajar durante siete días, al término de éstos te irás".

- El cazador aceptó sin saber que dentro de la cueva no eran como él conocía las guias de calabaza, pues ahi estaban representando como viboras. Cuando terminó de separarlas lo mandó a que fuera a limpiar su milpa, pues el Tlalokan tenia dos parcelas sembradas; en una ya se estaba secando la mazorca y en la otra aün habia elotes. El Tlalokan no hacia otra actividad que no fuera la de cuidar todo lo que habia en la tierra. Una tarde le dijo al cazador que si queria, que fuera a cortar unos elotes, pero únicamente que cortara dos o tres elotes pero él pensó que esos no le alcanzarian para los dos y cortó más. Regresó a la cueva, hizo lumbre y los puso a hervir; pero cuando éstos empezaron a multiplicar provocando que se empezaran a salir de la olla, entonces el cazador se espantó y llamó al Tlalokan y éste le dijo:

- - "Ya ves lo que te sucede por haberme desobedecido, yo te habia dicho que con sólo dos que pusieras serian suficientes pues se multiplicarian; y asi cuando regresaras a tu casa, con sólo dos maices que pusieras en una olla para preparar el nixtamal seria suficiente". El Tlalokan fue por un toro, lo amarró en el poste y e dijo al cazador:

- "Mientras te comes tus elotes cuidas a este animal, no lo vayas a soltar". El cazador se quedó cuidando al animal, al ver que éste empezó a mugir, al cazador le dio lástima y lo soltó. El animal inmediatamente se fue al lugar donde la milpa aún está verde y empezó a tumbarla. En ese momento llegó el

Tlalokan dándose cuenta de lo que estaba haciendo el animal, ésto hizo que se enojara más con el cazador y entonces le dijo:

- "Ahora ya te puedes ir a tu casa, pero cuando tú llegues ya no te reconocerán, pues mientras aqui han transcurrido siete dias, allá donde tú tienes a tu esposa han transcurrido siete años y tu esposa te cree muerto. Ella ha decidido casarse y cuando tú llegues se hará la boda, pero yo te diré qué hacer. Ahora quiero que me digas lo que quieres como pago, pues si te doy dinero te lo acabarás rápido; en cambio, si te doy semillas no, pues podrás sembrarlas; venderás las que te sobren y esas nunca se te acabarán.

- Por fin llegó el día en que tendría que regresar a su casa, el Tlalokan le dio lo que le prometió y se fue. Al llegar a su casa se paró en la puerta y desde ahi vio mucha gente. Cuando empezaron a tocar los músicos salieron a bailar los novios. En ese momento él se fue hacia la pareja pero no lo reconocieron, entonces él tomó a la novia y la metió en su canasta, ella brincó y al caer al suelo y levantarse ya estaba convertida en temazate (venado) que salió corriendo porque los perros se fueron sobre ella". 
En este relato se aborda nuevamente la transición de la vida de cazadores hacia la de campesinos cultivadores de maiz. La llegada al Tlalokan se presenta como el castigo para un hombre que resuelve su sustento mediante la caceria. Es en este sitio donde se gesta la aparición del maiz, grano que se reproduce y será la semilla que fecundará la tierra y proporcionará una nueva fuente de alimentos. La mujer que se convierte en venado, al final del relato, como exponiéndose a ser presa de caza, recordaria el vinculo existente en el pensamiento mágico mesoamericano entre Mixcoatl, el dios tribal de las antiguas bandas cazadoras recolectoras y Mázatl, venado. (Aguirre Beltrán, 1986: 69). López Austin apunta que el venado es la combinación de Mixcoatl y Quilaztli la diosa que tenia bajo su dominio tanto el retorno de la vegetación como la generación humana, puesto que ayudó a Quetzalcoatl en la preparación de la mezcla que daria nacimiento a los hombres. La fusión de Mixcoatl y Quilaztli da lugar al alimento; según este autor, en distintas fuentes Quilaztli aparece como el venado de Mixcoatl (1994: 205-209).

El señor del Tlalokan es la principal deidad del Tlalokan como ámbito espacial, pero se concibe en el seno de una jerarquia donde él es "el mero jefe", seguido de su contraparte femenina (Tlalokan Nana). Alvarez (op. cit.: 112) menciona que en San Andrés Mixtla también se invoca a una pareja de jóvenes llamados Tlalokan Chokotzi (muchacho) y Tlalokan Takotzi (muchacha). Según Garcia (s/a: 356) en Texhuacan se invoca a Totlaltihpaknatzi (abuelita de la tierra), Totlaltihpaktahtzi (abuelito de la tierra), Tlalokan tío, Tlalokan sobrino, Tlalokan hermano y Tlalokan cuñado.

Los Señores del Tlalokan se rigen por necesidades similares a las de los humanos; asi como se encuentran en un ámbito jerarquizado conforme a los patrones domésticos de los nahuas, también requieren de los alimentos y bebidas que se les ofrendan. El vapor o la neblina que en ocasiones parece emanar del suelo, significa que en el Tlalokan están haciendo tortillas y es el humo que se desprende del fogón. Asi mismo, en el ritual de xochitlali (ofrenda de flores para la tierra dirigido ya sea a solicitar permiso, pedir perdón, implorar o agradecer), se vierte el café y el aguardiente sobre la superficie de la tierra y se entierran los alimentos (casi siempre tortillas y mole de gallina) para que los Señores del Tlalokan puedan consumirlos.

En Texhuacan, donde se considera que la familia del Tlalokan consta de siete miembros, se ofrecen siete platos con comida, siete tamales agrios, catorce tortillas, una botella de Tequila, una de pulque, una de kaxtila (bebida de caña fermentada), dos cervezas y dos tazas de café para la pareja de mayor edad y jerarquia. El oficiante conversa con todos los que reciben estas viandas, esperando varios minutos mientras comen y les plantea sus peticiones, después de lo cual se cubre todo con tierra, cuidando que ninguna persona o animal tome algo de estas ofrendas, lo que causaria severos enojos de los señores del Tlalokan. (Garcia op. cit.: 365) 
Es frecuente escuchar testimonios en que las personas narran haber visto en sueños al Señor del Tlalokan, quien les proporciona instrucciones acerca de procedimientos curativos, conocimientos reservados en torno a técnicas de adivinación, cualidades de plantas y animales, consejos en relación a algún asunto especifico, e incluso reclamos por no haberle invitado una copa de aguardiente antes de iniciar una siembra o la construcción de una casa.

Seducidos por las riquezas y tesoros que existen en las cuevas, algunos hombres se aventuran a éstas, provocando el disgusto de los Señores del Tlalokan, quienes impiden su regreso a la superficie. Los castigos, sin embargo, pueden evitarse si se efectúan los rituales prescritos. Hace algunos años, en un paraje de Atlahuilco, dos hombres murieron en un intento por introducirse en uno de estos los "sótanos" o profundas oquedades que existen en la sierra. Algunas versiones dicen que perseguian una liebre e intentaron capturar el animal alumbrándose con trozos de ocote encendido, muriendo después por intoxicación o asfixia. Dos mujeres del poblado de Zacamilola, enviudaron a causa de ese accidente; solas y en la miseria, me relataron que sus maridos fueron invitados por un hombre acaudalado de la región que los convenció de que se introdujeran prometiéndoles que encontrarian riquezas. De cualquier modo la gente reaccionó con profundo temor; se realizaron durante varios dias una serie de ofrendas y rituales dirigidos a e los Señores del Tlalokan.

Se dice también que los Señores del Tlalokan han castigado con la muerte a más de un miembro de expediciones de paleontólogos que han incursionado en la zona para explorar cuevas, barrancas y pronunciadas pendientes. Según los nahuas, han cometido el error de adentrarse en sus dominios sin seguir los procedimientos rituales indispensables.

El Tlalokan es también el sitio de donde los tepahtikeme (médicos y especialistas rituales) han adquirido su sabiduria y sus poderes. Báez Galván (1997) refiere que un reconocido tepahtiketl de Zacamilola le relató cómo adquirió su capacidad para curar a través de un árbol que emergió de debajo de la tierra y lo obligó a rescatar a un animal que cayó en una barranca; de este modo fue llevado al Tlalokan, donde recibió sus poderes escuchando voces del árbol y del animal que había rescatado. En este relato es evidente que el árbol referido por el tepahtiketl es el Xochinkuauit, el árbol florido de Tamoanchan que Aramoni relaciona con el corazón del Tlalokan entre los nahuas de la sierra Norte de Puebla.

Los nahuas de Zongolica conciben que existe otro estrato subterráneo, inferior al Tlalokan, el Miktlan, donde habita el Tekuane, ${ }^{3}$ personaje maligno que también puede causar susto y con ello la pérdida del tonal, entidad anímica de

\footnotetext{
3 Tequani, según Simeón (1988, 508) significa animal salvaje, venenoso, persona malvada, cruel, devoradora de hombres.
} 
la persona, fundamental en la concepción nahua. El tekuane se aparece de forma intempestiva; y se sirve también del kokolisehekatl (viento enfermo) para trastornar la integridad de los individuos. Habita en los lugares obscuros y desolados, en la oscuridad nocturna, y se sirve de sus ayudantes, los chikome, seres de siete colas con cuerpo de gato y de zorrillo, que atacan durante la noche produciendo rasguños o heridas a sus victimas. "Los chikome son como los topiles del tekuane", según las palabras de una conocida especialista ritual de Atlahuilco.

Existe también un conjunto de deidades que son quienes resguardan las entradas y puntos de transición al ámbito frío, húmedo e inferior del Tlalokan. Los cerros, los animales silvestres, los manantiales, las cuevas, el bosque y los "acahuales" (terrenos cubiertos de vegetación secundaria) son propiedad de parejas de "dueños" (una entidad masculina y su contraparte femenina), quienes esperan de los humanos un comportamiento ritual que les posibilite acceder a sus beneficios. Estos seres sobrenaturales son imaginados como una réplica de la pareja humana, cuyos hijos son, según el caso, los animales del monte, o las plantas cultivadas, o los manantiales de agua. La integridad individual de cada ser humano depende en gran medida, de no transgredir la normatividad ritual relacionada con estas entidades. Se trata de una especie de divinidades secundarias especializadas en los distintos elementos.

Ichon ubica a esta clase de divinidades entre los totonacos en la categoria de dueños, y considera que se ubican en la jerarquia inferior de las divinidades totonacas, dado que resultan ser intermediarias entre las divinidades principales y los hombres. (Ichon, 1973: 102-104). Según López Austin, en la cosmovisión mesoamericana la aparición de los dioses como parejas de conyuges es también una proyección de la concepción cósmica dual (1980: 61). Esta originaria división dual de cielo y tierra que asignaba a la parte inferior los lugares de procedencia de las riquezas y de las lluvias, estaba custodiada como hoy, por los dueños de manantiales y bosques.

Signori y Lupo, en su investigación en la Sierra Norte de Puebla, ubicaron a los dueños de lugares especiales en la categoria de ehekame (aires o vientos) (1989: 83). Posiblemente los "dueños" de lugares se transformaron en espiritus con efectos dañinos sobre las personas, influidos por la concepción europea del "mal aire". En la sierra de Zongolica, al transitar por lugares que se consideran bajo su dominio como los cerros, los manantiales o el bosque, se encuentran en ocasiones estas esencias que hablan a las personas, las tocan o se les aparecen en formas diversas para desvanecerse de inmediato, provocando enfermedad de "mal aire". El afectado deberá ser tratado por un especialista, mediante un procedimiento terapeútico dirigido a desprender o exorcizar del cuerpo las esencias dañinas.

Es por ello inusual encontrar personas caminando solas por lugares que se 
consideren bajo el cuidado de alguno de estos "dueños". Al acercarse a beber o captar agua de un manantial o caminar por el bosque solitario, se corre también el peligro de ser tocado por estas esencias. Los ehekame pertenecen a la categoria de los espiritus, generalmente hostiles a los hombres. En otras ocasiones sus efectos dañinos pueden ser de mayor trascendencia si ocasionan un "susto", lo cual implica la pérdida temporal de una de las entidades energéticas del hombre, el tonal. En este caso el procedimiento de cura es contrario al de la limpia que consiste en el exorcismo del "mal aire", mientras que en ocasión del "susto" el procedimiento consecuente es de adorcismo, de incorporación al cuerpo de la entidad perdida. El "mal aire" ocupa el lugar que el tonal dejo vacio dentro del organismo del individuo, y es causa de enfermedad debido a la pérdida de los principios energéticos. (Segre, comunicación personal).

Dentro de la categoria de los ehekame, se ubican las esencias malignas, de naturaleza fria que desprenden los difuntos. Después de haber permanecido en contacto con un difunto o cerca de él, las personas se impregnan de esta esencia llamada "mal aire" (kokolisehekatl, viento enfermo, o amo cuale ehekath, aire no bueno), misma que puede ser contagiada a otros si no se efectúan una serie de procedimientos de "limpia" con humo de copal o de chile, y yerbas aromáticas de uso terapeútico como el sauco y el romero. Después de haberse realizado las exequias en un hogar donde se presentó un deceso, los familiares barren con sumo cuidado los restos de las flores, incienso y ceniza y las entierran en un extremo del solar doméstico para evitar que el "mal aire" que aún conservan continue contaminando a sus moradores.

El amo cuale ehekatl también logra transmitirse mediante actos de brujeria o tlahchihuilistli, enterrando en el cementerio prendas de ropa que haya usado la persona a la cual se desea provocar un daño, ya que se considera que los seres humanos desprenden una esencia que se adhiere a su ropa y puede ser manipulada con la finalidad de dañar o beneficiar a su poseedor. Pero el "mal aire" también puede ser una "ánima en pena", el espiritu de un difunto que transita por cruces de caminos o veredas apartadas, donde se aparece en forma humana para desvanecerse rápidamente.

$\mathrm{El}$ "mal aire" se introduce en el interior del individuo, como un viento suave que entra por la nariz, y le provoca malestares y enfermedad. Son especialmente vulnerables los niños, los enfermos, las mujeres encintas (ya que el producto puede resultar afectado), las personas de naturaleza "débil" y quienes tienen una herida o llaga al descubierto. Tampoco es conveniente salir del hogar antes del amanecer con el estomago vacio, puesto que entonces el "mal aire" puede entrar con mayor facilidad en el organismo del individuo; se recomienda protegerse de sus efectos realizando el ihtitsakuas o "cierre de estómago", que consiste en ingerir algún alimento antes de salir. (Chimalhua et. al. 1989: 14).

El término amo kuali ehekatl se refiere al mal en un sentido amplio; como 
señalan Signorini y Lupo (op. cit.: 82-83) en este concepto se incluye también al demonio cristiano integrado en la cosmologia nahua, aunque con una identidad aproximada, y cuyo poder se extiende sobre el mundo, pero con una capacidad inferior a la de los santos y Jesucristo. Benito Chimalhua (ibid.), originario del municipio de Zongolica, enlista los lugares en los cuales se puede adquirir el "mal aire": los cruces de caminos, los caminos de herradura, los cementerios y los funerales. Agrega que el "mal aire" se encuentra principalmente a las doce del día, a las siete de la noche y a la media noche, es decir, en los umbrales entre la mañana y la tarde, entre la tarde y la noche y entre el fin de un día y el inicio de otro.

En el pensamiento prehispánico, cada hora del dia tenia características determinadas, ya se tratase de un momento diurno o nocturno, de acuerdo a la influencia de su signo y su numeral en el calendario y por la secuencia de otros ciclos, que hacian de todo momento una combinación de las influencias provenientes de los cielos o del inframundo. Las representaciones referentes a los momentos y puntos de contacto entre el tiempo y el espacio servian de fundamento a la actividad ritual, puesto que la vida de los hombres y de todos los seres vivos se encontraba pemanentemente influida por la intervención de fuerzas sobrenaturales favorables o perjudiciales. (López Austin, 1980: 72-74).

En los cerros y montañas de la sierra de Zongolica, reside el Tepeyolohtzintli, el corazón del cerro, donde según Reyes (1990: 23) se encuentran los niños que murieron sin haber sido bautizados, asi como quienes murieron ahogados en los ríos o victimas de un rayo; llevan un agujero en la cabeza y se denominan kokoyomeh, (los hijos menores) o tlahtlatzinihteh (tronadores). Ellos se encargan de limpiar los cauces subterráneos y de atraer la lluvia. Aramoni (op. cit.: 146) registró en Cuetzalan la existencia también de Tepeyolo o Tepeyolojti, dueño del "tesoro del cerro". López Austin (op. cit.: 64) señala que en tiempos prehispánicos, emanaban de los montes el agua y las malas influencias causantes de enfermedades o daños a las cosechas. Ahi residia el Tlalokan Tecuhtli, dueño de la montaña arquetípica, seguido por una jerarquía de tlaloke, moradores de cada uno de los extremos del mundo y los tlamacazke menores, encargados de los distintos tipos de precipitaciones y meteoros.

En Atlahuilco se conoce como tlalokes a los dueños del agua; éstos son capaces de provocar el amamahtli o susto de agua. Los cuidadores de los cerros se llaman xochiwa; son hombres o mujeres que por las noches se despojan de sus piernas y se colocan dos tizones o leños encendidos. Vuelan de uno a otro cerro cuidando los tesoros que éstos encierran y aparecen como bolas de fuego que se desplazan velozmente. Los xiwime, en cambio son los ladrones de los cerros, y los xochiwa son los encargados de combatirlos; a cambio de ello, Tepeyolohtzintli, el Señor del Cerro les entrega dinero como pago por sus servicios. 
Algunas personas pueden ser identificadas como xochiwa o como xiwitl debido a que han acumulado cierta riqueza, misma que pudieron haber robado de los cerros o recibido como pago por ser cuidadores. Las versiones varian en cuanto a las funciones de estos seres; en algunos puntos de la Sierra se identifica a ambos como cuidadores de los cerros, mientras que en otros, como en Atlahuilco sólo existen los xiwime, hombres o mujeres de naturaleza benéfica que transformados en bolas de fuego cuidan de los cerros durante la noche. Son ellos los responsables de la existencia de los "sótanos", oquedades que son huella de su paso veloz por la superficie terrestre. Estos personajes pueden ser identificados en la vida diurna y cotidiana por el cabello: los hombres son calvos, mientras que las mujeres lo llevan largo hasta los tobillos. Esta figura recuerda imágenes medievales europeas: las brujas del viejo continente que también se convertian en bolas de fuego, se transforman en mazaka en la sierra norte de Puebla (Aramoni, op.cit: 137; Segre, 1990: 55) y en xiwime en la sierra de Zongolica. Se trata de personajes que logran su metamorfosis despojándose de sus piernas, mientras su cónyuge reposa en plácido sueño nocturno.

Luis Reyes (ibid.) registró en la sierra de Zongolica la existencia de un ser antropomorfo, sin articulaciones y con los pies volteados hacia atrás que habita en la selva y la montaña, llamado kohsalvaje (salvaje del bosque) y que en algunos casos es considerado el dueño de los venados. Asi mismo, señala la presencia de el molok, leoncillo habitante de las montañas que cuida de los montes.

Garcia (op. cit.: 353-354) menciona la existencia del Anciano del Temazcal, el Wewetemazkalli, cuyo cuerpo se encuentra delineado por las piedras que se introducen al interior del baño de vapor. Es concebido como un enano que duerme en el interior de la pequeña edificación, quien despierta cuando la comadrona realiza un ritual dirigido a solicitar su permiso antes de bañar a una parturienta. Según Garcia se considera a este personaje de mal carácter, capaz de causar graves trastornos a la salud de quienes entran a él con fines de restablecimiento fisico o de purificación, o bien si se permite que se posen animales ponzoñosos en las piedras del interior. Su enojo puede ser la causa de enfermedades como el edema (posawalis), cansancio (otlawalis) o dermatitis (sawayomeh); el Wewetemazkalli puede incluso provocar la muerte de aquel que le causó un disgusto. Cuando el tepahtiketl diagnostica que la enfermedad proviene del enojo del Wewetemazkalli, procede a realizar un ritual de puesta de flores (xochitlali) dentro del pequeño recinto. García registró una bella oración que se dirige a este personaje en forma de regaño:

"Aqui vine temazkalli de piedra. Eres piedra, no santo. ¿Quién eres tü? Aqui vine, te estoy llamando. isuelta a tu nieta! ¿qué quieres? La estás agarrando. Mira, señora, eres mujer, eres curandera. No vayas a pensar que eres hecha para el mal. Asi te llaman. Ahora te estoy curando. ceres hombre, mujer? Te ocuparon para curar. Asi es como te llaman, eres piedra, no dios" 
(p. 354).

"Nikan oniwala temaskaltetl. Titetl, mach tisanto. ¿Akinin teh? Oniwala, nimitznotza. ¡Xikahkawa moxwi! ¿Tlan tikneki? Omitztlakehkeh titepahti iwan axan titlawiteki. ;Xikahkawa! ¿Tlan tikneki? Tikitzkihtok. Xikita, nanita, teh titena, titepahti. Amo xikihto titetlakewal. Inkon ik mitznotza. Axkan mitztepahchiwa. ¿Titeta, titena? Omitztlakehkeh titepahtis. Mitztlakewa titepahtis. Ihkon ik mitznotza. Titetl, mach tidios”. (p. 353)

En la oración se observa el carácter bisexual de esta deidad, aunque en la religión prehispánica el baño de vapor estaba bajo la protección de una anciana, Temazkaltesi, la abuela del baño de vapor, ahora parece predominar, al menos en la denominación, un carácter masculino. Ichon (op. cit.), asocia el dueño del temazcal de los totonacas con Huehueteotl, el antiguo dios del fuego.

Los Nawahka Tatameh son los señores de los cuatro rumbos, ayudan a que la milpa crezca, pero en ocasiones destruyen los sembradios con tormentas o vientos fuertes; existe también Acawahka, el Señor del Acahual (la vegetación secundaria de los terrenos que alguna vez han sido desmontados por el hombre), quien se esconde en los lugares de extrema maleza y reclama también un ritual antes del desmonte.

Del mismo modo que los nahuas perciben las esencias de los seres que han fallecido, también establecen que los vegetales y minerales poseen vida y alma sensitiva. Todas las cosas tienen ekawil, es decir, una especie de aura que rodea a las personas y a las cosas, contraparte del tonal, el cual se encuentra en el interior de los individuos. Los hombres, los vegetales y los animales tienen tonal y ekawil, los minerales sólo poseen ekawil.

Otro aspecto que me gustaria señalar es el principio de pensamiento analógico que se expresa en la cosmovisión nahua. Asi como se encuentra una analogia entre la superficie terrestre y el cuerpo humano, en una gran variedad de situaciones se aplica este principio. Por ejemplo, una mujer embarazada no debe ingerir alimentos que hayan quedado pegados en el fondo del recipiente porque ello puede provocar que en el momento del parto la placenta quede adherida en el fondo de la matriz. La placenta se coloca dentro de una vasija de barro antes de ser enterrada, puesto que si se coloca directamente en la tierra su putrefacción puede provocar la muerte del recién nacido, ya que equivale al enterramiento de su propio cuerpo. Si el bebé enferma se supone que es a causa de que su placenta presenta signos de descomposición, de manera que es necesario desenterrarla, limpiarla, asarla y envolverla en plástico para que se conserve en buen estado en algún punto seco de la casa. (Garcia, op. cit.: 97 98)

El fuego del hogar doméstico tiene vida propia, en ocasiones se niega a producir 
el calor necesario para preparar las tortillas, o los platillos ceremoniales como las distintas clases de tamales y moles. Es sensible a los estados de ánimo de las cocineras; si alguna de ellas siente disgusto, los alimentos no percibirán el efecto del calor y por lo tanto quedarán crudos. Las mujeres que pasan mucho tiempo junto al fuego pueden ser "jaladas por la lumbre", es decir, su tonal puede quedar atrapado por el fuego y por ende, se requerirá realizar el ritual de tonaltzatzilis, que consiste en gritarle al tonal para hacerlo volver al cuerpo de la persona afectada.

El fogón se considera una entidad animada que posibilita la continuidad de la vida al procurar la preparación de los alimentos, y que recuerda la veneración a Huehueteotl o Xiuhtecutli, el antiguo dios del fuego. Es el referente principal de la vida doméstica y de la reproducción de los roles y relaciones entre los géneros y entre las generaciones. Cuando una pareja decide escindirse de la familia extendida para residir como familia nuclear por lo menos durante una etapa de su ciclo de desarrollo, plantea que ha llegado el momento de "hacer nuestra lumbre aparte", alrededor de ella se iniciará otra etapa de su vida y un nuevo centro de energia y calor para sustentar la reproducción vital y la rutina doméstica. Para los nahuas, un hogar sin fuego es sinónimo de pobreza, descuido y abandono; una mujer hacendosa, buena esposa y buena madre mantendrá encendido el fogón desde antes del amanecer; durante la noche dejará brazas encendidas, aprovechando su calor para el lento cocimiento del maiz para las tortillas del siguiente día.

Puede suceder también que algunos platillos o ingredientes, como los frijoles o los tamales que se preparan para un día de fiesta, se nieguen a cocerse, en respuesta a disgustos entre los miembros de la casa; en tal caso, la cocinera debe colocar en el fuego siete chiles serranos al mismo tiempo que le habla a los alimentos (Chimalhua e Ixmatlahua, 1988: 15).

\section{b) Entidades que conforman a la persona.}

Para los nahuas de la sierra de Zongolica la persona humana está compuesta del noyahko el cuerpo o la carne, el tonal, elemento interno que resguarda la integridad del individuo, el ekawil, que se concibe como la forma externa del tonal y por lo tanto como parte de éste, el yolo, entidad que se asocia con los estados de ánimo como tristeza o angustia y el ihiyoth entidad donde se concentran las pasiones y los malos sentimientos. Alvarez (op. cit.) plantea que existe en San Andrés Mixtla un padecimiento reconocido con el término yolkokolistli (de yolo corazón, kokolistli, enfermedad) que sus informantes traducen como tristeza. Es usual escuchar en forma de saludo la frase " ¿cómo está su corazón? (¿tlen siktowa moyolotzin?)". Garcia (op.cit.: 455) traduce el padecimiento de yolkokolistli como tiricia o tristeza, y señala que se presenta debido a la ausencia del ser amado. El tratamiento para curar esta enfermedad consiste en la realización de una limpia con siete claveles rojos, los cuales deben 
ser lanzados después, dando la espalda, en alguna corriente de agua cercana al hogar del enfermo. En este sentido, para los nahuas como para los tzeltales de Cancúc, las emociones se describen como estado del corazón (Pitarch, 1996: 87).

El tonal es la entidad que concentra la energia en el seno del organismo de todo ser humano. Su pérdida conduce al debilitamiento fisico del individuo y puede ocasionar su muerte. Para los antiguos nahuas, según López Austin, el tonalli era una fuerza que determinaba el grado del valor animico del individuo, le imprimia un temperamento y establecia un vinculo entre el hombre y la voluntad divina. El tonalli del dia en que un niño nacia podia ser positivo o negativo para su vida futura. Los simbolos básicos del calendario adivinatorio se formaban por la combinación de veinte figuras de animales y trece numerales, integrando un ciclo de 260 unidades. Este ciclo era un instrumento para conocer los influjos que serian dominantes en cada individuo. Esta fuerza vital que se encontraba alojada en el niño mantenia sus vinculos con el cosmos, sin embargo, todos los seres vivos -no sólo los hombres- estaban infiltrados por la fuerza vital del tonalli. (1980: 223-233).

Hoy en dia, para los nahuas el ekawil es de naturaleza fria y el tonal de naturaleza caliente. Puesto que el ekawil es externo al individuo, puede percibirse con cierta facilidad y denotar cuando el tonal se encuentra enfermo. O bien, suele ocurrir que el ekawil se disguste si un individuo se conduce de forma inapropiada y desprenderse entonces de su entorno inmediato, provocando con ello que el tonal se enferme. Cuando el ekawil se separa del cuerpo de una persona es percibido como un viento frio. Los trastornos ocurridos sobre el ecawil afectan inevitablemente al tonal.

El tonal tiene la capacidad de abandonar el cuerpo de un individuo, sin que éste pueda evitarlo o controlarlo. Lo más común es que ello suceda a causa de un susto, pero también puede ocurrir durante el sueño o por encontrarse en estado de ebriedad. Así mismo, este abandono puede ocurrir, como decía líneas atrás, como consecuencia de haber efectuado una conducta irreverente hacia los dueños de los manantiales de agua, del bosque, o de los cerros, quienes por ese motivo pueden atrapar el tonal de la persona, la cual resultará afectada en su integridad fisica. La recuperación del tonal requiere de una serie de rituales propiciatorios para obtener el regreso de esta entidad energética al cuerpo del individuo. La pérdida del tonal o tonalwetzi, causa serios trastornos físicos y puede culminar con la muerte si no es atendida a tiempo, mediante el ritual de tonaltzitzilia, o "gritarle al tonal".

En este ritual se ofrenda y se reza a Tlaltikpatli, a Tlalokan Nana y Tlalokan Tata, solicitando la restitución de esta entidad animica. Se aboga por el bienestar propio y el de los familiares cercanos, recurriendo a la gestión del tepahtiketl. Las plegarias se dirigen también a diferentes advocaciones de la Virgen Maria y santos católicos, en especial al santo patrono del pueblo al cual 
pertenece el enfermo.

Segre señala que en San Miguel Tzinacapan, en la Sierra Norte de Puebla, el tonal y el yolo son los dos elementos esenciales para la interpretación de la persona humana. El tonal está dentro del hombre como espiritu vital y en la naturaleza como un doble animal, mientras que el yolo es la irradiación vital, el respiro, el producto de la sangre, vinculo entre el tonal y el cuerpo. (Segre, 1987: 34). Con base en su investigación en Yancuictlalpan, poblado ubicado también en la sierra Norte de Puebla, vecino a San Miguel Tzincapan, Signorini y Lupo (op. cit.: 47-48) plantean que con el término yoloth, los nahuas designan a la principal de las entidades animicas y al corazón, donde reside y se transmite la energia al organismo; se encuentra asociado al equilibrio emotivo, a la conciencia y a la racionalidad.

A diferencia de la concepción de los nahuas de Zongolica, el término tonal en la Sierra Norte de Puebla se aplica al doble o alter ego animal del hombre. Según estos autores, la entidad animica designada como tonalli se presenta con el término ekawil/sombra. El ekawil constituye el eje de la relación de coesencia que liga al individuo con su alter ego animal, es el elemento esencial de contacto entre el tonal y el ecawil. Se encuentra distribuido por todo el cuerpo, aunque su sede principal es la cabeza, de donde se sale cuando el individuo sufre un susto (nemouhtli), en este sentido es equivalente al concepto de tonal de los nahuas de Zongolica.

Al igual que para éstos últimos, el ecawil se concibe como un viento suave, pero aqui tiene una calidad invisible, sólo sensible, que impide ver su salida, a diferencia de de lo que plantean los nahuas de Zongolica, quienes aseguran que en ocasión de un fuerte susto es posible ver -además de sentir- la salida del tonal del cuerpo del infortunado. El tonal es pues la energia cósmica que el individuo recibe al nacer y el yolotl cumple la función de mediador entre el tonal y el ihiyotl, entre la energia y las pasiones. Tanto Aguirre Beltrán (1980: 109-110) como López Austin (1980: 224) señalan que la idea de sombra proviene de los esclavos negros que llegaron de la costa de Guinea, del Congo y de Angola, donde el concepto de la pérdida de la sombra guardaba estrecha semejanza con el de pérdida del tonalli entre los indigenas, razón por la cual el concepto de sombra persiste hoy en dia en distintas partes de México y en algunos casos se sobrepuso al de tonal.

En concordancia con la doctrina cristiana, en Atlahuilco se considera que cuando una persona muere, el destino de su ánima (entidad animica que aparentemente se equipara a la concepción cristiana de "alma", y que sólo se manifiesta tras la muerte fisica de la persona), depende del comportamiento que se haya tenido en el paso por este mundo. Si su conducta fue adecuada, se dirigirá hacia el nwicatl, el cielo, pero si no ocurrió así, su destino será el Mictlan, lugar asociado con el infierno y ubicado en la parte más profunda de la 
tierra. Es necesario que los dolientes realicen una serie de rituales propiciatorios para que el ánima del difunto logre llegar hasta su destino final. Se le colocan dentro del ataúd: agua bendita contra los malos espíritus, siete tortillas con frijoles para que no sufra de hambre en el camino, siete semillas de cacao que serán las monedas que necesitará durante el trayecto, una rama de aguacate o de otro árbol frutal para que se defienda de los toros y borregos que se encontrará en el trayecto atacándolo por haber usado su carne y su lana para alimentarse y vestirse. También se le coloca su ropa de uso diario, su sombrero y su calzado.

Durante el funeral, se asume que el ánima de la persona reciên fallecida aún no se ha marchado, es decir, que se encuentra en un estado de transición entre la vida y la muerte. En estos momentos los dolientes hablan al difunto porque consideran que aún puede escucharlos; especialmente los padrinos, si aún viven, lo arengan a que acepte las ropas que se le entregan para que no sienta que se le permite marchar desnudo. En ocasiones se dificulta a los padrinos o familiares cercanos colocarles la ropa nueva con la que iniciarán su viaje al otro mundo, entonces se les ruega que por favor lo permitan (una mujer de Atlahuilco me relató que su abuela difunta no permitió que nadie más que ella le colocara sus aretes). También se le ofrece comida a este espiritu que se supone iniciará un largo viaje, atravesando campos, rios y montañas, acompañado de un perro que será benévolo y eficiente guardián sólo si en vida la persona dio buen trato a estos animales. Este animal se ocupa de llevar en su hocico el alma del difunto cuando atraviesa la última corriente de agua.

Entre los nahuas el perro es considerado un inseparable compañero de los hombres, desde el nacimiento hasta la muerte. Segün Garcia (op. cit.: 103) en los municipios de Astacinga y Tlaquilpa, el primer lazo de unión se establece cuando este animal consume la placenta del recién nacido. Si el bebé enferma se le soban al perro las patas delanteras, donde se supone que quedaron los restos de la placenta. Si el animal muere, se le degüella y descarna la cabeza, la cual se coloca encima de la cama del niño, mientras su cuerpo se sepulta cerca de la casa.

Estas concepciones tienen una evidente relación con el pensamiento de los antiguos mexicanos, para quienes la persona, al morir, iniciaba un largo viaje y en éste debia someterse a penosas pruebas: atravesar peligros y dificultades para llegar finalmente al borde de los nueve rios (chiconahuapan), los cuales debía cruzar con la ayuda de su perro. El Señor del Mictlan, Mictlantecuhtli, era el patrón del día perro en el calendario adivinatorio y domina el dia miquiztli, (muerte) cuyo signo era un cráneo descarnado (Soustelle. op. cit.: 142-143).

Durante las exequias, se colocan alimentos a un lado de cuerpo y se sirve comida y bebida a todos los condolientes en el mismo recinto donde descansa el 
difunto de cuerpo presente, para que se comparta con él una última comida. La intervención del padrino del fallecido (ya sea de bautizo o de cualquier otro sacramento) es indispensable en esta transición del individuo hacia la otra vida. El padrino es el responsable de adquirir el ataúd, las ceras, la cruz, el copal, los servicios de un rezandero y la ropa nueva con la cual su ahijado iniciará su recorrido.

El cambio de indumentaria es una de las fases más significativas de los funerales. El padrino se dirige al cuerpo recién tendido frente al altar sobre una sencilla cama de tablones, y le ofrece la ropa que le lleva, pidiéndole que le reserve un lugar en el cielo. Antes de vestirlo con la ropa nueva, sahúma cada una de las prendas y le implora que se deje colocar cada una de ellas, puesto que no desea que se vaya desnudo.

"Xi kita, xik tlasohkamati, inin tzotzol, tlen mitzi maka ixpantziko in totahtzi ti kilis onimitz tlakenti amo nikneki tikihto inimitz kahka xipetzi".

"Agradece estos pedazos de remiendo que te doy, delante de Dios, para que des cuentas de que te vesti. No quiero que digas que te solté desnudo". (Garcia, op. cit.: 115).

Una vez llevado a cabo el entierro, el ánima iniciará su recorrido. Al cabo de un mes habrá llegado a su destino; mientras tanto, se le ofrece comida diariamente frente a una cruz en el altar doméstico, la cual simboliza precisamente este espíritu desprendido del cuerpo ya sepultado en el cementerio. Al cabo de un mes -es decir, al final del viaje- se realiza la ceremonia de levantamiento de cruz presidida por los padrinos. Se consumen platillos rituales, se rezan rosarios y se cantan alabanzas durante toda la noche; al amanecer se lleva la cruz por fin al cementerio para colocarla frente a la sepultura, dando fin asi a los funerales. El ánima del difunto, sin embargo, puede retornar en distintos momentos, especialmente en las festividades de Todos Santos.

Se considera que al nacer todo individuo está ligado a la existencia de un animal, su nawal, pero la mayoria de las personas ignoran cuál le corresponde, puesto que es conocimiento reservado de los brujos o tetlahchiwimeh. Sousstelle señala que en Tequila el animal adecuado a cada individuo depende de un parecido fisico entre ambos; todos los animales de una especie son el nawal de una o más personas $(1958,118-9)$. Las personas que no poseen estos poderes especiales no conocen el animal que les corresponde como doble, pero asumen que tienen uno y que cuando a éste le ocurre algün daño, repercute en su propio organismo.

Además de identificar el nawal asignado a todo ser humano, los tetlahchiwimeh cuentan con la capacidad fisica para tomar la forma de su 
propio doble animal, con la finalidad de causar daños o perjuicios. Estas personas nacen predestinadas para adquirir estos atributos; en el momento de su nacimiento se detecta que tienen capacidad innatas: las parteras observan la forma en que se presenta la membrana que cubre el cuerpo del bebé (Garcia: ibid.). De ahi que generalmente el têrmino nawal sea equivalente al de tetlahchiwime; su capacidad de transfiguración en un ser de apariencia corporal animal, es considerada como una posible causa de severos trastornos en la salud que acontece eventualmente en la vida de los individuos; casi siempre lleva a la muerte como última consecuencia, y es fuente de continuas sospechas y conflictos interpersonales.

Según Segre (comunicación personal) el nawal o doble animal es el signo del tonal del individuo, señalado en el Tonalamalath, cálculo astral de los signos de la energia. Este cálculo permitia conocer la calidad y cantidad de la energia estrictamente individual desde el momento del nacimiento y se integró en el complejo chamánico como atributo o capacidad especifica de los brujos mesoamericanos. Estos se convirtieron en protectores de la comunidad, al igual que los santos patronos; mediante sus maleficios se cobran de los pueblos vecinos el tributo de vidas humanas que es preciso ofrecer a los dioses. Los habitantes de la sierra de Zongolica no dudan en reconocer la existencia de tetlahchiwimeh, pero se niegan a aceptar que persona alguna de su propio pueblo se dedique a tan indeseable oficio, el cual generalmente atribuyen a sus vecinos más próximos. De este modo, a través de la integración del catolicismo mediante la imposición de los santos patronos, y del complejo chamánico a través de los magos, los pueblos de la sierra han conseguido proteger, delimitar y definir su espacio social más inmediato. Ambos, brujos y santos patronos se encargan de proteger a los moradores del pueblo, barrio o localidad, de las incursiones y maleficios procedentes de los otros, al mismo tiempo que colaboran en el establecimiento de fronteras identitarias.

López Austin (1980: 420-432) afirma que en el pensamiento prehispánico algunos dioses lograban transfigurarse en animales, al igual que los muertos. Actualmente, en distintos puntos del área mesoamericana, el nawrual puede tomar distintas formas y es atributo exclusivo de los especialistas en el manejo de lo sobrenatural, mientras que el tonal, es el animal con el cual se relacionan los humanos desde sus primeros años de vida, pero no implica capacidad de transfiguración, es decir, el tonal parece estrechamente vinculado con el signo calendárico del Tonalamalatl.

Los nahuas de la sierra de Zongolica utilizan el término nawah, como decia lineas arriba, para referirse indistintamente tanto al doble animal con el que se relaciona todo ser humano, como a los tetalhchiwime, aludiendo a su capacidad de transfiguración; mientras que el tonal es la entidad energética que logra desprenderse del individuo y con ello desequilibrar el estado fisico y emocional de la persona. Aparentemente, no existe una relación explícita entre el 
tonal y el nawal o doble animal, pero persiste la idea del tonalli como condición necesaria de toda existencia, reserva de energia individual propia de todo ser humano. Es presente también la idea de calor que se expresa en la raiz tona y su relación con el sol y la energia cósmica. El tonalli constituia una fracción de la energia global que circulaba en el cosmos, realidad fisica y potencial que era canalizada hacia el beneficio colectivo mediante el sistema de predestinación azteca basado en el Tonalpohualli. Este sistema adivinatorio sintetizaba las predisposiciones particulares, a fin de proporcionar al grupo social los medios de su equilibrio y su reproducción (Duverger, 1980: 72-83).

\section{c) Las imágenes de los santos.}

Además de las deidades invisibles que habitan el universo de los nahuas, las imágenes de los santos católicos, deidades materialmente visibles, son objeto de culto y veneración y dan lugar, como hemos visto en los capitulos anteriores, a un ceremonial elaborado y complejo.

El complejo ceremonial de culto a las imágenes de los santos, sostiene el intercambio simbólico entre los seres humanos y los santos: éstos brindan protección a la colectividad y proveen de beneficios individuales a los responsables directos de cada una de las fiestas dedicadas a ellos. Los hombres, por su parte, sostienen un ciclo de fiestas en su honor que se sustenta en una intensa circulación de dones y rotación de puestos. El intercambio con las imágenes de los santos se realiza a través de ofrendas de flores, humo de copal, danzas, banquetes y libaciones.

Las imágenes de los santos que se localizan en cada templo o capilla se poseen de forma colectiva. Se considera que todo aquel que vive dentro de los limites de un espacio municipal se encuentra por ese sólo hecho, bajo la tutela del santo patrono respectivo y con la obligación de colaborar en el mantenimiento del ciclo anual de fiestas. En Atlahuilco, las imágenes que existen dentro de los limites del territorio municipal deben colocarse en el interior del templo principal -con lo cual se convierten en responsabilidad de todos los habitantes-, o bien en alguna de las capillas ubicadas dentro de dicho territorio, quedando a cargo sólo de los residentes en el paraje o rancheria correspondiente.

Por ejemplo, en el templo principal de Atlahuilco existen 45 imágenes, en Zacamilola, (la congregación con mayor número de habitantes en el municipio) se localizan nueve, en Atetecoxco, paraje cercano a la cabecera se encuentra sólo una, en Atlehuaya se localizan tres. La mayoria de estas imágenes son de bulto, hechas de yeso o madera; las menos son lienzos coloniales que han sido retocados por las manos de los mismos pobladores. Las imágenes se colocan sobre repisas o mesas, a lo largo de los muros del templo; las dedicadas al santo patrón se colocan en el altar mayor y aquellas que se consideran de más alta jerarquia se colocan a los lados de éste, en los altares laterales. 
Todas las imágenes deben recibir "su servicio" semanalmente, mismo que consiste en colocar flores frescas y veladoras nuevas, responsabilidad del mayordomo correspondiente. $\mathrm{Si}$ es dia de su santo debe ser además cambiada de ropa, puesto que saldrá del templo en más de una procesión. Cada una de estas imágenes tiene una réplica de menor tamaño que casi nunca está dentro del templo, puesto que va de uno a otro hogar, para recibir veneración a través de obsequios de flores, ofrecimiento de humo de copal, de plegarias, danzas, banquetes y libaciones.

Algunos santos católicos son invocados conjuntamente con las deidades dueñas de los distintos planos del universo. Por ejemplo, en los rituales agrarios que se realizan en Zacamilola antes de la siembra, se concibe que San José ayuda a San Antonio, al Santo Sol y a Tlalokan Tata y Tlalokan Nana en las labores de asignar buenas cosechas a los agricultores, es decir son corresponsables de la fertilidad agricola. Como plantea Ruz (1997: 392), el hecho de que elementos propios de las culturas agricolas hayan sido incorporados a la esencia de los santos, pese a no poseerlos en la tradición católica, muestra claramente el papel sustituto del santoral católico en las religiones prehispánicas. En el ritual con que se inicia la siembra en Atlahuilco se reza una oración en lengua náhuatl que se traduce asi, según un oficiante de Zacamilola:

"Tierrita de mi alma, tierra de mi corazón, Tlalokan Tata, Tlalokan Nana, San Antonio Auan y San Antonio Auana, San José y nuestro Santo Sol el que nos da la luz, aqui venimos para darte gracias y pedirte perdón. Te traemos unas velas, flores, copal y aqui traemos a los peoncitos, los que sembrarán el maicito de mi alma, frente a ti te pedimos que produzcas".

San Antonio, cuya fecha de celebración (el 13 de junio) corresponde al inicio de la temporada de lluvias, aparece asociado a los dueños del agua ${ }^{4}$ y a San José, cuya fiesta corresponde al inicio del ciclo agricola (el 19 de marzo). San Antonio Auan y San Antonio Auana son imaginados como una pareja cuyos vástagos son las plantas cultivadas por los hombres.

Para los nahuas, igual que para otros pueblos mesoamericanos, cada imagen es una entidad per se (Ruz, op. cit.: 403). Las imágenes femeninas, ya sean advocaciones de la Virgen María o Santas, como Magdalena o Santa Rosa, son consideradas "virgenes" o Tonantzin, el equivalente femenino de "santitos". El término genérico es ixpitla, que se traduce como "imagencitas". De igual manera, las advocaciones de Jesucristo tampoco se entienden como una categoria aparte, simbolización del dios cristiano, sino como representaciones autónomas. De tal modo, las festividades de Semana Santa se inician con la mayordomia de San Ramos, el Domingo de Ramos; continúan con la Ultima Cena donde intervienen los apóstoles para acompañar a Padre Jesús Nazareno;

\footnotetext{
4 Ahua o aua, significa dueño, poseedor de agua según Simeón, 1988: 44.
} 
el Viernes Santo se venera a Señor Calvario y a Santo Entierro y el Domingo de Pascua a Señor de la Resurrección.

Como señala Segre al referirse a las festividades de Semana Santa en San Miguel Tzinacapan, las representaciones de Cristo no son interpretadas como momentos sucesivos en la historia de su sacrificio, sino como "símbolos diversos y autónomos del drama religioso del hombre y del cosmos" (op. cit: 42). Paralelamente al ritual público de Semana Santa, cada una de las imágenes mencionadas cuenta con su mayordomo y el ceremonial relativo a toda mayordomia. La escenografia desplegada durante las festividades de Semana Santa, en la cual se intercala la participación de las imágenes con la representación teatral de personas de carne y hueso, resulta especialmente interesante en este mismo sentido.

Los nahuas asocian el prodigio de los santos de su panteón local -no sólo de los tutelares- a la solución de las penurias y sufrimientos. Por ello es tan relevante el sostenimiento de un ciclo ritual repetitivo, en el que se festeje a cada uno de los iconos que se localizan en cualquier templo o capilla del municipio. Cada entidad sagrada requiere de una continua confirmación de su posición en el seno de la comunidad. Como divinidad protectora, su papel en la protección simbólica del pueblo debe asegurarse un ciclo tras otro. Incluso aquellos individuos que no participan materialmente en las disposiciones ceremoniales para la continuidad de este ciclo vital, se asumen como protegidos, se benefician del cumplimiento de la sucesión de momentos sagrados que llevan a cabo el grupo de mayordomos y demás autoridades religiosas locales. Esta comunidad de santos es concebida pues como un panteón de deidades antropomórficas y no como intermediarios entre los hombres y Dios (Báez-Jorge, 1998: 114).

Nutini (1988) apunta que los indios mexicanos contemporáneos no han internalizado la distinción teológica entre dios y los santos, y generalmente asignan un rango mayor al santo patrono del pueblo que a Dios, de modo que no se adhieren al dogma católico del monoteísmo. Según este autor, los santos se presentaron a los indios como entidades ideológicas que integraron en su propio sistema religioso identificándolos con los dioses de su panteón. Ha sido señalado por distintos estudiosos el papel de los santos patronos en los procesos de conformación de las identidades locales en las regiones indigenas. Nutini y Bell afirman que es ésta una caracteristica común en los pueblos de Mesoamérica (1989: 295-296). Evidentemente, la estrategia de evangelización diseñada por los frailes durante la colonia, basada en la instauración de santos patronos resultó de amplios alcances en el ámbito de la organización social y los procesos de integración locales y regionales.

Garcia Martinez (1987) y Florescano (1997) entre otros, han documentado el proceso que acompañó la constitución de los pueblos de indios durante la colonia al transformarse el altépetl indigena. El espiritu corporativo de estos 
pueblos se simbolizó en la iglesia local, en su santo patrono, en su mercado y en sintesis en las fiestas anuales del santo patrono. A partir de estos simbolos se reconstruyeron las identidades locales. Maurer apunta que para los tzeltales la fiesta del santo patrón es el sacramento de la vida en comunidad (1996: 45).

Gruzinski (1995: 189) desarrolla una interpretación acerca de los procesos mediante los cuales los pueblos de indios se convirtieron en consumidores de imágenes de santos. En la concepción indigena, el ixiptla fue el receptáculo mismo de poder, no una similitud de forma. La imagen se convirtió en un interlocutor, en una potencia con la cual es posible negociar, regatear, sobre la cual se ejercen presiones y pasiones. "El santo es una entidad que se basta a si misma y no se resume en la dialéctica del significante y del significado". Como señala Rubial (1997: 362) la existencia de santos locales creó nuevas formas de socialización en la Nueva España, aquellos se convirtieron en los intermediarios celestes propios para asegurar la fertilidad y la salud.

Aguirre Beltrán (1986: 95)) planteó que bajo la etimologia simple de los nombres de los pueblos de la Sierra de Zongolica, se puede develar el sentido profundo de los topónimos. Según este autor, existió una estrecha asociación entre el significado abscondito de los topónimos locales, y la adjudicación de cada uno de los santos patronos instaurados en los pueblos de la sierra de Zongolica. Atribuye este proceso a los frailes franciscanos que iniciaron las labores de evangelización en la zona hacia los primeros años de la colonia. Los rasgos que configuran la imagen del santo se integran en el topónimo, vinculando la nueva doctrina con el nombre del lugar, el cual tiene su origen en la religión mesoamericana, haciendo énfasis en los atributos de dolor, resignación y martirio. Asi por ejemplo, señala que para Texhuacan, cuyo topónimo significa: lugar del sol mancebo, "el sol joven de las mañanas llamado Telpochtli" (p. 107), los franciscanos adjudicaron a San Juan como santo patrono. Las propiedades del dios nativo se dan en Juan el Bautista y en Juan el Evangelista, de modo que al sincretizarse los tres héroes conjugan sus cualidades, quedando asi plenamente identificado el santo patrón cristiano con el pensamiento de los indigenas.

Hoy en día los nahuas serranos consideran a su santo patrono local como una divinidad con atributos especiales de poder y de prodigios. Se asume que cada santo patrono es el protector de los habitantes que pueblan un territorio delimitado a partir de los linderos municipales; de este modo se distribuye la protección simbólica en la región nahua, dando lugar a la conformación de un orden divino en el plano regional. En ocasiones, los santos tutelares -según versiones locales- han adquirido enemistades con los protegidos de otros santos debido a irreverencias o incredulidad acerca de sus atributos. Tal y como lo expresara Lôpez Austin refiriéndose a los dioses patronos prehispánicos, los pueblos son más próximos entre si cuando existen relaciones de parentesco o amistad entre sus respectivos dioses patronos (1994: 38). 
Al igual que para los tzotziles, para quienes Dios dividió las tierras del mundo entre los distintos pueblos y envió a sus hermanos, los santos, para que fundaran los municipios (López Austin, op. cit.: 109), en cada pueblo de la sierra de Zongolica se narra la llegada del santo patrono respectivo, como una forma de constatar que éste estableció determinados nexos personales con el espacio comunitario: su aparición en un punto especifico del territorio municipal (una cueva, una cañada, una elevación). De este modo, la biografia del santo se adecúa a las condiciones locales y justifica las caracteristicas fisicas del entorno.

Esta instauración de santos patronos en la sierra de Zongolica, puede ser interpretada, desde la perspectiva de López Austin, como una apropiación de las iconografias católicas, a través de un proceso formador que construyó las hazañas de estos personajes bajo una perspectiva propia. Es decir, implica un argumento dramático. Grimes refiere que el dramatismo de los iconos reside en las historias que se cuentan respecto a ellos o en los rituales que se les celebran (1981: 177).

Por ejemplo, San Martin Caballero, patrono de Atlahuilco, tiene una biografia que se considera anterior a su llegada al pueblo; en ella se narra su vida como un soldado húngaro que en una ocasión cubrió con su manto a un mendigo, llegando a ser más adelante el obispo de Tours, Francia. En Atlahuilco se venera a las dos imágenes que representan estas dos fases de su vida: una es la de San Martín Caballero, el soldado en su caballo, ofreciendo su capa a un personaje doliente y semidesnudo; la otra, la de San Martin Obispo, ataviado con la indumentaria eclesial, misma que ocupa el altar mayor. Cabe señalar, que aunque se asume que las dos imágenes son igualmente importantes dentro del ciclo ceremonial; el pueblo asume una mayor identificación con el soldado a caballo, cuya figura es más alegórica y es anecdótica por sí misma. La existencia de dos versiones distintas del santo patrono, implica el desarrollo de dos fiestas de mayordomia -una para cada imagen-, como si se tratara de santos diferentes, pero dándoles a ambas el estatus de santo patrono tutelar.

A partir de su llegada al pueblo, San Martín inició una serie de hazañas imaginarias que afirmarian su pertenencia al lugar, su familiaridad con sus habitantes. Se le atribuye una prosopopeya que lo vincula con criterios sociales de pertenencia, distribución y jerarquia. (López Austin, 1990: 258). Tal parece que fue necesaria la personificación momentánea de la imagen para volver de nuevo a la divinidad pera ya investida de una personalidad local. Aquí se presenta la referencia al tema incoactivo, al paso entre el tiempo-espacio divino y el tiempo-espacio de los hombres.

Los relatos alusivos a la aparición de San Martin y San Isidro aluden a la geografia local, a la distribución de elementos naturales y a la delimitación de las fronteras comunitarias. Se dice que San Isidro y San Martin -ambos blancos y 
barbados- eran hermanos, y llegaron a la sierra de Zongolica procedentes de España. El primero traia una yunta de bueyes, mientras que el segundo llegó montado a caballo. En su incursión por la región arribaron a Atlahuilco, sedientos, después de su largo peregrinaje. San Isidro solicitó agua para sus bueyes y se la negaron, pero él levantó una piedra y de ahi brotó agua de inmediato, la cual ofreció a sus animales. Decidió partir a Xoxocotla, municipio vecino, en donde le dieron toda el agua que él necesitaba y en castigo dejó al pueblo de Atlahuilco sin el vital liquido. En Xoxocotla, donde se quedó San Isidro como santo patrono, abundan ahora los manantiales.

A San Martín le gustó Atlahuilco para quedarse. Pidió posada en una casa, pero a la mañana siguiente se fue muy temprano y sin despedirse. Lo buscaron por el rumbo y lo encontraron en una pequeña choza, con techo de zacate que se ubicaba en el punto donde después se construyó el templo. Pero cuando lo localizaron ya se habia convertido en imagen, y entonces llegó un grupo de hombres a llevarselo, porque habia desaparecido de su lugar de origen y lo habian buscado durante varios días. Sin embargo, al llegar a determinado punto, la imagen se volvió tan pesada que tuvieron que dejarla ahi. Poco después apareció de nuevo en el mismo sitio donde se edificó su templo.

Otra versión acerca del establecimiento de San Martín como santo patrono de Atlahuilco, también refiere que éste no llegó solo a la región, sino acompañado de tres hermanos más: Santiago (quien se estableció como patrono de Tehuipango), y otros dos homónimos, es decir también llamados Martín, quienes decidieron marchar hacia otros puntos. Como ocurre respecto a San Isidro, para los pobladores de Atlahuilco, es evidente el parentesco de San Martín y Santiago: ambos son barbados y ambos montan a caballo. Estos cuatro hermanos incursionaban por la región buscando un lugar para establecerse y cada uno quedó lejos del otro. San Martín llegó primero a Atlehuaya, el poblado ubicado en el punto más alto del municipio de Atlahuilco, pero no le agradó porque se encuentra entre cerros y cañadas, y decidió asentarse en Atlahuilco, en "el plan". San Martin sale cada noche a buscar a sus hermanos porque desea que vengan a vivir con él. Los ancianos cuentan que tiempo atrás se escuchaba por las noches a un hombre a caballo deambular por el pueblo, era San Martín, a quien se le reconocia por el sombrero y su manga de hule. Desde entonces, se amarra una de las patas delanteras del caballo a una estaca agregada a las representaciones de San Martín Caballero. Se trata de un santo vagabundo.

Los pobladores de Tehuipango, sin embargo, relatan que Señor Santiago es originario de ahi mismo. A pocos kilómetros de la cabecera municipal se localizan los vestigios arqueológicos -en parte ocupados por plantas de maíz y en avanzado deterioro- de una pirámide, ubicada en un punto elevado que permite el dominio visual de una vasta área. Se dice que fue alli donde nació Señor Santiago y que ahi se ubicaba en tiempos antiguos la ciudad de Orizaba, hoy importante polo industrial de la franja central veracruzana, ubicada en el valle 
donde inicia la bocasierra. Aguirre Beltrán consignó también esta versión acerca del santo tutelar de Tehuipango (1986, 125-127).

A través de la reelaboración de las biografias individuales, los nahuas enfatizan los vinculos de sus santos patronos con su entorno; relacionándolos casi siempre con la fundación de cada pueblo. Se interpreta su llegada como de otro espacio-tiempo, muy ajeno a la realidad local, como si su existencia anterior a su llegada fuera intemporal, pero su arribo al espacio étnico marcara un renacimiento de su individualidad que los identifica estrecha y exclusivamente con sus protegidos: una etapa distinta en su biografia que les imprime una presencia casi humana. De este modo, se convierte en icono milagroso al alcance de sus devotos, con nexos familiares con los santos patronos de otros pueblos y hasta con manifestaciones corporales que renuevan cada dia sus cualidades humanas como el sangrar, llorar o sudar.

Como señala Ruz (op. cit.: 392) refiriéndose al imaginario hagiográfico de los mayas, sea cual fuere la naturaleza o jerarquia de los santos, éstos son tenidos casi siempre como entes individuales encarnados en sus propias imágenes. Por ejemplo en Atlahuilco, las imágenes más importantes del santoral cuentan con una réplica, de manera que su celebración sea doble y permita a dos mayordomos hacerse cargo de su fiesta, en ocasiones simultáneamente; tal es el caso, por ejemplo, de San José Primero y San José Segundo, Santisimo Primero y Santísimo Segundo, San Martin Caballero y San Martin Caballero Chico (cuya fiesta se concibe como una réplica de la fiesta patronal, pero de menores proporciones y en una fecha distinta).

En Atlahuilco, una historia local ilustra claramente la forma en que la pugna por el establecimiento de limites con el municipio de Tlaquilpa, permite recurrir a los santos patronos de cada pueblo como protagonistas principales, hasta convertirlos en simbolo epónimo, punto de referencia con relación a categorias de espacio y tiempo.

En una ocasión los habitantes de Tlaquilpa (municipio vecino de Atlahuilco que tiene como santa tutelar a Maria Magdalena) y los de Atlahuilco discutian encarnizadamente por cuestiones relativas a los linderos municipales. Con el fin de llegar a un acuerdo justo ante un problema aparentemente irresoluble, puesto que ambos bandos consideraban tener la razón, decidieron realizar una competencia: cada bando se ubicaria en un punto situado a una distancia determinada del lugar en conflicto pero en sentido opuesto, de ahí se dirigirian hacia el centro y el grupo que llegara primero obtendria una resolución a su favor.

Los vecinos de Atlahuilco resultaron ganadores, provocando con ello el enojo de sus vecinos, quienes se quejaron argumentando que no era posible que hubieran ganado los de Atlahuilco, cuyo santo patrono no era más que un soldado. Estos 
se consideraron ofendidos por el hecho de que se hubiera despreciado a su imagen. Acudieron de inmediato a llevarle flores y velas y a tratar de disculpar la osadia cometida por sus adversarios, pero a pesar de ello mucha gente de Tlaquilpa enfermó a causa de una epidemia que ocasionó sufrimiento y muertes. $\mathrm{El}$ asunto no se arregló hasta que los responsables acudieron al templo llevando flores y veladoras y solicitando el perdón de tan poderosa imagen. Este historia me fue relatada por un habitante de la cabecera municipal de Atlahuilco, destacado conocedor de las cuestiones ceremoniales, quien orgulloso de los prodigios y personalidad propia de su santo patrono concluía diciendo: "este santito de por si es malito si lo hacen enojar". Encontramos asi esa dualidad benefactor/vengativo que Ruz también encuentra entre los santos mayas (op. cit.: 398).

Las actitudes corporales humanas son parte de los prodigios de las imágenes de los santos (Rubial, op. cit.: 361). Según los lugareños, "San Martín Caballero ha sido siempre muy andariego". En otros tiempos acostumbraba escaparse del templo por las noches, mientras el pueblo dormia. Cuando los semaneros (pareja de sacristanes encargados de cuidar el templo durante una semana) se levantaban por la mañana aún de madrugada, y se acercaban al altar para saludar al santo patrono, se encontraban con que éste no estaba. Más tarde, volvian de nuevo y lo encontraban ya en su lugar, con las mejillas enrojecidas, como después de una larga cabalgata. De algún modo se supo que por las noches cabalgaba para visitar a su hermano en San Martin Texmelucan, en el estado de Puebla. Desde entonces se decidió poner una estaca en la base de su escultura, a la que se ata una de las patas de su caballo, de este modo se evita que se escape de su casa (el templo) por las noches. Las actitudes corporales se extienden a su caballo, al cual se entregan mazorcas, pastura y maiz desgranado durante los dias de la fiesta patronal.

Como mencioné en un capitulo anterior, la fiesta de Corpus Christi es una de las más importantes del calendario. Señala el inicio de un periodo en que decrece la actividad ritual, cuando escasea el maiz, aún faltan meses para la cosecha y los hombres emigran en busca de sustento. Se realiza en el inicio de la época de lluvias y en su celebración hasta hace pocos años, se soltaba una paloma a mitad del templo; la dirección que tomara su vuelo era un presagio de la forma en que resultaria el temporal: si buscaba la salida y volaba libre, lloveria lo suficiente pero sin causar estragos en los cultivos, pero si se quedaba atrapada dentro del templo habria inundaciones por la creciente del arroyo que atraviesa el pueblo.

Dado que es esta una fiesta marcadora de tiempo, también en este caso los pobladores de Atlahuilco han creado dos mayordomías para venerar a dos réplicas de la imagen: Santisimo Primero (la de más jerarquía) y Santisimo Segundo. Ambas se celebran casi simultáneamente, siempre y cuando el día exacto de la fiesta marcado en el calendario se asigne a Santisimo Primero. En 
el verano de 1995 presencié esta festividad doble y en aquella ocasión, el mayordomo de Santísimo Segundo realizó la culminación de su fiesta, (llamada "la entrega" de la imagen) un día antes de "la entrega" de Santisimo Primero.

En la celebración de las "visperas" de Santísimo Primero (la noche anterior a la entrega" del cargo), se celebró una misa y posteriormente el pueblo reunido en el atrio esperaba la quema del castillo de pólvora, evento poco usual debido al alto costo que representa. Mientras tanto, una banda de música de viento alegraba la noche y un grupo de "moros", danzantes de la congregación de Atlehuaya, realizaban evoluciones y saltos entrechocando al unísono "la palma" de sus machetes. El mayordomo y su comitiva escanciaban aguardiente y cerveza en un ambiente de reposada alegria. De pronto, el silencio se hizo presente cuando alguien anunció que había llegado el momento de quemar el castillo. Brillaron las luces a cierta distancia del atrio (a unos cien metros) de modo que los ahi presentes lográramos observarlas en todo su esplendor.

Las campanas iniciaron un repique que de súbito creó una atmósfera sacra; el mayordomo se introdujo en el templo para tomar en sus manos la imagen festejada (una paloma con destellos dorados) y llevarla hasta la puerta para que presenciara el espectáculo dedicado a ella. La gente guardó silencio y la banda cesó sus acordes para dejar oír el tañido de las campanas. Los sacristanes o semaneros en turno, se apresuraron a sacar también "la cruz alta" y los candeleros, reliquias doradas que encabezan las procesiones. Instalaron todos estos objetos sagrados en la puerta del templo, en dirección hacia el castillo de pólvora que ardia en chispazos y cohetes sobre un fondo oscuro y perfumado de flores.

Las luces de bengala iluminaron la fresca noche de verano. El mayordomo y su comitiva escoltaban a la paloma de metal mirando todos hacia el punto donde las luces estallaban, mientras el humo del incienso impregnaba el conjunto y continuaba el repique de las campanas. La gente permaneció inmóvil e impasible durante los quince minutos que duró el espectáculo, fundida la mirada con la de los iconos. Una mujer que me acompañaba me comentó entonces con emoción: "sacan a las imagencitas para que vean el castillo porque es su fiesta". Terminado este acto, la reunión en el atrio se disolvió y sólo la comitiva del mayordomo antecedida por la banda de música, interrumpió la repentina calma nocturna dirigiéndose hacia su casa para continuar la fiesta durante toda la noche. Los danzantes, mientras tanto, se despojaban de su traje para descansar por fin de tantas evoluciones y choques de machetes.

\section{d) Una recapitulación: ritual e intercambio simbólico.}

Como he señalado en las páginas precedentes, para los nahuas las imágenes de los santos son las deidades visibles, pero existen también dioses ocultos, dueños de ciertos ámbitos naturales, fuerzas que se veneran y se honran a través de 
determinados rituales. Este panteón local se reparte el universo en dos secciones: la naturaleza y el mundo de los hombres. Los dioses ocultos son los dueños de los montes, cerros, cuevas, manantiales de agua, animales silvestres y de la superficie terrestre y pueden incidir en la integridad individual de los seres humanos en casos de transgresión, sustos o incidentes circunstanciales. Las imágenes de los santos son las protectoras de los hombres en su bienestar colectivo, por ello el mantenimiento del ciclo anual dirigido a su culto se asume de forma rotativa entre los habitantes, aunque se acceda también a una dimensión personal en términos de los beneficios adquiridos.

El diálogo con ambos tipos de divinidades se realiza siempre mediante una relación de intercambio. Danzas, procesiones, flores, banquetes y libaciones se ofrendan a las imágenes de los santos a cambio de la protección simbólica que ejercen sobre su pueblo. Las oraciones, el humo de copal, las flores, el aguardiente y los alimentos que se ofrecen a Tlaltikpaktli en la intimidad de los hogares, en los terrenos para sembrar o en los sitios donde ocurrió algún incidente, aseguran la protección $\mathrm{y}$ el alivio del individuo afligido por la enfermedad, la desgracia o la incertidumbre ante su destino. A diferencia de lo que ocurre entre los nahuas de la Huasteca Veracruzana (Sandstrom, 1991) en la sierra de Zongolica el ritual no incluye el ofrecimiento de sangre de animales, ni se efectúa el culto de los papeles ceremoniales que en aquella región representan a distintas divinidades.

El intercambio con las imágenes de los santos se realiza a través de la fiesta, de la celebración colectiva, que persigue el establecimiento de un orden en la sociedad y en el devenir de las regularidades del tiempo y espacio sociales; sus beneficiarios son los hombres en colectividad. Los rituales dirigidos a los elementos naturales conceden a los individuos el restablecimiento de la salud en los casos en que han sufrido un susto y como consecuencia de ello, la pérdida del tonal, o bien abogan por el éxito de las cosechas o de las incursiones por el monte para aserrar árboles o elaborar carbón. En este tipo de rituales se recurre a la gestión de un intermediario, el tepahte, quien en caso de enfermedad llama al tonal extraviado y ofrenda a Tlaltikpaktli ramilletes de flores, velas, copal, tabaco, pétalos de flores, aguardiente, café y alimentos. Una ofrenda similar será colocada en el terreno previo a la siembra, en una casa antes de ser habitada y después de la serie de baños terapéuticos que se toman en el temazcal o baño de vapor luego del parto. En la fiesta del día de la Santa Cruz, el tres de mayo, se coloca una ofrenda análoga en los manantiales y nacimientos de agua que abastecen a los pobladores, en un ritual de agradecimiento y de petición de lluvias. En cambio, la colocación de ofrendas semejantes en la entrada de las cuevas y oquedades se ofrecerá solamente como forma de prevenir el enojo de los señores del Tlalokan cuando es necesario incursionar en dichas concavidades debido a alguna circunstancia particular, o como una forma de solicitar perdôn después de algún accidente que se supone fue causado por haber entrado sin efectuar el procedimiento ritual prescrito. 
De modo que el xochitlali, ofrenda de flores para la tierra, es la práctica ritual que sintetiza la concepción de los nahuas en términos de relaciones de hospitalidad con la naturaleza, especificamente con la Tierra (Alvarez, op. cit.: 9). Como he planteado páginas atrás, en esta concepción de la Tierra persisten las atribuciones primordiales de la Madre Telúrica, que remite al antiguo sustrato cultural mesoamericano (Báez-Jorge, 1988: 227).

Este ritual se orienta hacia los aspectos más relevantes de la vida: como ritual de purificación, como práctica curativa, como ritual propiciatorio de las lluvias y la fertilidad. Aunque las invocaciones y algunos elementos del ceremonial varian en cada caso, siempre se dirigen hacia Tlaltikpaktli, Tlalokan Nana y Tlalokan Tata, hacia los cerros ubicados hacia los cuatro puntos cardinales y hacia algunos santos católicos, especialmente el santo patrono del lugar. En cada caso, es un especialista ritual el intermediario entre los hombres y la divinidad: la partera, después de la cuarentena de la serie de baños de purificación, el tepahte, cuando se realiza el ritual en su version de Tonaltzaltzili para reintegrar el tonal en el cuerpo de su paciente, o el xochitlake, quien dirige la invocación en su orientación de ritual agrario o propiciatorio de las lluvias.

Tanto las prácticas curativas, como los rituales propiciatorios y agrarios y las fases de las fiestas de mayordomia desarrolladas en los hogares, poseen la característica común de realizarse en el seno de los espacios domésticos o los campos de cultivo de los particulares, mientras que la fase pública de las fiestas religiosas del calendario anual dedicadas a las imágenes de los santos, especialmente las de las fiestas de renovación del centro ceremonial se efectúan en el templo católico y el atrio, espacios eminentemente públicos. Es decir las primeras pueden ser clasificadas como rituales domésticos, mientras que las segundas como rituales comunitarios.

Esta división, en términos esquemáticos puede ser también una medida de la identidad local, puesto que en un sentido muy general representan la división entre la población indigena y la mestiza. Como mencioné en el Capitulo III, este contraste depende del espacio en el cual se realizan los rituales. En tanto que la población mestiza de Atlahuilco se presenta durante la celebración de la misa y las procesiones alrededor del templo después de cada fiesta, durante el ceremonial de la mayordomia que se lleva a efecto en los altares domésticos participa casi exclusivamente la población nahua. Del mismo modo, puede afirmarse que el ritual del xochitlali, en cualquiera de sus orientaciones, es un ritual más bien indigena hacia el cual, indudablemente, recurren también ocasionalmente algunos habitantes mestizos, asi como hacia el conocimiento de los curanderos y médicos tradicionales. 


\section{CAPITULO VI}

\section{IDEOLOGIA ETNICA, MEDIACIONES CULTURALES Y DIVERSIDAD RELIGIOSA.}

En el curso de los capitulos anteriores he caracterizado el modelo de organización ceremonial de los nahuas de Atlahuilco basado en el culto a los santos bajo el sistema de cargos, tratando de incorporar una perspectiva que considere los distintos niveles de la organización intracomunal del sistema. Se argumenta por qué se ha tomado el sistema de cargos como el mecanismo más significativo de descripción de las relaciones a nivel comunal, en el cual predominan procesos interpersonales de organización. No obstante, como señala Signorelli, la comprensión de dinámicas culturales requiere de la consideración de las relaciones que se activan cuando las estructuras de pequeña escala interactúan con estructuras de gran tamaño, es decir los nexos concretos entre el orden local y el de las escalas extralocales, con las cuales se relacionan e interfieren reciprocamente (1994: 53).

En las siguientes páginas me ocupo de plantear algunos de los nexos que se establecen entre estos dos órdenes de relación, a través de un acercamiento a la perspectiva de los sujetos activos en la comprensión y construcción de su entorno social. Haré referencia a las corrientes y facciones que en Atlahuilco posibilitan nuevos reajustes entre las esferas politica y religiosa y en los procesos culturales locales. Tocaré, entre otros aspectos, el asunto relativo a las denominaciones religiosas que han ganado ciertos espacios en el entorno regional, puesto que es evidente que el cambio religioso ha incidido, aunque en ocasiones de forma indirecta, en la dinámica de las relaciones entre agrupaciones residenciales, en la participación en las fiestas de renovación del centro ceremonial y en la configuración, en fin, de las relaciones sociales.

En el marco de los procesos regionales más amplios, Altahuilco presenta cambios fundamentales en lo que en términos de Nutini y Bell (1989: 382) se consideraria un cambio de ideologia: "la transformación de las bases ideológicas de la vida de la comunidad, desde un fundamento primordialmente socio-religioso a otro primordialmente económico". En los últimos años, los pobladores de Atlahuilco incorporan pausada pero claramente nuevas forma de concebir su condición social acorde con el proceso de "globalización cultural asimétrica", en el cual lo étnico, lo local, vuelve a apropiarse de poderes delegados a las organizaciones politicas tradicionales y se abre una contradicción entre los valores locales y aquellos que son introducidos por la globalización cultural (Segre, 1994: 188-189). Estos cambios se expresan fundamentalmente en actitudes de alto contenido autoconsciente en relación a la politica, al consumo, a la organización familiar, a la participación comunitaria y en el marco de este conjunto, al ejercicio de la religiosidad. 
En el ámbito de la organización política local las acciones se encaminan hacia la necesidad de resistir y responder a la situación de asimetria y marginalidad. Las facciones locales, fundadas en diferencias de filiación politica 0 religiosa 0 simplemente de solidaridad grupal de las microlocalidades, orientan sus esfuerzos hacia el autoreconocimiento y fortalecimiento de distintas vias de expresión. Es decir, se manifiesta con vigor un reforzamiento de prácticas de cohesión grupal a nivel de microlocalidades y facciones, asociadas con la búsqueda de control sobre sus propios recursos y de solución a intereses comunalistas. Se expresa al mismo tiempo, el deseo de mantener el establecimiento de fronteras claras frente a los otros y la supuesta unidad del pueblo en su conjunto. En el escenario politico se presentan, en consecuencia, transformaciones en la organización del poder a partir del surgimiento de nuevos actores.

La identidad, vivida a través de actos cotidianos "resulta de la interiorización selectiva, distintiva, y jerarquizada de elementos y rasgos culturales por parte de los actores sociales" (Giménez, 1998: 10). Las identidades colectivas se definen a partir de las representaciones socialmente construidas y compartidas, generando entre sus miembros orientaciones comunes a la acción. Es decir, no se trata de nociones escencialistas, sino de definiciones relacionadas con la confrontación y el conflicto: "...el espacio social puede ser considerado como un escenario donde entran $y$ salen, se hacen $y$ deshacen un gran número de identidades colectivas" (op. cit.: 14). De acuerdo con este autor, las identidades son suceptibles tanto de una transformación adaptativa como de alteración cualitativa, además, se encuentran generalmente interferidas por conflictos que llevan a la continua confrontación en sus dimensiones intraétnicas e interétnicas. De ahi que sea factibe hablar de un proceso evolutivo de las identidades, el cual remite a contextos histórica y socialmente especificos.

Como he tratado de argumentar en el curso de este trabajo, la religión constituye aún una dimensión fundamental de la identidad de los habitantes nahuas de la sierra de Zongolica, especialmente en torno a la figura de los santos patronos. Sin embargo, en determinadas localidades, el cambio religioso en mayor o menor grado, se constituye como una via para facilitar el recurso a mediaciones exteriores, y configurar nuevos patrones de cohesión. Según Bastian, a través de la pluralidad religiosa se teje una modernidad indigena que construye la articulación de la identidad étnica con la sociedad global, a partir de nuevas bases religiosas. Desde su perspectiva, basándose en el caso de Chiapas, donde se ha llevado a cabo la conversión de amplios sectores de comunidades tzotziles, tzeltales, choles, mames y tojolabales, el proceso de pluralización religiosa es un medio para impedir el sistema de explotación ligado a la fiesta tradicional y un semillero para el surgimiento de nuevos liderazgos plurales e independientes. 
(1997: 102-127). Hernández Castillo, apunta que entre los mames, los nuevos movimientos religiosos se han tornado en componentes de la etnicidad, sirviendo para señalar las diferencias, reforzar la cohesión y resistirse al cambio (1994: 97).

A partir de las últimas dos décadas se gesta un proceso de cambio religioso en la sierra de Zongolica, si bien no parece aún de dimensiones tan significativas como en el caso de Chiapas. Aguirre Beltrán (1986) lo hizo notar hacia mediados de la década de los ochenta, preguntándose acerca de las causas que estaba dando lugar a la conversión de indigenas nahuas hacia nuevos cultos. Señalaba que quizás los nuevos movimientos religiosos son un camino para ejercer el control político sobre las propias comunidades, y que el sistema religioso tradicional basado en el culto a los santos, estaria llegando probablemente a su fin.

El censo oficial de 1970, registró que la población no católica en la Sierra representaba menos del uno por ciento, en 1990 habia ascendido a un seis por ciento. Algunos municipios destacan en cuanto a número de conversos que aparecen registrados en los datos censales: Astacinga, Soledad Atzompa. Magdalena y Tequila. En Atlahuilco, según esta fuente, un 4.36 por ciento de sus habitantes se ha adherido a una religión distinta a la católica. No obstante que no se cuenta con un censo o diagnóstico que enumere las agrupaciones religiosas con sede en los pueblos de la Sierra, según mi propia observación, destaca la presencia de La Luz del Mundo, catalogada como un movimiento pentecostal de tendencia fundamentalista (Fortuny, 1989: 17; Vázquez, 1991: 146). Se encuentran también iglesias evangélicas independientes como Asambleas de Dios, Amistad Cristiana, Iglesia Cristiana, Pentocostés, iglesia evangélica fundamentalistas según la clasificación de Vázquez (ibid.), asi como Católicos de la Renovación Carismática.

En las páginas que siguen, me propongo reflexionar acerca del pluralismo religioso y su incidencia en lo que podriamos llamar la reconstrucción de las identidades locales. Trato de argumentar que en Atlahuilco hoy en dia, las prácticas ligadas al ejercicio de la religiosidad constituyen un epifenómeno de la diferenciación social $\mathrm{y}$ de las tensiones latentes, dando lugar a una reconfiguración de las lealtades, solidaridades e identidades locales.

\section{a) El sistema de cargos y la diversidad religiosa.}

A partir de la segunda mitad de este siglo, el modelo de organización ceremonial de Atlahuilco ha atravesado por las siguientes fases, de acuerdo a los testimonios de cargueros y funcionarios del templo:

1.- Un sistema de cargos que conjugaba puestos correspondientes a la esfera 
religiosa con cargos del gobierno civil, Aunque no se trataba de un sistema estrictamente alternante, los hombres que ocupaban cargos civiles comenzaban en la escala más baja siendo muy jóvenes (como topiles) y posteriormente se responsabilizan de celebrar una mayordomia de poca relevancia dentro del calendario anual, con el fin de ir conociendo los detalles del ceremonial y asumir años más tarde, compromisos religiosos de mayor monto. Su carrera en la gestión ceremonial suponia la adquisición de prestigio y posición social que los posibilitaba para ocupar puestos ascendentes en el gobierno civil.

Las autoridades civiles tenian la atribución de exigir el cumplimiento de cargos religiosos a los habitantes del municipio, atribución que se ejercia a través de sanciones -como el encarcelamiento- a quien se negara a hacerse responsable del asumir la responsabilidad de una fiesta de mayordomía o un puesto del gobierno de la iglesia, toda vez que se considerara que el individuo en cuestión contaba con la capacidad económica y requisitos sociales para ejercerlo. Al final de su vida, un hombre -y por extensión su grupo doméstico- habia pasado por diversos puestos entre una y otra esfera. Su reputación estaba en función de su actuación en ambas. Algunos puestos, como el de tekitlahto, combinaban funciones tanto civiles como religiosas. La ceremonia de cambio de varas que se realizaba el último día del año, celebraba la legitimación de los cargos tanto civiles como religiosos ${ }^{1}$. Hoy en dia, los puestos de topil y tekitlahto se mantienen aún, el primero de ellos corresponde al servicio en el ayuntamiento y es considerado obligatorio, mientras que el segundo se transformó en un puesto voluntario de carácter religioso, como señalé en un capitulo anterior. Los puestos de semanero o sacristán menor mantienen su connotación de servicio obligatorio; corresponden estrictamente a la esfera religiosa.

2.- En el curso de los años setenta, se consolidó la separación explicita de las esferas civil y religiosa. Se instituyó el puesto de Presidente Eclesiástico o Lector, con la finalidad de suplir el vacío de autoridad que implicó la desaparición de las atribuciones de los funcionarios del gobierno civil sobre el ámbito ceremonial. Este puesto implica la responsabilidad de exigir y vigilar el cumplimiento de las obligaciones de los mayordomos o cargueros. La disolución del ejercicio de la fuerza pública como acción legitima para el cumplimiento de los compromisos ceremoniales, ha dado lugar a una laxitud en la concepción de los cargos religiosos como un servicio obligatorio.

3.- En el año 1973 se estableció la primera denominación no católica en Atlahuilco, la denominación pentecostal La Luz del Mundo, en la localidad de Quechulingo. Como consecuencia de ello, se llevó a cabo un reacomodo

\footnotetext{
1 Como he mencionado, en algunos municipios de la Sierra de Zongolica, como Texhuacan y Tlaquilpa, las autoridades civiles sancionan aún el cambio de funcionarios religiosos en la ceremonia de fin de año.
} 
residencial: los conversos se establecieron en un sector de la localidad, después de sufrir durante algún tiempo la segregación social por parte de la población católica. En la actualidad, aproximadamente la mitad de la población de Quechulingo, profesa en la Luz del Mundo. ${ }^{2}$ Posteriormente, esta denominación se instaló en un paraje de la cabecera municipal sin conseguir hasta el momento la incorporación más que de unas cuantas familias. Más tarde se estableció el movimiento de Renovación del Espiritu Santo en las congregaciones de Quechulingo y Atlehuaya. Dado que en Quechulingo parte de sus habitantes profesan en la Luz del Mundo, la influencia de este movimiento dio lugar a que la localidad se escindiera totalmente de la participación en el sistema de cargos, puesto que ambas agrupaciones coinciden en cuestionar el ceremonialismo y el dispendio que impone el mismo. Por otra parte, en la cabecera municipal se estableció La Iglesia Cristiana Evangélica, a mediados de los años ochenta, consiguiendo paulatinamente la incorporación de algunas familias de los parajes de Tlalxitla y Atetzoc.

4.- Durante la última década se ha acentuado el papel de las capillas en algunas localidades del municipio. Si bien el ciclo ceremonial gravita en torno a la cabecera municipal, en términos espaciales, y en torno a la fiesta de San Martín, en términos temporales, el establecimiento de las capillas en las localidades establece una variación fundamental puesto que desencadena una organización del sistema con subsistemas satélites, con su propio calendario de fiestas asi sea sólo para una o unas cuantas imágenes. El número de habitantes de las congregaciones, con excepción de Zacamilola, oscila entre 60 y 350, factor que ha limitado el aumento en el número de cargos. Mientras que en Zacamilola, que cuenta con 1360 habitantes existen nueve mayordomias, en Atetocoxco, de 350 habitantes existe sólo una, y en Tambola y Tepexititla, pequeñas congregaciones de apenas 77 y 269 habitantes respectivamente no se cuenta con imágenes ni fiestas particulares.

El panorama religioso hoy en dia en Atlahuilco es de cierta pluralidad, con gradaciones en la intensidad de la participación de los pobladores de las congregaciones y rancherias en el ciclo anual de fiestas, y la deserción abierta de determinados sectores de población.

A la fiesta patronal celebrada en la cabecera -hasta hace pocos años una fiesta exclusivamente religiosa según mi propia observación- se han incorporado eventos seculares como elección de reina, baile popular, un torneo deportivo de alcance microregional, comercio y establecimientos de comida y bebida en el centro del pueblo. No obstante, el sistema de cargos religiosos para rendir culto a

2 Quechulingo cuenta con 239 habitantes, según el censo de población 1995, INEGI. 
las imágenes de los santos, continúa vigente en casi todas las localidades e involucra aún a la mayoria de sus habitantes.

Los sacerdotes en turno se han apoyado en dicha estructura para organizar las festividades importantes de la liturgia católica, aún cuando no siempre comparten la concepción de los nahuas en torno a las imágenes de los santos y el ceremonialismo en torno a ellas. En una entrevista reciente ${ }^{3}$, uno de los sacerdotes que ejercen su actividad pastoral en la sierra, expresaba su preocupación por las dificultades para comunicar la doctrina y los dogmas católicos a la población indigena. Desde su punto de vista, la barrera del idioma y las dificultades materiales para acercarse a las comunidades, impiden una comunicación eficaz con la población y por lo tanto, no es posible realizar la labor de evangelización desde una perspectiva de cierta profundidad. Si bien existen lineamientos generales para la realización de la pastoral indigena, los sacerdotes que han permanecido en la sierra durante las últimas dos décadas ejercen sus actividades de acuerdo a su posición e interés particulares en relación a la cultura y prácticas locales. Su presencia y posición al respecto no es homogénea; se han manifestado diferentes tendencias pastorales que sugieren que cuentan con un amplio margen de autonomia con respecto a sus superiores; en este sentido, su papel radica en gran medida en la actitud que asume cada uno de ellos hacia las expresiones de la religiosidad indigena (Chávez, 2000: 7374).

En ciertos casos se han realizado esfuerzos como el de traducir al náhuatl la celebración litúrgica e incorporar algunos elementos del ceremonial indígena como el uso de collares, copal y pétalos de flores durante algunos momentos del rito católico, asi como por participar de alguna forma en los rituales tradicionales asociados con el ciclo de vida y los sacramentos.

Sin embargo, en otros casos, la actividad de los sacerdotes se ha mantenido con mayor reserva en cuanto al interés en las concepciones locales y no se perciben intentos por adecuar su mensaje a la religiosidad indigena. Ello da como resultado una apariencia de pasividad entre los asistentes a la celebración de la misa, quienes muchas veces parecen no comprender los términos y conceptos que el sacerdote intenta transmitir. Durante mi asistencia a numerosos oficios religiosos tanto en Atlahuilco como en Tequila y Texhuacan, he observado la tendencia de los sacerdotes en turno hacia la tolerancia en relación a la realización de las mayordomias y la ritualidad festiva de los nahuas, sin embargo, atrás de ella se manifiesta una distancia y un cuestionamiento hacia la ingestión de alcohol y el gasto oneroso que ello implica. Además, se muestran consientes de que muchos aspectos de la doctrina no logran atravesar el tamiz de la cultura y tradición indígenas, como la idea de que el dios cristiano posee la

3 San Juan Texhuacan, 19 de agosto de 2000 
misma jerarquia que los santos católicos.

Por otra parte, los sacerdotes carecen de las posibilidades fisicas y materiales para llevar a cabo un contacto permanente con la mayor parte de las localidades que tienen asignadas en sus parroquias, de modo que asumen que excluyendo su labor en la impartición de los sacramentos, la población ejerce ciertos ámbitos de su religiosidad al margen de su presencia y participación. Es decir, reconocen que una serie de prácticas religiosas indigenas son absolutamente independientes de la estructura de la Iglesia católica, tanto en términos de creencias y visión del mundo, como en los aspectos institucionales del sistema de cargos. De ahi que desde su punto de vista, la evangelización en la sierra ha sido insuficiente (comunicación personal).

En la localidad de Atlehuaya, se ejerce un catolicismo influido por el Movimiento de Renovación Carismática. Este movimiento tiene escasa presencia en la sierra, según me ha expresado recientemente uno de los párrocos actuales, sin embargo, en este caso, se trata de la influencia de un grupo de catequistas vinculados a la localidad a través del municipio de Soledad Atzompa, otra puerta de entrada a la sierra, por la vertiente noroeste. Dado que esta pequeña localidad ha permanecido más vinculada geográficamente a dicho municipio, recibió el influjo de este grupo que cobró vigor hacia mediados de los años noventa. Este parece ser el único caso significativo en el municipio de Atlahuilco en que la participación de los catequistas ha creado una situación de competencia con el sistema de cargos, tal y como señala Garma (1987) que ha ocurrido en Ixtepec, comunidad totonaca. En el resto de las localidades, el papel de los catequistas quienes provienen de la parroquia de Tequila- si bien sirve también como enlace entre el sacerdote y la población y colabora en la organización de las actividades parroquiales, no interfiere en el desarrollo de las fiestas de mayordomia, controladas por el Presidente Eclesiástico y el grupo de mayordomos que cumplen su año de servicio.

En la actualidad, los habitantes de Atlehuaya se asumen como "hijos de San Martín", el patrono del municipio, asumiendo una forma de participación en la organización sociorreligiosa municipal en la que limitan su asistencia a los eventos culminantes de las fiestas de renovación de la cabecera. Es decir, han decidido ejercitar una forma de autonomia pero sin perder el vinculo de unificación con el conjunto, buscando el reconocimiento y aceptación del resto de los habitantes del municipio. Se presentan en el centro ceremonial durante las celebraciones importantes del calendario ritual para expresar su diferencia a través de una manera muy particular de cantar alabanzas religiosas.

Desde la perspectiva de los habitantes de la cabecera municipal, la localidad de Atlehuaya es considerada como una más de las que han adoptado un cambio de religión, es decir, la disidencia de su participación en el sistema de cargos así 
como ciertas similitudes en relación a la prohibición de beber alcohol y su postura critica hacia la fiestas de mayordomias, los equipara con los grupos que se han adherido a las denominaciones ro católicas, debido a sus prácticas de oración, de corte pentecostal, y a su negativa para participar de las fiestas de mayordomías, cuestionando especialmente la ingestión ritual de alcohol.

Es evidente que en Atlehuaya, este movimiento ha funcionado como un medio de fortalecimiento de la identidad comunitaria, la solidaridad local y la cohesión frente a los otros, especialmente frente a los mecanismos de control implicados en el sistema de cargos. Al mismo tiempo, esta unificación permite el planteamiento de demandas colectivas que en determinados momentos toman un cariz político. Desde mi punto de vista, y de acuerdo con lo señalado por Bastian, este neocomunitarismo evidencia que la comunidad continúa anteponiéndose al individuo, cuya identidad depende aún en gran medida de su inserción en una colectividad que se transforma en un nuevo actor social comunitario (1997: 214).

Como he mencionado, el sistema de cargos religiosos en Atlahuilco puede ser aún considerado como una jerarquía de prestigio, aún cuando no se trata de un sistema de escala, dado que cualquier hombre -y hoy en día casi también cualquier mujer- puede aspirar a la celebración de una mayordomia de las más importantes dentro del calendario anual aún sin haber realizado alguna otra de menor importancia. La ampliación de las posibilidades para la participación de las mujeres como responsables y capaces de asumir el puesto de mayordoma, es una de las nuevas adaptaciones del sistema, décadas atrás dirigido preferencialmente hacia los hombres adultos, quienes de este modo ratificaban su carácter de jefes de familia. Estos fungian como los responsables del cargo, aún cuando su gestión dependia del apoyo de su grupo doméstico y su círculo de parientes. Los jefes de familias recién escindidas de la residencia patrilocal, por ejemplo, asumian (como sucede aún actualmente) el cargo de mayordomo como una de las principales vias para la adquisición de reconocimiento social en su estatus adscrito. Aunque hoy en dia sigue vigente esta orientación en el carácter de la participación masculina, la participación femenina es parte de las adecuaciones recientes del sistema de cargos.

El establecimiento de capillas en algunas congregaciones, con sus consecuentes subsistemas de cargos religiosos dirigidos a sus propias imágenes, parece reforzar una tendencia creciente de descentralización de la cabecera municipal en la organización sociorreligiosa. Sin embargo, la existencia de las capillas y sus imágenes, no excluye necesariamente a los habitantes de las localidades respectivas de la participación en el sistema con sede en el templo de la cabecera; e incluso de su presencia y devoción incondicional durante las fiestas de renovación del centro ceremonial. Por otra parte, el establecimiento de un templo de La Luz del Mundo y de la Iglesia Cristiana Evangélica propician una 
nueva dimensión en los niveles de participación social, económica y de reclutamiento de grupos.

En el ámbito de la organización ceremonial, la autogestión está sirviendo como catalizador de las inquietudes e intereses de los segmentos territoriales, como he argumentado en otra parte del trabajo. A través del establecimiento de capillas y otras organizaciones religiosas como La Luz del Mundo, se persigue la afirmación de estas localidades dentro de la arena social. Es decir, el surgimiento de estas denominaciones ha proporcionado el camino para obtener cierto reconocimiento social creando nuevos roles de prestigio, los cuales, al mismo tiempo permiten una mayor expresión política, como señala Garma para el caso de Ixtepec (op. cit.: 163). Sin embargo a diferencia de lo que plantea este autor, en Atlahuilco es dificil afirmar que los adeptos a dichas agrupaciones puedan ser ubicados en los estratos medio y alto, aún cuando argumentan que las fiestas de mayordomias y la ingestión de alcohol empobrecen a los cargueros y redundan en el menoscabo de su bienestar y economia familiares. Es decir, no resulta tan evidente que los integrantes de las agrupaciones no católicas conformen un grupo claramente en ascenso en términos de sus capacidades económicas, a pesar de que han mostrado su capacidad para transformar las vias de participación en las estructuras politicas locales.

No obstante, al igual que en Ixtepec, el surgimiento de estas agrupaciones se vincula con la crisis del sistema de cargos como el medio privilegiado para la adquisición de prestigio y para la participación en las esferas de la vida pública, asi como con el cuestionamiento del poder político hacia los grupos de poder asentados en la cabecera, quienes habian fungido hasta hace pocos años como los intermediarios entre los sectores locales y los regionales. Es decir la aparición de estos grupos ha debilitado en cierta medida los patrones tradicionales de liderazgo, en concurrencia con otros factores como señalo a continuación.

\section{b) Etnicidad, ritualidad y cambio adaptativo.}

En Atlahuilco se manifiesta un acervo de variabilidad entre las generaciones, que posibilita un "cambio adaptativo", dirigido hacia la realización de ajustes frente a las distintas presiones de que la región es objeto (Lewellen, 1985: 59-72). Es evidente en distintos pueblos de la sierra, especialmente en Texhuacan, Tlaquilpa, Tequila y Atlahuilco, un intenso dinamismo en cuanto a las posiciones de los jóvenes en relación al ejercicio de la religiosidad y respecto a su entorno social y cultural. Se aprecia una inquietud por ganar un espacio en el seno de una sociedad nacional fundamentalmente asimétrica, en la cual se reconozcan y respeten las diferencias. Desde mi perspectiva, las distintas posiciones responden a la alienación de dos necesidades opuestas: la de mantener y preservar la identidad étnica y las diferencias culturales, por una parte, y la de 
participar de los beneficios que proporciona la participación en la sociedad hegemónica, por la otra. Esta alienación de necesidades responde a la relación de asimetria que caracteriza la inserción de los pueblos indigenas dentro del Estado-Nación.

En este contexto, algunas agrupaciones de maestros bilingües y jóvenes intelectuales manifiestan, por ejemplo, un interés en la revitalización lingüistica, fomentando la lectura y escritura del idioma náhuatl con el apoyo de instancias gubernamentales como la radiodifusora indigenista, a cargo del Instituto Nacional Indigenista. Han organizado talleres dirigidos hacia el aprendizaje y estandarización del idioma y han participado en los programas impulsados por las instituciones encargadas de promover la cultura como la Dirección General de Culturas Populares y el Instituto Veracruzano de Cultura, en las que se promueve la creación literaria en lenguas indigenas y registros de la narrativa y tradición oral. Otros esfuerzos de estas agrupaciones civiles se dirigen hacia la búsqueda y reivindicación de los origenes, dando lugar por ejemplo, a la formación de grupos de danzas autóctonas apoyados en las imágenes y atuendos de las culturas prehispánicas, o la escenificación de rituales como el xochitlali, con la pretensión de conseguir la mayor fidelidad y autenticidad.

En Atlahuilco, se manifiesta entre los jóvenes una posición menos centrada en el detalle etnográfico y más encaminada hacia cuestiones relativas a la sobrevivencia. Esta actitud se refleja en acciones concretas que expresan un deseo de cambio, mediante un manejo consciente de la etnicidad pero con intenciones de ascenso social sin filiaciones politicas partidistas. Ello se expresa por ejemplo en la lealtad y orgullo hacia la lengua, en una reivindicación de los orígenes y en un deseo de dignificación de las condiciones de vida. Desde su perspectiva, esto es posible asumiendo determinados valores locales, pero intentando rebasar los alcances de la organización comunal en torno a la ritualidad festiva. Su afirmación se configura pues como parte de un proceso de negociación con la sociedad hegemónica y con quienes, en la escala local, detentan el poder político y económico, aún tratándose de las instituciones tradicionalistas como el sistema de mayordomias. Es decir, pareciera haber una aceptación de la diferencia étnica pero no necesariamente de las relaciones asimétricas como su consecuencia.

De este modo, miembros de las primeras generaciones de jóvenes alfabetizados, algunos con estudios de enseñanza media, buscan un espacio para dar cabida a la cristalización de cierta independencia de las instituciones culturales, incorporando nuevas vias, como la integración de equipos deportivos, el comercio y los talleres artesanales; exploran perspectivas de autodesarrollo sin emigrar de la localidad, tratando de establecer otros mecanismos de ascenso social. Se han organizado, por ejemplo, algunos grupos para trabajar en cooperativas, en las que con muy poco capital establecen pequeños comercios y 
talleres de carpinteria, asociándose en grupos que pueden constar desde tres hasta quince o veinte personas. Manifiestan una suerte de desencanto acerca de los partidos politicos y de las instancias gubernamentales, enorgulleciéndose de su autonomia y capacidad de autogestión. Un grupo de jóvenes de Cuautlamanca, por ejemplo, instaló una carpinteria, con herramienta eléctrica y un molino de nixtamal, reinvirtiendo su pequeño capital y generando sus propios empleos. Si bien parte de estos esfuerzos han sido propios, algunas de estas cooperativas se han realizado con apoyo de programas estatales como el de "Fondos Regionales" manejado por el Instituto Nacional Indigenista.

Por otra parte, en la gestión de proyectos productivos implementados a través de programas oficiales, han ganado ventaja quienes manejan más elementos del discurso y los procedimientos de la burocracia indigenista y han llegado a conformar una especie de clientela fija para la recepción de créditos, apoyos, presentación de proyectos, aparición en los actos públicos, etc., beneficiándose de la mayoria de los programas impulsados por el Estado. Destacan algunas familias de la cabecera municipal y de Zacamilola en este tipo de gestiones, mientras que otras pequeñas localidades como Tepexititla y Tambola se caracterizan por un alto grado de analfabetismo, los más bajos niveles de subsistencia y una escasa participación en actividades de esta naturaleza.

Existen pues actitudes claramente definidas en sectores de las nuevas generaciones que podrian considerarse expresiones de una ideologia de progreso y de orgullo lócal, de construcción de un nuevo discurso comunitario, en cual se retoman algunos marcadores de la etnicidad como la lengua, para adaptarse y resultar competitivos en el contexto extralocal. En esta elaboración, se maneja la tradición no como continuidad del pasado, sino como su redefinción en función de las necesidades y desafios del presente (Giménez, op. cit.: 20), expresando al mismo tiempo una concepción cívica y secular, encaminada hacia el ascenso económico. Desde mi punto de vista, se trata de una combinación entre mecanismos comunalistas de reciprocidad con un proceso de legitimación de las intencionalidad individual; una recepción mediada entre la experiencia de la organización comunal y el uso de elementos del paisaje cultural nacionalista y sus procesos económicos y politicos. Se conforman de este modo estrategias de asociación sustentadas en una ética distinta a la de la comunidad agraria, configurada por normas rigidas de cohesión e interdependencia, y con un campo estrechamente circunscrito para el desarrollo de intereses individuales.

Evidentemente, tras estos intentos, se busca cambiar un estado de cosas, que ha obligado a generaciones de hombres y mujeres a emigrar durante largos periodos de su vida hacia las plantaciones de las tierras cálidas y templadas. Ello no implica, que haya cesado este movimiento, aún claramente acentuado entre las capas más pobres, respuesta común a las presiones sobre los recursos y el crecimiento demográfico. En esta búsqueda de alternativas se ha recurrido 
también a la carpinteria y la venta de tablones, leña y carbón, con serias consecuencias sobre los recursos forestales.

Al interior de Atlahuilco, como en el resto de los municipios serranos, se manifiesta una diferenciación social creciente. Desde mi punto de vista, este proceso se agudizó a partir de la utilización de los recursos forestales con fines de comercialización. Fue en las localidades de Tepexititla y Zacamilola donde se inició el trabajo de carpinteria en talleres domésticos en los que se utilizaban herramientas manuales elementales, hacia principios de los años noventa. Los productos, tablones y muebles de acabados excesivamente rústicos, se cotizaban a muy bajo precio en el mercado urbano, pero su elaboración y venta permitia una forma más rápida de proveerse de ingresos monetarios mediante un trabajo menos penoso que el de las fincas y las plantaciones. Paulatinamente, la producción de muebles se ha diversificado y mejorado la calidad, dado que se ha incorporado la utilización de herramientas más eficientes, como sierras eléctricas y tornos.

La explotación de los recursos del bosque incide en una pérdida paulatina de la masa forestal, la cual es ya inexistente en determinadas áreas de la Sierra de Zongolica, especificamente de los municipios de Tehuipango, Astacinga y Xoxocotla. Al mismo tiempo ha desencadenado un proceso de intermediarismo y acaparamiento de los productos generados, especialmente en las cabeceras de los municipios de la zona fría de la sierra, dando lugar a la la intensificación de la economía monetaria y la acentuación de las diferencias sociales.

En este mosaico, resulta evidente que los pobladores de las localidades y parajes de Atlahuilco seleccionan las prácticas y ofertas exógenas para conformar sus propias estrategias frente a la sociedad hegemónica y frente a las presiones intracomunales. Así por ejemplo, mujeres de Quechulingo, Tepexititla, Tambola y Atlehuaya, se esfuerzan por atravesar la frontera del monolingüismo, realizando un esfuerzo por comunicarse, cuando es necesario, en un castellano que se habia mantenido en el nivel de dominio pasivo. Asi mismo, presionadas por la pobreza y las carencias materiales, se han movilizado utilizando los elementos que les proporciona su propia cultura: el tejido en telar de cintura y la elaboración de enseres de barro. ${ }^{4}$

\footnotetext{
4 A través de un proyecto impulsado por la Dirección General de Culturas Populares, desde hace aproximadamente diez años se ha estimulado a las artesanas a mejorar la calidad de sus textiles y enseres de barro. Algunas artesanas han incursionado en los mercados urbanos y en las salas de exposiciones artesanales. Si bien los beneficios económicos a partir de esta actividad, son apenas incipientes, ello ha representado una experiencia valiosa para las mujeres nahuas en términos tanto de sus prerrogativas en el seno de la unidad familiar, como en cuanto al manejo de nuevas perspectivas para la obtención de ingresos complementarios.
} 
Motivaciones de carácter económico y político, constituyen el marco para la diferenciación religiosa y las posiciones diversas en relación al catolicismo ceremonial del sistema de cargos. Sectores de jóvenes de la cabecera municipal, asi como de Cuautlamanca y Atetkoxko, las localidades más próximas al centro ceremonial, rechazan la idea de asumir los costosos compromisos como anfitriones de las fiestas, argumentando que para ello es necesario deshacerse de parte de sus escasos bienes. Sin embargo, manifiestan fervorosa devoción al santo patrono, ratificando su carácter de emblema del pueblo y asistiendo con entusiasmo a las fiestas de renovación del centro ceremonial, y desempeñan incluso papeles protagónicos como el de Apóstoles durante la celebración la Semana Santa. Esta postura permite su actuación en el escenario público ritual, en una festividad en la que convergen pobladores de todo el municipio, consiguiendo de este modo la presencia en la vida pública y ritual del pueblo, pero desde una posición de critica hacia el dispendio y la libación excesiva.

En el cuestionamiento hacia las formas tradicionales de celebrar las fiestas de mayordomia, en el rechazo al consumo excesivo de alcohol y en el deseo de prosperar económica y materialmente, es posible apreciar, por lo menos, una doble influencia que se agrega a las tensiones intraétnicas: por un lado la de una educación formal que, aunque elemental, implica un adiestramiento en manos de individuos que no pertenecen -o no siempre- al grupo local y que proporciona fundamentos y escalas de valores que los capacitan para asumir otros puestos en la sociedad (Gellner, 1991: 55). Por otra parte, la que se refiere a la prédica de sacerdotes y catequistas, quienes se manifiestan en desacuerdo con el excesivo ritualismo que implican las fiestas dedicadas a las imágenes de los santos, e intentan propagar una fé más fincada en el fervor cristiano del catolicismo postconciliar.

Resulta significativo el énfasis con que un amplio sector de jóvenes de Atlahuilco, de distintas localidades y filiaciones religiosas se pronuncia por la moderación en el consumo de alcohol; refieren que en las localidades más pobres y apartadas del municipio, Tepexititla y Tambola, niños, hombres y mujeres inician la jornada con un trago de aguardiente, antes de empezar a sentir el hambre y el agotamiento fisico.

Bastian interpreta el rechazo al alcohol y a la celebración de las fiestas del calendario ritual, como una opción que busca la autonomia simbólica dirigida a impedir el "sistema de expotación ligado a la fiesta politico-religiosa" (op. cit.: 112). La tendencia hacia la reformulación del sistema de cargos, seria, desde esta perspectiva, una respuesta de las jóvenes generaciones para quienes el financiamiento de las fiestas resulta cada día menos asequible. La abreviación del ritual y el cambio religioso se expresan pues como una mediación dinámica, frente a los conflictos que se presentan en un momento de cambios acelerados en el desarrollo regional. Es posible plantear la idea de que el cambio religioso 
mediatiza formas opuestas de entender el mundo de las personas y de los bienes (Taussig, 1993: 36), en un momento crucial en la definición de las fronteras.

Si bien la conversión religiosa puede leerse desde esta perspectiva, es decir, como un medio para controlar la ansiedad ante una situación de cambio que las tradicionales prácticas rituales no son capaces de controlar, se presenta un fenómeno que puede sugerir que en determinados contextos, el cambio religioso no está resolviendo las expectativas profundas de los convertidos, o bien, como señala Bastian, en ocasiones los actores sociales recurren a distintas ofertas relgiosas según las etapas de su vida y de acuerdo a las coyunturas que se les presentan (op. cit: 209). En Atlahuilco, algunos hombres, después de profesar en La Luz del Mundo, han vuelto al culto católico, pero ya no adhiriéndose a la versión ceremonial del sistema de cargos, sino como elocuentes catequistas de la parroquia. El libre acceso a la prédica otorga, según Bastian, la posibilidad de transformarse en actor social. Los catequistas -según testimonios del propio sacerdote de la parroquia de Tequila, tienen la misión de dirigir un cambio paulatino en la concepción de la religiosidad indigena, en el marco de la liturgia católica post-conciliar, con un enfoque que cuestiona las prácticas ceremoniales relacionadas con el sistema de cargos, asi como otras formas de conducta que a su juicio atentan contra la integridad familiar, especialmente en relación al adulterio, la poligamia y el alcoholismo.

No obstante que ciertos sectores de población, especialmente algunos jóvenes, prestan atención a estos discursos, existe un amplio sector que podriamos llamar tradicionalista, que decide permanecer ajeno a estas versiones que, además de incidir en el desarrollo de las fiestas, cuestionan prácticas como la poligina y la libación, las cuales se manifiestan en menor o mayor grado dentro del grupo de los cargueros.

Este proceso de transformación de una ideologia fincada en los principios de organización de la comunidad corporada, se expresa en otra paradoja: por una parte, una actitud de competencia y rivalidad individual y por otra, un predominio de la unificación como localidades y agrupaciones residenciales ante la emergencia. Asi por ejemplo, la gente de Zacamilola y Tepexititla se ha manifestado durante los últimos años, a veces en tono beligerante, para exigir el cumplimiento de compromisos contraidos por parte de las instancias de gobierno estatal, o bien, para evitar lo que consideran agresiones para sus intereses colectivos. Se ha cuestionado severamente tanto a los actores locales inmiscuidos en el gobierno municipal, como la intervención de las agencias del Estado, llegando incluso a las agresiones fisicas.

Durante la última década, la participación en organizaciones políticas independientes ha permeado también las posiciones de habitantes de las rancherias de Atlehuaya, Tepexititla y Tambola, impugnando a los 
representantes del partido oficial y proponiendo a sus propios candidatos en las contiendas electorales. De este modo, se ha evidenciado una politización de los habitantes de las congregaciones, quienes afiliados o no a alguna organización de este tipo, se manifiestan de forma definitiva en la organización y canalización del conflicto político. Estos eventos pueden ser interpretados desde el punto de vista de Eisenstad, quien señala que el núcleo común de los procesos de modernización son la diferenciación y la movilización sociales; la esfera política debe diferenciarse suficientemente de la esfera religiosa para realizar los ajustes necesarios al constante cambio que supone dicho proceso, socavando incluso las lealtades sociales y psicológicas tradicionales para posibilitar formas nuevas.

Si bien durante los años ochenta y principios de los noventa, un grupo de maestros de primaria residentes en la cabecera municipal pero con vínculos extralocales, controló el escenario político de manera abierta, las últimas dos gestiones municipales han estado a cargo de macehuales, campesinos nahuas procedentes de las rancherias más apartadas como Acultzinapa y Atlehuaya, elegidos como una reacción de rechazo hacia dicho grupo y en defensa de sus propios intereses. Ha sido, por lo tanto, evidentemente amenazada la base del poder politico de la clase social emergente durante las dos décadas pasadas, desencadenando tensiones sociales en la lucha por el poder, en la cual los nuevos gobernantes indígenas parecen haber incorporado algunos valores de aspiración politica y enriquecimiento material.

Esperaban que si "un macehual, un campesino como nosotros" se hacia cargo de los asuntos del municipio, se retomaria el control sobre el espacio comunitario y podria aspirarse a un mejoramiento de las condiciones materiales de vida. Aunque los resultados hasta ahora no han sido del todo satisfactorios, se ha reivindicado el ejercicio de la autoridad por parte de quienes se consideran macehuales, independientemente de la filiación religiosa o de su participación como anfitriones de las fiestas del ciclo ceremonial, otorgando de este modo un valor de autenticidad a las aspiraciones politicas de los habitantes de las rancherias. En la gestión actual, el puesto de presidente municipal es ocupado por un miembro de la Iglesia Cristiana Evangélica. Se consolida pues, al parecer de forma definitiva, la separación entre la estructura de la organización religiosa de los asuntos del gobierno civil.

Lo cierto es que hoy en día parece existir una ética en transición, desde una posición de una sociedad igualitaria que -tal y como lo interpreta Taussig para los mineros de Sudamérica "quita legitimidad a aquellas personas que ganan más dinero y tienen más éxito que el resto del grupo social" (op. cit.: 32), hacia una forma de avalar la prosperidad individual. En este proceso de diferenciación social y económica se manifiesta una apertura hacia la libertad de acumulación, en conflicto con la censura y los conflictos interpersonales, es decir no se puede afirmar que se haya realizado un cambio radical hacia un modelo de 
individualización y racionalización económica.

Este proceso de intermediarismo entre localidades, municipios, región y Estado, está dando lugar a una organización local heterogénea como resultado de no pertenecer a una red basada exclusivamente en las relaciones parentales y aquellas implementadas a partir del sistema ceremonial. En el campo de la religiosidad, los pobladores de Atlahuilco se enfrentan a diversas contradicciones que expresan los deseos e intereses divergentes en la búsqueda por cambiar el orden social dominante. Se trata, de "procesos de reflexividad", en que las facciones aspiran a alterar las formas de existencia, como sujetos activos que buscan definirse a si mismos, dada la naturaleza del proceso conflictivo en el cual participan (Diaz, 1997: 11), elaborando discursos en los cuales se entretejen elementos de distintas tradiciones.

Por otra parte, se manifiestan también con vitalidad las nociones de los cargueros y funcionarios de la iglesia, quienes alimentan la devoción colectiva fijada por las tradiciones locales, parte fundamental de la experiencia común. $\mathrm{Su}$ influencia en la arena social se trasluce en un reforzamiento implícito del ritual comunalista, y evidencia una ausencia de acuerdos claros acerca de las mediaciones necesarias y oportunas en la orientación de un proyecto colectivo. Es decir, por una parte se reconoce la importancia de otorgar respeto y reverencia al acervo ritual y por otra, se busca la revitalización de la organización local incorporando nuevos discursos que descubren las relaciones asimétricas.

Este proceso de heterogeneización social no excluye, sin embargo, la búsqueda de un nuevo referente totalizante. En esta búsqueda, la imagen de San Martín continúa funcionando como emblema, otorgando una imagen de unidad y en tanto sigue vigente una pauta cultural en la cual se implementan tareas comunes establecidas por una tradición de devoción colectiva. Como señala Giménez (op. cit.: 23), las imágenes de los santos patronos son inseparables de la historia de los pueblos indigenas, de la memoria de sus antepasados y de sus origenes en el tiempo, como consecuencia de ello, dificilmente se sustituye su función como referente colectivo y de convergencia de un serie de relaciones sociales. Los nuevos movimientos religiosos dan lugar a afirmaciones comunitarias nuevas y reconstituyen lazos comunitarios en ámbitos restringidos del territorio municipal, favoreciendo la multiplicación de actores politicos.

En esta redefinción se busca pues el reconocimiento de la propia identidad minorizada y estigmatizada, en el marco de un proceso de etnicización impulsado por el estado y la sociedad dominante y asumido por las propias minorias étnicas. La dinámica local contemporánea implica así procesos locales de profunda historicidad -como el ritual comunalista del sistema de cargos y de cuotas de trabajo- con propuestas innovadoras de desarrollo comunal. 
La experiencia contemporánea de los nahuas incluye, en sintesis, la ausencia de acuerdos acerca de los medios y fines de interés colectivo. Las diversas posiciones podrian ser esquemáticamente agrupadas entre quienes se definen por el perfeccionamiento y conservación del proceso ritual y quienes se inclinan por la promoción de la base extralocal reinvindicando la herencia étnica. Estos descuerdos responden parcialmente al hecho de que existe un sector de población -cada vez mayor-familiarizado con la actuación hacia fuera del propio territorio. Mientras tanto, continúa en vigor el esquema fijado por la tradición de devoción colectiva y de cuotas comunalistas, el cual es puesto en práctica por un amplio sector de la población. Desde mi punto de vista, esta variación sugiere que no existe una interpretación dominante en la definición de los vínculos entre las relaciones a escala local y las de escala extralocal. 


\section{COMENTARIOS FINALES}

Hacia fines de la década de los setentas, incursioné por primera vez en la sierra de Zongolica, como estudiante de la Facultad de Antropologia de la Universidad Veracruzana. En ese entonces, el acceso a la mayoria de los poblados y rancherias nahuas -con excepción de los pueblos de Tequila y Zongolica- se realizaba a pie; las mercancias se trasladaban de uno a otro punto a lomo de bestias de carga y no llegaba aún la energia eléctrica, el teléfono, ni el agua entubada. Aunque se encontraban algunas aulas de educación primaria en las cabeceras de los municipios enclavados en la serrania, no se contaba con servicios médicos, ni de abastecimiento más que de los viveres más elementales.

En aquella época, el clima imperante en las aulas de nuestra clase se dirigia hacia la reivindicación del quehacer etnográfico y de la antropologia como disciplina, cuando aún estaba presente entre algunos de nuestros condiscipulos y maestros un enfoque que cuestionaba el papel de los antropólogos como servidores del proyecto indigenista nacional, y subrayaba el interés por entender a los indios de México como pertenecientes a una clase social explotada, los campesinos, a quienes debiamos acercarnos para entender no sus diferencias culturales, sino su condición de clase. Se reflexionaba acerca de la relación entre la antropología y los imperativos de la politica del Estado mexicano en torno a los indios, la cual planteaba la necesidad de su integración al concierto de la sociedad nacional. La tensión entre lo indio y lo nacional generaria diferentes planteamientos teóricos y politicos en la antropologia mexicana desde su nacimiento en la primera mitad del siglo XX (Medina, 1996b: 15).

A raiz de la crisis de 1968 , emergió una profunda critica hacia el vínculo estrecho entre la investigación antropológica y las acciones indigenistas del estado mexicano (op. cit.: 31). En esta coyuntura se expresaron diferentes posturas de impugnación y de apoyo al indigenismo, las cuales tomaban forma en un contexto que trascendia el escenario nacional, y en el cual se discutia el papel de los antropólogos en los procesos de colonización y su responsabilidad como cientificos sociales. Los estudios sobre el campesinado habian ocupado un lugar prominente en la antropologia mexicana, a partir de la irrupción del pensamiento marxista en la disciplina; en ellos se privilegiaba el estudio de la estructura o esfera económica y la relación de explotación entre las clases de la sociedad capitalista (Krotz, 1993: 14-15). Este enfoque planteaba que era de mayor interés comprender la condición de clase del campesinado que sus aspectos "superestructurales". Los grupos indigenas eran ubicados dentro de la categoria de campesinos y se consideraba que su situación étnica y cultural formaba parte de la esfera ideológica. Se criticaba también a los estudios de comunidad que se habian realizado durante las dos décadas anteriores, en los cuales se interpretaba a la realidad 
indigena como unidades de análisis autocontenidas, homogéneas y aisladas de las problemáticas regional y nacional.

Como contraparte, se proponia el acercamiento a los pueblos indios desde una perspectiva macrosociológica que se apoyaba en la teoria de la dependencia, en el análisis de los efectos del imperialismo y en las tesis del colonialismo interno. Se dejaron de lado temas que abordaban la antropologia social británica y la antropologia cultural norteamericana, por sus supuestos vinculos con el "imperialismo cultural", y temas clásicos de la antropologia como la religión y el parentesco (Krotz, op. cit.: $17-18)$.

La transición hacia el estudio de la cultura se realizaria hacia fines de los setentas a través de los" trabajos de-Gramci y de otros autores que retomaban el concepto de cultura desde la perspectiva de este autor, como Lombardi Satriani y Cirese. Este retorno a los aspectos "superestructurales" no implicaba sin embargo el regreso a los enfoques clásicos de la antropologia, sino la modalidad de su estudio bajo el concepto general de "cultura popular", noción que permitia dar cuenta de particularidades etnográficas y problemáticas concretas de distintos sectores de las capas populares, y al mismo tiempo posibilitaba su análisis dentro del marco teórico marxista (Krotz, op. cit.: 20). Este cambio de rumbo propició la apertura hacia otros campos que habian sido relegados de la investigación antropológica. Se retomó el interés por una diversidad de temas de la cultura popular como la religiosidad, la medicina, los procesos productivos de la agricultura y las artesanías, la narrativa, y las identidades colectivas, entre otros. De este modo, el concepto de cultura en la antropología mexicana comenzó a utilizarse en conexión con un determinado adjetivo. Acusa una importancia clave en los trabajos de las dos últimas décadas, en los cuales se privilegian aspectos más ligados a la construcción de identidades y a la interpretación de la culturas particulares, dejando atrás las explicaciones apoyadas en las grandes teorias (Krotz, op. cit.: 10).

Con el desmoronamiento de las lineas de pensamiento radicales como el marxismo, y al centrarse más en el estudio de los universos simbólicos, en la formación de identidades, en la heterogeneidad étnica y cultural, en las expectativas, demandas y derechos de los actores sociales y grupos marginados, la antropologia incorpora hoy en dia conceptos y orientaciones que incluyen la visión de los propios actores. En estos enfoques han tenido considerable influencia la corriente interpretativa, la hermeneútica, y la antropologia simbólica.

Es en este contexto intelectual que se manifiesta entre algunos miembros de mi generación, un interés por retomar la especificidad de la antropologia como disciplina. Regresamos a la lectura de los trabajos clásicos que alimentaron el pensamiento etnológico a partir de la primera mitad del siglo XX, como las obras de Marcel Mauss, Claude Levi-Strauss Bronlisaw Malinowski, Evans Pritchard y muchos otros, de donde 
rescatábamos la concepción acerca del trabajo de campo como la vía privilegiada para entender la realidad. En consecuencia, las discusiones en torno a las distintas escuelas de pensamiento antropológico y el interés en el refinamiento de las técnicas de investigación de campo, sustituyeron la lectura de El Capital y de otros textos, cuyos autores sustentaban sus análisis bajo la perspectiva del materialismo histórico.

Reflexionábamos acerca de las implicaciones profundas del trabajo de campo desde el punto de vista teórico, es decir como la práctica que construye el puente entre la experiencia y la teoria (Lomnitz, 1999: 90). Por otra parte, nos interesaba también la dimensión subjetiva de las motivaciones personales que inevitablemente permean nuestra visión de "los otros". Ejerciamos de este modo, una posición de cierta reserva hacia las pretensiones de construir el conocimiento antropológico desde una mirada dogmática, esterilizada y con pretensiones de absoluta objetividad.

En términos generales se podria resumir quizás ese momento, como el intento por entender el quehacer antropológico desde una posición más atenta a las tensiones que se dan entre nuestros alcances y limitaciones como investigadores, las realidades locales que estudiamos, la influencia del Estado y la perspectiva de los propios actores. La crisis de las grandes ideologias y la critica al IIuminismo y a la idea de modernidad y progreso, daria lugar a una antropologia que empezaria por asumir que únicamente es posible entender fragmentos de la realidad. Se desarrollaria asi el escepticismo hacia ciertas categorias analiticas a partir de la influencia de autores postestructuralistas como Foucault y Derrida. De éstos autores se lega a la antropologia posmoderna la oposición a los grandes sistemas de pensamiento occidentales. Se percibe el influjo de un escepticismo hacia la autoridad del trabajo etnográfico y un sentimiento de crisis de la disciplina que tomaria fuerza en Estados Unidos hacia mediados de los ochentas con los antropólogos posmodernos después del auge de la corriente interpretativa. Estos se proponen analizar los recursos de la etnografia y de tipificar nuevas alternativas de escritura etnográfica; proclaman la crisis de la ciencia y abogan por una redefinición de la práctica antropológica ((Reynoso, 1991: 17-28).

De modo que mi primer encuentro con los nahuas resultó fundamental para mi experiencia personal y profesional puesto que representó, de hecho, mi primer enfrentamiento con la alteridad. A partir de entonces se fue gestando en mi un genuino interés en la zona, y una creciente familiaridad que alimentaria durante mucho tiempo mis nexos con sus habitantes.

Algunos años después, hacia 1983, siendo ya pasante de la licenciatura, se me presentaria la oportunidad de regresar al mismo lugar donde realicé aquella primera práctica de campo, formando parte de un proyecto implementado por el entonces naciente CIESAS-Golfo, a cargo del Dr. Gonzalo Aguirre Beltrán. Hasta ese momento se contaba 
solamente con unos cuantos trabajos de investigación acerca de la zona, fundamentalmente tesis de licenciatura en las que predominaba un enfoque basado en las posturas téoricas en boga durante los años setentas, el enfoque campesinista y la perspectiva del materialismo histórico (Jácome, 1972; Barjau, 1972; Foladori, 1975; López Arellano, 1977), además de una descripción etnográfica del pueblo de Tequila, realizada por Georgette Soustelle y publicada en francés en 1958, y una investigación de Daniel K. Early (1982) acerca de la producción del café en las comunidades de las zona templada de la sierra.

El Dr. Aguirre Beltrán consideraba conveniente la integración de equipos de investigadores que abordaran exhaustivamente, una a una, las regiones interétnicas veracruzanas. De esta manera se inició el estudio del "Uso y desuso del náhuatl en la sierra de Zongolica", como primer proyecto de investigación del CIESAS-Golfo, en el cual participamos cuatro becarios, dirigidos por los investigadores fundadores de la unidad, incluido el Dr. Aguirre Beltrán. Comenzó entonces una fase de estudios sobre la región que dio como resultado distintas investigaciones que salieron a la luz en forma de tesis de licenciatura y algunos libros, entre ellos, dos trabajos del propio Dr. Aguirre Beltrán (1986 y 1995).

Al interés inicial en la lingüistica y la sociolingüistica ${ }^{1}$, continuaron investigaciones en la línea de la medicina tradicional, la ritualidad y otros aspectos de organización social. Fuera del CIESAS-Golfo se gestaba cierto interés en la sierra de Zongolica por parte de algunos egresados de la Universidad Veracruzana que presentarian sus trabajos de tesis de licenciatura en el curso de la década de los noventas. Además de la tesis doctoral realizada por la investigadora alemana Brigitte Hülsewiede (1992 y 1998) en el municipio de Tequila.

De este modo, mi retorno a la sierra se fue centrando hacia intereses de investigación especificos. El primer resultado fue precisamente la tesis de licenciatura (publicada en 1988), basada en la aplicación de una técnica etnográfica, el levantamiento de genealogias lingüisticas, metodologia que me permitió entender el proceso de transmisión del náhuatl en Texhuacan, una localidad bilingüe. ${ }^{2}$ En trabajos posteriores abordé cuestiones relativas a las dinámicas regionales, la organización social, la ritualidad y otros temas generales. ${ }^{3}$

\footnotetext{
- Se realizaron los siguientes trabajos respecto a estas temáticas: Alarcón, 1986; Hasler, 1987 y 1996; Luna, 1988; Monzón, 1990; Paniagua, 1986; Rodríguez, 1988; Roth Seneff et.al., 1986; Roth Seneff y.Monzón, 1985; Torres, 1987; Yopihua, 1992.

2 Esta investigación fue dirigida por el Dr. A. Roth Senneff, quien me instruyó en la aplicación de este método, y en la posterior sistematización de la información para modelar el sistema de transmisión de la lengua vernácula en condiciones de asimetría lingüistica.

3 Alvarez y Rodriguez, 1991 y 1992; Rodríguez, 1993,1995, 1995b, 1995c; Rodríguez y Hasler (en prensa).
} 
A lo largo de mis incursiones por la sierra me he percatado no sólo de los cambios más evidentes, como el hecho de que hoy en dia un gran número de localidades cuentan con energia eléctrica, agua corriente, algunos caminos transitables, escuelas y otros servicios. Esta perspectiva de veinte años de acercamiento a la región me permite contar con una visión de relativa profundidad, en cuanto a las forma en que los pueblos nahuas han asumido los retos impuestos por los acontecimientos recientes en el concierto nacional, y en relación a las políticas indigenistas y la globalización, asuntos que abordo brevemente en el siguiente apartado.

\section{Indigenismo, globalización e ideologias locales.}

En Nueva España, durante los primeros años de la colonia, los ojos europeos ponian en duda la pertenencia de los indios a la común humanidad, cómodo pretexto y puntal lógico para el ejercicio del dominio y supremacia (Gerbi, 1982: 83). Sin embargo su naturaleza humana habria de ser indispensable para argumentar la necesidad de evangelizarlos, reconociendo su corrupción natural, el pecado original innato en todo ser humano. Colocando al hombre en el centro del cosmos, los pensadores renacentistas consideraron que faltaba a los americanos el arbitrio moral de la Iglesia y de la doctrina católica romana y los estatutos politicos que avalaban la autoridad de la monarquia.

Los racionalistas, por su parte señalaban que el hombre se encuentra dotado naturalmente de un espiritu bondadoso. Paralelamente a la ideologia del noble salvaje, se expresaban también la nociones de su inferioridad espiritual y moral y de debilidad corporal, mismas que servirian tanto a los detractores del indio, como a sus protectores, especialmente a fray Bartolomé de Las Casas, quien abogaba para que se les dispensara de las penosas fatigas y despiadadas jornadas a que era sometida la población nativa (Gerbi, op. cit.: 86 ). Durante el siglo XVIII, las posturas en cuanto a la naturaleza y cualidades fisicas del indio variaban de acuerdo a las exigencias de las polémicas que desarrollaban los ideólogos de la Ilustración, y a conveniencia de los intereses de los colonizadores. Coincidian en el convencimiento de su misión civilizadora tanto los evangelizadores como los iluministas. Sin embargo, para estos últimos, no era del todo necesaria la tutoria del Estado y de la Iglesia, puesto que su absoluta fe en el progreso y en la fuerza de la razón, implicaba el reconocimiento de la población colonizada con las capacidades innatas a su naturaleza humana. Esta mirada seria un punto de partida para el razonamiento evolucionista

Los elementos de la filosofia política del Siglo de las Luces encontraron acogida entre los criollos americanos, prontos a modelarse sobre los nuevos esquemas. Los criollos incorporaron a los valores de la Ilustración que favorecian los movimientos nacionales y que darian lugar al despertar de la idea de nación independiente como alternativa posible (Lafaye, 1985: 177-178). En este devenir, los pueblos indios continuaron siendo 
un obstáculo para el progreso de la nueva nación pero al mismo tiempo se constituyeron en un símbolo de la misma. Para el México independiente del siglo XIX, interesado en la formación de un país moderno, la heterogeneidad lingüistica y cultural fue un problema a resolver.

El nacionalismo revolucionario del siglo XX conjugó la búsqueda de la conciencia nacional en las culturas indias, planteando al mismo tiempo la desaparición de las diferencias en nombre de la unidad de la nación y la modernidad. Se elaboró una ideologia de lo indio que construyó imágenes estereotipadas y románticas del paisaje y la vida indigena y que recreaba las raices del mestizaje mexicano; las culturas indias se integraron ideológicamente como un ingrediente básico del nacionalismo. No obstante, en la práctica se propugnaba la necesidad de su asimilación; se proponia la transformación del indio de forma que contribuyera al desarrollo capitalista del país. Es decir, mientras el pasado indio se reconstruyó y se magnificó a través de expresiones artísticas, muestras museográficas y obras académicas, las agencias oficiales indigenistas justificaban la necesidad de integrar a las poblaciones indigenas para conseguir por fin una unificación de la conciencia nacional bajo el sino del mestizo (Medina, 1986: 136-138).

Tanto la postura integracionista del Estado como las corrientes marxistas en pugna a partir de 1968 y en el curso de la década de setentas, coincidieron en proponer la necesidad de la integración de los indígenas a las filas de los obreros y campesinos. Si bien los antropólogos marxistas planteaban la urgencia de su incorporación en el movimiento proletario, el indigenismo oficial del nacionalismo revolucionario también abogaba por la inclusión de los indios dentro del esquema clasista, descartando de hecho cualquier modelo de coexistencia cultural.

Durante las dos últimas décadas del siglo $\mathrm{XX}$, tanto las esferas academicas como los propios intelectuales indios han impulsado una revaloración de la diversidad cultural, de las identidades étnicas y de las solidaridades grupales. En los últimos años, se percibe con claridad un manejo de la conciencia étnica como estrategia de acción política. Se advierte que la lucha de los pueblos indios se apoya en la afirmación de las identidades étnicas, de modo que lo que fuera un estigma desde tiempos de la Colonia se abandera hoy como vehiculo de participación social y política. La diferenciación étnica en los procesos sociales contemporáneos se conduce como motivo de lucha, en el que la tradición se asocia con la modernidad y los deseos de progreso económico: modernidad y tradición dejan de oponerse para trascender las limitaciones de la communitas y negociar la participación en la societas. En este contexto, ha sido desplazada la intervención de los partidos políticos como representantes y voceros de los intereses de las poblaciones indigenas.

Entre los nahuas de la sierra de Zongolica se ha manifestado una 
alienación entre el deseo de acceder a una participación igualitaria dentro de la sociedad mayor y el de preservar la diferencia; no obstante, en los últimos años la afirmación de la etnicidad se esgrime como una forma alternativa de insertarse en la formación nacional. Aún cuando los nahuas se han movilizado desde hace más de dos siglos como jornaleros migrantes hacia las plantaciones de las tierras cálidas, las comunicaciones mediáticas y las facilidades para el traslado dentro y fuera de la región han repercutido de manera radical en la incorporación de elementos interculturales, configurando repertorios de hábitos y pensamientos, que hacen posible su desempeño en roles diversos y en distintos contextos (Garcia Canclini, 1999: 61, 185.). Por otra parte, aparecen aspectos compartidos con la cultura hegemónica, al mismo tiempo que se mantienen diferencias, es decir, la diversidad se manifiesta a través de una selección estratégica de tradiciones y costumbres.

Este proceso evidencia que las identidades son concepciones construidas y manipuladas, antes que esencias inmutables (Florescano, 1997: 123); resultan de un proceso social en el que surgen y se desarrollan en la interacción cotidiana con los otros (Giménez, 1998: 14). De ahi que, como señala García Canclini (ibid.), nuestro futuro como antropólogos trasciende hoy el estudio de las culturas locales, estables y tradicionales para llegar a examinar la interculturalidad y las tensiones entre lo local y lo global.

Hoy en día los nahuas de la sierra de Zongolica se movilizan por circuitos de mayor amplitud, llegando incluso -aún en casos aislados- a atravesar las fronteras del pais para integrarse a las corrientes migratorias hacia Estados Unidos. Estas transformaciones han dado lugar a una simplificación de las jerarquias de relaciones entre las localidades de la sierra que se habian mantenido entrelazadas en relaciones de comercio y de circulación de bienes materiales y simbólicos y al decremento de la importancia de la organización regional de tianguis y mercados. En el mercadeo semanal, los habitantes de los pueblos han mantenido relaciones horizontales de intercambio de productos artesanales, del huerto o de la milpa, prescindiendo en cierta medida de la disponibilidad de dinero para adquirir productos que no se encuentran en su entorno ecológico más inmediato. Estas dinámicas interregionales tienden a ser desplazadas por relaciones mercantiles establecidas a través de los circuitos comerciales más amplios, lo cual incide en una modificación de patrones y hábitos de consumo e incrementa la necesidad de disponibilidad de dinero en efectivo. Durante las últimas dos décadas, el desarrollo de los pueblos de la parte alta de la sierra, se habia sustentado mediante la venta de madera, muebles y carbón, sin embargo los recursos forestales se encuentran en vias de un paulatino agotamiento. Por otra parte, la carencia de tierras de cultivo y su bajo rendimiento, obliga a determinados sectores de la población a su incorporación en actividades de diversa indole en la búsqueda de recursos alternativos, diversificándose con ello los patrones de migración y las actividades al interior de las mismas localidades. 
La relación entre los pueblos de la sierra y las instancias del Estado ha sufrido también transformaciones notables. Durante los gobiernos de Luis Echeverria (1970-1976) y López Portillo (1976-1982), se modificó el discurso indigenista que hablaba de integración para dar paso a la idea de la importancia de la pluralidad y la diversidad cultural. Se fortalecieron entonces las instituciones orientadas a la educación bilingüe bicultural, al fomento a las culturas populares y a la formación de la clase magisterial en las regiones indigenas, sector que ganaria espacios en las contiendas políticas de las localidades. Se postula el "indigenismo de participación", según el cual los pueblos indios debian ser sujetos de su propio desarrollo, y se pone en marcha el programa COPLAMAR (Coordinación General del Plan Nacional de Zonas Deprimidas y Grupos Marginados), a través del cual se pretendia abatir los indices de marginalidad. Si bien esta politica fue objeto de criticas relativas al excesivo burocratismo y al manejo clientelar por parte del partido oficial, se presentó la tendencia hacia el aseguramiento de los minimos de bienestar a las poblaciones marginadas (Oehmichen, s/f: 6).

Durante el gobierno de Miguel de la Madrid (1982-1988), se inicia la transición hacia el neoliberalismo y se promueve la idea de que es necesario poner fin al paternalismo del estado hacia las poblaciones indigenas. Seria sin embargo hasta la administración salinista cuando se implementa de forma radical el liberalismo social, postura que se respaldaba en un supuesto respeto a la pluralidad, la libre participación y el apoyo a las iniciativas de la población través del PRONASOL (Programa Nacional de Solidaridad). Bajo la idea de que los pueblos indios deben ser sujetos de su propio desarrollo y que es necesario suprimir la tutela del estado, el salinismo estableció una clara distancia con el compromiso hacia el desarrollo económico y social de las regiones indígenas.

A través del Instituto Nacional Indigenista se persigue la consolidación de procesos organizativos, como el vehículo privilegiado para la canalización de los recursos de los Fondos Regionales de Solidaridad a los productores organizados. En el ámbito juridico se reformaban los articulos $4^{\circ}$ constitucional - que declara el respeto a las lenguas, usos, costumbres y tradiciones indigenas- y el 27 , que pone fin al reparto agrario. Mediante los Fondos Regionales de Solidaridad se apoya a las organizaciones indigenas que habian dejado de ser sujetos de crédito, después de la privatización de la banca y la desaparición de un gran número de empresas estatales (Oeminchen, op. cit.: 12).

En la normatividad para el manejo de los Fondos Regionales de Solidaridad, se establecia que las organizaciones serian las encargadas de administrar los recursos y decidir sus prioridades, con la salvedad de que los proyectos debian ser productivos, rentables y autosostenibles. Los Centros Coordinadores Indigenistas actuaron con cierto margen de autonomía para canalizar los Fondos y fortalecer a las organizaciones 0 grupos locales, siempre que éstos se ajustaran a una normatividad rigida 
en cuanto al tipo de proyectos a financiar, figuras asociativas y mencanismos de toma de decisiones. De este modo, se dejaba a un lado a quienes se encontraban imposibilitados para presentar proyectos productivos por carecer de tierras $u$ otros recursos, elementos indispensables según el esquema de solicitud para acceder a los beneficios del Programa (ibid.). Se favoreció a las comunidades y organizaciones más desarrolladas y con mayor experiencia, concentrándose los recursos en determinadas regiones del pais (Bello, 1996: 66).

Durante este periodo, la política indigenista se dirigió hacia la capacitación de los indígenas en el manejo de la eficiencia productiva y del mercado, pero sin una planeación coherente para el desarrollo de las regiones, y sin la vinculación con propuestas emanadas de las propias comunidades, ni con planteamientos de carácter étnico o cultural. Este esquema de organización se acompañó de un discurso que cuestionaba las políticas indigenistas anteriores, de orientación paternalista y asistencial, para proponer que los pueblos indios tienen la capacidad para organizarse en el manejo de los recursos asignados por el estado, priorizar sus necesidades y planificar su desarrollo. Ello daría lugar a que determinados sectores de las regiones indigenas exigieran su reconocimiento real como instancias de decisión, así como transparencia en la asignación de recursos. Las organizaciones indígenas y los representantes de los pueblos reclamaban ser reconocidos como sujetos sociales, interlocutores del estado (Oeminchen, op. cit.: 15-16).

En julio de 1990 se constituyó formalmente en la sierra de Zongolica el Fondo Regional de Solidaridad, integrado por unas cuantas organizaciones dirigidas hacia el acopio y comercialización de café, el aprovechamiento y fomento forestal, la apicultura, la acuacultura, el autotransporte y la producción agropecuaria. Sin embargo, los alcances de este Programa no se expresaron en resultados significativos, debido a la escasa presencia de organizaciones productivas en la sierra y al manejo de esquemas ajenos a la economía regional. Por otra parte, no se realizó trabajo de base en las comunidades ya que se priorizaba la relación con los representantes y no con sus habitantes (Bello, op.cit.: 104). En este periodo, las acciones del Centro Coordinador Indigenista de Zongolica estuvieron dirigidas a canalizar los recursos del Fondo Regional y a impulsar las organizaciones productivas consolidadas o en vias de hacerlo. El impacto generado no fue significativo, debido a las condiciones adversas para la implementación del tipo de proyectos apoyados por el PRONASOL: escasa vocación agrícola, alta siniestralidad, atomización de la tenencia de la tierra, movilidad constante de la población hacia fuera de la región, etc. Las comunidades de la zona fria de la sierra fueron prácticamente excluidas de la asignación de recursos de los Fondos Regionales (Hernández, 1999: 206).

En este lapso, en la sierra de Zongolica se aprecia un cambio drástico en cuanto a las formas de interpelar a los agentes del estado, a los grupos de 
poder e incluso a las propias autoridades de los pueblos. Se registran acontecimientos en que los encargados de dar seguimiento a los programas del INI, de vigilar el cumplimiento de las normas para la explotación forestal, o de gestionar la aplicación de recursos en obras de infraestructura, son cuestionados, agredidos de manera fisica o verbal y obligados a esclarecer el manejos de los recursos asignados a las comunidades. La población responde con energia y desconfianza ante las instancias gubernamentales y exige a éstas y a sus mismas autoridades, cuentas claras, eficiencia y una participación más democrática en la toma de decisiones.

Durante el sexenio del presidente Zedillo se replantearian las formas de canalizar los recursos, reformulando el funcionamiento de los Fondos Regionales y centralizando su administración con el fin de desactivar la movilización creciente de las organizaciones indigenas. El estado propone encauzar el apoyo a las poblaciones indigenas marginadas a través de los municipios, integrando nuevas instancias que supuestamente redundarian en una mejor planeación y canalización de los Fondos, Los Consejos Municipales. Se fortaleció a las autoridades municipales en el manejo discrecional de los recursos, abandonando la promoción participativa de la población y desactivando a las organizaciones como interlocutores del estado en el planteamiento de sus demandas y la opinión acerca de sus prioridades (Oeminchen, op.cit.: 17).

En la sierra de Zongolica, se dirigió la atención hacia las localidades de la zona fria, las cuales habian quedado excluidas de los programas impulsados por el INI durante el sexenio anterior, aún cuando era ahí donde se presentaban -como hasta ahora- los más altos indices de marginalidad y pobreza. Se otorgaron apoyos para la reactivación de la producción agrícola, la apertura y revestimiento de caminos y la comercialización de café $\mathrm{y}$ productos forestales. Al mismo tiempo, se fomentó la formación de grupos representativos de la cultura y tradición indigena a través de la Radio Indigenista, organizando regularmente encuentros de danzas tradicionales, de médicos y parteras, de grupos de artesanos, de compositores y escritores en lengua náhuatl, etc. De este modo se reforzaba el discurso oficial que reconoce la formación pluricultural de la nación mexicana.

En la sierra de Zongolica, la relación entre el Instituto Nacional Indigenista y las localidades se realiza a través de grupos organizados que se han establecido como sus interlocutores, y responden regularmente a las convocatorias para la asistencia a eventos oficiales, la participación en concursos o encuentros de arte popular, de medicina tradicional o de narrativa, la recepción de créditos y programas asistenciales y la elaboración de proyectos. Esta dinámica se ha establecido como una forma de legitimar y conducir las acciones de las instancias indigenistas. En términos generales, se percibe que el papel de las instituciones encargadas de la politica indigenista se reduce a una relación con grupos clientelares, organizados para la recepción de los programas, y no incide 
de forma significativa en la calidad de vida de la población de la sierra.

En la arena politica se aprecian transformaciones más profundas. Si bien las acciones indigenistas no siempre rindieron los frutos esperados tanto por sus promotores como por su receptores, unificaban distintas esferas de las región y se establecia de ese modo cierta forma de control partidario. El dominio ejercido por el estado a través del sistema unipartidista se ha visto menguado por la incorporación de un lenguaje político que reclama intervención en la toma de decisiones, y que en muchos casos prescinde de la mediación de los partidos politicos. En este proceso, las élites indigenas se han apropiado del discurso nacionalista, reivindicando al mismo tiempo los origenes. Se interesan, por ejemplo, en la escritura de la lengua náhuatl, en la escenificación de rituales apegados a la tradición como la boda indígena, o la petición de lluvias, aunque en su desempeño personal se hayan incorporado patrones culturales ajenos, como la transmisión del castellano a sus hijos como primera lengua.

Se trata, en sintesis, de una elaboración ideológica de lo étnico por parte de los sectores más instruidos, empleada para llevar a cabo la interlocución con el estado. La población de la sierra de Zongolica asume las representaciones que ha recibido de la sociedad mexicana al conferirles el estatus de grupo étnico marginado. Esta interiorización los provee de valores en el enfrentamiento con la sociedad dominante, afirmando su identidad étnica y persiguiendo su dignificación. Como señala Cardoso de Oliveira (1992: 39), el ejercicio de la identidad étnica debe interpretarse como un esfuerzo del individuo y del grupo para lograr su sobrevivencia social.

\section{El sistema de cargos en la dinámica local contemporánea.}

Como he mencionado en el curso de este trabajo, en México, una de las respuestas adaptativas de la población colonizada, fue la fuerte institucionalización de modelos de autogestión laica para el ejercicio de la religiosidad (Báez, 1998). Es por ello que se han interpretado estas formas como estrategias de resistencia ante el dominio colonial y como soluciones para estrechar la solidaridad étnica. Desde el punto de vista desarrollado a lo largo de las páginas precedentes, su importancia también radica en su capacidad para reproducirse en condiciones de asimetria y para resistir a transformaciones más radicales. La religiosidad de los nahuas, institucionalizada en torno a las imágenes de los santos, forma parte de las representaciones socialmente construidas y compartidas en el contexto de la asimetria social y cultural. Sin embargo, he tratado de enfatizar también que la tradición que refrenda y transmite el ritual está sujeta a procesos de diferente indole, en continua reinvención y reinterpretación.

En el curso de este trabajo he presentado una descripción etnográfica de la ritualidad festiva y prácticas ceremoniales de los nahuas de Atlahuilco. 
Ha sido mi intención plasmar la complejidad de un ámbito social donde los tiempos se entreveran y coexisten, entretejiendo fundamentos relacionados tanto con un sustrato prehispánico como con las redes globales del mundo moderno. De modo que elementos radicalmente opuestos conforman una imagen única que trasciende y afirma la realidad de forma continua. En esta afirmación se amalgaman tanto la invención de nuevas tradiciones como el interés en la perpetuación y la recurrencia al pasado.

Hemos visto que esta complejidad dificulta la interpretación del sistema de cargos contemporáneo desde las perspectivas que privilegian una posición en cuanto a sus atribuciones y funciones. En este sentido, las funciones niveladoras o redistributivas del sistema que se plantearon en los primeros estudios acerca de esta institución resultan inoperantes en un momentos en que se manifiesta en la región una creciente diferenciación social asociada a nuevas vias de obtención de prestigio y movilidad. De manera que resulta pertinente la observación sugerida por Greenberg (1981: 175) en cuanto a que los modelos de nivelación y estratificación pueden representar más bien, distintas etapas de la integración y dependencia de las comunidades con respecto al mercado.

Las localidades nahuas de hoy son "arenas culturales" en las que se enfrentan relaciones cambiantes, fundadas en intereses personales y colectivos de diferente indole. Los patrocinadores de las fiestas representan uno de los diversos grupos que compiten por el poder en el ámbito local. Por otra parte, se ha resquebrajado la unidad comunitaria fincada en la aceptación común hacia los rituales públicos impuestos por el control partidario del gobierno, por el financiamiento colectivo de las fiestas religiosas siguiendo una jerarquia más o menos estricta. Las facciones locales se enfrentan entre si a través de la filiación a distintos partidos politicos y organizaciones independientes, convirtiéndose en actores sociales que participan como fuerzas en la definición de su propio rumbo. En esta definición intervienen las corrientes interculturales traidas por los trabajadores migrantes, las nuevas generaciones de jóvenes con educación escolarizada, las comunicaciones mediáticas y la legitimación de la tradición como una forma de reclamar una posición politica para el pueblo en relación al estado.

La comunidad no se ajusta pues a la idea de unidad corporativa, regulada por el sistema de cargos como estrategia defensiva hacia las intrusiones del exterior; hoy en dia sus habitantes son actores sociales en el seno de una sociedad globalizada en la cual es el mercado, y no el estado, el que define en gran medida su formación cultural como ciudadanos (Lomnitz, op cit.: 182-186). El papel del sistema de cargos en la vida de los nahuas sigue siendo relevante, pero ya no desde la discusión concerniente a sus efectos niveladores o de economia de prestigio, sino desde la perspectiva de la reactualización y refuncionalización del ritual y de la fiesta y de las nociones locales de poder y de simbolismo. 
Estas manifestaciones se inscriben en el curso de un proceso de desregionalización de la sierra de Zongolica como un espacio étnico claramente delimitado. Hoy en día se acortan velozmente los pasos del intermediarismo local entre los pueblos y rancherias que se relacionaban comercialmente con el exterior a través de los intermediarios de Tequila y Zongolica. Las cabeceras municipales y sus representantes, ganaron espacio político en los años ochentas, a partir de la transformación de las rutas de comunicación intrarregional y hacia el corredor industrial Córdoba-Orizaba. En este contexto se inscribe la movilización y articulación de simbolos, y la objetivación de nuevas agrupaciones y nuevas relaciones entre las microlocalidades.

La pluralidad religiosa se relaciona con la necesidad de independizarse del control central de la cabecera municipal y de lograr mayor autonomia en la toma de decisiones colectivas, dirigidas hacia el beneficio del propio grupo residencial y sin las mediaciones ejercidas por la comunidad de los cargueros. Este pluralismo ha servido como un catalizador de las inquietudes e intereses politicos de los segmentos territoriales; ha sido la via para proteger los intereses particulares, pero no sólo de los disidentes religiosos, sino también de quienes por su ubicación dentro de la misma microlocalidad comparten un campo de intereses comunes.

En la medida en que decrece la participación en los rituales públicos, se expresan disentimientos en las nociones colectivas del tiempo y del espacio sociales. Mientras que el culto a las imágenes de los santos implica un movimiento ritual a través del espacio asi sacralizado, los conversos se reúnen en casas de oración varias veces al dia, afirmando la importancia de la experiencia personal. La concepción del espacio local como un plano sacralizado a través del movimiento ritual de las imágenes de los santos, se transforma en una noción en la cual es la oración la que sacraliza al individuo (Grimes, 1981: 63).

La diversificación religiosa promueve nuevas vias para la obtención de movilidad social y de relaciones con sectores regionales y coloca a los disidentes al margen del sistema de intercambios, los cuales proporcionaban un sentido de pertenencia a la comunidad municipal. Desde mi punto de vista, esta diversificación proporciona mecanismos para la consolidación de esferas privadas, que de manera gradual disocian al individuo del ámbito colectivo demarcado por la rotación de los cargos religiosos. Este accede a formas de sociabilidad que le permiten privatizar determinados ámbitos de su existencia, distanciándose de las redes amplias y oponiéndose a las imposiciones colectivas de la costumbre (Castan et. al., 1992: 12).

No obstante, las "fiestas de renovación de la cabecera" expresan aún la afirmación de valores comunes entre la mayoria de la población de Atlahuilco, de modo que los intereses más locales de cada una de las microlocalidades no impiden las consideraciones acerca de los asuntos 
colectivos y la pertenencia al conjunto. Estas fiestas, distribuidas a lo largo del año y a lo ancho del municipio constituyen, en este sentido, un reflejo de las relaciones entre las agrupaciones residenciales. Los responsables de su realización, mediante el acopio de bienes de consumo, producto de las cooperaciones de los miembros de su grupo residencial y parental, ponen en circulación externa estos bienes que en su mayor parte proceden de la facción y los remiten a la disponibilidad del resto de la comunidad. A través del sistema descrito, se norman una serie de intercambios entre los hombres entre si y entre ellos y sus divinidades, generando un tipo de orden en la diversidad social. El sistema refiere tanto al dominio de las cosas intercambiables, como a alianzas entre grupos domésticos y agrupaciones residenciales, propiciando relaciones complejas de competencia y cooperación.

Las prácticas relativas al ciclo ceremonial basado en el festejo a las imágenes de santos que se localizan en el interior del templo y las capillas, han sido una via para demarcar la posición de los participantes en su entorno y en su relación con los otros. No obstante, he tratado de argumentar que actualmente en Atlahuilco se gesta un proceso de descentralización de la cabecera municipal como el centro de la organización sociorreligiosa. Mi análisis sugiere la existencia de dos tendencias opuestas en cuanto a la vitalidad y transformaciones del sistema de cargos: por una parte se expresa la continuidad de una estructura organizativa en la cual persisten gran parte de los rasgos señalados para el típico sistema de cargos mesoamericano. Por otro lado, se manifiestan posturas criticas hacia dicha institución provenientes de sectores católicos progresistas y otras agrupaciones religiosas como La Luz del Mundo. La mayoria de la población de Atlahuilco, pese a las diferencias, confluye en un entusiasta fervor hacia el santo patrono, y en la participación en las fiestas principales del calendario anual que aqui he llamado "fiestas de renovación del centro ceremonial".

Sin embargo, también he señalado que actualmente se gesta un proceso de abreviación de las intermediaciones entre los caserios y las instancias más amplias, evidencia de la movilidad creciente de los límites y de la transformación de las pautas de interacción entre las agrupaciones residenciales. Se expresa el imperativo de enfatizar la pertenencia a las microlocalidades, en la búsqueda de cierta autonomia a favor de la propia subdivision. Desde mi punto de vista, la organización religiosa constituye un epifenómeno de estos procesos y de las tensiones que generan; a través de las prácticas ceremoniales se manifiestan las disidencias o la conexión con el conjunto.

La complejización de la realidad social genera lo que Adams (1995: 161) llama "nuevos vehiculos de supervivencia politica". En este contexto, el sistema de cargos sufre una suerte de desplazamiento en su papel estratégico de organización y control grupal. El surgimiento de nuevas formas de expresión y de organización, sugiere que los nahuas realizan hoy en dia un ajuste de cuentas entre la tradición y los imperativos de la 
supervivencia, mediante la construcción de discursos que conjugan posiciones tradicionalistas, ideologias de progreso y orgullo étnico y ambiciones de desindianización. Mientras que las reivindicaciones étnicas son expresión de las clases cultivadas, los más pobres aspiran a salir de las condiciones de alienación en que los mantiene el estigma de ser culturalmente diferentes. En dicha dinámica, sin embargo, continúa vigente la reproducción de complejos culturales asociados a la tradición y pensamiento religioso mesoamericanos.

De modo que si bien una de las tendencias que se perfilan en Atlahuilco, como en otros pueblos de la sierra, se dirige hacia el reforzamiento de las identidades basadas el la adscripción residencial, el concepto de pertenencia al "pueblo" y la identificación con San Martín, su representante emblemático, continúan como las referencias grupales más importantes. Existe, en último término, una tensión entre estas vias de identificación y los procesos referentes a la descentralización de la cabecera municipal como el centro político-religioso, a la sustitución del sistema de cargos como el sistema regulador de las relaciones entre las distintas instancias territoriales, y al surgimiento de organizaciones locales heterogéneas.

El esfuerzo realizado hasta aqui ha sido quizás insuficiente para formular la complejidad de los procesos contemporáneos en un espacio interétnico en el que se expresan fracturas en las relaciones entre identidad étnica y organizaciones ceremoniales y coexistencia de formas diversas de identificación grupal. Se manifiestan contradicciones signadas por las desigualdades sociales, por la oposición de valores y de visiones del mundo, así como por la resistencia a la dominación política y económica. Ello implica la apropiación y reinterpretación de elementos de distinta naturaleza, el reencuentro con lo propio y la continuidad de un sustrato anclado en el pasado prehispánico. 


\section{APENDICE \\ SEMANA SANTA EN LA MONTAÑA. ETNOGRAFIA DE UNA FIESTA DE RENOVACION DEL CENTRO CEREMONIAL.}

El episodio ritual de Semana Santa en Atlahuilco culmina el Domingo de Pascua con una procesión en torno al circuito ceremonial cuyo punto de partida es el interior del templo, atravesando el atrio y rodeando la edificación de la iglesia y sus construcciones adyacentes en sentido inverso a las manecillas del reloj ${ }^{1}$. Los participantes en esta procesión son todos los mayordomos, sus comitivas, la totalidad de las imágenes de los santos que se localizan en el interior del templo, y el pueblo en general.

El final de esta procesión se sella con la desaparición de los judios o "jurios" de la escena ritual. Se realiza después una comida y bebida en el atrio de la iglesia financiada por los mayordomos y en la que participan habitantes de todos los puntos del municipio, algunos de los cuales sólo se hacen presentes en este espacio público en ocasión de las fiestas de renovación del centro ceremonial.

El ceremonial de Semana Santa, se encuentra inserto en el sistema general de celebraciones a las 42 imágenes que integran el calendario festivo anual. Son los mayordomos de cada una de las imágenes que protagonizan los distintos momentos de la pasión y muerte de Cristo, los fiscales, los tekitlahtomeh y los doce Apóstoles comandados por un Apóstol Mayor, los encargados de poner en marcha la celebración, la cual requiere de una elaborada organización que se desarrolla en dos escenarios: en la esfera doméstica de cada uno de los mayordomos involucrados y en el centro ceremonial de Atlahuilco. En la primera, se celebra el compromiso del mayordomo con su circulo de colaboradores y con la imagen solicitada, y en la segunda, se participa en la secuencia ritual que supone el episodio de la Semana Santa y que debe llevarse a efecto en el centro ceremonial, donde participa todo el pueblo. De manera que los mayordomos y sus comitivas, una vez cumplida la fase doméstica de la

\footnotetext{
Evon Vogt (1979) observó entre los zincantecos que éstos, al recorrer un circuito ceremonial, casi siempre lo hacen en sentido inverso al de las agujas del reloj, antigua costumbre maya. Este autor apunta que existen evidencias, por una parte, de que este modelo de circuito entre los mayas es anterior a la conquista, $y$ por la otra, de que las procesiones católicas del siglo XVI coincidian también con este modelo. Ello no es suficiente según su punto de vista, para explicar la significación de este evento ni su persistencia hasta ahora. Su interpretación se relaciona con el simbolismo de las manos derecha e izquierda para los zinacantecos. (p. 13-15)
} 
celebración a la imagen correspondiente -similar a la de cualquier otra imagenparticipan en el desarrollo del episodio público en el contexto de la Semana Santa.

Para los nahuas los dias de Cuaresma son de oscuridad; son dias de tinieblas en los que se suspenden las actividades rituales relacionadas con el ciclo de vida como los bautizos, peticiones de mujeres y casamientos. El final de ella, una vez transcurrida la fiesta de Pascua el Domingo de Resurrección, representa el "nuevo amanecer". En esta temporada, además de las fiestas relacionadas con la pasión y muerte de Jesucristo, se celebra la festividad de San José, considerada una de las nueve imágenes principales del santoral. Asi mismo, el mayordomo de San Juan Apóstol, reconocido como el más importante de los apóstoles, debe ofrecer una comida ritual el último viernes de la Cuaresma, simbolizando la relevancia del personaje dentro de la secuencia representada aunque en el episodio de la Semana Santa propiamente dicho, no juegue un papel muy relevante.

Dentro de la temporada de Cuaresma, también se desarrollan las secuencias encaminadas a la constitución del grupo de hombres que representarán a los doce apóstoles durante toda la Semana Mayor, a cargo del Apóstol Mayor, representante y organizador del grupo. Un elemento diacrítico significativo de este episodio lo constituye el tañido de una trompeta, instrumento utilizado únicamente durante la Cuaresma y que marca los momentos culminantes de toda la temporada, cada viernes de Cuaresma y más intensamente durante los dias de Semana Santa. La trompeta, las matracas, los cohetes de pólvora y el campanario demarcan sonoramente el tiempo sagrado y los momentos culminantes durante estos cuarenta días.

\section{El desarrollo del ceremonial de Semana Santa.}

Como he señalado, el episodio ritual de Semana Santa en el centro ceremonial de San Martín Atlahuilco, supone otras fases de celebración en los altares domésticos de los mayordomos encargados de las imágenes participantes:

San Ramos

Padre Jesús Nazareno

Señor Calvario

Santo Entierro

La Resurrección

Intervienen además otros funcionarios especiales de Semana Santa en cuyos hogares se desarrollan también las secuencias correspondientes a su investidura: 
-E1 Fiscal y el Teniente Mayor -encargados de apoyar en la instalación de enramadas para las estaciones del Via Crucis, de la mesa para la Ultima Cena del Jueves Santo y otras adecuaciones de este tipo a lo largo de la Semana.

-El Apóstol Mayor y los Doce Apóstoles.

-Dos tekitlahtomeh, responsables de preparar y servir los alimentos durante la Ultima Cena del Jueves Santo.

-El cornetero.

-El Presidente Eclesiástico o Lector quien coordina al conjunto de mayordomos y funcionarios especiales.

-El Sacristán Mayor y los doce Sacristanes Menores.

Las celebraciones de Semana Santa inician en el altar doméstico del mayordomo de San Ramos, la víspera del Domingo de Ramos. En el hogar del mayordomo que "entregará" la imagen, es decir, que finalizará su año de servicio a San Ramos, se sirve el penúltimo viernes de Cuaresma, la comida ceremonial de entrega del cargo. Esta comida representa el punto culminante de su gestión y es el acto más formal de entre todos los que se celebran en la esfera doméstica del ceremonial de la mayordomia. Se ofrece en la vispera de la entrega de la imagen en el templo y del ofrecimiento de la misa que expresa públicamente el final de la gestión del mayordomo.

Pero al mayordomo de San Ramos le corresponde ofrecer un día más de comida a sus teachkameh, su circulo de colaboradores. Ello se debe a que es necesario adornar palmas para la ceremonia pública previa a la misa del Domingo de Ramos, deshojar pétalos de rosas de castilla y preparar a cuatro niños que cantarán alabanzas a San Ramos durante la procesión, tocados con coronas de carrizo forradas de papel de china.

Durante la víspera pues, mujeres de Tepexititla, -congregación enclavada en la montaña, a dos horas de camino del centro ceremonial, y anfitriona por ahora de San Ramos-, recolectan flor de manzanilla y rosas de castilla en los jardines domésticos, para iniciar el arreglo de las palmas y coronas por la noche, a la llegada de los teachkameh. Asi mismo, preparan comida para recibirlos: atole de maiz agrio, café, arroz, frijoles, tortillas y xocotamales. Después de todo un dia de trabajo, al caer la noche, los teachkameh o colaboradores del mayordomo, trasponen el umbral de la habitación de madera donde descansa, 
sobre el altar, la figura de San Ramos: algunas parejas, algunos hombres solos y los cuatro niños que al dia siguiente dedicarán alabanzas y flores deshojadas a la figura de Jesús montado en un asno.

La reunión es explícitamente para adornar palmas y coronas para los niños, asi que en la penumbra y con mesura, los recién llegados se van colocando en los tablones instalados alrededor del Santohkalli a manera de asiento. Iluminan el recinto las suaves flamas de las veladoras colocadas en el altar dedicado a San Ramos y a sus acompañantes, tres imágenes más, solicitadas previamente a sus mayordomos para que estén presentes en esta fase del ceremonial.

Después de comer, los asistentes se dedican, casi en silencio, a adornar palmas, deshojar rosas y elaborar las coronas de los niños cantores. Terminada la tarea comienza el baile. Tres jóvenes músicos procedentes de Tikonka, rancheria vecina, se instalan en una esquina del salón, al lado derecho del altar, y tocan sones tradicionales y otras melodias al ritmo de las cuerdas del violin, la guitarra y el guitarrón. Los asistentes bailan en el estrecho espacio del Santohkalli, de piso de tierra apisonada y en la suave penumbra que despiden las velas. Hacia la medianoche, todos se retiran a descansar para salir muy temprano, al dia siguiente, rumbo a Teopantitla (de teopantli, templo) como denominan al centro ceremonial, donde se realizará la celebración del Domingo de Ramos, en la que San Ramos es el principal protagonista.

i) Domingo de Ramos.

Las mujeres del grupo doméstico del mayordomo de San Ramos no asisten a la misa. Parte de la comitiva acompaña a la imagen rumbo a la iglesia, con los demás teachkameh, mientras que algunas mujeres permanecen preparando las canastas con comida para ofrecer al resto de los mayordomos que no asistieron al banquete en el espacio doméstico. Una vez todo listo, esperarán en el atrio, sentadas en el suelo, en torno a sus canastas hasta que finalicen las procesiones y la misa para ofrecer tortillas, frijoles, aguardiente y cerveza a todos los mayordomos que cumplen su gestión en el calendario ceremonial actual, como se prescribe en el ceremonial de entrega del cargo.

En Teopantitla, el amanecer de este dia de primavera fue anunciado por un repique de campanas y el sonido de la trompeta ceremonial de Semana Santa. Un hombre de prestigio, mayordomo varias veces y presidente municipal en alguna ocasión, sube a la torre de la iglesia, y mirando hacia los cuatro puntos cardinales, entona algunos compases para anunciar que comienza la Semana Santa. En tanto se acerca la hora de la celebración litúrgica, que dará inicio antes del mediodia, los mayordomos de las imágenes que están dentro del 
templo, llegan a cambiar las vestiduras de los santos, las flores y manteles de los nichos y repisas donde se encuentran colocadas. A las siete treinta de la mañana, el mayordomo de la Virgen de la Luz, acompañado por una pequeña comitiva, llega procedente de Tikonka para cambiar la indumentaria de la imagen. Pretende que luzca decorosamente arreglada durante estos dias en que se intensificará la actividad dentro del templo. Realizan la tarea con sumo cuidado, hablan en susurros y son los dos hombres mayores los encargados de quitar las prendas anteriores y colocar las nuevas. Llama mi atención verlos realizar esta tarea con extrema delicadeza: prenden el velo con alfileres, cuidando de que los pliegues del manto estén bien arreglados, colocan los tocados a los dos angelitos, cuyo busto reposa a los pies de la Virgen, (a quienes aparentemente asocian con niños lactantes puesto que les colocan una prenda propia de éstos: un gorrito de satín, color rosa mexicano, con pliegues, encajes y moños, sustituye al que tenian antes, color naranja). Una vez concluido el cambio de indumentaria, de manteles, de cirios y de las flores del jarrón, se retiran del templo.

Mientras tanto, han ido llegando otros hombres sucesivamente. Se acercan con prisa al altar mayor a saludar a los santos patronos (a San Martín Obispo y San Martín Caballero), a la virgen de Guadalupe en el altar de la izquierda, y a las imágenes colocadas en el altar de la derecha. Vienen con camisas limpias aunque muy desgastadas y después del saludo se dirigen a la sacristia, a preparase para iniciar el cambio de indumentaria, de manteles, de flores y de cirios, a las imágenes a su cargo. En este movimiento se hace evidente que los hombres -más que las mujeres- se adueñan de la sacristia y los altares. Se mueven dentro de este espacio ritual exclusivamente masculino, con suma familiaridad, haciendo patente su pertenencia a la comunidad de mayordomos.

Se las ingenian para arreglar con cuidado las repisas, nichos y jarrones. Se sustituyen las flores marchitas y las velas y veladoras consumidas. Los ramos de flores son sencillos: un manojo de nube, algunas gladiolas, tres o cuatro azucenas y dos o tres claveles rojos. Proveer a la imagen de flores frescas y cirios nuevos semanalmente durante su año de servicio, es parte del gasto que corresponde sufragar a cada mayordomo.

Así se inicia el día del Domingo de Ramos, que hasta aqui no ha sido muy distinto a cualquier otro domingo, excepto por el tañido de la trompeta que despertó a los que no madrugan antes del amanecer. Cerca del mediodia la gente comienza a acercarse al atrio del templo y la Capilla del Señor Calvario, llevando palmas adornadas con ramitos de flor de manzanilla y rosas de castilla. Llegan de distintos puntos del municipio, y se aprecia el esmerado arreglo de hombres y mujeres. Fuera de la capilla se ha colocado una enramada donde descansa la 
imagen grande de San Ramos (que generalmente se encuentra dentro del templo), esperando la hora en que encabezará la procesión, una vez bendecidas las palmas. La gente espera, y pese a lo intenso del sol, permanece impasible durante una hora en tanto llega el sacerdote procedente de Tequila. Los discretos acordes de un violin acompañan la danza de ocho Tocotines de 9 o 10 años y una pequeña Malinche vestida de blanco, que apenas llegará a los seis. Bailan bajo el sol durante algunos minutos. Nadie habla en voz alta, todo se expresa con mesura y recato, como si permeara una actitud de no mostrar demasiado interés por lo que está pasando, pero si profundo respeto.

El sector de población mestiza parece haberse asimilado a este patrón de conducta; es evidente el esmero y la prisa por llegar a esta reunión casi silenciosa y aparentemente indiferente, con sus palmas previamente adquiridas y adornadas para este momento. En esta espera destacan las mujeres, son quienes han traido sus palmas. Los hombres se encuentran dispersos, deambulando por los tendajones o recargados en las bardas del atrio. El arribo del sacerdote se anuncia con un repique de campanas y los acordes de la trompeta hacia los cuatro vientos desde la torre del templo.

Se acerca el sacerdote y comienza la bendición de las palmas en un espacio ritual exclusivo de la Semana Santa: la capilla del Señor Calvario y su atrio, cuyos límites no están demarcados visualmente sino tácitamente. El sacerdote bendice las palmas mientras un viento suave mitiga los estragos del sol. Después de la bendición de las palmas, el sacerdote y el Sacristán Mayor encabezan la procesión, seguidos por San Ramos, su comitiva y el resto de la gente llevando las palmas bendecidas.

La procesión rodea el templo principal y el atrio. En las cuatro esquinas de la manzana se han colocado enramadas de axocopa -helecho silvestre que abunda en la región-, sobre una plataforma de madera de unos dos metros de superficie y cuatro metros de altitud. Se suben a cada una de éstas los cuatro niños procedentes de Tepexititla invitados por el mayordomo de San Ramos, vestidos de blanco y con canastas de pétalos de rosas de castilla, esperando el paso de San Ramos. Una vez que éste llega al pie de cada enramada la procesión se detiene, los niños cantan alabanzas y avientan pétalos de flores a la imagen durante breves segundos. Luego la procesión continúa en dirección opuesta a las manecillas del reloj. Al llegar al siguiente punto del cuadrado imaginario que rodea la iglesia, se repite el acto de los pétalos de rosas. La comitiva del santo ha preparado todo este acto y deben llevar una escalera de esquina en esquina para que los niños puedan bajar y subir a la plataforma. Los niños llevan colocada en la cabeza una corona de carrizo, preparada el dia anterior en la casa del mayordomo, forrada de papel de china de distintos colores y rematada con una 
crucecita en la cúspide de la corona que simula una pequeña cúpula.

Terminado el recorrido la procesión se introduce en el templo y comienza la misa. Es larga y no hay espacio para sentarse, pero la concurrencia es paciente, escucha en silencio y casi sin moverse la larga homilia. Un coro de jóvenes acompañados por los acordes de una guitarra, ameniza un poco la gravedad del momento. La celebración litúrgica llega al final y se inicia una nueva procesión, tal y como sucede siempre que la misa fue dedicada a algún santo en particular. Nuevamente repican las campanas mientras en el atrio de la iglesia esperan Los Tocotines. Al frente marcha la Cruz Alta, después el sacerdote con el incensario, la comitiva de San Ramos y por último los Trece Apóstoles, quienes han aparecido en escena para iniciar una participación que resultará destacada a lo largo de toda la Semana Santa. Al concluir la procesión, y después de dejar a la imagen en su lugar correspondiente al interior del templo, la gente se dispersa por el atrio y sus alrededores. En el hogar del nuevo mayordomo de San Ramos se inicia el ceremonial correspondiente a la fase de recibimiento del cargo, la cual se desarrollará a lo largo de siete dias.

La gente de las rancherias y de los parajes cercanos a la cabecera permanece en el atrio una vez terminada la ceremonia. El mayordomo saliente y su comitiva oferecen los alimentos traidos desde su hogar para el resto de los mayordomos. El resto de gente se distribuye en grupos en torno al templo; grupos de mujeres conversan sentadas en el suelo, y los hombres departen entre si bebiendo cerveza y aguardiente durante el resto de la tarde.

Quienes reciben hoy la mayordomia de San Ramos, se han preparado desde dias atrás para el ceremonial de recibimiento. En su cocina se encuentran listas las viandas, y las molenderas preparan tortillas y café, esperando a la comitiva del nuevo mayordomo que llegará con la imagen, para colocarla en el Santohkalli que será su morada durante un año. Esto sucede por la tarde, una vez que hubo concluido la fase pública de la fiesta de San Ramos y el tiempo dedicado a la convivencia social en el atrio. En otro punto del pueblo, las ollas y cazuelas se encuentran humeantes también, iniciando la fase de entrega de la imagen de La Resurrección, la cual concluirá el Domingo de Pascua.

De lunes a miércoles de la Semana Santa no se lleva a cabo ningún evento en el centro ceremonial, sin embargo, en distintos puntos del municipio se preparan las celebraciones de los dias subsiguientes. En Atlehuaya -la congregación más alejada de la cabecera- en el hogar del Tekitlahto, se preparan los platillos que se llevarán al centro ceremonial para realizar la representación de La Ultima Cena el Jueves Santo. El sábado se realizará el banquete de entrega del cargo en la casa del mayordomo de La Resurrección y el Domingo de Pascua se iniciará el 
recibimiento de esta última imagen en la casa del mayordomo entrante. Así mismo, el nuevo mayordomo de San Ramos culminará la fase de recibimiento de su imagen el mismo sábado o domingo.

De modo que en distintos hogares del espacio municipal de Atlahuilco se preparan alimentos, se entrelazan margaritas para formar collares de flores y se brinda con aguardiente y cerveza. En las cocinas se mantiene vivo el fuego meintras los hombres acarrean leña, agua, cajas de cerveza y destazan al animal o animales sacrificados si se trata de una fiesta de entrega del cargo. Todo ocurre en la intimidad de las cocinas y aunque participan un número limitado de personas, los cohetes de pólvora, emitidos constantemente, tienen la función de hacer explicito al resto de la comunidad que en dichos puntos especificos se lleva a cabo el desarrollo de un ceremonial que todos conocen.

ii) Jueves Santo: Lavatorio y Ultima Cena.

A las seis de la mañana la trompeta, tocada hacia los cuatro puntos cardinales desde el campanario del templo, anuncia el inicio de este dia de fiesta entre el repique de campanas. Volverá a ser escuchada a las nueve, después a las doce y por último a las seis de la tarde. A partir del mediodia se instalan alrededor del atrio algunos tendajones movibles que ofrecen golosinas y algo de comida y bebida. A las seis de la tarde, el mismo sonido de la trompeta anuncia que es hora de comenzar la celebracion. El interior del templo se ve solemne en su sencillez, los dos santos patronos del pueblo, quienes generalmente ocupan el sitio principal en el altar, ahora fueron sustituidos por el Santísimo. El altar está adornado con especial austeridad, sólo con cirios y ramos de flores blancas. Los Trece Apóstoles se encuentran sentados en dos filas, frente a frente, dejando libre el pasillo. Transcurre la misa que inicia con unas cuantas decenas de mujeres, poco a poco se acercan más personas.

La mayoria de los asistentes son pobladores de la cabecera. Se nota la ausencia de gente de las localidades de la montaña; ello se debe a que la celebración concluirá por la noche, lo que dificulta el retorno, y a que al dia siguiente, el Viernes Santo, estarán presentes para el Vía Crucis y la Crucifixión que se realizarán durante el dia.

Durante el sermón, el Tekitlahto y dos hombres de su comitiva inician movimientos para instalar en la entrada del templo la mesa para la representación de la Ultima Cena. El sacerdote se impacienta y les ordena suspender la tarea, porque ahora mismo intenta transmitir la idea de que el lavatorio de pies que realizó Jesús a los apóstoles representa un acto de profunda humildad, cuyas enseñanzas debemos incorporar a nuestras vidas. 
Tiene que insistir varias veces para que lo escuchen puesto que al parecer, para el Tequitlahto y su comitiva es más importante preparar la mesa que participar de la celebración litúrgica.

Llegado el momento de El Lavatorio, el cual parece causar expectación entre los asistentes, Los Apóstoles, ataviados con túnicas y una banda cruzada en el pecho con el nombre del personaje a quien representan, se despojan de su calzado y dejan que el sacerdote y algunas mujeres laven sus pies, en representación del episodio relatado en el Evangelio, en el cual Jesús hizo lo mismo a sus discipulos.

Al final de la misa es posible por fin instalar la mesa para la representación de la Ultima Cena. La comitiva del Tekitlahto acerca la imagen de Padre Jesús Nazareno (de dimensiones aproximadas a las de una persona). Esta imagen lleva una cruz sobre sus hombros; se le despoja de ella para colocarle un pan en las manos con forma de pez, sostenido por dos cordones, y se le ubica en una de las cabeceras de la mesa donde se servirá la cena para los Trece Apóstoles. Estos, mientras tanto, se encaminan a la capilla del Señor Calvario para colocarse una sobretúnica que da mayor formalidad a su atuendo.

El Tekitlahto, cuya responsabilidad es la de financiar y servir la cena para los Apóstoles y Padre Jesús Nazareno, se situó a las puertas del templo horas antes de la celebración de la misa. Llegó desde Atlehuaya acompañado de cinco o seis personas que lo ayudaron a colocar la mesa y a servir los platillos que trajeron preparados desde su cocina: chicharos, pescado seco, frijoles, pan, tortillas y atole de maiz quemado. La cena es extremadamente frugal y se desarrolla casi en silencio; han colocado presidiendo la cabecera norte de la mesa, a la imagen de Padre Jesús Nazareno, la cual acompaña en el acto de comer sosteniendo en sus manos el pan en forma de pez. Se brinda con una botella de vino dulce de jerez que escancia uno de los Apóstoles. (La sencillez de los platillos contrasta con los que fueron servidos durante la misma celebración en Tequila, municipio vecino donde existe mayor circulación de dinero: canastas de fruta, tazones de chocolate y atole, habas, tempequistles y generosas porciones de pescado).

Al final de la cena, se ofrece informalmente a algunos de los asistentes el resto de los contenidos de los recipientes y canastas que descansan sobre el piso, en torno a las mujeres de Atlehuaya. Los Apóstoles se dirigen a la capilla del Señor Calvario a despojarse de las túnicas y se preparan para velar durante toda la noche a la imagen del Santísimo que permanecerá expuesta en el altar principal del templo. Se rezan rosarios hasta la medianoche, y los viajeros de Atlehuaya descansan en un pequeño recinto, junto a la capilla del Calvario, que sirve como posada para los viajeros durante las fiestas de renovación del centro ceremonial. 
iii) Viernes Santo.

A las diez treinta de la mañana se inicia el Vía-Crucis alrededor del la manzana de la iglesia, donde se han colocado pequeñas enramadas que representan las estaciones de las caidas de Jesús. Se nota la presencia de habitantes de todos los puntos del municipio. Algunos hombres se turnan para cargar durante tramos cortos una cruz de madera de unos diez metros de longitud. En cada estación, antes de iniciar el rezo, se escucha el sonido de la trompeta y las matracas de madera. Los Apóstoles van custodiando la cruz, llevan un cirio encendido adornado con flores; lucen agotados puesto que han permanecido en vigilia y en ayuno desde la Ultima Cena. La procesión parte de la capilla del Señor Calvario; la Primera Estación está instalada justo frente a la entrada principal del atrio. A partir de ahí avanzará en sentido opuesto a las manecillas del reloj hasta rodear la iglesia, deteniéndose y orando en cada una de las doce estaciones.

Poco a poco se agrega más gente a la procesión. Las mujeres aparecen ataviadas con la indumentaria local completa, de gala; muchachas de Acultzinapa, la localidad más lejana del centro ceremonial, se distinguen por su atuendo: han sustituido el traje de lío y blusa de encaje por faldas y blusas de corte urbano, decoloran su cabello con agua oxigenada y lo adornan con pasadores brillantes. Percibiendo detalles de la indumentaria de las mujeres es posible reconocer su lugar especifico de procedencia: el tipo de faja, los, colores de la blusa y en general, el atuendo y los movimientos corporales. No todos los recién llegados se incorporan a la procesión. Parte de los asistentes esperan en el atrio, instalándose por grupos de vecindad y apropiándose de ese espacio mientras inicia la celebración al interior de la iglesia.

Al concluir la representación del Vía Crucis se introduce la procesión en el templo antecedida por la cruz de madera que un hombre lleva a cuestas, y comienza uno de los episodios más intensos de la Semana Santa. Los Apóstoles se dirigen a la capilla del Señor Calvario y sacan de ahi la figura de Santo Entierro, la cual reposa horizontalmente dentro de un ataúd con tapa de vidrio, precedidos por el Sacristán Mayor y uno de los Sacristanes Menores (quienes llevan la cruz alta y el incensario), los matraqueros y el cornetero. Colocan a la imagen de Santo Entierro -dentro de su ataúd- frente al altar mayor del templo, y entre varios hombres se hace lo posible por sostener de pie a la cruz e iniciar la representación de La Crucifixión. De la capilla del Señor Calvario parte una nueva procesión en la que hacen su aparición los "jurios". Vienen cuatro "jurios chicos", protagonizados por cuatro niños y ocho "jurios grandes", caracterizados por hombres adultos. Están vestidos con túnicas negras. Los niños llevan en sus 
manos charolas con los objetos que serán utilizados en la Crucifixión: los clavos, la corona de espinas, la peluca y el atuendo que convertirá a Santo Entierro en el Cristo crucificado, Señor Calvario.

La comitiva entra en el templo repleto. El piso está cubierto de hojas de pino y axocopa. Al llegar hasta al pie de la cruz, que sacristanes y mayordomos han logrado sostener verticalmente, afianzada en el suelo, sacan a la imagen del ataúd, la incorporan y se percibe la intensidad emotiva de este momento para los asistentes, puesto que se manipula a la personificación de un difunto. Suenan las matracas, el aroma del incienso invade el recinto hasta que terminan de plano de incorporar a la pesada imagen. Los "jurios grandes" son quienes se encargan de levantar a Santo Entierro, de convertirlo en Señor Calvario y de crucificarlo. Para ello le han quitado el paño amarillo que cubre la cabeza del difunto para colocarle una peluca de cabellos largos y una corona de espinas. Aumenta la tensión y la emotividad del momento cuando parece claro para la gente que Señor Calvario se resiste a ser crucificado, puesto que al tratar de sostenerlo empotrado en la cruz de madera, ésta se inclina hacia atrás, perdiendo el equilibrio. Se consigue sostenerla en pie con la imagen crucificada después de varios intentos.

Queda por fin el Cristo crucificado y la trompeta y las matracas lo anuncian estrepitosamente. Sacan de sus nichos a las réplicas mayores de la Virgen Verónica, la Dolorosa y de San Juan Apóstol y colocan a cada una de estas imágenes custodiando al crucificado; permanecen ahi con cantos y alabanzas hasta que llega el sacerdote para celebrar la misa.

La celebración litúrgica transcurre mientras afuera hay gente que departe amistosamente. El sermón del sacerdote es largo e insiste en la inconveniencia de adorar al Cristo muerto. Mujeres con sus niños en brazos, como si fueran una entidad inseparable, están sentadas en el piso, imperturbables ante las palabras del cura. Una vez que concluye la celebración litúrgica, se inicia un nuevo episodio: el regreso del Cristo a su sepulcro. Lo bajan de nuevo, lo despojan de la peluca y la corona de espinas y le colocan el paño amarillo en la cabeza, prenda que lo convierte de nuevo en un difunto. Suenan matracas y trompeta y el incienso vuelve a invadir copiosamente el ambiente. Cuando queda dentro del féretro de nuevo, se inicia otra procesión que ahora es encabezada por catorce "jurios".

El primero de ellos lleva un caparazón de tortuga que tañe monótonamente. Los "jurios" ahora llevan paxtli en la cabeza y hombros y proyectan un aspecto terrorifico, llevan garrochas pintadas de color morado. Atrás viene, en hombros de su mayordomo, San Miguel Arcángel, blandiendo su espada hacia el grupo de 
jurios, como estableciendo de este modo una frontera simbólica entre el bien y el mal, entre la vida y la muerte. Los "jurios chicos" llevan los objetos utilizados en la Crucifixión, para retornarlos a su sitio en la Capilla del Señor Calvario. Atrás de San Miguel Arcángel, viene Santo Entierro, antecedido por la parafernalia de toda procesión (como si ésta comenzara aquí y no con los "jurios"): matracas, incensario, trompeta y Cruz Alta. Luego vienen las imágenes de La Dolorosa y la Virgen Verónica, vestidas de negro, en hombros de su respectivo mayordomo y sus Tlakechpanoke o cargadores. Cierran la procesión los Trece Apóstoles.

Rodean el templo para volver a entrar en él y los "jurios" desaparecen de la escena. Se coloca entonces la imagen de Santo Entierro frente al altar mayor. El féretro permanece abierto, a la disposición de quienes se acercan a adorar a la imagen del difunto. Son las cuatro de la tarde y los Apóstoles no han probado alimento desde la Ultima Cena, custodian el feretro mientras la gente se acerca a venerar a la imagen. Después de un lapso de tiempo, irán a colocarlo a la capilla del Señor Calvario, que es su sitio, y entonces por fin podrán comer. Sus mujeres los esperan con ollas y canastas, fuera de la capilla.

No terminan aqui las actividades rituales del Viernes Santo: los Apóstoles y mayordomos de todas las imágenes permanecerán durante la noche en la capilla del Señor Calvario, velando al difunto, cantando alabanzas monótonas e interminables. En el templo principal se encuentra la cruz ya vacia y junto a ella las imágenes de La Dolorosa, La Verónica y San Juan, con cirios y veladoras en el piso, representando su propio duelo. Será noche de vigilia para los funcionarios religiosos, pues a las cuatro de la mañana se realizará una nueva procesión. Aún entrada la noche, la gente del pueblo, circula de uno a otro templo, venerando a las imágenes dolientes y a Santo Entierro. Es primavera, hay luna llena y algunos muchachos conversan bajo su resplandor.

iii) Sábado Santo.

A las cuatro de la mañana se realiza la procesión para representar el entierro de Jesús, antes de colocar en su sitio a las imágenes que participaron en el episodio de la Crucifixión. Sacan del templo la Cruz donde Señor Calvario murió el día de ayer, a la Dolorosa, a la Virgen Verónica y a San Juan Apóstol, y los llevan de nuevo en procesión por el mismo circuito ceremonial, alrededor del templo. Los mayordomos y los trece Apóstoles que velaron al difunto durante la noche, se encargan ahora de colocar a dichas imágenes en su sitio.

Cuando amanece, los mayordomos sacan del templo las escasas bancas de madera que contiene para que las muchachas y niñas del coro limpien el piso, que ayer estuvo cubierto de axocopa y juncia, mientras un joven duerme sobre 
una banca en la capilla del señor Calvario, recuperándose del desvelo. El atrio y el templo deben quedar limpios para la celebración del Cirio Pascual que se realizará por la noche.

La capilla del Señor Calvario permanecerá abierta hasta entonces, con las veladoras encendidas frente a la figura del Santo Entierro, lo cual indica que este episodio ritual aún no concluye, que el tiempo festivo en este espacio público continuará hasta el domingo, para proseguir después en las esferas domésticas de los mayordomos que el siguiente año financiarän los gastos de las festividades de Semana Santa.

En la casa del mayordomo del Señor de la Resurrección hay música de banda y de cuerdas. Este sábado -la vispera de la entrega formal de su cargo que se celebrará durante la misa del Domingo de Pascua- se desarrolla la comida principal de todo su ciclo anual que ahora culmina. Será el día de hoy el banquete de entrega del cargo. Los teachkame o colaboradores del mayordomo son los invitados de honor, puesto que fueron ellos quienes cooperaron para la compra del animal que ahora se consume. Después de la comida comienza el baile en el interior de la pequeña habitación, frente al altar donde se encuentra la imagen festejada, acompañada por sus santos huéspedes. No se baila en parejas, sino que de forma individual los invitados se desplazan cadenciosamente al ritmo de los sones tradicionales que se desprenden del violin y los otros instrumentos de cuerdas. Se intercalan los acordes de la banda, mientras la gente baila y bebe hasta poco antes de las siete de la noche, hora en que se iniciará la misa en la iglesia, en la cual estará presente la imagen de El señor de la Resurrección. Los cohetes de pólvora anuncian que es casi la hora en que la comitiva del mayordomo se encaminará hasta el templo llevando a la imagen y precedida por la música de banda. Las mujeres llevan flores y cirios sin encender.

La pareja de mayordomos responsables de esta fiesta están agotados después de varios dias de trabajo atendiendo a sus invitados. Han permanecido en vigilia desde el día anterior, bebiendo y sin cambiarse de ropa como lo exige la costumbre. En este momento no se esmeran en arreglarse para ir a la iglesia, acuden así mismo y a los pocos minutos de iniciada la celebración litúrgica abandonan el templo; Feliciano, el mayordomo no soporta estar dentro del recinto repleto, después de la vigilia, el trabajo y la bebida consumida durante varios dias. Los Trece Apóstoles vuelven a aparecer en escena; entran al templo formados en dos filas, bajo el mando del Apóstol Mayor. Se realiza la ceremonia del Cirio Pascual a cargo del sacerdote. Después, la gente sale del templo y el silencio habitual de las noches de la montaña se altera con las cadenciosas melodias de la banda de aliento que toca en el atrio durante una hora. Esta 
banda está siendo financiada por el mayordomo del Señor de la Resurreción. Un año antes, él pagó la música para un compromiso de otro mayordomo, y éste, en retribución, ahora está devolviendo el préstamo. La noche es dulce y agradable, es primavera y el duelo por la muerte de Jesús ha terminado. La gente regresa a su casa con su vela encendida del gran cirio pascual. A las diez aún hay movimiento en el atrio; como pocos dias en el año, se encuentran por ahi habitantes de la cabecera y de las congregaciones de Atetekoxko, Zacamilola y Cuautlamanca, las más cercanas.

iiii) Domingo de Pascua.

En esta mañana, antes de la misa que iniciará a las diez, el ambiente se percibe más alegre y festivo. No es que haya más música o vendimia que el resto de la semana, sino que la gente fluye un poco más desde la montaña. Grupos de muchachas de Zacamilola, con sus trajes impecables, caminan por el centro ceremonial conversando y comprando golosinas. Toda la concurrencia, sin excepción, está arreglada con esmero y aparecen rostros que estuvieron ausentes el resto de la semana: son los jornaleros y vendedores ambulantes que regresaron para este dia allende la tierra caliente o la ciudad; también son los habitantes de Atlehuaya y Acultzinapa que no estuvieron presentes antes por la lejania de sus comunidades. Se siente por fin la consumación total del centro ceremonial como el punto unificador de los hijos de San Martin, como se autodenominan los habitantes de Atlahuilco.

La música de banda acercándose, anuncia que la comitiva del mayordomo que hoy entrega la imagen del Señor de la Resurrección, está a punto de protagonizar el momento culminante de su gestión anual. Dentro del templo, hay gente de pie o sentada en el piso, el coro de niñas ensaya cantos y un grupo de jóvenes de Atlehuaya, con guitarras y voces sonoras conceden emotividad al conjunto. El mayordomo lleva en sus manos la réplica menor de la imagen festejada, la réplica de tamaño intermedio la llevan dos hombres designados como Tepachtlanokemeh, mientras que la versión mayor de la imagen permanece dentro de la iglesia. Su comitiva está radiante; él y su esposa avanzan al centro de la misma, atraviesan el atrio y llegan hasta el altar mayor donde colocan las imágenes, incluyendo las de los santos acompañantes. La banda permanece fuera del templo.

Aún no comienza la misa. $\mathrm{El}$ atrio se puebla con grupos de mujeres con canastas y ollas de comida que se instalan bajo la sombra de un gran árbol de Laurel de la India. Ellas no entran a escuchar la misa, ya que como a parte de los asistentes, parece interesarles más el momento posterior a ésta, en que la gente comerá y departirá por grupos, invitada por cada uno de los mayordomos que cumplen un 
cargo en el ciclo ceremonial actual. En sus hogares se prepararon con anticipación tamales de frijol, atole de maiz y se adquirieron cervezas y aguardiente para compartirlos después de la misa.

A la entrada del templo se encuentra la imagen de San Martin Caballero. Los caminantes, antes que nada, se acercan a reverenciarla, encienden veladoras y ofercen monedas. Por fin comienza la misa: repiques de campanas, matracas, humo de incienso. Todas las imágenes de los santos que descansan alineadas a los costados del templo están adornadas con collares de margaritas blancas. Brilla el cabello negro de cientos de mujeres que se han peinado con aceite y adornado con pasadores y listones. Las faldas y los rebozos también son negros, pero las blusas de satin con encaje son blancas, verdes, amarillas, rosas. El coro de los jóvenes de Atlehuaya es vigoroso y opaca a las voces pequeñas de las niñas de Atlahuilco. El sacerdote se esmera otra vez en transmitir la alegria por la Resurrección de Jesús. Cristo. Los Trece Apóstoles también están presentes en este último episodio de la Semana Santa.

Al final, salen en procesión todas las imágenes de la iglesia -sus réplicas de mayor tamaño- llevadas en hombros por los Tepachtlanokemeh de los mayordomos vigentes en el ciclo actual. Siguiendo a la danza de Los Tocotines, desfilan los santos, los estandartes, las mujeres con ramos de flores, y rodean la iglesia en sentido opuesto a las manecillas del reloj. Pareciera que con este desfile se simbolizara la renovación del pacto entre todos los asistentes, incluidas las imágenes de los santos, para sostener un ciclo que sólo termina para volver a comenzar ininterrumpidamente. Los "jurios" -personajes del mal- se han ausentado y Padre Jesús Nazareno, Santo Entierro y Señor Calvario han vuelto a su lugar, concluyendo el duelo y la discordia.

Despuès de la procesión que cierra de nuevo el circuito ceremonial, llega el momento del disfrute y el goce. Sentadas en el suelo, las mujeres de los mayordomos ofrecen tamales de frijol y ellos, botellas de cerveza y copitas de aguardiente a sus amigos, parientes y colaboradores. Las notas de la banda se desprenden desde un extremo del atrio. Dentro del templo se encuentra de nuevo la imagen del Santo Entierro, colocada en el centro y con la tapa abierta, para ser tocada y contemplada de cerca. Tal parece que se ha pasado por alto el vehemente sermón del sacerdote, su regocijo por la Resurrección de Jesús, su invitación a celebrar la vida y no la muerte. Una vez que él se ha ausentado del pueblo los Trece Apóstoles sacan a la imagen de su sitio -la capilla del Señor Calvario- para colocarla en el centro de la iglesia principal, a la disposición de los caminantes y feligreses de todo el municipio.

El coro de Atlehuaya continúa cantando glorias y alabanzas, venerando al Santo 
Entierro, mientras los Apóstoles custodian la imagen y en el atrio la gente disfruta de los alimentos y la música. Mujeres y hombres de las rancherias se acercan a colocar monedas y veladoras al interior del ataúd, después de haberse "limpiado" el cuerpo con ellas. Acercan a niños y niñas para frotar su cuerpo con las veladoras y monedas y garantizar asi salud y protección. Es preciso aprovechar esta ocasión, puesto que el ataúd se cerrará dentro de unos momentos para permanecer asi hasta el siguiente año. Santo Entierro y San Martín Caballero permanecen en escena en este momento, recibiendo las plegarias de los feligreses que vinieron de visita a su centro ceremonial para la última y más importante celebración de la Semana Santa.

La fiesta continúa. En la pequeña explanada que hace de atrio de la capilla de Señor Calvario también hay gente departiendo. Entran y salen de la pequeña habitación contigua donde mujeres de Zacamilola se han instalado a descansar y a ofrecer comida y bebida a su círculo más inmediato. Son la comitiva del mayordomo saliente de Santo Entierro. Antes de partir, "Los Luceros de Cristo", el coro de Atlehuaya, se despiden de las imágenes de la capilla, anticipándose a la caida de la tarde.

Las reuniones en el centro ceremonial se disuelven casi al atardecer. Los caminantes toman su rumbos y senderos. Muchos hombres están bebidos; los más jóvenes gritan por el camino, parecen gritos de desahogo, o de desafio. Mientras tanto, en la casa del mayordomo que recibe el cargo de la imagen del Señor de la Resurrección, se preparan para el recibimiento. Se han preparado durante dias. El hombre que recibe el cargo vive muy cerca del centro del pueblo; es conocido por haber ocupado varios cargos religiosos a lo largo de su vida (entre ellos el de Apóstol Mayor), y durante todo el dia ha circulado la noticia de que por la tarde iniciará la fiesta en su hogar. Los Tocotines encabezan la procesión que lleva a la casa del nuevo mayordomo la imagen del santo que horas antes entregara Feliciano. Mucha gente acompaña el recibimiento.

En la casa de Remigio están listas las viandas de café, arroz y frijoles para los invitados. Las mujeres también han ensartado montones de margaritas para formar los xochikoskameh que colocarán en la imagen del Señor de la Resurrección y sus imágenes acompañantes antes de que traspongan el umbral del Santohkalli; también han deshojado rosas de castilla y formado xochimanalmeh, pequeños ramilletes de flores y hojas de naranjo, para entregar a los principales funcionarios que entrarán en la casa. El ritual de recibimiento es largo. Cuando se concluye por fin, pueden entrar todos al santohkalli, donde se ubicarán las imágenes, con todas las reverencias. Los anfitriones se esmeran en atender a la muchedumbre que casi no cabe en el recinto. Circula el aguardiente y la cerveza y comienza el baile. Muchos 
asistentes terminan de emborracharse por completo.

Al siguiente día del arribo de la imagen a la casa del nuevo mayordomo (el lunes de la nueva semana), se retiran todos los collares de flores colocados el dia anterior a las imágenes recién llegadas. Serán colocados en una canasta, junto con los pétalos de rosas, para después llevar a cabo la danza ceremonial llamada "baile del xochikoskatt" que celebra el inicio del ciclo que cumplirá la imagen en este hogar. 


\section{BIBLIOGRAFIA}

ADAMS, Richard. 1995. Etnias en Evolución Social. Estudios de Guatemala y Centroamérica. México, Universidad Autónoma Metropolitana, Unidad Iztapalapa, DCSH, Depto. de Antropologia.

AGUIRRE Beltrán, Gonzalo. 1957. El Proceso de Aculturación. México, UNAM.

1980. Medicina y Magia. El proceso de aculturación en la estructura colonial. México, Instituto Nacional Indigenista, COL: SEP-INI, No. 1

1986. Zongolica. Encuentro de Dioses y Santos

Patronos. Xalapa, Universidad Veracruzana.

1991. Regiones de Refugio. México, INI-FCEUniversidad Veracruzana-Gob. del Edo. de Veracruz. Col. Obra Antropológica, Tomo IX.

1991b. Formas de Gobierno Indigena. México, INIFCE-Universidad Veracruzana-Gob. del Edo. de Veracruz. Col. Obra Antropológica, Tomo IV.

1992. Pobladores del Papaloapan. Biografia de una Hoya. México, CIESAS, Ed. de la Casa Chata.

la Tierra. México, CIESAS.

1995. Cuatro Nobles Titulados en Contienda por

ALARCON Román, Lorena. 1986. Aspectos de la Inestabilidad

Morfosintáctica del Municipio de Los Reyes, Ver. Xalapa, Universidad Veracruzana (tesis de licenciatura en antropologia).

ALVAREZ Santiago, Héctor. 1991. El Xochitlali en San Andrés Mixtla. Xalapa, Gobierno del Estado de Veracruz, Col. V Centenario. 
ALVAREZ Santiago, Héctor y Maria Teresa RODRIGUEZ. 1991. "Las unidades domésticas de producción: estrategias de supervivencia de los campesinos nahuas de Zongolica", en: Boege (coord.), pp. 44-65 (inédito).

1992. "La apropiación de los recursos forestales en la tierra fria de la sierra de Zongolica", en: Desarrollo y Medio Ambiente en Veracruz. Xalapa, Instituto de Ecologia-Fundación F. Ebert- CIESAS-Golfo. pp. 169-177.

ANZURES Y BOLAÑOS, Maria del Carmen. 1990. "Tláloc, Señor del monte y dueño de los animales", en: Historia de la Religión en Mesoamérica y áreas afines. II Coloquio. (Barbro Dahlgren, ed.), México, IIA, UNAM. Pp. 121-158.

ARAMONI, Maria Elena. 1990. Tlalokan tata, tlalokan nana: nuestras raices. México, CONACULTA

ARIZPE Lourdes. 1973. Economia y Parentesco en una Comunidad Nahua. México, Instituto Nacional Indigenista.

BAEZ Galván, Félix. 1997. Tepahtiquetl. Alma, chamanismo y ritual entre los nahuas de Zacamilola. Universidad Veracruzana, Facultad de Antropologia, Tesis de Licenciatura.

BAEZ-Jorge, Félix. 1973. Los Zoque-Popolucas. Estructura Social, México, Instituto Nacional Indigenista.

Veracruzana.

1988. Los Oficios de las Diosas. Xalapa, Universidad

Veracruzana.

1998. Entre los Naguales y los Santos. Xalapa, Universidad

BALANDIER, Georges. 1990. El Desorden. La Teoria del Caos y las Ciencias Sociales. Barcelona, Ed. Gedisa.

BARJAU, Luis. 1972. Las Migraciones Indigenas al Ingenio Motzorongo, Ver. México, Escuela Nacional de Antropologia e Historia (tesis de maestria).

BARTH, Fredrick. 1979. Los Grupos Etnicos y sus Fronteras. México, Fondo de Cultura Económica.

BARTHES, Roland. 1990. "Introducción al análisis estructural de los relatos", en: Análisis Estructural del Relato (Barthes, Greimas et.al.). México, Ed. Premiá, 
pp. $7-38$.

BARTOLOME, Miguel A. 1992. "La identidad residencial en Mesoamérica". México, América Indigena, Vol II, Núm. 1-2.

Ed. Siglo XXI.

1997. Gente de Costumbre y Gente de Razón. México, INI-

BASTIAN, Jean-Pierre. 1997. La Mutación Religiosa en América Latina.

México, Fondo de Cultura Económica.

BELlO López, Daniel. 1996. El PRONASOL y las Nuevas Acciones del Indigenismo: El Fondo Regional de Solidaridad en la Sierra de Zongolica. Xalapa, Universidad Veracruzana (tesis de licenciatura en antropologia)

BOEGE, Eckart. 1988. Los Mazatecos ante la Nación. México, Ed. Siglo XXI. (coord.) 1991. Cultura, Naturaleza y Sociedad en la Sierra de Zongolica. Xalapa, INI-CIESAS, (mecanoscrito)

BONFIL, Guillermo. 1987. "La teoria del control cultural en el estudio de los procesos étnicos", en: Papeles de la Casa Chata. Mexico, SEP-CIESAS, Año 2, Núm. 3, pp. 23-43.

BORDIEU, Pierre. 1991. El Sentido Práctico. Madrid, Ed. Taurus.

BRETON, Alain. 1984. Bachajón. Organización Socioterritorial de una comunidad tzeltal. México, SEP-INI.

BRICKER, Victoria R. 1966. "El hombre la carga y el camino", en: Vogt (ed.), pp. 355-370. Cultura Económica.

1989. El Cristo Indigena, el Rey Nativo. México, Fondo de

BRODA, Johanna. 1969. The Mexican Calendar as Compared to other Mesoamerican Systems. Wien, Austria, Engelbert Stiglmayr.

BUCHLER, Ira. 1967. "Organización ceremonial de una aldea mexicana.", en: América Indigena, Vol XXVII, Núm. 2

BURKHART, Louise. 1989. The Slippery Earth. Nahua Christian Moral Dialogue in Sixteenth-Century Mexico. Tucson, University of Arizona Press. 
CAMARA, Fernando. 1996. "Organización Religiosa y Politica en Mesoamérica", en: Introducción al Sistema de Cargos. (Leif Korsbaek, comp.), México, Universidad Autónoma del Estado de México, pp. 113-159.

1952. "Religious and political organization", en: Sol Tax, Heritage of Conquest. Glencoe, III, pp. 142-164.

CANCIAN, Frank. 1976. Economia y Prestigio en una Comunidad Maya. México, Instituto Nacional Indigenista.

1990. "The zinacantan cargo waiting lists as a reflection of political and economic changes. 1952 to 1987", en: Stephen y Dow, ed., pp. 6376.

$215-228$.

1996. "The Hamlet as Mediator", en: Ethnology, Vol. 35, Núm. 3, pp.

CARDOSO DE OLIVEIRA, Roberto. 1992. Etnicidad y Estructura Social.

México, CIESAS, Ediciones de la Casa Chata.

CARMAGNANI, Marcello. 1988. El Regreso de los Dioses, México, Fondo de Cultura Económica.

CARRASCO, Pedro. 1979. "La jerarquia civicorreligiosa en las comunidades de Mesoamérica: antecedentes precolombinos y desarrollo colonial", en:

Antropologia Política, (J.R. Llobera, comp.), pp. 323-340.

1991. "La transformación de la cultura indigena durante la colonia", en: Los Pueblos de Indios y las Comunidades, México, El Colegio de México, Lecturas de Historia Mexicana, Núm. 2.

CASTAN Nicole, et.al. 1992. Historia de la Vida Privada. La Comunidad, el Estado y la Familia en los siglos XVI-XVIII. Madrid, Ed. Taurus.

CHAMOUX, Nöelle. 1987. Nahuas de Huauchinango, México, Instituto Nacional Indigenista.

CHANCE, John K. 1990. "Changes in Twentieth-Century Mesoamerican Cargo Systems", en: Class, Politics, and Popular Religion in Mexico and Central America., (Stephen y Dow, ed.) Washington. Society for Latin American Anthropological Publication Series, Volume 10, pp.27-42. 
CHANCE, John y William B. TAYLOR. 1987. "Cofradias y cargos: una perspectiva histórica de la jerarquia civico-religiosa mesoamericana", en: Antropologia suplemento. Boletín oficial del INAH. Nueva Epoca, Núm 14.

CHAVEZ Castillo, Sandra. 2000. "Los curas pusimos las costumbres y las podemos cambiar", en: Alteridades, México, UAM-Iztapalapa, Depto. de Antropologia, Año 10, Núm. 19, pp. 69-78.

CHIMALHUA, Benito e Isabel Ixmatlahua. 1988. El maiz en la cocina de Atlahuilco y Tepepa. Dirección General de Culturas Populares, Unidad Regional Centro de Veracruz. Serie Tlatolli, Núm. 2.

CHIMALHUA, Benito, Isabel IXMATLAHUA, et. al. 1989. Alimentación Tradicional entre los Nahuas de Zongolica: Compilación de Recetas. Dirección General de Culturas Populares, Unidad Regional Centro del Estado de Veracruz. Serie Tlatolli, Núm. 3.

COLLIER, George. 1976. Planos de Interacción del Mundo Tzotzil. México, Instituto Nacional Indigenista, colección SEP-INI.

COLLIER, Jane. 1995. "Problemas teórico-metodológicos en la antropologia juridica", en: Pueblos indigenas ante el derecho, Victoria Chenaut y Maria Teresa Sierra (coords.), pp. 45-72

COHEN, Abner. 1985. "Antropologia Politica: el análisis del simbolismo en las relaciones de poder", en: Llobera (ed.) Antropología Politica. Barcelona, Ed. Anagrama, pp. 55-82.

CONAPO. 1993. Consejo Nacional de Población. Sistema Automatizado de Información sobre la Marginación en México.

DE LA FUENTE, Julio. 1949. Yalalag: Una villa zapoteca serrana. México, Museo Nacional de Antropologia, Serie Cientifica, Núm 1.

DEHOUVE, Danielle. 1976. El Tequio de los Santos y la Competencia entre los Mercaderes. México, Instituto Nacional Indigenista, Col. SEP-INI, Núm. 43.

DEVEREUX, George, 1977. De la Ansiedad al Método en las Ciencias del Comportamiento. México, Ed. Siglo XXI.

DE VOS, Jan. 1998. "De la costumbre colonial a los credos modernos: el proceso de mutación religiosa entre los mayas de Chiapas y Guatemala". (mcs). 
DIAZ Cruz, Rodrigo. 1995. Archipiélago de Rituales. Cinco Teorias

Antropológicas de Ritual. México, Universidad Nacional Autónoma de México. Tesis de doctorado

1997. "La vivencia en circulación. Una introducción a la antropologia de la experiencia", en: Alteridades, Universidad Autónoma Metropolitana, Unidad Iztapalapa, Núm 13, pp. 5-15.

DOW, James. 1974. Santos y Supervivencias: Funciones de la Religión en una Comunidad Otomi. México, Instituto Nacional Indigenista.

DURAN, Fray Diego. 1965. Historia de las Indias de Nueva España y Islas de Tierra Firme. México, Ed. Nacional.

DUVERGER, Christian. 1983. La Flor Letal. Economia del Sacrificio Azteca. México, Fondo de Cultura Económica.

DUVIGNAUD, Jean. 1997. El Sacrificio Inútil. México, Fondo de Cultura Económica.

EARLE, Duncan. 1990. "Appropiating the enemy: Highland Maya Religious Organization and Community Survival", en: Stephen y Dow (ed.), pp. 115-142.

EARLY, Daniel K. 1982. Café: Dependencia y Efectos: Comunidades Nahuas de Zongolica en el mercado de Nueva York. México, Instituto Nacional Indigenista.

ESCALANTE Gonzalbo, Paloma. 1998. "Agentes de pastoral indigena en las diócesis de Tehuantepec, Oaxaca y San Cristóbal de las Casas, Chiapas. Un recorrido desde dentro", en: Revista Académica para el Estudio de las Religiones. Tomo Dos, pp. 131-148.

FAVRE, Henri. 1984. Cambio y Continuidad entre los mayas de México. México, Instituto Nacional Indigenista.

FLORESCANO, Enrique. 1986. Origen y Desarrollo de los Problemas Agrarios de México 1500-1821. México, Ed Era-SEP, Serie Lecturas Mexicanas, Nưm. 34.

1997. Etnia, Estado y Nación. México, Ed. Aguilar.

FOLADORI, Guillermo. 1975. La Proletarización del Campesino: Antropologia Económica de la Sierra de Zongolica, Veracruz. México, Escuela Nacional de 
Antropologia (tesis de licenciatura).

FORTUNY, Patricia. 1989. Religión y Sociedad en el Sureste de México.

México CIESAS, Cuadernos de la Casa Chata, Núm. 165, vol V.

FOSTER, George M. 1962. Cultura y Conquista: la herencia española de América. Xalapa, Universidad Veracruzana.

FRAZER, James. 1946. El Totemismo. Estudio de Etnografia Comparada. Buenos Aires, Ed. Kier.

FRIEDLANDER, Judith. 1981. "The secularization of the cargo system. An exemple from post-revolucionary México", en: Latin American Research Review, Vol. 16, pp. 132-142.

GALINIER, Jacques. 1990. La Mitad del Mundo. Cuerpo y Cosmos en los Rituales Otomies. México, UNAM, CEMCA, INI.

GARCIA Canclini, Néstor. 1990. Culturas Híbridas. Estrategias para entrar y salir de la modernidad. México, CONACULTA- Ed. Grijalbo.

Paidós.

1999. La Globalización Imaginada. México, Ed.

GARCIA de León, Antonio. 1969. "El universo de lo sobrenatural entre los nahuas de Pajapan, Veracruz", en: Estudios de Cultura Náhuatl. UNAM, IIH. Vol, VIII, pp. 279-312.

GARCIA López, Marcelina. s/a. Estudio Epidemiológico y de Medicina Tradicional en un área de la región de Zongolica, Veracruz. Xalapa, CIESAS-Golfo. (mcs.).

GARCIA López, María. 1995. Tlahtolli itech nahuatl wan español altepetl Zongolica-Vocabulario náhuatl-español de la Sierra de Zongolica (trabajo práctico educativo). Xalapa, Universidad Veracruzana (tesis de licenciatura en antropologia)

GARCIA Martinez, Bernardo. 1987. Los Pueblos de la Sierra. El Poder y el Espacio entre los Indios del Norte de Puebla hasta 1700. México, El Colegio de México.

GARCIA Méndez, Andrés. 1998. "Actividad politica en indígenas evangélicos de Chiapas", en: Revista Académica para el Estudio de las Religiones, Tomo 
Dos, pp. 293-308.

GARMA Navarro, Carlos. 1987. Protestantismo en una Comunidad Totonaca de Puebla, México. México, Instituto Nacional Indigenista, Serie de Antropologia Social, Núm. 76.

GERHARD, Peter. 1991, "Congregaciones de Indios en la Nueva España antes de 1570", en: Los Pueblos de Indios y las Comunidades. México, EL Colegio de México., Lecturas de Historia Mexicana, Núm. 2.

GELLNER, Ernest. 1991. Naciones y Nacionalismo. México, CONACULTAAlianza Editorial.

GERBI, Antonello. 1982. La Disputa del Nuevo Mundo. Historia de una Polémica 1750-1900. México, Fondo de Cultura Económica.

GIMENEZ, Gilberto. 1998. Identidades Etnicas: Estado de la Cuestión. (mcs.)

GODELIER, Maurice. 1989. Lo Ideal y lo Material. Pensamiento, Economias, Sociedades. Madrid, Ed. Taurus.

1998. El Enigma del Don. Barcelona, Ed. Paidós.

GOOD, Catherine. 1988. Haciendo la Lucha. Arte y Comercio entre los Nahuas de Guerrero. México, FCE.

GOSSEN, Gary H. 1979. Los Chamulas en el Mundo del Sol. México, INI.

GREENBERG. James B. 1981. Santiago's Sword, Berkeley, University of California, Press.

1990. "Sanctity and resistence in close corporate indigennous communities: coffee, money, violence, and ritual organization in chatino communities in Oaxaca", en: Stephen y Dow (ed.), pp. 95-114.

GUZMAN, Teódulo. s/a. "Comentarios", en: Vázquez (comp.) Primer Encuentro de Balance y Tendencias de las Agrupaciones Religiosas en Xalapa. CIESAS-DGCP. pp. 35-36.

GRIMES, Ronald. 1981. Simbolo y Conquista. Rituales y Teatro en Santa Fe, Nuevo México. México, Fondo de Cultura Económica. 
GRUZINSKI, Serge. 1995. La Guerra de las Imágenes. De Cristóbal Colón a Blade Runner (1492-2019). México, Fondo de Cultura Económica.

HARRIS, Marvin. 1964. Patterns of race in the Americas. New York, Walker and Company.

HASLER, Andrés. 1987. Hacia una Tipologia Morfológica del Nâhuatl. México, CIESAS, Cuadernos de la Casa Chata.

1996. El Náhuatl de Tehuacán-Zongolica. México, CIESAS.

HERNANDEZ Orellán, Severiano. 1999. El Centro Coordinador Indigenista de la Sierra Nahuatl de Zongolica. Recapitulación, Reflexiones y Opiniones Criticas. (mcs.).

HERNANDEZ, Rosalba Aida. 1994. "Identidades colectivas en los márgenes de la nación: etnicidad y cambio religioso entre los mames de Chiapas", en: Nueva Antropologia, Revista de Ciencias Sociales, México, vol. XIII, núm. 45, pp. 83106.

1998. "De la sierra a la selva: Identidades étnicas y religiosas en la frontera sur", en: (Viqueira y Ruz, coords.) Chiapas Los Rumbos de Otra Historia. México, UNAM-CEMCA-CIESAS-U de G., pp. 407-424.

HOFFMAN, Odile y Fernando I. SALMERON (coords.). 1997. Nueve Estudios sobre el Espacio. Representación y formas de apropiación. México. CIESASORSTOM.

HUERTA Rios, César. 1981. Organización Sociopolítica de una Minoria Nacional. Los Triquis de Oaxaca, México, Instituto Nacional Indigenista, col. SEP-INI, Núm 62.

HULSEWIEDE, Briggitte. 1992. Die Nahua von Tequila. Münster/Hamburg: Lit Verlag

1998. Die Mayordomias in Tequila. Münster: Lit

HUNT, Eva y June NASH. 1975. "Local and Territorial Units", en: Handbook of Middle American Indians. Austin, University of Texas Press, Vol. 6, pp. 253282.

ICHON, Alain. 1973. La Religión de los Totonacas de la Sierra. México, 
Instituto Nacional Indigenista.

INEGI. 1995. Conteo de Población 1995. Instituto Nacional de Estadística, Geografia e Informática. México.

IXMATLAHUA, Isabel. 1988. "Los dueños de la tierra y el cazador", Tlatolli, Xalapa, Unidad Regional Centro de Veracruz, Dirección General de Culturas Populares, Núm. 1

JACOME, Cruz. 1972. Hombre y Economia en Zongolica. Xalapa, Universidad Veracruzana (tesis de maestria en antropologia).

KIRCHHOFF, Paul. 1992. "Mesoamérica. Sus límites geográficos, composición étnica y caracteres culturales". En: Una definición de Mesoamérica (Vivó, Litvak et. al.), México, UNAM-IIA, pp. 28-45.

Paul KIRCHHOFF, Lina ODENA y Luis REYES. 1976. Historia Tolteca-

Chichimeca. (Trad. Luis Reyes), México, INAH-CICINAH, SEP.

KORSBAEK, Leif (comp.). 1996. Introducción al Sistema de Cargos. Toluca, Universidad Autónoma del Estado de México.

KORSBAEK, Leif. 1996. "El típico sistema de cargos", en: Korsbaek (comp.), pp. 67-85.

KROTZ, Esteban (comp.) 1993. La Cultura Adjetivada. México, Universidad Autónoma Metropolitana, Depto. de Antropologia.

1993. "El concepto "cultura" y la antropologia mexicana: ¿Una tensión permanente?”, en: Krotz (comp.), México Universidad Autónoma Metropolitana, Unidad Iztapalapa. Depto. de Antropologia, pp. 13-31.

LAFAYE, Jacques. 1985. Quetzalcóatl y Guadalupe. México, Fondo de Cultura Económica.

LEACH, Edmund. 1987. Cultura y Comunicación. La Lógica de la Conexión de los Simbolos. Madrid, Ed. Siglo XXI.

\section{Sistemas Politicos de la Alta Birmania.}

Barcelona, Ed. Anagrama.

LEVI-STRAUSS, Claude. 1964. El Pensamiento Salvaje. México, Fondo de Cultura Económica. 
LEWELLEN, Ted C. 1985. Antropologia Politica. Barcelona, Ed. Bellatera.

LEWIS, Oscar. 1951. Life in a Mexican VIllage: Tepoztlán Restudied. Urbana, Illinois.

LEYVA Solano, Xóchitl. 1998. "Catequistas, misioneros y tradiciones en Las Cañadas", en: (Viquiera y Ruz, coords.) Chiapas Los Rumbos de Otra Historia, UNAM-CEMCA-CIESAS-U de G., pp. 375-406.

LITVAK, Jaime. 1992. "En torno al problema de la definición de Mesoamérica", en: Una definición de Mesoamérica (Vivó, Litvak et. al.), pp. 74-102.

LOMNITZ, Claudio. 1999. Modernidad Indiana. México, Ed. Planeta.

LOPEZ ARELLANO, José. 1977. Efectos de la Semiproletarización en una Zona Indigena en la Sierra de Zongolica. México, Escuela Nacional de Antropologia (tesis de licenciatura)

LOPEZ Austin, Alfredo. 1973. Hombre-Dios. Religión y Politica en el Mundo Náhuatl. México, UNAM-IIH.

1980. Cuerpo Humano e Ideologia. Las concepciones de los antiguos nahuas. México, UNAM- IIA.

1990. Los Mitos del Tlacuache. México, Alianza Editorial

Mexicana.

Económica.

1994.Tamoanchan y Tlalocan. México, Fondo de Cultura

LOCKHART, James. 1996. The Nahuas after de Conquest. Stanford University Press.

LUNA PEÑA, Bertha Alicia. 1988. Clasificación Semántica de Plantas y Animales en el Nảhuatl de Cotlaixco. Xalapa, Universidad Veracruzana (tesis de licenciatura en antropologia).

MAC NEISH, Richard. 1964. El origen de la Civilización Mesoamericana vista desde Tehaucán. México, INAH.

MACUIXTLE, Julio. 1986. La Importancia de la Bebida en la Vida Social del Municipio de Magdalena en la Región de Zongolica, Ver. Xalapa, Universidad Veracruzana (tesis de licenciatura en antropologia). 
MADSEN, William. 1975. "Religious Sincretism". Handbook of Middle

American Indians. Austin, University of Texas Press. Vol. 6. pp. 369-391.

MARION, Marie-Odile. 1998. "Religión, identidad y rebelión en las Cañadas", en:

Revista Académica para el Estudio de las Religiones, Tomo Dos, pp. 19-32.

MARZAL, Manuel. 1996. "The Religion of the Andean Quechua in Southern Peru", en: The Indian Face of God in Latin America (Marzal, Maurer et. al.), New York, Orbis Books, pp. 67-118.

MATOS, Eduardo. 1995. "Mesoamérica", en: Historia Antigua de México. (Linda Manzanilla y Leonardo Lopez, coords.). México, Instituto Nacional de Antropologia e Historia, UNAM, Ed. Porrúa. Vol. I, pp. 49-73.

MAURER, Eugenio. 1996. "Tseltal Christianity", en: The Indian Face of God in Latin America. (Marzal, Maurer et. al.), pp. 23-63.

MEDINA, Andrés. 1986. "Ortodoxia y herejia en la antropologia mexicana", en: La Quiebra Politica de la Antropologia Social en México (García Mora y Medina, ed.). México, Universidad Nacional Autónoma de México, Serie Antropológica, Tomo II, pp, 129-142.

1987. "Los que tienen el don de ver: los sistemas de cargos y los hombres de conocimiento en los Altos de Chiapas", en: Barbro Dahlgren (ed.), Historia de la Religión en Mesoamérica y Areas Afines (Primer Coloquio), Mëxico, UNAM, pp. 153-175.

\section{Tenejapa: familia y tradición en un pueblo tzeltal.}

México. Gobierno del Edo. de Chiapas.

1995. "Los sistemas de cargos en la Cuenca de México", en: Alteridades. México, Universidad Autónoma Metropolitana, Unidad Iztapalapa, Año 5, Núm 9, pp. 7-23.

1996. "Prólogo", en: Korsbaek, 1996, pp. 7-29.

1996b. "El trabajo de campo en la antropologia mexicana: una revisión de trabajos recientes", en: Inventario Antropológico, Anuario de la Revista Alteridades, Universidad Autónoma Metropolitana, Unidad Iztapalapa, Depto. de Antropologia, pp. 13-45.

MENDEZ, Sabino. 1988. La Migración como Alternativa de Subsistencia: el 
caso de Tehuipango, Ver. Xalapa, Universidad Veracruzana (tesis de licenciatura en antropologia).

MILlan, Saúl. 1993. La Ceremonia Perpetua, México, Instituto Nacional Indigenista.

MONZON, Arturo. 1983. El Calpulli en la Organización Social de los Tenochca, México, INI.

MONZON, Cristina. 1990._Registro de la Variación Fonológica en el Náhuatl Moderno. Un estudio de caso. México, CIESAS, Ed. de la Casa Chata, No. 34.

MORENO, Isidoro. 1985. Cofradias y Hermandades Andaluzas. Andalucia, Ed. Andaluzas Unidas, S.A. Biblioteca de la Cultura Andaluza, Núm 17.

MULHARE, Eileen. 1996. "Barrio Matters: Toward an Ethnology of Mesoamerican Customary Social Units" en: Ethnology, Vol. 35, Núm. 2, pp. 93-106.

NAHMAD, Salomón. 1998. "Guillermo Bonfil, un visionario de la sociedad multiétnica mexicana en el siglo XXI" (mcs.).

NASH, June. 1975. Bajo la Mirada de los antepasados. México, Instituto Indigensita Interamericano, Ed. Especiales. Núm 71.

1958. "Political relations in Guatemala", Social and Economic Studies, Vol. VII, Kingston, pp. 65-75.

NASH, Manning. 1996. "Las relaciones politicas en Guatemala", (trad. Leif Korsbaek), en: Korsbaek (comp.), pp. 161-173.

NADER, Laura. 1964. Talea and Juquila: a Comparizon of Zapotec Social Organization. Publications en American Archeology and Ethnography, No. 48, pp. 155-296. Berckeley, University of California.

NUTINI, Hugo. 1968. San Bernardino Contla. Pittsburgh, University of Pittsburgh Press.

1988. Todos Santos in Rural Tlaxcala. A syncretic, expressive, and symbolic analysis of the dead. Princeton University Press.

NUTINI, Hugo y Betty BELL. 1974. Los Pueblos de Habla Náhuatl de la Región de Tlaxcala y Puebla. México, Instituto Nacional Indigenista. 
Eonómica.

1989. Parentesco Ritual. México, Fondo de Cultura

OCHIAI, Kazuyasu. 1985. Cuando los Santos Vienen Marchando. Rituales

Públicos Intercomunitarios Tzotziles. San Cristóbal de las Casas, Chiapas, Universidad Autónoma de Chiapas. Centro de Estudios Indigenas. Serie Monografias, Núm. 3.

OEMINCHEN, Cristina. s/f. El Indigenismo en el Proceso de Reforma del Estado (mcs.).

OETTINGER, Marion. 1980. Una Comunidad Tlapaneca, sus linderos sociales y territoriales. México, Instituto Nacional Indigensita, col. SEP-INI, Núm. 61.

OREA, Manuel. 1989. “¿Les cuento? ... ¡Si les cuento!”, en: Tlatolli, Xalapa, Unidad Regional Centro de Veracruz. Dirección General de Culturas Populares, Núm. 4

ORTIZ Espejel, Benjamin. 1991. "Los paisajes naturales en la sierra de Zongolica", en: Boege (coord.), pp. 8-22.

PANIAGUA, Zoraya. 1986. El Cuadro Clasificatorio del Verbo en el Dialecto de Xochiojca y en el Náhuatl Clásico. Xalapa, Universidad Veracruzana (tesis de licenciatura).

PARKER. Christian. 1994. Otra Lógica en América Latina. Religión Popular y Modernización. México, Fondo de Cultura Económica.

PITARCH, Pedro. 1996. Ch'ulel: Una Etnografia de las Almas Tzeltales. México, Fondo de Cultura Económica.

POZAS Arciénegas, Ricardo. 1987. Chamula: un pueblo indio de los Altos de Chiapas. México, Instituto Nacional Indigenista.

PORTAL, Maria Ana. 1996. "El concepto de cosmovisión desde la antropologia mexicana contemporánea", en: Inventario Antropológico, UAM-Iztapalapa, Depto. de Antropología, Volumen 2, pp. 59-83.

QUEZADA, Nohemi. 1989. Enfermedad y Maleficio. México, UNAM.

RADCLIFFE-BROWN, A.R. 1975. El Método de la Antropologia Social. Barcelona, Ed. Anagrama. 
REDFIELD, Robert. 1941. Tepoztlán. A mexican village: a study of folk life. Chicago, University of Chicago.

REDFIELD, Robert y Alfonso VILLA ROJAS. 1934. Chan Kom: a Maya Village. Chicago, Phoenix Books.

REYES Garcia, Luis. 1963. La tierra en el desarrollo histórico de Zongolica. Xalapa, Instituto de Antropologia, Universidad Veracruzana. Mcs.

1990. "Introducción", en: El Anillo de Tlalocan (Reyes Garcia y Dieter Christensen, coords.), México, CIESAS- Fondo de Cultura Económica, Gob. Del Edo. de Puebla. pp. 15-27

REYNOSO, Carlos. 1991. "Presentación”, en: El Surgimiento de la Antropologia Posmoderna (Reynoso, comp.), Barcelona, Ed. Gedisa, pp. 11-60.

RIVERA Farfán, Carolina. 1998. "La diáspora religiosa en Chiapas, notas para su estudio", en: Revista Académica para el Estudio de las Religiones, Tomo Dos, pp. $173-188$.

RODRIGUEZ López, Maria Teresa. 1988. Preservación de la Lengua Materna en San Juan Texhuacan, Veracruz. México, Instituto Nacional Indigenista. Serie de Antropologia Social, Núm. 78.

1993. Grupos Domésticos y Organización Ceremonial en Atlahuilco, Veracruz. Xalapa, CIESAS-Golfo, tesis de maestria en antropologia social.

1995. "Sistema de Cargos y cambio religioso en la Sierra de Zongolica, Veracruz", en: $\quad$ Alteridades, México, Universidad Autónoma Metropolitana, Unidad Iztapalapa, año 5, Núm. 9, pp. 63-69.

1995b. "Estrategias de subsistencia y patrones residenciales: transformaciones en la organización doméstica de un pueblo nahua del centro de Veracruz", en: Romero y Jiménez (coords.), pp. 53-65.

1995c. "La lucha por la subsistencia: movilidad y arraigo en los pueblos nahuas de la Sierra de Zongolica, Veracruz", en: Romero y Jiménez (coords.), pp. 85-96.

ROMERO Osvaldo, 1989. La Castellanización Como Parte del Proceso de Migración Temporal: el Caso de Astacinga, Ver. Xalapa, Universidad Veracruzana (tesis de licenciatura en antropologia) 
1995. "Migración regional y cambio sociolingüistico entre los nahuas del centro de Veracruz", en: Romero y Jiménez (coords.), pp. 97-106.

ROMERO, Osvaldo y Raúl JIMENEZ, (coords.) 1995. Dos Regiones Nahuas de México. Universidad Autónoma de Tlaxcala. Centro Universitario de Estudios para la Familia.

ROSALDO, Renato. 1991. Cultura y Verdad. México, CONACULTA-Ed. Grijalbo.

ROTH Seneff, Andrew. 1993. "Región nacional y construcción de un medio cultural. El Año Nuevo P' urhépecha”, en: Relaciones. Estudios de Historia y Sociedad. El Colegio de Michoacán. Núm. 53, pp. 241-272.

ROTH Seneff, Andrew y Cristina MONZON. 1985. "Fronteras fonológicas de la Sierra de Zongolica y la Historia Tolteca-Chichimeca", en: Estudios de Cultura Náhuatl, Núm. 18.

ROTH Seneff, Andrew et. al. 1986. Lingüistica Aplicada y Sociolingüistica del Náhuatl en la Sierra de Zongolica. México, CIESAS, Cuadernos de la Casa Chata.

RUBIAL, Antonio. 1997. "Tierra de Prodigios. Lo maravilloso cristiano en la Nueva España de los siglos XVI y XVII", en: La Iglesia Católica en México (Nelly Sigaut, ed.), El Colegio de Michoacán- Secretaria de Gobernación. Pp. 357-379.

RUBIO, MIguel Angel. 1995. La Morada de los Santos. México, Instituto Nacional Indigenista-SEDESOL. Col. Fiestas de los Pueblos Indigenas.

RUS, Jan y Robert WASSERSTROM, 1980. "Civil-religious hierarchies in Central Chiapas: a critical perspective", en: American Ethnologist, pp. 466-478.

RUZ, Mario Humberto. 1997. "La familia divina: imaginario hagiográfico en el mundo maya”, en: La Iglesia Católica en México (Nelly Sigaut, ed.), El Colegio de Michoacán- Secretaría de Gobernación, pp. 381-405.

SAHAGUN, Fray Bernardino. 1988. Historia General de las Cosas de la Nueva España. Madrid. Ed. Alianza.

SANDSTROM, Alan. 1991. Corn is our Blood. Culture and Ethnic Identity in a Contemporary Aztec Indian Village. University of Oklahoma Press. 
1995. "Migración regional y cambio sociolingüistico entre los nahuas del centro de Veracruz", en: Romero y Jiménez (coords.), pp. 97-106.

ROMERO, Osvaldo y Raúl JIMENEZ, (coords.) 1995. Dos Regiones Nahuas de México. Universidad Autónoma de Tlaxcala. Centro Universitario de Estudios para la Familia.

ROSALDO, Renato. 1991. Cultura y Verdad. México, CONACULTA-Ed. Grijalbo.

ROTH Seneff, Andrew. 1993. "Región nacional y construcción de un medio cultural. El Año Nuevo P' urhépecha”, en: Relaciones. Estudios de Historia y Sociedad. El Colegio de Michoacán. Núm. 53, pp. 241-272.

ROTH Seneff, Andrew y Cristina MONZON. 1985. "Fronteras fonológicas de la Sierra de Zongolica y la Historia Tolteca-Chichimeca", en: Estudios de Cultura Náhuatl, Núm. 18.

ROTH Seneff, Andrew et. al. 1986. Lingüistica Aplicada y Sociolingüística del Náhuatl en la Sierra de Zongolica. México, CIESAS, Cuadernos de la Casa Chata.

RUBIAL, Antonio. 1997. "Tierra de Prodigios. Lo maravilloso cristiano en la Nueva España de los siglos XVI y XVII", en: La Iglesia Católica en México (Nelly Sigaut, ed.), El Colegio de Michoacán- Secretaria de Gobernación. Pp. 357-379.

RUBIO, MIguel Angel. 1995. La Morada de los Santos. México, Instituto Nacional Indigenista-SEDESOL. Col. Fiestas de los Pueblos Indigenas.

RUS, Jan y Robert WASSERSTROM, 1980. "Civil-religious hierarchies in Central Chiapas: a critical perspective", en: American Ethnologist, pp. 466-478.

RUZ, Mario Humberto. 1997. "La familia divina: imaginario hagiográfico en el mundo maya", en: La Iglesia Católica en México (Nelly Sigaut, ed.), El Colegio de Michoacán- Secretaria de Gobernación, pp. 381-405.

SAHAGUN, Fray Bernardino. 1988. Historia General de las Cosas de la Nueva España. Madrid. Ed. Alianza.

SANDSTROM, Alan. 1991. Corn is our Blood. Culture and Ethnic Identity in a Contemporary Aztec Indian Village. University of Oklahoma Press. 
1996. "Center and periphery in the social organization of contemporary nahuas of Mexico", en: Ethnology, vol. 35, Núm 3, pp. 161-180.

1997."Toponymic Groups and House Organization among the Nahuas of Northen Veracruz, Mexico" (en prensa) 39 págs.

1998. "El nene lloroso y el espíritu nahua del maiz: el cuerpo humano como simbolo clave en la Huasteca veracruzana", en: Nuevos Aportes al conocimiento de la Huasteca. (coord. Jesús Ruvalcaba), México, CIESASUACH-INI-CEMCA-IPN, pp. 59-94

SEGRE, Enzo. 1987. Las Máscaras de lo Sagrado. México, Instituto Nacional de Antropologia e Historia.

1990. Metamorfosis de lo Sagrado y de lo Profano. México, Instituto Nacional de Antropologia e Historia.

1994. "Globalización y modernidad", en: De lo Local a lo Global (Garcia Canclini, Signorelli et. al.). México, Universidad Autónoma Metropolitana, Unidad Iztapalapa. pp. 183-189.

SIGNORELLI, Amalia. 1994. "La construcción de lo local como valor y como ideologia. La experiencia de los emigrantes italianos", en: De lo Local a lo Global (Garcia Canclini, Signorelli, et. al.). México, Universidad Autónoma Metropolitana, Unidad Iztapalapa, pp. 39-66.

SIGNORINI, Italo y Alessandro LUPO. 1989. Los Tres Ejes de la Vida. Xalapa, Universidad Veracruzana.

SIMEON, Rémi. 1988. Diccionario de la Lengua Nahuatl o Mexicana.' México, Ed. Siglo XXI.

SMITH, Waldemar R. 1981. El Sistema de Fiestas y el Cambio Económico. México, Fondo de Cultura Económica.

SOUSTELLE, Georgette. 1958. Tequila: un Village Nahuatl du Mexique Oriental. Paris, Université de Paris. Institut D'Etnologie.

SOUSTELlE, Jacques. 1983. El Universo de los Aztecas. México, Fondo de Cultura Económica.

STEPHEN, Lynn. 1990. "The politics of ritual: the mexican state and zapotec 
autonomy, 1926 to 1989", en: Stephen y Dow (eds.), pp. 43-62.

STEPHEN, Lynn y James Dow. 1990. (eds.) Class, Politics, and Popular Religion in Mexico and Central America. Washington, Society for Latin American Anthropology Publication Series, Volume 10.

SWARTZ Marc, Víctor TURNER y Arthur TUDEN. 1994. "Antropologia Politica. Una Introducción", en: Alteridades. UAM- Iztapalapa, Depto. de Antropologia. Año 4, Núm. 8, pp. 101-126.

TANCK de Estrada, Dorothy. 1997. "Las tres principales fiestas religiosas en los pueblos de indios, según los reglamentos de los bienes de comunidad, 17651821", en: La Iglesia Católica en México. (Nelly Sigaut, ed.) México, EL Colegio de Michoacán- Secretaria de Gobernación, pp. 335-355.

TAGGART, James. 1975. Estructura de los Grupos Domésticos de una Comunidad de Habla Náhuat de Puebla. México, Instituto Nacional Indigenista. Col. SEP-INI, Núm. 41.

1975b. "Ideal" and "real" behavior in the mesoamerican nonresidential extended family", en: American Ethnologist, American Anthropological Association, Vol. 2, Núm. 2, pp. 347-357.

TAUSSIG. Michael. 1993. El Diablo y el Fetichismo de la Mercancia en Sudamérica. México, Ed. Nueva Imagen.

TAX, Sol. 1996. "Los Municipios del Altiplano Mesooccidental de Guatemala (1937)", en: Introducción al Sistema de Cargos, (Leif Korsbaek, comp.), México, Universidad Autónoma del Estado de México, pp. 87-112.

TORRES Mávil, José Martin. 1987. El Polimorfismo Fonético de las Lexias y la Evolución Fonológica del Náhuatl de Zongolica. Xalapa, Universidad Veracruzana (tesis de licenciatura en antropologia).

TÖNNIES, Ferdinand. 1947. Comunidad y Sociedad. Buenos Aires, Ed. Losada.

TRANFO, Luigi. 1974. Vida y Magia en un Pueblo Otomi del Mezquital. México, Instituto Nacional Indigenista.

TURNER, Víctor. 1980. La Selva de los Símbolos. Madrid, Ed. Siglo XXI.

VAZQUEZ Palacios, Felipe. 1985. Las Formas de Identidad Etnica Campesina en una Comunidad Nahua de la Región de Zongolica. México, Escuela 
Nacional de Antropologia (tesis de maestria en antropologia).

s/f. "La atracción del grupo Amistad de Xalapa, A.C.", en: Primer Encuentro de Balance y Tendencias de las Agrupaciones Religiosas en Xalapa. CIESAS-DGCP. pp. 32-35.

1991. Protestantismo en Xalapa. Xalapa, Gob. Del Estado de Veracruz, Col. V Centenario.

1995. "Idenitidad, Lengua y Campesinos en Zongolica", en: Romero y Jiménez (coords.), pp. 67-84.

VOGT, Evon Z. 1979. Ofrendas para los Dioses. México, Fondo de Cultura Económica.

VIQUIERA, Juan Pedro. 1997. "Exitos y fracasos de la evangelización en Chiapas", en: La Iglesia Católica en México. (Nelly Sigaut, ed.), México, El Colegio de Michoacán- Secretaria de Gobernación, pp. 69-98.

VILLA Rojas, Alfonso. 1987. Los Elegidos de Dios. Etnografia de los Mayas de Quintana Roo. México, Instituto Nacional Indigenista.

VOGT, Evon Z. 1976. "Prefacio", en: Cancian, 1976, pp. 13-15.

(ed.) 1980. Los Zinacantecos. México, Instituto Nacional Indigenista. Col de Antropologia Social, Núm. 7.

1980. "Algunos aspectos de patrones de poblamiento y de la organización ceremonial de Zinacantan", en: Los Zinacantecos, (Vogt, ed.) México, Instituto Nacional Indigenista, pp. 63-87.

WASSERSTROM, Robert. 1989. Clase y Sociedad en el Centro de Chiapas. México, Fondo de Cultura Económica.

WILLAIME. Jean Paul. 1994. Dinamique religieuse et modernité (mcs.), Ecole Pratique des Hautes Etudes. Societé Droit et Religion en Europe, StransburgoParis.

WOLF, Eric. 1977. Una Tipologia del Campesinado Latinoamericano. Buenos Aires, Ed. Nueva Visión.

1986. Pueblos y Culturas de Mesoamérica. México, Ed Era. 
WILLIAMS Garcia, Roberto. 1957."Un mito y los mazatecas", en: Tlatoani, Segunda Epoca, Núm. 11, p. 42.

YOPIHUA Palacios, Agustin. 1992. Los Mecanismos de Actualización del Náhuatl de Soledad Atzompa. Xalapa, Universidad Veracruzana (tesis de licenciatura en antropologia).

ZANTWIJK, R.A.M Van. 1974. Los Servidores de los Santos. México, Instituto Nacional Indigenista. 